JOSÉ PEDRO DE CAMARGO RODRIGUES DE SOUZA

\title{
APONTAMENTOS SOBRE A TRANSCENDÊNCIA DO RECURSO DE REVISTA
}

\author{
DisSERTAÇão DE MeSTRAdo
}

Orientador: Prof. Dr. eStêvão Mallet

FACULDADE DE DIREITO DA USP

SÃO PAULO

2011 
JOSÉ PEDRO DE CAMARGO RODRIGUES DE SOUZA

\section{APONTAMENTOS SOBRE A TRANSCENDÊNCIA DO RECURSO DE REVISTA}

Dissertação de Mestrado apresentada à Banca Examinadora da Faculdade de Direito da Universidade de São Paulo, como exigência parcial para a obtenção do título de Mestre em Direito, sob orientação do Prof. Dr. Estêvão Mallet.

FACULDADE DE DIREITO DA USP SÃO PAULO 
Banca Examinadora 


\section{RESUMO}

Este trabalho discute a transcendência, requisito específico de cabimento do recurso de revista trabalhista, instituído pela Medida Provisória n. ${ }^{\circ}$ 2226, de 05 de setembro de 2001.

Quase uma década depois, essa criação legislativa não surtiu qualquer efeito prático, porque dependente de regulamentação por parte do Tribunal Superior do Trabalho (TST), o qual, todavia, depois de vários estudos, inclina-se por descartar esse critério de admissibilidade, em face da evidente dificuldade de se conceituar o que é transcendência econômica, política, social e jurídica.

A celeuma envolvendo esse requisito recursal, no entanto, abriu oportunidade para se discutir um pouco o papel da Justiça do Trabalho e, particularmente, a atuação do TST, incumbido de julgar um número cada vez maior de recursos de revista, o que pode comprometer a credibilidade de sua missão.

O surgimento da transcendência, portanto, instiga a revisitar as origens do próprio recurso de revista, procurando-se identificar na herança histórica romana, ibérica e lusitana, como surgiram a recorribilidade extraordinária das decisões e a jurisprudência e de que maneira isso se transferiu para o Brasil. Examinam-se, também, o processo legislativo de criação desse requisito, as experiências similares e a influência estrangeira e aborda-se a constitucionalidade da transcendência à luz da jurisprudência do Supremo Tribunal Federal, que, desde 1999, não admite o uso de medida provisória para legislar direito processual.

A dificuldade de operacionalização desse pressuposto, fato declarado em entrevistas por alguns Ministros do TST e reconhecido pela última Comissão incumbida de estudá-lo, resultou na elaboração de anteprojeto de lei, alternativo à transcendência, que é revelado e comentado neste trabalho.

Porque, na maioria das vezes, o direito do trabalho envolve interesses de grupos de indivíduos e de categorias profissionais e econômicas, com reflexos em todo o mercado de trabalho, a uniformidade de sua aplicação e de sua interpretação continua necessária, mas não pode restringir-se ao TST; deve, antes, ser compartilhada com os Tribunais Regionais, obrigados à unificação de sua jurisprudência interna. São urgentes alterações no sistema recursal trabalhista, com a adoção de medidas, mais simples, objetivas e práticas, em sintonia com os propósitos de celeridade, qualidade, eficácia, segurança e justiça nos julgamentos.

Palavras-chaves: Herança Recursal Romana, Ibérica e Lusitana. Transcendência. Medida Provisória 2226/01. Constitucionalidade. Recurso de Revista. Interpretação e Aplicação Uniforme das Leis. Atualização do Sistema Recursal Trabalhista. 


\section{ABSTRACT}

This work discusses the principle of transcendence of appeals, a specific requirement for the admission of an appeal in a labor case instituted by the Provisional Presidential Decree no. 2226 of September 5, 2001.

After almost a decade, such legislative creation has not had any practical effect because it depends on regulation by the Superior Labor Court (TST) which, however, after several studies, tends to discard such criterion of admissibility in light of the clear difficulty of defining what is economic, political, social and legal transcendent.

Notwithstanding, the argumentation involving such requirement has opened the door to discussions about the role of Labor Courts and, in particular, the action of the TST that is responsible for adjudging an increasing number of appeals, which might compromise the credibility of its mission.

Hence, the rising of the principle of transcendence directs us to revisit the origins of the appeal in labor cases with the purpose of identifying in the Roman, Iberian and Portuguese historical heritage the source of the extraordinary appealability of decisions and the related case law and how this was transferred to Brazil. The legislative process of creation of such requirement is also examined, as well as similar experiences and foreign influences, and the constitutionality of the principle of transcendence in light of case law of the Brazilian Federal Supreme Court, seeing that it has not admitted the use of provisional presidential decrees to legislate on procedural right since 1999.

The difficult operationalization of such principle, as stated in interviews by some TST Justices and recognized by the last Commission incumbent on studying it, has resulted in the preparation of a bill alternative to the principle of transcendence that is disclosed and commented herein.

Considering that Labor Law, more often than not, involves interests of groups of individuals and professional and economic categories with reflexes in the labor market as a whole, it is required be consistently applied and constructed, albeit not restricted to the TST; it should, above all, be shared with the Regional Courts, compelling them to unify their internal case law. The changes in the labor appealing system are urgent, with the adoption of simpler, more objective and practical measures in accordance with the principles of celerity, quality, effectiveness, safety and justice in judgments.

Key words: Roman, Iberian and Portuguese Appeal Heritage. Principle of Transcendence. Provisional Presidential Decree no. 2226/01. Constitutionality. Appeal of Review. Uniform Construction and Application of Laws. Labor Appeal System Updating. 


\section{SUMÁRIO}

INTRODUÇÃO

.6

CAPÍTULO I. AS ORIGENS DO RECURSO DE REVISTA ……………………...........11

1.1. A Herança de Roma (recursos e jurisprudência) ........................................ 11

1.2. A Recorribilidade na Tradição Ibérica e Lusitana (Sopricação, Revista de Graça Especial e Especialíssima)........................................................27

1.3. O Recurso de Revista no Brasil ..............................................................50

CAPÍtULO II. O SURGIMENTO DA TRANSCENDÊNCIA NO RECURSO DE

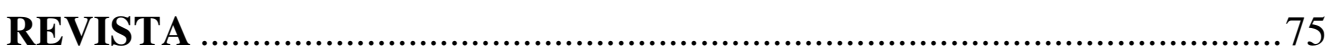

2.1. O Projeto de Lei 3267/2000 (tramitação e arquivamento) ..........................75

2.2. A Medida Provisória 2226, de 05 de setembro de 2001 e seu estágio

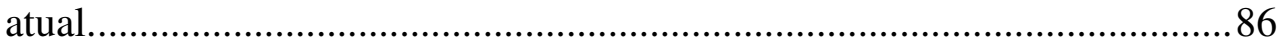

2.3. A Falta de Regulamentação da Transcendência pelo Tribunal Superior do Trabalho e a Opinião de alguns Ministros sobre essa matéria................95

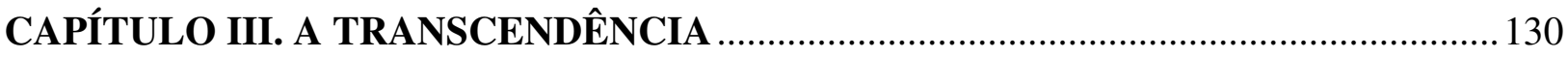

3.1. Pressuposto Recursal Específico ......................................................... 130

3.2. Pontos de Convergência: Relevância e Repercussão Geral....................... 145

3.3. O Devido Processo Legal e Processo do Trabalho ..................................... 174

CAPÍTULO IV. A CRISE DA TRANSCENDÊNCIA .................................................... 190

4.1. A constitucionalidade da Medida Provisória 2226/01 .............................. 190

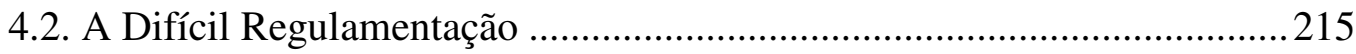

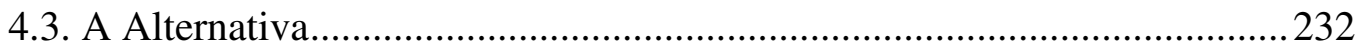

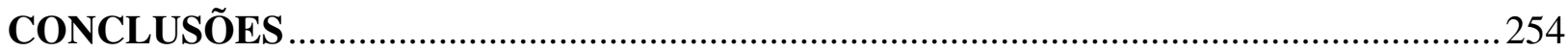

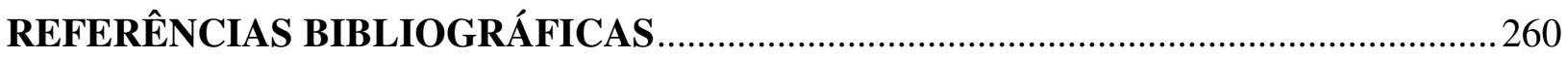




\section{INTRODUÇÃO}

Está para completar dez anos a edição da Medida Provisória 2226, de 5 de setembro de 2001, cujo art. $1^{\circ}$ acrescentou à Consolidação das Leis do Trabalho o art. 896-A, o qual erige como pressuposto específico do recurso de revista a prévia verificação "se a causa oferece transcendência com relação aos reflexos gerais de natureza econômica, política, social ou jurídica."

Conquanto esse requisito recursal tenha nascido sob o signo da relevância temática e da urgência, exigíveis por força do art. 62 da Constituição Federal, na prática, não surtiu efeito algum nos milhares de recursos de revistas que foram interpostos desde setembro de 2001, pois o "processamento da transcendência" foi relegado àquilo que o Tribunal Superior do Trabalho viesse a disciplinar no seu Regimento Interno (art. $2^{\circ}$ da MP), o que, também até hoje, não foi feito e tudo indica que não terá uma definição próxima.

Está-se, portanto, diante de situação legal absolutamente inusitada: a norma com força de lei está em plena vigência, chegou a ser, liminarmente, reputada constitucional pelo Supremo Tribunal Federal (ADI 2527-MC) e, no entanto, apesar de regra processual, vale dizer, de aplicação imediata, nenhum benefício conseguiu atingir.

À parte a gritaria de muitos e a perplexidade geral pela situação criada, há de se convir que a discussão em torno da transcendência do recurso de revista trouxe um fruto inesperado e benfazejo: agitou a sociedade como um todo, advogados e juízes em particular, concitando-os a repensar, em boa medida, o papel da Justiça do Trabalho, particularmente a missão unificadora jurisprudencial do Tribunal Superior do Trabalho.

Todos concordam que os Tribunais não conseguem dar conta dos julgamentos de forma segura, célere, eficaz, eficiente e harmônica, sedimentando a jurisprudência de maneira uniforme e sinalizando como deve ser a interpretação da legislação aplicável às relações de trabalho, para que se concretize a pacificação social, inatingível sem a segurança jurídica.

Lembre-se de que a Medida Provisória 2226/01 surgiu em plena efervescência da chamada reforma constitucional do Poder Judiciário, ainda não terminada, mas que já 
trouxe resultados concretos com a Emenda Constitucional 45/04, que, dentre outras medidas, reafirmou a importância e, por isso, ampliou a competência da Justiça do Trabalho.

A propósito, aí está a nova diretriz do inciso LXXVIII do art. $5^{\circ}$ da Constituição Federal, que dirige-se a todos, vale dizer, aos juízes, advogados e às partes.

E, ainda que não seja ignorada, está longe de surtir efeitos concretos porque a demora no término das ações implica vantagem econômica para quem deve, bastando considerar, só para se dar um exemplo, os ínfimos juros moratórios trabalhistas, à base da caderneta de poupança, notoriamente modestos, se comparados com os do art. 406 do Código Civil.

Inegável que, na linha de idéias que predominaram na reforma do Judiciário, o legislador civil já vem tentando restringir o mal uso dos apelos, implementando a repercussão geral para o recurso extraordinário, atribuindo efeito erga omnes e vinculante para determinadas decisões do E. STF, autorizando este último a editar Súmulas Vinculantes e, ainda, permitindo o trancamento de recursos logo no primeiro grau de jurisdição, se o julgamento estiver em consonância com jurisprudência do STF ou do STJ (arts. 518 e 557 do CPC).

No âmbito, porém, da Justiça do Trabalho a reforma ou modernização do processo do trabalho está longe de acompanhar os avanços constantes ocorridos no processo civil , por exemplo, com as Leis 11.232/05, 11.276/06, 11.418/06 (repercussão geral), 11.672/08 (processos repetitivos) e 12.322/10. Essa defasagem, em boa medida, decorre do fato de as normas processuais trabalhistas estarem inseridas no bojo da Consolidação das Leis do Trabalho (e, também, à lei de execuções fiscais), considerada intocável, o que não é correto sustentar, no mínimo em decorrência do passar do tempo e da modificação notória do mercado e das condições de trabalho.

Assim, afora a bem sucedida introdução do procedimento sumaríssimo (Lei 9957/00) e a criação (fracassada e desvirtuada) das Comissões de Conciliação Prévia (Lei 9958/00), a mais atual e impactante novidade no processo do trabalho continua sendo a transcendência como pressuposto do recurso de revista, o que, todavia (permita-se certa irreverência) "é sem nunca ter sido", pois existente apenas no papel. 
O surgimento da transcendência, portanto, instiga a revisitar as origens do próprio recurso de revista, que ostenta a chamada índole extraordinária, ou seja, tem finalidades específicas e limitações estritas de cabimento, sempre definidas em lei, pois ele se destina à busca da supremacia e da uniformidade de aplicação do direito do trabalho. Bem por isso, há de ser feita a necessária correlação desse tipo de apelo com princípios fundamentais do processo em geral, de matriz constitucional, particularmente o devido processo legal, e com os do processo do trabalho, com destaque para a celeridade, efetividade e instrumentalidade.

Paralelamente a essas discussões, outras afloram com muita força e dizem respeito a possível vício de iniciativa na criação de norma processual por meio de Medida Provisória e a de que maneira o Supremo Tribunal Federal enfrentou esse problema na Ação Direta de Inconstitucionalidade, que foi proposta pelo Conselho Federal da Ordem dos Advogados do Brasil.

E, porque a Medida Provisória 2226/01 chamou à cena os Ministros do Tribunal Superior do Trabalho, incumbidos que foram de regulamentar no seu Regimento Interno o processamento da transcendência, abre-se uma oportunidade ímpar de se averiguar como esses novos atores vêem o sistema recursal trabalhista e o requisito da transcendência e, ainda, que soluções alvitram.

Este trabalho, que se propõe chamar "Apontamentos sobre a Transcendência do Recurso de Revista”, caminha, no entanto, por terreno movediço, pois grande parte dele depende e gira em torno de criação legal que não foi implementada na prática, o que, em boa medida, dificulta sua análise, tornando-a, de outro lado, mais instigante e desafiadora.

E se diz apontamentos porque a intenção não é limitar o exame da transcendência do recurso de revista ao Direito Processual do Trabalho, mas procurar vê-la sob ângulos menos frequentes, como a História do Direito e a confluência com o Processo Civil e com institutos análogos, além de alguma jurisprudência constitucional por causa da polêmica origem da Medida Provisória 2226/01., o que exigiu pesquisas, entrevistas, análises e comparações, bem como implicou revelações e propostas.

O trabalho está dividido em quatro capítulos e uma conclusão. 
No primeiro, sem pretensões de esgotar o assunto sob o ponto de vista da História do Direito, buscam-se as origens do recurso de revista, aquele fio de meada essencial, ligado ao surgimento da recorribilidade ou da revogação da decisão, para tanto incursionando-se pela herança romana (appellatio e supplicatio) e pela tradição ibérica e lusitana (suplicação, revista de graça especial e de graça especialíssima) até chegar-se ao recurso de revista no Brasil, sempre procurando identificar algumas notas específicas desse tipo recursal (v.g. alçada, hipóteses de cabimento, prazo, depósito prévio, custas e isenção), com vistas à definição de sua finalidade, no correr dos tempos até hoje, e, ainda, seu caráter de excepcionalidade. A trajetória histórica demonstra a superação da admissibilidade arbitrária desse recurso (ao talante do rei) até o seu cabimento na estrita forma da lei e com julgamento por órgão judicial autônomo.

No segundo capítulo, discorre-se sobre o surgimento da transcendência, em si mesma, como pressuposto do recurso de revista, a partir da primeira tentativa de sua inclusão no sistema jurídico nacional, por parte do Poder Executivo, através do projeto de lei 3267 do ano de 2000 e, como, afinal, ele tramitou e foi arquivado. Em seguida põe-se à luz a gênese da Medida Provisória 2226, de 05 de setembro de 2001, e seu inconclusivo estágio atual de tramitação no Congresso Nacional. Discute-se, ainda, a falta de regulamentação do requisito da transcendência por parte do Tribunal Superior do Trabalho e revela-se o conteúdo de entrevistas com alguns Ministros da Corte sobre a alta litigiosidade trabalhista, o panorama recursal e sobre a transcendência do recurso de revista.

No terceiro capítulo fazem-se considerações sobre a conceituação da própria transcendência (indefinida e aberta), sua significação como pressuposto recursal específico, identificando-se, em seguida, pontos de convergência com a antiga relevância da questão federal e com a atual repercussão geral, estas ligadas ao recurso extraordinário constitucional, mostrando-se a influência do sistema norte-americano (writ of certiorari). Ao final, evoca-se o princípio do devido processo legal, formal e material, e se destacam características essenciais do Processo do Trabalho para se saber se não estariam sendo postas em xeque, nalguma medida, com a aplicação da transcendência, como se disse, conceito não definido em lei.

No quarto capítulo analisa-se a crise vivida pela transcendência, centrando-se na principal discussão, qual seja, a da constitucionalidade da Medida Provisória 2226/01, sob 
o prisma da jurisprudência do Supremo Tribunal Federal, que, desde 1999, não vê possibilidade de criação de norma processual por intermédio do art. 62 da Constituição Federal. Em seguida, tecem-se considerações sobre a dificuldade de regulamentação da transcendência por parte do Tribunal Superior do Trabalho, sobre a dissolução da primeira Comissão incumbida desse mister e, afinal, expõem-se as conclusões a que chegaram os membros da última, revelando-se o voto da maioria, externado pelo Ministro João Oreste Dalazen, assim como o voto vencido do Ministro Ives Gandra da Silva Martins Filho. Ao depois, porque não houve consenso no Tribunal Superior do Trabalho para a regulamentação da transcendência, como alternativa, apresenta-se o anteprojeto de lei elaborado pela última Comissão e comentam-se as propostas feitas, acrescentado-se outras.

Finalmente, apresentam-se algumas considerações conclusivas acerca desse pressuposto recursal trabalhista, justificando ou, não, a sua sobrevivência, inclusive no contexto de outras possíveis medidas, mais simples, objetivas, práticas e de eficácia imediata, culminando por indicar a bibliografia utilizada. 


\section{CAPÍTULO I. AS ORIGENS DO RECURSO DE REVISTA}

\subsection{A Herança de Roma (recursos e jurisprudência)}

Como é sabido e espera-se poder melhor explicitar neste trabalho, o recurso de revista, que, em última análise, busca obter terceiro e especial julgamento no processo, exibe peculiaridade que reside nas restritas hipóteses de seu uso, vale dizer, nos casos em que se identificam contrariedade manifesta à lei e divergência jurisprudencial.

De que maneira esse tipo de apelo foi sendo construído ao longo da história do direito romano, ibérico e lusitano, chegando até nós, alguma luz sobre a razão desse comportamento ou dessa escolha cultural, as transformações e as relações sociais que tiveram influência nesse processo, esta, enfim, é a proposta da abordagem inicial deste trabalho. ${ }^{1}$

De fato, na esteira dos ensinamentos de Luiz Carlos de Azevedo, se o direito exibe como característica essencial a estabilidade e a segurança (e, particularmente, assim deve ser o direito processual), não pode ficar alheio às alterações do meio social em que surge e para o qual se destina e isso faz parte da história da própria civilização e, de forma especial, da História do Direito.

Afinal, como adverte, "não há direito que de modo espontâneo nasça; muito ao revés, traz sempre consigo a bagagem que as civilizações precedentes proporcionaram e transmitiram."2

\footnotetext{
${ }^{1} \mathrm{Na}$ linha de idéias expostas por José Rogério Cruz e Tucci e Luiz Carlos de Azevedo (Lições de história do processo civil romano. São Paulo: Ed. Revista dos Tribunais, 2001. p. 20-24), quando justificam o estudo da história do direito: "oferecer ao Direito atual a compreensão de sua retrospectiva, esclarecendo as suas dúvidas e levantando, passo a passo, a estrutura do seu ordenamento, seus institutos mais perenes, suas bases de fundo e suas características de forma, até chegar à razão de ser do seu significado e conteúdo".

${ }^{2}$ AZEVEDO, Luiz Carlos de. Introdução à história do direito. São Paulo: Ed. Revista dos Tribunais, 2005. p. 17 e 36, nesta última em que é feita notável citação do Prof. Waldemar Ferreira: "Nenhum jurista pode dispensar o contingente do passado a fim de bem compreender as instituições jurídicas dos dias atuais. Ninguém é capaz de dar um passo à vanguarda, adiantando um, sem deixar o outro pé na retaguarda. Diferentemente não se realizam caminhadas."
} 
Desde logo, no entanto, faz-se ponderação necessária a propósito de se dedicarem algumas linhas a respeito da origem dos recursos, em geral, e, particularmente, do de revista: na verdade, como este trabalho não está ligado, especificamente, à área da História do Direito, não se busca uma ampla e exauriente investigação histórica desse instituto, mas privilegia-se, em primeiro lugar, a maneira pela qual, através dos tempos e dentro da tradição do nosso sistema jurídico romano e lusitano, como veio a nascer a idéia de reexame, de novo julgamento e de revogação das decisões; em segundo lugar, o caráter restrito, específico, "extraordinário" desse apelo, até os nossos dias, mormente no processo do trabalho.

Naquilo que essencial, será feito contato com a trajetória desse recurso ao longo do tempo, identificando o fio condutor histórico das hipóteses de recorribilidade e de alguns dos pressupostos recursais, desde a total discricionaridade no seu cabimento (a critério do Príncipe) até a vinculação legal, compatível com o devido processo legal.

E, ainda no que se refere aos antecedentes históricos da revista, tem-se presente a advertência feita por Estêvão Mallet, segundo o qual não se pode pretender exatidão matemática quanto à época do surgimento dos recursos de natureza extraordinária, em face da "lenta e gradual transformação dos institutos jurídicos", nada impedindo, porém, "que se exponha a linha evolutiva das figuras das quais deriva o recurso de revista hoje previsto na legislação processual do trabalho.", 3

Nessa perspectiva, portanto, há de se ter em conta que, nos primórdios de Roma, o direito e a religião estavam intimamente ligados, daí por que a jurisdição era atribuída ao rei que, "único depositário da potestas publica, reunia em sua mãos, por força do seu imperium além dos poderes militares e religiosos, poderes civis, legitimando-o a julgar, com o auxílio do colégio pontifical, em primeira e última instância”. 4

A pouco e pouco, com o evoluir da sociedade romana, principalmente com o incremento do comércio, à época preponderante fonte de riqueza, os litígios tornaram-se mais frequentes e complexos (tenha-se em conta a grande expansão dos domínios romanos e o contato com outros povos), o que redundou na criação de um corpo específico de

\footnotetext{
${ }^{3}$ MALLET, Estêvão. Do recurso de revista no processo do trabalho. São Paulo: LTr, 1995. p. 25.

${ }^{4}$ CRUZ E TUCCI, José Rogério. Perspectiva histórica do precedente judicial. 2003. Tese (Titular) Faculdade de Direito da Universidade, São Paulo. São Paulo, 2003. p. 31. No mesmo sentido, CRUZ E TUCCI, José Rogério; AZEVEDO, Luiz Carlos de. op. cit., p. 43.
} 
auxiliares do rei para a função jurisdicional, dela se alijando, paulatinamente, o corpo religioso.

É o fenômeno da laicização do direito e a paralela secularização da jurisprudência, conforme, detalhadamente, explica José Rogério Cruz e Tucci ${ }^{5}$, para o que muito concorreram a fixação escrita do ius civile, o surgimento das primeiras obras jurídicas, do pretor urbano e do peregrino, assim como a sistematização do direito, visto nas suas três faces (ius civile, ius honorarium e ius gentium), "cuja unidade permaneceu preservada por obra dos juristas"6

No sistema da ordo judiciorum privatorum, que compreende o período das legis actiones (até cerca do ano 114 a. C - ou 149-126 - , com o advento da Lex Aebutia) e o período formular (até 285-305 d. C, com Diocleciano), vale dizer, desde a Realeza, passando pela República, até o Império, ${ }^{7}$ não há como se cogitar da recorribilidade dos julgamentos, salvo exceções raras, que serão abaixo indicadas. ${ }^{8}$

Isto ocorria porque não existiam juizes públicos e, sim, privados (cidadãos escolhidos pelas partes ou indicados pelo pretor) e, ainda mais, porque eles não estavam em posição hierárquica, de modo a que a primeira decisão fosse reexaminada pela atuação de um segundo iudex, este, aliás, que não criava o direito, na medida em que adstrito à fórmula precedentemente detalhada pelo pretor. ${ }^{9}$

Mesmo antes da República, anota, agora, Moacyr Amaral Santos, à época das "legis actiones" também não havia recorribilidade em face das decisões civis e criminais, nestas últimas, porém, admitindo-se "a provocatio, que consistia na convocação dos comícios

${ }^{5}$ CRUZ E TUCCI, José Rogério. op. cit., p. 32.

${ }^{6}$ Id. Ibid., p. 35 e 37.

${ }^{7}$ Como lembram Moacyr Lobo da Costa (A revogação da sentença. São Paulo: Ícone, 1995. p. 19 e 55) e Vicente Greco Filho (Direito processual civil brasileiro. São Paulo: Saraiva, 1996. p. 286) houve interseção entre os períodos da ordo judiciorum privatorum e o da cognitio extra ordinem, de sorte que os sistemas conviveram por algum tempo, sem delimitações precisas e estanques. No mesmo sentido, CRUZ E TUCCI, José Rogério; AZEVEDO, Luiz Carlos de. op. cit., p. 39- 40.

${ }^{8}$ REZENDE FILHO, Gabriel José Rodrigues de. Curso de direito processual civil. 5. ed., São Paulo: Saraiva, 1957. p. 44-58, cujo Capítulo V traz notável síntese da evolução do direito processual, partindo do processo romano, com destaque para algumas peculiaridades das três fases (legis actiones, formulário e cognitio extraordinaria). Interessante destacar que uma das cinco ações da lei, a actio sacramenti, caracterizava-se pelo "fato dos litigantes serem obrigados a depositar em mão do pontífice certa importância em dinheiro, denominada sacramentum. O vencido, além do pagamento da condenação, perdia em favor dos sacrifícios públicos - sacra publica - a importância depositada." Aqui, talvez, a remota razão histórica para a exigência de depósitos prévios, que impregnou o direito lusitano e chegou até os nossos dias, seja na ação rescisória, seja, particularmente, nos recursos trabalhistas.

${ }^{9}$ CRUZ E TUCCI, José Rogério. op. cit., p. 36. 
populares, para pedir clemência. Igualmente irrecorrível continuaram as decisões no regime formulário, o que se justificava com considerar que o contrato judiciário, que se estabelecia pela litiscontestatio, obrigava as partes ao que fosse decidido."

Essa situação excepcional é lembrada por Wilson de Souza Campos Batalha, quando faz sinopse histórica dos recursos e invoca Caio Túlio Cícero para confirmar a provocatio nas decisões criminais que implicassem pena capital, ${ }^{11}$ o que também é confirmado por Marcello Caetano. ${ }^{12}$

Pois bem, a condenação gerava uma obrigação sui generis, ligada ao próprio julgamento e nele tinha sua força. Depois de esgotados os trinta dias para que o devedor, de forma espontânea, cumprisse obligatio iudicati, o credor retornava ao juiz pedindo-lhe que se iniciasse a actio iudicati para o cumprimento daquela obrigação, podendo a execução recair sobre a própria pessoa do devedor ou sobre seus os bens, se ele não contestasse. Se, no entanto, o devedor oferecesse impugnação, passando a discutir a existência ou a validade da primitiva decisão/obrigação judicial, prosseguia-se no julgamento da actio iudicati, antes prestando-se caução e ficando ciente o devedor de que atitude defensiva, considerada temerária, poderia implicar pagamento dobrado. ${ }^{13}$

E, arremata Moacyr Lobo da Costa:

O iudicium na actio iudicati destina-se a apurar se a sentença era ou não juridicamente válida, ou melhor, se havia sido pronunciado um perfeito julgamento, como disse Macro, "si quaeratur, judicatum sit, nec ne" (Dig. $49,8,1 \mathrm{pr})$.

É que o julgamento podia padecer de vícios que tornavam a sentença nula e portanto inválida. A sentença nula era considerada juridicamente inexistente.

Os diferentes motivos da nulidade da sentença, no regime do Ordo, eram atinentes, tão-somente, aos pressupostos processuais que o ordenamento exigia para que se pudesse constituir, desenvolver e concluir um processo com uma sentença válida.

Assinale-se, por outro lado, que, nesse período, os motivos de nulidade da sentença não diziam respeito, jamais, à intrínseca injustiça do julgado,

\footnotetext{
${ }^{10}$ SANTOS, Moacyr Amaral. Primeiras linhas de direito processual civil. São Paulo: Saraiva, 1990. p. 82.

${ }^{11}$ BATALHA, Wilson de Souza Campos. Tratado de direito judiciário do trabalho. São Paulo: LTr, 1977. p. 743.

${ }^{12}$ CAETANO, Marcello. História do direito português, Lisboa: Editorial Verbo, 1985. p. 68 e 71.

${ }^{13}$ COSTA, Moacyr Lobo da. op. cit., p. 13.
} 
à inobservância de preceitos do direito substancial, ou ao mérito da lide decidia. ${ }^{14}$

Aqui, portanto, uma importante distinção entre decisão nula, reputada inexistente, e decisão válida. Isto terá reflexos significativos nas hipóteses recursais e percorreu muitos séculos sendo aceita e, em certa medida, subsiste até os nossos dias. ${ }^{15}$.

Cada uma dessas decisões (nula ou válida) tem tratamento revogatório diferenciado: a primeira poderia ser impugnada a qualquer tempo, sem necessidade de apelar, pois não transitava em julgado; já a segunda, poderia ter seu mérito reexaminado e reformado através do recurso, cuja interposição impedia o trânsito em julgado.

Observou, ainda, Moacyr Lobo da Costa que esse princípio, consagrado no direito clássico, permaneceu incólume até o direito justinianeu, existindo no Digesto trecho, segundo o qual só se deve entender por

condenado aquele que o foi em processo regular por sentença válida, porque, se a sentença é nula por qualquer razão, deve-se dizer que não tem lugar o termo condenação; Dig. 42.1.4.6, Condemnatum accipere debemus eum, qui rite condemnatus est, ut sententia valeat; ... ${ }^{16}$.

Como se vê, a necessidade do cumprimento de determinados pressupostos processuais, de se seguirem certas regras postas (rite condemnatus), sob pena de nulidade da decisão, está a indicar que, por volta do século VI, o Direito Romano justinianeu, muito provavelmente, já sedimentara aquilo que mais tarde se construiu como sendo o devido processo legal (procedimental, pelo menos).

E, por volta do século XIII, mutatis mutandis, conforme destaca Luiz Carlos de Azevedo, na mesma linha de idéias, foi afirmada e construída no Direito Canônico a

\footnotetext{
${ }^{14}$ COSTA, Moacyr Lobo da. op. cit.

${ }^{15}$ É o que acontece, por exemplo, com a falta de citação, que implica a revelia do réu. Desde os romanos, perpassando-se pela tradição lusitana até os tempos atuais, esse defeito sempre foi considerado tão grave, marcante e tão inaceitável, que poderia ser alegado a qualquer tempo e modo, não necessariamente por meio de apelação nem por ação rescisória. A propósito, confira-se o que diz Estêvão Mallet (in Prática de direito do trabalho. São Paulo: LTr, 2008. p. 250), valendo-se de doutrina clássica portuguesa (Almeida e Souza), de Liebman e de significativo julgamento do Pleno do STF (RE 97589, Rel. Min. Moreira Alves, DJU. 03.06.83).

${ }^{16}$ COSTA, Moacyr Lobo da. op. cit., p. 19 e 68.
} 
“importância e relevância do processo, 'quod autem nullus sine iudiciario ordine damnari valeat' (Decreto 2.2.1)". ${ }^{17}$

De qualquer sorte, porém, não pode ser desconsiderada a advertência que faz Vicente Greco Filho, ${ }^{18}$ segundo o qual esses meios de impugnação das decisões, "como a intercessio, a infitiatio, a revocatio in duplum, a restitutio in integrum, não eram recursos, mas novas ações ou meios políticos de proteção dos direitos individuais...", vale dizer, meios exógenos, fundamentalmente porque não se inseriam na mesma ação em que foi proferida a decisão contestada, como é o caso da appellatio. ${ }^{19}$

De fato, a appellatio passará a existir como meio de impugnação das decisões válidas sob o sistema do procedimento extra ordinem, quando funcionários e magistrados públicos vieram a atuar como delegados do poder do Imperador, processando e julgando as lides; no novo sistema deixa de existir a fase in iure (perante o pretor, que definia a direito aplicável), seguida da apud iudicem (este que sentenciava, em nome do povo romano, daí a inapelabilidade). ${ }^{20}$ Tudo passou a se concentrar na figura de um só magistrado, que agia por delegação do poder imperial. Esse novo sistema vigorou a partir do Principado de Augusto e, definitivamente, sob o Império. ${ }^{21}$

José Rogério Cruz e Tucci e Luiz Carlos de Azevedo, quando tratam da appellatio ${ }^{22}$ e valendo-se das lições de Orestano, sustentam que a apelação "jamais penetra na estrutura do processo formular". Ela nasce como uma "extensão, imprópria e arbitrária, da regra permissiva da impugnação originada pela praxe do novo sistema processual, ou seja, como uma extensão do princípio da recorribilidade das cognitiones. ${ }^{23}$

Como se viu antes, o iudex, julgava em nome do povo sob o sistema do ordo, mas, a partir do Principado, com o fortalecimento do poder central, único detentor da soberania (auctoritas), o juiz passou a decidir em nome desse último, por delegação, daí a possibilidade de revisão das decisões, exatamente, por quem havia delegado essas

\footnotetext{
${ }^{17}$ AZEVEDO, Luiz Carlos de. Introdução à história do direito. São Paulo: Ed. Revista dos Tribunais, 2005. p. 116.

${ }^{18}$ GRECO FILHO, Vicente, op. cit., p. 287.

${ }^{19}$ REZENDE FILHO, Gabriel José Rodrigues de. op. cit., p. 49-50, que alude às formas recursais do processo formulário (intercessio, revocatio in duplum e restitutio in integrum), ponderando, todavia, que a "apelação só apareceu mais tarde, ao tempo do Império".

${ }^{20}$ CRUZ E TUCCI, José Rogério. Jurisdição e poder. São Paulo: Saraiva, 1987. p. 31-40, quando alude ao surgimento da appellatio.

${ }^{21}$ SANTOS, Moacyr Amaral. op. cit., p. 83 e COSTA, Moacyr Lobo da. op. cit., p. 50.

${ }^{22}$ CRUZ E TUCCI, José Rogério; AZEVEDO, Luiz Carlos de. op. cit., p. 164-174.

${ }^{23}$ Id. Ibid., p. 164.
} 
atribuições, o que é lógico, portanto. A intenção não era garantir uma eficaz tutela dos interesses privados, mas usar a apelação como meio de afirmação e de ampliação das normas do direito imperial, tolhendo o arbítrio do pretor. ${ }^{24}$

Daí concluem os co-autores, há pouco citados, que o fundamento da instituição da apelação ao príncipe decorria do próprio poder imperial que, era o resultado não só “da justaposição dos poderes republicanos", mas vinha complementado "pelo prestígio pessoal e político de Augusto, bem como dos subsequentes governantes. Sendo assim, a ingerência do princeps no campo do direito não pode ser concebida como uma atuação de natureza jurisdicional propriamente dita, mas como uma intervenção política extraordinária, exclusiva do primus inter pares." ${ }^{25}$

A apelação, portanto, a partir dos primeiros séculos da era cristã, revela-se como instrumento político hábil para atingir a unificação do ordenamento jurídico em todos os recantos do vasto império romano e, também, é autêntico reflexo da concentração do poder absoluto nas mãos do imperador, tal como expôs José Rogério Cruz e Tucci no seu livro "Jurisdição e Poder", ${ }^{26}$ obra específica que descreve a trajetória dos recursos, desde Roma (appellatio e supplicatio) até o Império do Brasil.

A apelação passa a ser, então, o meio comum de insurgência "contra a injustiça substancial da sentença formalmente válida."27

O julgamento do recurso estava afeto, no início, ao praetor urbanus, depois ao praefectus urbi, sucedido pelo praefectus praetorio; cabia contra decisão definitiva e, excepcionalmente, contra decisão interlocutória; apelavam as partes e o terceiro prejudicado; o primitivo órgão julgador exercia juízo de admissibilidade (recipere vel non); a "decisão que inadmitia o seu processamento, seja porque inexistente causa probabilis, seja porque considerada appellatio moratoria, deveria ser fundamentada e, por sua vez, também era recorrível". ${ }^{28}$

Se já tivesse sido iniciada a execução, não era admitido o recurso; admitido este, o juiz poderia exigir caução, devendo o interessado remeter os autos ao julgador de revisão,

\footnotetext{
${ }^{24}$ CRUZ E TUCCI, José Rogério. Jurisdição e poder, cit., p. 49.

${ }^{25}$ CRUZ E TUCCI, José Rogério; AZEVEDO, Luiz Carlos de. op. cit., p. 167.

${ }^{26}$ CRUZ E TUCCI, José Rogério. Jurisdição e poder, cit., p. 31. Esta obra específica é fundamental para a compreensão dos recursos de natureza extraordinária, a partir da supplicatio romana.

${ }^{27}$ CRUZ E TUCCI, José Rogério; AZEVEDO, Luiz Carlos de. op. cit., p. 169.

${ }^{28}$ Id. Ibid., p. 171.
} 
ficando suspensa a execução; exigia-se, por fim, a presença das partes no julgamento, sob pena de deserção; era, então, analisada a apelação, com possibilidade de provas e de debates orais. Se modificado o primitivo julgamento, "a nova decisão substituía a anterior, devendo a parte sucumbente arcar com as despesas, além de sofrer uma sanção de natureza processual consistente na perda do valor caucionado ao ensejo da interposição da appellatio". ${ }^{29}$

Importante, também, fazer referência à appellatio more consultationis pelas singularidades que ostentava, algumas das quais pode-se dizer que sobreviveram até esta parte.

Tratava-se de insurgência contra decisões de juízes de segundo grau, dirigindo-se as partes ao tribunal imperial (sacrum auditorium); não havia possibilidade de o recurso ser recebido ou, não, vale dizer, desde que observado o prazo, valor de alçada e possibilidade de recurso, não poderia o juízo a quo impedir o acesso à instância ad quem. Neste recurso não poderia ser feito novo pedido nem exposta nova causa de pedir. ${ }^{30}$

A parte deveria, necessariamente, apresentar os fundamentos da sua irresignação (refutatoriae preces) ${ }^{31}$ e pedir ao juízo recorrido que expusesse as razões pelas quais havia julgado desta ou daquela forma (opinio).

\section{A longa trajetória histórica da appellatio fez com que seu uso prático se} ampliasse também para os casos de nulidade (o que contrariaria, em princípio, a idéia de inexistência), malgrado, permanecesse a regra segundo a qual não seria necessário apelar de sentença nula porque ela não tinha validade.

Essa invalidade da decisão está mencionada no Digesto, 49,1, 19: a sentença que for proferida contra o rigor do direito não pode valer e, portanto, sem necessidade de

\footnotetext{
${ }^{29}$ CRUZ E TUCCI, José Rogério; AZEVEDO, Luiz Carlos de. op. cit.

${ }^{30}$ Claro parece que o recurso não poderia inovar, ou seja, a matéria discutida haveria de ter sido tratada no juízo a quo, o que constituiu o cerne do prequestionamento, há muito exigido pela Súmula 356/STF e pela Súmula 297/TST.

${ }^{31}$ Desde o século IV, portanto, considerava-se que impugnação dos fundamentos da decisão recorrida era da essência do recurso subsequente, sendo nesse sentido a Súmula 422/TST, verbis: RECURSO. APELO QUE NÃO ATACA OS FUNDAMENTOS DA DECISÃO RECORRIDA. NÃO CONHECIMENTO. ART. 514, II, do CPC (conversão da Orientação Jurisprudencial no 90 da SBDI-2) - Res. 137/2005, DJ 22, 23 e 24.08.2005 Não se conhece de recurso para o TST, pela ausência do requisito de admissibilidade inscrito no art. 514, II, do CPC, quando as razões do recorrente não impugnam os fundamentos da decisão recorrida, nos termos em que fora proposta. (ex-OJ n ${ }^{\circ} 90$ da SBDI-2 - inserida em 27.05.2002).
} 
apelação, pode ser renovado o litígio. E deve considerar-se sentença contrária ao direito aquela que for proferida contra as leis, senátus-consulto ou constituição imperial. ${ }^{32}$.

O erro manifesto na aplicação do direito (vale dizer, de índole substancial), portanto, veio a ser equiparado às outras causas de nulidade (inexistência) da sentença, ligadas à formação do processo, tal como explica Moacyr Lobo da Costa:

A sentença proferida contra ius constitutionis passou, também a ser considerada non ulla, isto é, nenhuma.

A introdução deste novo critério ampliou a esfera da nulidade das sentenças, alçando a inobservância das normas editadas pelos imperadores ao nível das regras processuais sobre a validade dos julgamentos, que o espírito formalista do direito romano clássico considerava como garantia do cidadão para perfeita distribuição da justiça. Estrutura-se, então, a fundamental distinção entre ius litigatoris e ius constitutionis, que vai servir de base para aplicação prática do princípio, em razão da impugnabilidade da sentença. ${ }^{33}$

Neste passo, ainda que au vol d'oiseau, imprescindível fazer um pequeno parêntese e mencionar a restitutio in integrum, em face de ter ela encontrado ponto de contato com a apelação.

Originariamente, a restituição, que já era conhecida no primeiro século anterior à nossa era, representou a "progressiva vitória da equidade sobre o rigor do direito". 34

A restituição é fruto de paulatina construção dos magistrados dotados de imperium (pretores, cônsules, governadores de províncias), a partir de experiência vivida fora de Roma e para lá trazida, sob o sistema da ordo judiciorum privatorum, visando a auxiliar, suprir ou corrigir o rigor e formalismo do direito civil, em detrimento da boa-fé, para tanto restaurando a situação jurídica anterior, mesmo que tivesse sido validamente constituída.

Tratava-se de auxílio extraordinário porque o pretor dava solução concreta para o caso (via de regra, desfazendo o ato que acarretava a lesão, dando um salto para trás no

\footnotetext{
${ }^{32}$ COSTA, Moacyr Lobo da. op. cit., p. 21 e 70.

${ }^{33}$ Id. Ibid., p. 69. Esta concepção do direito romano parece ter nítida relação com a hipótese de recorribilidade dos recursos de natureza extraordinária, quando tratam da violação de preceito de lei, sob o ponto de vista geral. Vide, também, CRUZ E TUCCI, José Rogério; AZEVEDO, Luiz Carlos de. op. cit., p. 181, ao tratar da supplicatio.

${ }^{34}$ Id. Ibid., p. 75.
} 
tempo, por ficção, como se ele não tivesse existido) e, também, porque não havia disponibilidade de uso dos meios ordinários para remediar a situação ocorrida.

As principais causas de concessão da restituição criadas pelos pretores, afinal, foram reunidas no Edito Perpétuo, sob o Imperador Adriano (século II d. C.), ampliando-se aquele primitivo fundamento da absentia rei publicae causa e da minoridade de 25 anos. ${ }^{35}$

Já sob Justiniano, no século VI d.C, reduziram-se a duas as hipóteses, pela absorção das outras "pelo sistema de ações do regime imperial da extraordinária cognitio." 36

No Principado, todavia, ocorreu o que Moacyr Lobo da Costa caracterizou como "recíproca inserção da appellatio na r.i.i. e desta na appellatio". Como se viu antes, a primeira passou a cumprir a função de remédio comum e disponível contra a injustiça perpetrada nas decisões.

Já a restitutio in integrum, deferida pelo pretor, fundamentalmente baseada na equidade e na boa-fé, por se tratar de auxílio extraordinário, só cabível naqueles casos capitulados, afinal, no Edito Perpétuo, estando, agora, sujeita à reexame pelo praefectus urbi ou pelo imperador, tudo isso acabou colocando em desvantagem a função originária da restituição. ${ }^{37}$

Todavia, continuou a exercer função subsidiária integrativa e corretiva, como antes, isto é, para abrandar os rigores processuais, que impedissem a própria apelação.

É o que se dava na restituição do prazo recursal, que, malgrado improrrogável, haveria de ser renovado em favor da parte que tivesse estado ausente rei publicae causa.

Se estivesse envolvido e fosse prejudicado menor de 25 anos, cujo procurador deixou de apelar, a restituição cumpria papel mais amplo, pois desconstituía a própria sentença. $^{38}$

\footnotetext{
${ }^{35}$ CRUZ E TUCCI, José Rogério; AZEVEDO, Luiz Carlos de. op. cit., p. 35.

${ }^{36}$ COSTA, Moacyr Lobo da. op. cit., p. 50.

${ }^{37}$ Id. Ibid., p. 57.

${ }^{38}$ Id. Ibid., p. 58, cumprindo destacar o seguinte trecho: "Uma das nervaturas essenciais do instituto da appellatio" é a inderrogabilidade do prazo recursal, "para que esse remédio não degenere em instrumento de arbítrio e de desordem". Este princípio da legislação imperial consolida-se e vai se espraiar para todos os outros recursos.
} 
Terminado o parêntese sobre a restituição, retoma-se a linha expositiva anterior sobre a apelação.

Cabe, então, a seguinte síntese: a existência de um corpo profissional e hierarquizado de magistrados (o praetor, em primeiro lugar ou grau, e o praefectus urbi, em segundo) e o reconhecimento da appellatio como instrumento ordinário (comum), disponibilizado ao vencido para pedir o reexame da decisão, que ele considerava injusta (não aquela nula, como antes se disse), representam, enfim, concentração de poder nas mãos do Imperador (ou de seus delegados), seja na criação da lei, seja na respectiva interpretação, tudo isso, é fenômeno que se consolida a partir de Diocleciano e Constantino. ${ }^{39}$

Certo é que, a partir de constituição imperial do ano 331 d. C., Constantino proibiu que fosse manejada apelação contra decisões proferidas pelo Prefeito do Pretório ${ }^{40}$,

que se tornou o verdadeiro substituto do imperador no terreno jurisdicional, e que, por sua dignidade e sabedoria, não haveria de julgar de outro modo como o faria o próprio imperador (Dig. 1.11.1 $\S 1^{\circ}$ ). Ao vencido e inconformado com a sentença do prefeito do Pretório, contra a qual não era permitido apelar, foi concedida a faculdade de se dirigir ao imperador por meio da supplicatio, instituto de ordem imperial, com natureza de recurso extraordinário, criado, ao que parece, pelos imperadores Teodósio e Valentiniano, em 439, na constituição recolhida no Código Justiniano, Livro 7, Título 42, ... ${ }^{41}$

A natureza extraordinária da supplicatio quer significar que se trata de recurso excepcional, incomum e restrito, cujo

fundamento político residia no poder de graça exclusivo do imperador. A exemplo de todos os requerimentos encaminhados ao tribunal imperial (consistorium principis), como, v.g., a appellatio more consultationis, as razões da supplicatio deveriam ser escritas e dirigidas à autoridade imperial. ${ }^{42}$

\footnotetext{
${ }^{39}$ COSTA, Moacyr Lobo da. op. cit., p. 51, 57 e 64. Estas marcas distintivas do poder jurisdicional se mantiveram, em boa medida, na tradição ocidental e, particularmente, na luso-brasileira.

${ }^{40}$ Aqui se incluem os outros magistrados superiores equivalentes (v.g. proconsules e comites provinciarum), conforme explicam CRUZ E TUCCI, José Rogério; AZEVEDO, Luiz Carlos de. op. cit., p. 176.

${ }^{41}$ COSTA, Moacyr Lobo da. op. cit., p. 59 e, também, CRUZ E TUCCI, José Rogério; AZEVEDO, Luiz Carlos de. op. cit., p. 178, os quais discutem a época do surgimento da supplicatio e, invocando Litewski e Purpura, consideram-na já existente no reinado de Constantino.

${ }^{42}$ CRUZ E TUCCI, José Rogério; AZEVEDO, Luiz Carlos de. op. cit., p. 179. Trata-se de concepção que também norteará (os recursos de) as revistas de "graça especial" e de "graça especialíssima", como se verá, oportunamente. Vide, também, de José Rogério Cruz e Tucci, a já citada e específica obra Jurisdição e poder, cit., às páginas 58 usque 81, o item 3 do Capítulo II, Supplicatio como recurso autônomo.
} 
O escopo deste recurso era obter do Imperador uma ordem de reexame daquela matéria que foi antes julgada pelo magistrado de segundo grau, seja ela de fato ou de direito, vale dizer, abrangia toda a controvérsia trazida a juízo, daí por que a supplicatio só poderia ser apresentada uma única vez.

Neste recurso específico, o Imperador se restringia à análise do seu cabimento, atribuindo ao juízo a quo (nos primórdios, desde que outro fosse o Prefeito do Pretório, o que foi posteriormente alterado ${ }^{43}$ ) o rejulgamento do caso, o qual, "pronunciava, então, um novo julgamento que confirmava a precedente sentença, sem imposição de qualquer sanção ao litigante que havia interposto a supplicatio ou a rescindia - procedendo a verdadeira retratação -, sempre havendo, como salientado, a possibilidade de reformatio in pejus, ou, até mesmo, de uma decisão ultra petita". ${ }^{44}$

No período justinianeu, por metonímia, a suplicação passa a ser chamada pelo nome de retratação (i.e. pela identificação do primordial efeito do recurso - efeito/causa).

Paralelamente, como usavam-se os princípios da apelação, logo a suplicação perdeu seu caráter excepcional, até que uma norma do ano 529, visando a coibir o prolongamento do processo, passa a restringir o uso da suplicação/retratação, deixando, então, de se aguardar, inclusive, a mudança do Prefeito do Pretório, sendo, desde logo oferecido o recurso, e, ainda, só existindo o efeito suspensivo caso fosse prestada caução. Vejam-se os termos da síntese feita pelos Professores Luiz Carlos de Azevedo e José Rogério Cruz e Tucci:

\begin{abstract}
Acrescente-se, por fim, que a discrepância estrutural, tão acentuada em momento anterior, entre a appellatio e a supplicatio, vai desaparecendo, posto que agora ambas vêm muitas vezes tratadas de modo quase uniforme pelas mesmas normas. Assim, a $N$. 115.1 (a.542), relativa à retroatividade da lei no tempo, preceituava que o novo julgamento a ser proferido em grau de apelação ou de supplicatio devia levar em consideração as leis que vigoravam à época da prolação da sentença recorrida. ${ }^{45}$
\end{abstract}

\footnotetext{
${ }^{43}$ CRUZ E TUCCI, José Rogério. Jurisdição e poder, cit., p. 77.

${ }^{44}$ CRUZ E TUCCI, José Rogério; AZEVEDO, Luiz Carlos de. op. cit., p. 184.

${ }^{45}$ Id. Ibid., p. 188.
} 
De se lembrar, finalmente, que as decisões do Praefectus por ele mesmo poderiam ser, excepcionalmente, objeto de retratação ou revisão (o que era proibido aos demais juizes).

Os Juízes poderiam admitir a restituição contra seus julgamentos (aqui o reforço da idéia de equidade), na hipótese de cometimento de erro ou de ter existido engano causado pelo adversário. $^{46}$

Reiterando a intenção de buscar aquele fio de meada histórico que veio a influir na construção do recurso de revista, também é imperioso mencionar, ainda que na sua síntese, como é que a jurisprudência (nas modalidades persuasiva ou vinculante) tomou posição de relevo no direito romano e de que maneira isso chegou até os tempos atuais.

Tal como explicado logo no início, considerada a experiência romana, só tem sentido cogitar da formação de precedente jurisprudencial a partir da gradativa separação entre o direito (ius) e a religião (fas), quando o primeiro adquiriu a preponderante forma escrita, quando consolidaram-se esquemas jurídicos abstratos (mesmo que em casos concretos), quando foi instituído um corpo de magistrados públicos e, ainda, pela repercussão da atuação criadora dos pretores, em especial no trato das questões que afloravam pelo contato com os povos conquistados, para os quais o rigor do ius civile romano não poderia ter aplicação estrita e seriam necessárias adaptações, daí surgindo o ius honorarium, "para auxiliar, suprir ou corrigir o direito civil, em razão do interesse público". 47

Assim, no sistema do ordo judiciorum privatorum, por volta do último século antes da era cristã, passou a ter importância maior a própria fórmula emanada do pretor, de modo que ela pudesse ser invocada para casos futuros semelhantes, também tendo sido levada em conta a opinião de juristas.

E Caio Túlio Cícero (Rethorica ad Herennium), preocupado com contradições de julgamentos em casos análogos, destaca a importância da invocação de precedentes judiciais (exemplum), cuja maior eficácia estaria ligada à similitude dos casos, à mesma época do julgamento e ao prestígio e à autoridade do prolator. Essa citação visava a

\footnotetext{
${ }^{46}$ COSTA, Moacyr Lobo da. op. cit.,p. 60-61.

${ }^{47}$ CRUZ E TUCCI, José Rogério. Perspectiva histórica do precedente judicial, cit., p. 37.
} 
ajudar a formação da convicção do juiz, o qual nem sempre tinha conhecimento jurídico (cidadão escolhido). ${ }^{48}$

Já no albor da era cristã, sob Augusto, a partir da reorganização do sistema processual (das legis actiones para o per formulas, até o predomínio da cognitio extra ordinem), a jurisdição veio a ser exercida pelo magistrado público, hierarquizado, passando, porém, a ter grande influência a última decisão do princeps ou sua manifestação em caso a ele submetido mediante consulta do juiz ou da parte.

Assim, essas constituições imperiais haveriam de ser acatadas, seja para o caso concreto, seja como "exemplo" futuro, segundo os ensinamentos de Gaio e Ulpiniano ${ }^{49}$. "E, por essa razão, atribui-se valor aos decreta, aos rescripta e às aepistolae como precedentes judiciais, porque fundados na auctoritas do órgão que as proferia, sendo certo que, em tal período, cunha-se a famosa máxima: "quod principi placuit legis habet valorem." 50

E, tal como assevera José Rogério Cruz e Tucci, não se poderia extrair dessas decisões do príncipe eficácia vinculante equiparável à da lei, mas delas seria possível inferir o caráter persuasivo do precedente uniforme e constante, tal como, de modo expresso, veio a ser aceito à época do Imperador Septímio Severo (século III). ${ }^{51}$

Quando se tratasse de pareceres jurídicos dos grandes juristas, que gozavam do ius respondendi, por força de delegação direta da autoridade do príncipe, e desfrutavam de incomum prestígio, podendo constituir o direito ${ }^{52}$, também tinham vinculação ao caso concreto, sem, todavia, efeito erga omnes, porque, segundo Gaio,

se houvesse colidência de pontos de vista acerca de alguma tese jurídica, o juiz da causa tinha a liberdade de julgar nos limites de um dos pareceres, sendo certo que não estava autorizado a proferir decisão lastreada em novo fundamento. ${ }^{53}$

\footnotetext{
${ }^{48}$ CRUZ E TUCCI, José Rogério. Perspectiva histórica do precedente judicial, cit., p. $48-49$.

${ }^{49}$ Id. Ibid., p. 56.

${ }^{50}$ Id. Ibid., p. 57.

${ }^{51}$ Id. Ibid., p. 61.

${ }^{52}$ AZEVEDO, Luiz Carlos de. op. cit., p. 67.

${ }^{53}$ CRUZ E TUCCI, José Rogério. Perspectiva histórica do precedente judicial, cit., p. 64.
} 
Terminado o Principado (235 a. D) e superada a anarquia militar, com Diocleciano (294 a. D.) houve reformas que visaram identificar a certeza do direito aplicável e, também, controle direto e efetivo dos julgamentos, como, por exemplo, os códigos Gregoriano e Hermogeniano, que continham transcrição de precedentes, desde Adriano.

Sob Constantino, porém, que justificava seu poder absoluto na vontade de Deus, houve maior concentração do poder jurisdicional na pessoa do Imperador.

Nesse novo contexto, a jurisprudência perde um pouco daquela criatividade do período clássico anterior e as fontes de produção do direito tendem a se restringir às leis gerais imperiais.

Em boa medida, portanto, essa centralização de poder, também refletiu-se na jurisprudência, de sorte que os precedentes (rescripta), que não estivessem de acordo com o direito imperial (contra ius), não poderiam ser utilizados, devendo prevalecer a interpretação da lei que viesse a ser feita pelo Imperador, legislador exclusivo, mas que também era seu único intérprete. Isso, não obstante, implicou que a literatura jurídica clássica gozasse de efeito normativo geral, desde que não fosse contrária às constituição imperiais mais recentes. ${ }^{54}$

Em face, porém, do já formado grande número de precedentes e da múltipla legislação do império, surge o problema da autenticidade dos textos invocados perante os tribunais.

Assim, para evitar uso equivocado ou, até, indevido, esse problema foi solucionado com a denominada "Lei das citações”, promulgada por Teodósio II e Valentiniano:

apenas gozariam de auctoritas nos tribunais as obras de cinco grandes juristas: Papiniano, Paulo, Gaio, Ulpiano e Modestino. Na hipótese de terem manifestado opinião diferente sobre um determinado assunto, valeria o ponto de vista da maioria; havendo empate, deveria prevalecer a tese de Papiniano. Nesse caso, não tendo este emitido opinião, o juiz então estaria livre para decidir a causa segundo a sua própria convicção. ${ }^{55}$

A partir dessa lei, conclui José Rogério Cruz e Tucci, as opiniões desses juristas clássicos não tinham (como antes), apenas, um viés persuasivo voltado aos julgadores

\footnotetext{
${ }^{54}$ CRUZ E TUCCI, José Rogério. Perspectiva histórica do precedente judicial, cit., p. 69-74.

${ }^{55}$ Id. Ibid., p. 77.
} 
(reflexo da autoridade e prestígio da jurisprudência clássica), mas "passam a ter um rígido cunho normativo, sancionado expressamente por uma lex imperial de âmbito geral". ${ }^{56}$

Certo é que o conflito, antes mais latente, entre a jurisprudência (iura) e as leis (leges), ficava mais exacerbado nesses momentos históricos em que se impunha a hegemonia do poder central, daí o Código Teodosiano (438), ao mesmo tempo em que reafirmava a aplicação da antes mencionada lei das citações, veio a insistir na ineficácia de precedentes contrários ao direito, pois os juízes deveriam seguir muito mais aquilo que estivesse prescrito no direito de forma pública ou geral. ${ }^{57}$

Essa mesma diretriz foi mantida e reafirmada por Justiniano, que retomando os fundamentos hierocráticos do poder imperial, iniciados com Constantino, insiste em que na sua pessoa concentrava-se a fonte das leis e da respectiva interpretação (imperator solus legislator et interpres iuris), com isso visando à unidade política e jurídica do império ${ }^{58}$.

Este intento veio a ser atingido, de forma significativa, com a codificação das leis e das opiniões dos juristas clássicos, feita no Digesto, desde que a última palavra, repita-se, ficasse com o Imperador.

Assim, o juiz haveria de non exemplis, sed legibus iudicandum est, de sorte que o precedente jurisprudencial fica em certa inferioridade perante a lei, mas haveria de ser absolutamente desconsiderado, caso fosse contrário à lei.

No entanto, se o Imperador tem a última palavra, os posicionamentos que, afinal, vierem a ser tomadas por ele terão força vinculante para o julgamento de casos futuros iguais, daí concluir José Rogério Cruz e Tucci

que os compiladores de Justiniano alcançaram um verdadeiro equilíbrio atinente ao binômio interpretação-aplicação da lei: o imperador e a sua lei se sobrepunham a todos. Os juízes estavam obrigados a ater-se àquela lei, mas para aplicá-la deveriam interpretá-la, considerando, inclusive a "autoridade das coisas constantemente julgadas de modo uniforme. ${ }^{59}$

\footnotetext{
${ }^{56}$ CRUZ E TUCCI, José Rogério. Perspectiva histórica do precedente judicial, cit., p. 79.

${ }^{57}$ Id. Ibid., p. 71 e 81.

${ }^{58} \mathrm{~A}$ preocupação com a unidade jurídica do Estado subjaz à justificativa dos recursos de natureza extraordinária, de modo a que não exista contradição fragrante ou aberrante entre as leis postas e os julgamentos proferidos.

${ }^{59}$ CRUZ E TUCCI, José Rogério. Perspectiva histórica do precedente judicial, cit., p. 86.
} 
A força persuasiva dos precedentes judiciais subsistirá no período posterior a Justiniano no império romano do Oriente, ao passo que no do Ocidente, com a fragmentação resultante das invasões bárbaras, essa influência ficará mais diluída. ${ }^{60}$

A interpretação da lei "com sentido universalmente vinculativo para futuro",61, todavia, será retomada e consagrada em Portugal, a partir do século XVI, deixando de ser atributo exclusivo do monarca, pois mais raramente presidia as sessões dos Tribunais Superiores, passando a ser mister da Casa da Suplicação, a qual, por convocação de seu Regedor, submetia o caso à deliberação dos desembargadores e, afinal, extraía "assento", 62 , que passava a ser jurisprudência obrigatória.

\subsection{A Recorribilidade na Tradição Ibérica e Lusitana (Sopricação, Revista de Graça Especial e Especialíssima)}

Na esteira das lições de Mário Júlio de Almeida Costa, depois de, praticamente, dois séculos de guerra de conquista (de 219 a.C. até 29 e 19 a.C., sob Augusto), os romanos conseguiram expulsar os cartagineses da península ibérica, tendo enfrentado, também, ponto de resistência específica de povos autóctones (v. g. os Lusitanos, com Viriato, os Cantábricos e Astures).

Segue-se, então, o período de romanização, não mais decorrente da mera convivência com as forças de ocupação, mas, agora, uma romanização "metódica e intensiva," para tanto concorrendo três elementos:

a assimilação lenta da cultura e da civilização dos Romanos pelos povos autóctones; a concessão da latinidade aos habitantes da Península, devida a Vespasiano (73/74 d. C.); e a concessão da cidadania romana aos súbditos do Império em geral, no tempo de Caracala (212 d. C.). Os dois últimos aspectos referem-se directamente à esfera jurídica. ${ }^{63}$

\footnotetext{
${ }^{60}$ CRUZ E TUCCI, José Rogério. Perspectiva histórica do precedente judicial, cit., p. 89.

${ }^{61}$ COSTA, Mário Júlio de Almeida. História do direito português. Coimbra: Almedina, 1992. p. 296-297.

${ }^{62}$ Tão importantes eram os assentos, que no prólogo das Ordenações Manuelinas, revogaram-se e cancelaram-se todas as outras ordenações, "salvo as que se acharem escritas no livrinho da Relação", como se constata nas ORDENAÇÕES Afonsinas. Lisboa: Ed. Fundação Calouste Gulbenkian, 1984. Livro 3, p. 17.

${ }^{63}$ COSTA, Mário Júlio de Almeida. op. cit., p. 87 e ss.
} 
Pondera, ainda, Mário Júlio de Almeida Costa que o direito romano encontrado e aplicado na Hispânia não equivalia, simplesmente, àquele praticado em Roma, mormente se observada e considerada a situação dos núcleos urbanos e dos rurais. Vejamos o que ele diz:

O sistema jurídico hispânico, nas vésperas das invasões germânicas, encontrava-se longe da perfeição do direito romano clássico. Vigorava o chamado direito romano vulgar ("Vulgarrecht"), que possuía uma estrutura menos complexa e cuja disciplina resultava da interferência de elementos autóctones. Era o reflexo do quadro social, econômico, cultural e jurídico da Península. ${ }^{64}$

Reafirma essa situação Marcello Caetano, segundo o qual o Direito Romano Clássico vinha a ser deformado pela adaptação às condições de cada uma das províncias e das cidades, não fosse também a própria decadência que já enfrentava o Império, àquela altura. Confira-se sua lição específica:

O direito culto de Roma, era, no século III, um sistema perfeito e subtil demais para as populações rudes das províncias. Havia, por isso, necessidade de lho explicar, de interpretar as leis ao sabor da compreensão e possibilidades naturais (de onde a interpretatio oficial), de transigir com certos desvios do rigor da letra e até com resistências locais ao direito importado. Assim se formou um Direito Romano vulgar em cada província, que foi a ponte de passagem entre o Direito próprio de Roma e o Direito nacional das nações neolatinas surgidas séculos depois, exactamente como as línguas neolatinas resultaram, não do latim clássico, mas do latim vulgar ou popular falado pelas populações das províncias. ${ }^{65}$

Em apertada síntese, mesmo com a concessão da latinidade e da cidadania romana (Caracala, 212 a. D), na península ibérica não se aplicava o direito romano em sua concepção originária, sequer ali existindo órgãos judiciais e juristas, que a ele dessem sustentabilidade e uniformidade.

O ambiente jurídico ibérico, portanto, apesar do fundo ou base romana, tinha forte influência de práticas populares e costumeiras ${ }^{66}$, o que coincidia com a bagagem

\footnotetext{
${ }^{64}$ COSTA, Mário Júlio de Almeida. op. cit., p. 96. Vide, também, a propósito, CRUZ E TUCCI, José Rogério. Jurisdição e poder, cit., p. 83-84.

${ }^{65}$ CAETANO, Marcello. op. cit., p. 86.

${ }^{66}$ COSTA, Moacyr Lobo da. op. cit., p. 84, que invoca Guilherme Braga da Cruz.
} 


\section{trazida pelos povos germânicos invasores, que também tinham tido contato próximo e fecundo com o império romano. ${ }^{67}$}

Sem, porém, entrar na cadente polêmica entre a "territorialidade" (critério abrangente e geográfico de aplicação das leis visigóticas, que teria prevalecido) e a "personalidade" (critério de aplicação, que levava em conta a simples intervenção de um visigodo na controvérsia), ${ }^{68}$ certo é que, em última análise, o direito visigótico constituiu, no dizer de Marcello Caetano (que invoca Manuel Paulo Merêa) repositório do direito romano vulgar ${ }^{69}$, daí sendo permitido inferir que, em boa medida, a espinha dorsal dos recursos do direito romano foi conservada e aplicada na península ibérica, guardadas as devidas precauções e adaptações locais.

Portanto, para os hispano-romanos aplicavam-se as leis visigodas, que vinham sendo consolidadas desde o Edito de Teodorico(460 a.D.), passando pelo Código de Eurico (476), pelo Breviário de Alarico (lex romana visigothorum, 506) até a total unificação com o Liber Judiciorum de Recesvindo (654), cuja edição vulgar foi conhecida como Forum Judicum e, Fuero Juzgo, posteriormente. ${ }^{70}$

Com a invasão árabe, a partir do século VIII, aquele quadro anterior não se alterou de forma radical, pois, malgrado fosse aplicado o Corão para os negócios que envolvessem os muçulmanos e moçárabes (aplicação pessoal do direito), para os demais habitantes (cristãos) subsistia a aplicação do direito romano-visigótico.

Anota Moacyr Lobo da Costa peculiaridade do direito muçulmano no que se refere à recorribilidade das decisões: elas poderiam ser revistas pelo próprio juiz ou por outro, não prevalecendo, portanto, a construção romana que foi feita em nome da justiça (verdade

\footnotetext{
${ }^{67}$ COSTA, Mário Júlio de Almeida. op. cit., p. 98 e 117. Vide, também, a propósito, Jurisdição e poder, cit., p. 87-94, obra de José Rogério Cruz e Tucci.

${ }^{68}$ Vide, a propósito, COSTA, Mário Júlio de Almeida, op. cit., p. 136 e CRUZ E TUCCI, José Rogério; AZEVEDO, Luiz Carlos de. Lições de história do processo civil lusitano. São Paulo: Ed. Revista dos Tribunais, 2009. p. 24.

${ }^{69}$ CAETANO, Marcello. op. cit., p. 86, em nota de rodapé.

${ }^{70}$ CRUZ E TUCCI, José Rogério; AZEVEDO, Luiz Carlos de. Lições de história do processo civil lusitano, cit., p. 31. Na obra Jurisdição e poder, cit.,, sempre citada, às páginas 93-94, José Rogério Cruz e Tucci sustenta que não foi Recesvinco, mas seu pai, Chindasvindo, que teria feito a unificação da legislação na península, acabando com a personalidade de aplicação das leis. Anota, ainda, este último autor, que sob o direito visigótico havia intervenção dos reis "nos litígios submetidos à cognição de magistrados inferiores" (p. 96). A supplicatio não é mencionada no Editum Theodorici nem no de Eurico, vindo mencionada, porém, no início do século VI, no Breviário de Alarico, como apelo ao Rei (p. 99).
} 
formal), da definitividade e da segurança jurídica (certeza do direito) ligadas à autoridade da coisa julgada. ${ }^{71}$

Para o islamismo mais importavam a equidade e a aplicação da religião na matéria a ser decidida.

É o que, em boa medida, também veio a ocorrer no Direito Canônico (que privilegia a busca da justiça e da verdade objetiva), por isso que também exibe peculiaridade na formação da coisa julgada, o que vem destacado por Luiz Carlos de Azevedo, quando alude às mais significativas contribuições ao mundo jurídico, que tiveram origem na Igreja Católica (v.g. ênfase na conciliação, importância do processo, termos necessariamente escritos, iniciativa do juiz na condução do processo, prova e assistência judiciária aos necessitados). ${ }^{72}$

De fato, nas causas de estado, nunca haverá trânsito em julgado, ficando aberta a possibilidade de revisão dos julgamentos e, dependendo da relevância do tema tratado, como, por exemplo, quando se discute anulação de casamento, impõe-se a necessidade de existir duas decisões no mesmo sentido ou coincidentes, para que se estabeleça a coisa julgada (duplex sententia conformis), o que, inclusive, até o começo do século XX, era muito mais rígido. ${ }^{73}$

Assim, nos primeiros séculos da luta de reconquista da península ibérica para tirá-la das mãos dos árabes ${ }^{74}$, aplicava-se o direito visigodo, o qual, por sua vez, como se disse, estava impregnado do direito romano vulgar e, particularmente, dos costumes locais, isso tudo malgrado a desorganização da vida urbana, exatamente por causa da guerra.

De fato, ainda que se considere o "ermamento", o vazio territorial entre a parte cristã da península e aquela ocupada pelos muçulmanos, as comunidades rurais, mesmo isoladas, “fizeram com que maior importância ganhassem as tradições jurídicas populares

\footnotetext{
${ }^{71}$ COSTA, Moacyr Lobo da. op. cit., p. 99.

${ }^{72}$ AZEVEDO, Luiz Carlos de. op. cit., p. 115-117.

${ }^{73}$ CRUZ E TUCCI, José Rogério; AZEVEDO, Luiz Carlos de. Lições de história do processo civil canônico. São Paulo: Ed. Revista dos Tribunais, 2001. p. 143.

${ }^{74}$ AZEVEDO, Luiz Carlos de. op. cit., p. 130-132. E, tal como anota José Rogério Cruz e Tucci (Jurisdição e poder, cit., p. 100), não se pode esquecer da influência da Igreja Católica a partir do momento em que adotada pelos visigodos, pois a "discricionariedade dos poderes monárquicos vem limitada pelo respeito aos dogmas da fé e da moral cristã. Era exatamente esse fundamento espiritual e não a simples detenção do poder de fato que legitimava a coroa - rex eris si recte facias, si no facias non eris, proclama Santo Isidoro." Daí a origem do recurso ao Bispo, que convocava o juiz que havia julgado errado, rejulgando com este (que podia retratar-se) ou sozinho, até remessa ao Rei, para confirmá-la (p. 102).
} 
locais, que assim representarão a continuidade do direito dos povos nativos do território português." 75

A luta de reconquista trouxe consigo não só o prestígio e influência decorrentes do esforço militar, mas, também, implicou concentração de poder nas mãos desses líderes, considerados verdadeiros salvadores da cristandade, como aconteceu a partir do reino de Astúrias, cujos reis, desde Afonso III, não eram considerados meros chefes de pessoas, mas expoentes da comunidade, porque tinham a "função de procurar o bem comum dos súditos, fazendo justiça, defendendo a fé, protegendo a Igreja, assegurando a paz pública interna e guerreando os inimigos externos."

E, por decorrência lógica, nessas prerrogativas reais estava compreendida a prestação da justiça.

No entanto, seja pelo alargamento dos domínios, seja pelo crescente número de pessoas que passaram a viver na Corte Real, inclusive do clero, e a impossibilidade de resolver todas as matérias trazidas perante o Rei, veio ele ser assistido por conselheiros nas questões militares, econômicas, religiosas e, também, judiciais, delegando esta função a alguns membros da corte que fossem de sua confiança para desenvolver esse mister. ${ }^{77}$

Mutatis mutandis, era o que já havia ocorrido em Roma, de forma definitiva a partir do Principado, agindo essas pessoas incumbidas de julgar sempre em nome do poder central e com a respectiva supervisão deste.

Essa centralização do poder na figura do Rei se fez presente nas oportunidades em que ele concedia os forais (fueros), à medida em se recuperavam as terras antes em mãos dos árabes, estabelecendo-se a autoridade local nos povoados, vilas e cidades.

É o que ocorreu, por exemplo, com a iniciativa de Afonso VIII, Rei de Castela, que, em 1190, outorgou o fuero da cidade Cuenca, o qual tinha a singularidade de prever querela contra o próprio julgador, caso este último agisse de forma injusta e desonesta ou, ainda, caso decidisse contra direito expresso no foral, conquanto ali não tenha ficado

\footnotetext{
${ }^{75}$ CAETANO, Marcello. op. cit., p. 120.

${ }^{76}$ Id. Ibid., p. 121.

${ }^{77}$ Id. Ibid., p. 124.
} 
explícito como se processaria esse recurso e a quem ele seria encaminhado, tal como anotou Moacyr Lobo da Costa. ${ }^{78}$

Algum tempo depois, com a fusão dos reinos de Castela e Leão, sob Fernando III (a. D. 1230), já avançada e quase ultimada a reconquista, vislumbrou El Rey a necessidade de uniformização (unidade) legislativa, não tendo mais sentido a fragmentação decorrente dos vários forais de cada cidade e, ainda, considerando os graves problemas que isso acarretava para a administração da justiça do reino.

Em grande medida, esse objetivo foi atingido com a tradução para o romance do Liber Judiciorum, que se tornou o Fuero Juzgo, malgrado a irresignação da nobreza, que não se conformava com crescente hegemonia do poder real.

Aqui, reiterados os propósitos deste capítulo (trajetória histórica do recurso de revista), imprescindível ter em conta outra singular ponderação feita Moacyr Lobo da Costa: no reino de Leão, o Liber Judiciorum era

\begin{abstract}
praticamente a única fonte de direito e suas normas escritas deviam ser observadas nos pleitos judiciais, especialmente no Tribunal do Livro, ao passo que, em Castela, o direito consuetudinário dos "Fueros" municipais gozava de preferência para a solução das questões, atendo-se os juízes mais aos usos locais que ao direito escrito e decidindo segundo seu próprio entendimento ou consoante os precedentes conhecidos das "façanhas" dadas em juízos anteriores. ${ }^{79}$
\end{abstract}

Como se vê, cruzam-se duas matrizes de aplicação do direito, que, então, pareciam antagônicas e inconciliáveis: de um lado, o predomínio do direito escrito e, de outro, a força da jurisprudência.

A idéia de unificação legislativa ou do direito (apesar da persistente oposição dos “fidalgos”) veio a ser continuada por Afonso X, que outorgou o Fuero del Libro ou Fuero

\footnotetext{
${ }^{78}$ COSTA, Moacyr Lobo da. op. cit., p. 101. De qualquer sorte, porém, essa idéia de dar importância e de buscar preservar o "direito posto" no foral, bem demonstra que, no sec. XII, sobrevivia o antes referido conceito romano do ius constitutionis, que, mais modernamente, emergirá na hipótese recursal extraordinária de "violação de lei".

${ }^{79}$ Id. Ibid., p. 103. Aqui também se identifica no sec. XIII a sobrevivência da experiência romana acerca dos precedentes judiciais como elemento importante para os julgamentos.
} 
Real (1254/1255), em cujo prólogo se vê a nítida intenção de impedir a prática de julgamentos por "façanhas" e sem base em fuero (norma escrita). ${ }^{80}$

Nesse foral se encontra, também, alusão a recurso dirigido diretamente ao rei, quando não mais coubesse apelação, objetivando reparar prejuízo causado pela decisão do juiz (v.g. para casos de suborno ou julgamento contra o direito), "em manifesta equiparação ao instituto romano da Supplicatio, por sua finalidade e efeitos",81 (...) "tal como a "Sopricação" do velho direito lusitano, que foi o ancestral remoto do agravo ordinário das Ordenações do Reino (Ordenações Afonsinas, L. III., T.109)”,

Este é exatamente o ponto de contato com os recursos de natureza extraordinária, dentre eles a revista, tal como será abordado, oportunamente.

Por iniciativa desse mesmo Rei, pouco depois, no final de 1263, começo de 1264 , vem ser editado o Fuero de las Leys ou Libro de las Leyes", que passou a ser conhecido, no século seguinte, como Sete Partidas ${ }^{83}$.

À sombra de D. Afonso X estava a respeitada figura do jurista Jácome Ruiz, também conhecido como Mestre Jácome das Leis, autor das "Flores de Derecho ou Flores de las leyes e dos Nueve tiempos de los pleitos”, no dizer de Mário Júlio de Almeida Costa, "compêndios relativos ao processo civil de inspiração romano-canónica, que tendia a substituir o sistema foraleiro e consuetudinário vigente, de raiz germânica. Aliás, a literatura processual do direito comum terá sido a que primeiro se repercutiu na Península e decisiva para a recepção prática desse sistema". ${ }^{84}$

\footnotetext{
${ }^{80} \mathrm{COSTA}$, Moacyr Lobo da. op. cit., p. 108, onde é transcrito trecho do prólogo do Fuero Real, do qual se extraem essas diretrizes sobre os julgamentos. Este mesmo autor, à p. 105, destaca a portentosa atuação legislativa de Afonso X, que, por isso, veio a ser cognominado o Justiniano Espanhol. No mesmo sentido é lição de Mário Júlio de Almeida Costa (op. cit., p. 232), que também dá ênfase à criação jurídica, à uniformização e à renovação do direito encetadas por Afonso X.

${ }^{81}$ COSTA, Moacyr Lobo da. op. cit., p. 111. Mais abaixo (p. 43) faz-se invocação do "Les Établissements de Saint Louis", rei de França, no mesmo século XIII, onde se constata a origem comum romana entre a supplicatio e a supplicacion, recurso de natureza excepcional dirigido à mais alta autoridade do reino, como era na tradição lusitana.

${ }^{82}$ Id. Ibid., p. 112.

${ }^{83}$ Id. Ibid., p. 109.

${ }^{84}$ COSTA, Mário Júlio de Almeida. op. cit., p. 231. Sobre a coadjuvação de Mestre Jacob das Leis ao Rei Sábio, confira-se, também, CAETANO, Marcello. op. cit., p. 340-342 e COSTA, Moacyr Lobo da. op. cit., p. 112.
} 
E porque Afonso X teria estudado na famosa Escola de Direito de Bolonha, ali teve contato com o direito justinianeu e o direito canônico, deles recuperando e reaproveitando os princípios mais relevantes.

\section{A importância das Sete Partidas é inquestionável porque ela representou "o veículo de introdução do direito comum na vizinha nação lusitana". 85}

Confirma tal asserção Moacyr Lobo da Costa, ao esclarecer que, tanto o Fuero Real, como a Lei das Sete Partidas foram traduzidos para o português no reinado de D. Dinis, no século XIII, e eram aplicadas como leis do reino e influíram na redação das Ordenações Afonsinas. ${ }^{86}$

E, neste passo, cabem algumas linhas sobre o tratamento dos recursos em Portugal, especialmente a antes referida Sopricação, para daí investigar como surgiu o recurso de revista.

Com efeito, a partir do início do século XIII, os reis Afonso II e III e, em seguida, D. Dinis, já no século seguinte, todos eles procuraram fortalecer a ainda incipiente monarquia portuguesa e, valendo-se da experiência castelhana, acima mencionada, que se inspirava no ressurgir do direito romano e nas práticas do direito canônico (acrescidos os direitos locais, daí configurando o "direito comum") ${ }^{87}$, promulgaram leis gerais, do que dá boa mostra a coleção exposta no Livro das Leis e Posturas e nas Ordenações de D. Duarte.

\footnotetext{
${ }^{85}$ CRUZ E TUCCI, José Rogério; AZEVEDO, Luiz Carlos de. Lições de história do processo civil lusitano, cit., p. 32.

${ }^{86}$ COSTA, Moacyr Lobo da. op. cit., p. 124-126, com destaque para a nota de rodapé $n^{\circ} 142$. Nessas páginas, vem realçada, também, a relevância que as Partidas atribuíam ao julgamento proferido contra a lei ou contra o foral, de modo que não poderia valer, ou seja, a nulidade equivalia à inexistência. O objetivo era político, tal como no direito romano, no qual se abeberou Mestre Jacob, tudo isso para "impor a supremacia das normas jurídicas estabelecidas pelo monarca e assegurar sua observância pelos órgãos judicantes em todo o reino". A violação de lei é tão importante para o sistema que ela veio a ser erigida, tanto em hipótese de cabimento do recurso de revista, como de ação rescisória, a qual, segundo o referido Autor, tem seu ancestral mais remoto exatamente na Lei das Sete Partidas.

${ }^{87}$ AZEVEDO, Luiz Carlos de. op. cit., p. 125-126 e p. 140, nas quais bem dilucida o fenômeno ocorrido a partir do século XI, quando confluíram o Direito Romano (redescoberto), o Direito Canônico e o Costumeiro, originando o ius comune, de índole universal, aplicável naquele ambiente europeu medieval. Sobre o utrumque jus, confiram-se as lições de José Rogério Cruz e Tucci na específica e já citada obra Jurisdição e poder, cit., p. 105-111 e, à p. 115, está posta esta síntese da época: "ius canonicum et civile sunt adeo conexa ut unum sine altere non intelegi postest". Tenha-se presente, também, o fenômeno da recepção do direito comum: transferência "da construção doutrinal e do método jurídico-científico desenvolvidos desde meados do século XII em Bolonha e, pouco depois, em diferentes universidades italianas e francesas," tal como afirma este último escritor citado (p. 138).
} 
Esta diretriz que se consagrou de forma definitiva, posteriormente, com as Ordenações Afonsinas, Manuelinas e Filipinas.

Essas leis gerais se tornaram a fonte primordial do direito, rejeitados os multifacetários forais, os costumes e os privilégios dos senhores locais. ${ }^{88}$ Mais do que isso, esses reis centralizaram em suas mãos a jurisdição, fenômeno que teve evolução mais lenta fora da península ibérica, em face da disputa de poder com a Igreja, como relata José Rogério Cruz e Tucci. ${ }^{89}$

Destaca Luiz Carlos de Azevedo que Afonso III foi quem tentou fazer a primeira codificação do reino e, já sob a influência do Direito Comum, editou a primeira lei permitindo a apelação ${ }^{90}$, contra as sentenças definitivas e interlocutórias (estas incluídas pela forte influência do direito canônico) "seguindo o recurso à semelhança do Direito Romano justinianeu (1254? 1265?)" 91

Na figura do Monarca, portanto, concentrava-se, a um só tempo, a fonte da legislação e da aplicação do direito.

Com esses propósitos, haveria de ser melhorado o aparato real de aplicação da justiça, daí por que são instituídos os representantes diretos do rei nos concelhos (juízes de fora-parte), para o exercício da jurisdição, quase que tomando o lugar dos "juízes da terra"

Passa a funcionar o tribunal real (Cúria Régia - Casa de Justiça, que acompanhava o Rei, observado perímetro de cinco léguas, e Casa do Cível, primitivamente em Santarém, depois em Lisboa, para além daquele marco), com os respectivos juízes de segundo grau (inicialmente os sobrejuízes, depois os ouvidores e os desembargadores); finalmente, vem a ser aprimorada a própria ordem do juízo, ou seja, o procedimento. ${ }^{92}$

\footnotetext{
${ }^{88}$ AZEVEDO, Luiz Carlos de. op. cit., p. 141.

${ }^{89}$ CRUZ E TUCCI, José Rogério. Jurisdição e poder, cit., p. 112-116.

${ }^{90}$ CRUZ E TUCCI, José Rogério; AZEVEDO, Luiz Carlos de. Lições de história do processo civil lusitano, cit., p. 62, que atribuem a D. Afonso II a primeira lei autorizando revisão das sentenças pelo Rei. Vide, também, CRUZ E TUCCI, José Rogério. Jurisdição e poder, cit., p. 160 ("apele logo, ca tal quero que seja custume de meu Reyno")

${ }^{91}$ AZEVEDO, Luiz Carlos de. op. cit., p. 142.

${ }^{92}$ CRUZ E TUCCI, José Rogério; AZEVEDO, Luiz Carlos de. Lições de história do processo civil lusitano, cit., p. 43-58 e 63 e AZEVEDO, Luiz Carlos de, op. cit., p. 184.
} 
Sucedendo a D. Afonso III, D. Dinis, fundou o Studium Generale ${ }^{93}$ de Lisboa (a D 1290), embrião dos estudos universitários portugueses, particularmente do ius comune. E, como antes referido, foi D. Dinis quem mandou traduzir as Flores de Las Leys e as Sete Partidas e, mais ainda, esforçou-se para consolidar a justiça pública, sendo de seu reinado farta legislação processual, particularmente contra abusos e procrastinações, como, também, sobre a apelação e sopricação (suplicação), de acordo com Lei de 07.07.1302. ${ }^{94}$

A suplicação, dirigida ao Rei ou à sua Casa de Justiça, era "agravo" (i.e. recurso) contra decisões definitivas proferidas pelos sobrejuízes em apelação, as quais, em princípio seriam irrecorríveis, mas abriam-se exceções, como nos feitos de competência originária do Tribunal, em razão das pessoas envolvidas ou das matérias discutidas .A admissibilidade só estava vinculada à vontade do Rei, ou seja, tratava-se de uma maneira de reforçar e insistir no princípio segundo o qual na figura do Monarca concentrava-se a "justiça maior". 95

As Ordenações Afonsinas trataram da "suplicação" (Ord. Af. 3. 109), reportando-se a uma lei de D. Pedro I; só caberia contra decisão definitiva ou com eficácia equivalente, desde que proferidas em Tribunal.

Ali encontram-se delineadas algumas particularidades e pressupostos desse recurso, que poderiam ser chamados extrínsecos, vale dizer, não ligados à matéria de direito a ser decidida, cabendo destacar os seguintes:

\footnotetext{
${ }^{93}$ Refoge dos propósitos destas linhas a candente discussão sobre a criação da primeira Universidade de Portugal, se em 12 de novembro de 1288, em $1^{\circ}$ de março de 1290 ou, ainda, 9 de agosto do mesmo ano. Também controversa a questão da fixação de sua sede, se em Lisboa ou em Coimbra. Certo é que Mário Júlio de Almeida Costa (op. cit., p. 228-230) explica que a primeira data diz respeito à carta enviada ao Papa Nicolau IV, dando-lhe conta de entendimento feito entre D. Dinis e vários dignitários eclesiásticos a respeito da fundação do Estudo Geral em Lisboa, por isso que solicitavam aprovação pontifícia, a qual, no entanto, só veio a ocorrer com a bula confirmatória de 9 de agosto de 1290. Quanto ao local, o próprio D. Dinis transferiu a Universidade para Coimbra em 1308, tendo regressado para Lisboa, em duas outras ocasiões, sob outros reis, voltando de novo para Coimbra e ali definitivamente fixada por D. João II, em 1537. Vide, também, a propósito, a detalhada exposição feita por Marcello Caetano (op. cit., p. 283-288), que alvitra ter sido melhor a localização em Coimbra por ser cidade menor e por minimizar os conflitos entre os dirigentes e estudantes, dotados de privilégios, em comparação com as autoridades urbanas da capital. Os estudos jurídicos do direito romano-canônico passaram a ter grande influência, conforme observou José Rogério Cruz e Tucci na obra Jurisdição e poder, cit., às páginas 147-149.

${ }^{94}$ AZEVEDO, Luiz Carlos de. op. cit., p. 142 e 186 e COSTA, Moacyr Lobo da. op. cit., p. 147-150. Observa José Rogério Cruz e Tucci, na obra Jurisdição e poder, cit., que a "supplicatio ressurge como sustentáculo dos podres estatal e eclesiástico e, sobretudo, como garantia do cidadão..." (p. 127).

${ }^{95}$ CRUZ E TUCCI, José Rogério; AZEVEDO, Luiz Carlos de. Lições de história do processo civil lusitano, cit., p. 237-238, que destacam a ligação desse recurso com a supplicatio do direito romano. Vide, também, CRUZ E TUCCI, José Rogério. Jurisdição e poder, cit., p. 161.
} 
a) alçada recursal ( $\S 3^{\circ}$ primeira parte): só seria possível a suplicação nos feitos de valor superior a "mil e quinhentos réis brancos"; desse valor para baixo não haveria "agravo (i. e. recurso) ${ }^{96}$;

b) prazo recursal $\left(\S 3^{\circ}\right.$, segunda parte): "agravem logo ou até dez dias contados do dia da publicação" da decisão, se presentes as partes ou procuradores, ou a partir da intimação de qualquer um deles);

c) distribuição da competência funcional para julgar a suplicação, em função do valor $\left(\S^{\circ}\right)$ : até cem mil libras de real, o julgamento seria feito pela Casa do Cível; acima desse montante, pela Casa de Justiça, o Tribunal junto ao Rei; ${ }^{97}$

d) pagamento prévio de custas $\left(\S 5^{\circ}\right)$ : "quinhentos réis brancos da moeda, que ora corre, que são trinta e cinco libras por real”); ${ }^{98}$

e) depósito recursal $\left(\S 6^{\circ}\right)$ : "quinhentos réis", salvo se o recorrente demonstrasse impossibilidade de assim proceder, daí submetendo-se essa questão à análise do Rei, "pois em tal caso deve socorrer a Nós, e Nós lhe proveremos como Direito".99

Se o recurso fosse provido, no todo ou na maior parte, esse depósito haveria de ser restituído à parte recorrente, "que assim pagou à nossa Chancelaria, por ser recebido o dito agravo, como dito é". 100

Anotam José Rogério Cruz e Tucci e Luiz Carlos de Azevedo que

não se deve olvidar que o monarca, mesmo delegando jurisdição, continuava a ser o supremo magistrado. E, assim sendo, nas Ordenações de D. Afonso V, ao lado da revista de justiça, cabível no caso de a sentença ser dada com base em provas inverídicas ou por peita do juiz, cria-se uma nova modalidade de revisão dos processos, denominada

\footnotetext{
${ }^{96}$ ORDENAÇÕES Afonsinas, cit., Livro 3, p. 395.

${ }^{97}$ Id. Ibid., p. 395-396.

${ }^{98}$ Id. Ibid., p. 396.

${ }^{99}$ Id. Ibid., p. 397.

${ }^{100}$ Id. Ibid., p. 397-398. Pondera José Rogério Cruz e Tucci (Jurisdição e poder, cit., p. 166) que o direito português, "ao assimilar a supplicatio romana, fê-lo de forma truncada. É que, no direito romano imperial, como vimos, o seu efeito principal era a retractatio do praefectus praetorio, o que não ocorria com o recurso da sopricação, porque, como observa Lobo da Costa, o princípio de que todo juiz podia revogar sua decisão interlocutória, antes de proferir sentença definitiva, floresceu da proibição de apelar-se contra a interlocutória simples;"
} 
revista de graça especial (3.108.6), que podia se admitida pelo monarca ainda que a sentença não contivesse vício algum. ${ }^{101}$

Nas Ordenações Manuelinas a suplicação vem tratada também no Livro III, capítulo 77, passando, no entanto, a ser chamada "Agravo Ordinário", não sofrendo, todavia, grandes modificações, a não ser

a) no que se refere aos valores monetários de fixação na alçada recursal (agora que haveria de ser superior a "quatro marcos de prata"102);

b) na distribuição da competência funcional entre tribunais, em razão da "quantia ou valia da condenação caiba na alçada do Julgador" (M. 3.77.8), que passa a ter maior destaque, a ponto de ser criada a figura de avaliador oficial (M 3.77.10); assim, de quatro marcos de prata até oito, o recurso seria julgada pela Casa do Cível e, a partir de oito, pela Casa da Sopricação, denominação então corrente da Casa de Justiça, o tribunal junto ao $\operatorname{Rei}^{103}$;

c) no depósito recursal, que passa a ser novecentos réis, podendo o pobre requerer isenção, desde que jurasse não ter bens nem condições de pagar o recurso, mas que proferisse um "pai nosso pela alma d'El Rey D. Dinis" e, ainda, desde que o requerimento fosse feito "no tempo que havia de pagar o agravo". ${ }^{104}$

Nas Ordenações Filipinas, por se tratar de matéria processual e dando continuidade à mesma estrutura das ordenações anteriores, o agravo ordinário também vem tratado no Livro III, agora, porém, no Capítulo 84. Fundamentalmente, restam inalteradas as condições de admissibilidade previstas nas Manuelinas, por exemplo, o prazo de dez dias

\footnotetext{
${ }^{101}$ CRUZ E TUCCI, José Rogério; AZEVEDO, Luiz Carlos de. Lições de história do processo civil lusitano, cit., p. 239-240. A "Revista de Justiça", filha da restitutio in integrum, resultará na "ação rescisória", autônoma portanto, ao passo que as outras "revistas", subsistirão como recurso propriamente dito, vale dizer, dentro do mesmo processo.

${ }^{102}$ ORDENAÇÕES Manuelinas. Lisboa: Ed. Fundação Calouste Gulbenkian, 1984, Livro 1, p. 284.

${ }^{103}$ Id. Ibid., p. 285.

${ }^{104}$ Id. Ibid., p. 290.
} 
(F.3.84.1) ${ }^{105}$, o pagamento de custas (F. 3.84.1) ${ }^{106}$ e do depósito recursal, com eventual isenção por motivo relevante ou miserabilidade (3.84.9 e 10) ${ }^{107}$.

O transcorrer dos tempos e as modificações dos padrões monetários influíram na fixação da alçada recursal, conforme tratar-se de bens móveis (100.000 réis, depois 150.000) ou imóveis (80.000 réis, depois 100.000). ${ }^{108} \mathrm{Em}$ razão dos montantes envolvidos, o recurso seguia para a Relação do Porto ou para a Casa da Suplicação. ${ }^{109}$

A partir de 1609, com Felipe II de Portugal, no Brasil se dava de forma semelhante: se em jogo bens móveis até 3.000 cruzados o recurso era apreciado pela Casa da Relação do Brasil; superado esse padrão, seguia para a Casa da Suplicação em Lisboa.

À época de D. José (1750-1777), é criada a Casa da Relação do Rio de Janeiro, com competência para o julgamento dos agravos ordinários interpostos contra as sentenças definitivas dos Ouvidores gerais dentro do distrito dessa Relação, a qual, com a vinda do Príncipe Regente D. João, em 1808, passa a ser chamada de Casa da Suplicação do Brasil. $^{110}$

Finalmente, com a reforma judiciária de 1832, no direito lusitano foi abolido o agravo ordinário, só cabendo contra as decisões definitivas as apelações e o recurso de revista, agora encaminhado ao Supremo Tribunal de Justiça, que passou a figurar no ápice da estrutura judiciária.

Sintetizaram José Rogério Cruz e Tucci e Luiz Carlos de Azevedo, ${ }^{111}$ invocando Jorge de Cabedo,

que no direito processual lusitano o vocábulo supplicatio deu origem a dois institutos: um era a sopricação ou, mais precisamente, agravo

\footnotetext{
${ }^{105}$ ORDENAÇÕES Filipinas. Lisboa: Ed. Fundação Calouste Gulbenkian, 1985. Livro, p. 694.

${ }^{106}$ Id. Ibid.

${ }^{107}$ Id. Ibid., p. 695.

${ }^{108}$ CRUZ E TUCCI, José Rogério; AZEVEDO, Luiz Carlos de. Lições de história do processo civil lusitano, cit., p. 242.

${ }^{109}$ Tenha-se presente que a Casa da Suplicação era "o maior Tribunal de Justiça de nossos Reinos, e em que as causas de maior importancia se vem a apurar e decidir", assim o dizendo logo a primeira frase do Título I do Livro Primeiro das Ordenações Filipinas (op. cit. p. 1), ao tratar da relevante função do regedor da Casa da Suplicação. De outro lado, o nome, Casa da Suplicação, atribuído para o mais importante tribunal do Reino, em boa medida pode ser fruto de metonímia, por ali se julgarem as suplicações, recurso extremo e de peculiar significação.

${ }^{110}$ CRUZ E TUCCI, José Rogério; AZEVEDO, Luiz Carlos de. Lições de história do processo civil lusitano, cit., p. 243. Vide, também, CRUZ E TUCCI, José Rogério. Jurisdição e poder, cit., p. 191-196 (Considerações finais à guisa de conclusão) onde se vê a trajetória da supplicatio até o Império.

${ }^{111}$ Id. Ibid.
} 
ordinário ("supplicatio ordinaria dicitur"), cabível quando "non licet appelare ob dignitatem \& praeminentiam eorum qui sententiam tulerunt, suplicare potest ad Regem"; o outro, extraordinário, "est supplicatio quae revisio dicitur", ou seja, a revista, e que "habent peculiarem naturam"(Decisionum, pt. II, Antuerpia, J. Verdussen, 1684, p.173). A revista, destarte, era considerada um remédio excepcional, porque somente era cabível quando fossem inadmitidos a apelação e o agravo ordinário, e sempre contra os acórdãos das Relações em questões que excedessem a alçada. ${ }^{12}$

Chega-se, portanto, às duas formas de revista, enunciadas nas três ordenações do reino, fonte ou tronco comum que veio a desmembrar-se na legislação brasileira posterior.

Convém rememorar um detalhe fundamental: a revista, tal como posta na tradição lusitana, indicava, simultaneamente, duas hipóteses de revogação da sentença, ou seja, a primeira que veio a se tornar a revista de justiça (ancestral da ação rescisória) e a segunda que, verdadeiramente, era um recurso, vale dizer, dentro do mesmo processo.

Deixando-se de lado a observação feita por Moacyr Lobo da Costa a respeito de interpolações feitas na primeira lei de D. Afonso II, que tratou da revista, ${ }^{113}$ comparadas as versões que se encontram no Livro das Leis e Posturas, nas Ordenações de D. Duarte e nas Ordenações Afonsinas, certo é que tiveram o propósito de insistir em que a revisão era, fundamentalmente, fruto de "mercê" do Rei, detentor último do Poder e da administração da Justiça, à exemplo do que aconteceu no Principado Romano.

Vejam-se, portanto, nas Ordenações Afonsinas as hipóteses de cabimento da revista que estão colocadas (A. 3.108), sob o título "Dos que pedem que lhes revejam os feitos e sentenças desembargadas pelos Juízes da Suplicação". Assim, observado o princípio de não discriminação entre pessoas, vencedores e vencidos, em princípio, as decisões não haveriam de ser revistas, salvo

se os condenados alegarem e afirmarem que foram dadas por falsas provas, a saber, testemunhas falsas, ou escrituras, declarando e especificando logo a espécie da falsidade, segundo mais detalhadamente contém sobre isso estas Ordenações no Título, Da fé que se deve dar aos instrumentos públicos e no Título, Das provas que se devem fazer por escrituras públicas, falsidade que, todavia, não havia sido antes alegada até esse tempo nos feitos, ou, se foi alegada, não foi recebida; ou dizerem que as sentenças foram dadas por Juízes subornados e peitados; ou Nós (o

\footnotetext{
${ }^{112}$ No mesmo sentido são a análise e a conclusão de Moacyr Lobo da Costa, op. cit., p. 178-181.

${ }^{113}$ COSTA, Moacyr Lobo da. op. cit., p. 143-146.
} 
Rei) por graça especial mandarmos rever ditas sentenças e processos de onde saíram, revista esta que será feita nos ditos casos por nossa especial ordem e não de outro modo. ${ }^{114}$

Como se vê, na primeira parte, o $\S 6^{\circ}$ trata da revisão de julgamentos por motivo de falsas provas e de suborno dos juízes (hipóteses da revista de justiça, futura ação rescisória); a segunda alude à revisão por "graça especial" do Rei, esta, portanto, incondicionada, exigindo, todavia, o $§ 7^{\circ}$ depósito de "trinta escudos de ouro", que seriam restituídos se o "agravo" fosse reconhecido ou que reverteriam à parte adversa em caso improcedência 115

Neste momento, refaz-se ponto de contato com o que acima foi dito a respeito da sentença inexistente (nenhuma) ${ }^{116}$ e que, por isso, não precisaria ser contrastada por apelação, "pois em todo tempo pode ser revogada" (A. 3.78. pr.), cuja caracterização ocorre nos seguintes casos:

a) falta de citação;

b) proferida contra outra sentença anterior;

c) por suborno do juiz;

d) prova falsa e proposital (acinte) contra ausente;

e) proferida só por um ou alguns juízes, quando outros estavam também designados para o caso;

f) proferida por juiz incompetente, no todo ou em parte;

g) proferida contra direito expresso. ${ }^{117}$

Como se vê, alguns dos motivos causadores da nulidade coincidem com as hipóteses de cabimento da revista de justiça (v.g. prova falsa e suborno), o que pode

\footnotetext{
${ }^{114}$ ORDENAÇÕES Afonsinas, cit., Livro 3, p. 392-393.

${ }^{115}$ COSTA, Moacyr Lobo da. op. cit., p. 157, que, reportando-se às Ordenações Afonsinas, identifica que o depósito prévio só era exigido para a revista de graça especial, abolida essa exigência para a revista de justiça, diferentemente do que acontecia ao tempo de D. Dinis.

${ }^{116}$ Vide, supra p. 11-13.

${ }^{117}$ ORDENAÇÕES Afonsinas, cit., Livro 3, p. 300-301.
} 
constituir paradoxo, mas só aparente, pois a intenção do legislador era muito firme e decidida para coibir os abusos causadores desse tipo nulidade, daí o "concurso de meios processuais," peculiaridade destacada por Luiz Carlos de Azevedo, José Rogério Cruz e Tucci e Moacyr Lobo da Costa. ${ }^{118}$

A violação de direito expresso assumiu destaque e importância semelhantes às hipóteses de nulidade, assim como aquelas previstas para a revista de justiça.

Nas Ordenações Manuelinas, as revistas continuam sendo tratadas de forma conjunta no Livro III, capítulo LXXVIII, vale dizer, a revisão dos feitos poderia ser requerida naquelas hipóteses de peita, suborno, provas falsas ou falsas escrituras e, ainda, a revista de graça especial, "a qual revista mandamos que se não faça em nenhum dos ditos caso sem Nosso especial mandado"119

As Manuelinas introduziram singular modificação na admissibilidade da revista de graça especial (antes, só condicionada à vontade do rei): ela passou a depender de prévia análise de dois "letrados"; se ambos estivessem de acordo, a concessão da revisão seria permitida, seja porque a "sentença não foi direitamente dada", seja porque pairou alguma suspeição sobre os desembargadores que atuaram no feito ou, também, porque o feito é de tal natureza e a sentença não foi bem dada, que notoriamente não deve "passar sem ser melhor examinada.",120

Permanece a obrigatoriedade do depósito prévio de 60 “cruzados d'ouro" (M. 3.78.2), os quais seriam devolvidos à parte que saísse vitoriosa, ainda que proporcionalmente.

\footnotetext{
${ }^{118}$ CRUZ E TUCCI, José Rogério; AZEVEDO, Luiz Carlos de. Lições de história do processo civil lusitano, cit., p. 274. Sobre essa dupla proteção, no mesmo sentido é a lição de Moacyr Lobo da Costa, op. cit., p. 167.

${ }^{119}$ ORDENAÇÕES Manuelinas, cit., Livro 1, p. 293. Sobre a participação de um ou dois letrados, Moacyr Lobo da Costa (op. cit., p. 165) anotou discrepância entre a edição de 1514 e a de 1521 das Ordenaç̃̃es Manuelinas.

${ }^{120}$ Id. Ibid., Livro 1, p. 294. Esta passagem evidencia o início da prática de se proceder ao exame prévio de admissibilidade da revista em dois distintos momentos, semelhantemente ao que, nos dias atuais, se faz no juízo a quo e, depois, no ad quem.
} 
Se a revisão for improcedente, esse valor reverterá aos julgadores, pois a interposição da revista era considerada "uma espécie de injúria para os juízes"121e poderia acarretar sanções de cunho disciplinar.

O Rei poderia conceder isenção do depósito, em se tratando de pessoa miserável ou pobre (M.3.78.2).

Ficou estabelecido o prazo de dois meses para o oferecimento da revista, contandose "do dia que as sentenças foram publicadas". ${ }^{122}$

Os desembargadores que participaram do primeiro julgamento não participam daquele de revisão; poderão ser chamados, todavia, para prestar informações ou para declarar os fundamentos de seu voto anterior; se tivesse havido divergência, haveriam de comparecer os formadores de uma e de outra corrente, "tanto dos que foram pro, como dos que foram contra." 123

Em princípio, o julgamento de revisão deveria ter a participação de mais juízes do que o número dos atuaram na decisão revisanda, salvo dependendo da confiança que o Rei depositasse nesses julgadores, que poderão ser em número menor (M.3.78.6); o critério de quantidade, sucumbia ao da qualidade.

Finalmente, no último parágrafo desse capitulo, encontram-se outras peculiaridades do recurso de graça especial (M.3.78.7), que o diferenciam da revista de justiça, esta, como se disse, a forma embrionária da ação rescisória brasileira.

\section{Com efeito, na revista de graça especial "as partes não podem alegar nem dizer coisa alguma de fora dos Autos; salvo se forem alegações de direito",124; o julgamento é feito nos próprios autos, confirmando ou revogando a decisão}

\footnotetext{
${ }^{121}$ CRUZ E TUCCI, José Rogério; AZEVEDO, Luiz Carlos de. Lições de história do processo civil lusitano, cit., p. 275.

${ }^{122}$ ORDENAÇÕES Manuelinas, cit., Livro 1, p. 295.

${ }^{123}$ Id. Ibid., p. 296.

${ }^{124}$ Id. Ibid., p. 297 . Aqui se constata a gênese de fundamental característica do recurso de revista do processo do trabalho, que não permite rediscussão fática e probatória, em contraposição aos apelos de índole ordinária, sendo nesse sentido a Súmula 126/TST, in verbis: RECURSO. CABIMENTO (mantida) - Res. 121/2003, DJ 19, 20 e 21.11.2003. Incabível o recurso de revista ou de embargos (arts. 896 e 894, "b", da CLT) para reexame de fatos e provas.
} 
revisanda; "parece, fora de dúvida, tratar-se de um recurso extraordinário contra a sentença", anotou Moacyr Lobo da Costa. ${ }^{125}$

E, porque, no caso da revista de justiça, a parte final do referido parágrafo $7^{\circ}$ permitia dilação probatória para a demonstração da falsa prova ou do suborno do juiz, circunstância raramente evidente (as próprias causas da revisão), ela haveria de ser processada em outros autos, ou seja, não ostentava natureza recursal extraordinária e, sim, figura "sui generis", "misto de recurso e de ação" e "uma figura na qual, sem grande esforço de imaginação, é possível antever o ancestral lusitano da moderna ação rescisória do direito brasileiro"

Nas Ordenações Filipinas, comparando-as com as Manuelinas, encontraremos pequenas modificações no tratamento dispensado às revistas de justiça e de graça especial, ambas incluídas no capítulo XCV do Livro III.

A primeira continua admissível no caso de falsas provas ou falsas escrituras e no de suborno ou peita dos juízes. Já a segunda, permanecia condicionada à prévia análise de dois desembargadores, para tanto designados pelo Rei, que haveriam de concordar “que a sentença não foi justamente dada.",

Sempre a critério d' El Rey, a revista de graça especial também poderia ser concedida se ele vislumbrasse

\begin{abstract}
alguma suspeição em algum Desembargador dos que no feito foram, tal que, posto que se não possa pôr em forma, para per Direito proceder, nos pareça porém que basta para Nós mandarmos rever, ou por o feito parecer em si tal, e de tal qualidade, e a sentença não bem dada, que notoriamente concebamos, que não deva passar sem ser melhor examinada. ${ }^{128}$
\end{abstract}

Foi mantido o depósito prévio de 60 cruzados (F.3.95.2), que reverterá ao vencedor, no todo ou em parte, conforme divisão a ser feita pelo Regedor e pelos Julgadores, atribuindo-se a parcela devida aos Desembargadores que haviam participado da decisão

\footnotetext{
${ }^{125}$ COSTA, Moacyr Lobo da. op. cit., p. 167.

${ }^{126}$ Id. Ibid., p. 166.

${ }^{127}$ ORDENAÇÕES Filipinas, cit., Livro 3, p. 744. Trata-se do juízo de admissibilidade prévia, posteriormente mantido na tradição legislativa.

${ }^{128}$ Id. Ibid.
} 
revisanda ou a seus herdeiros. Permanece a possibilidade de o Rei conceder isenção do depósito ao pobre (F.3.95.2, in fine).

Dá-se o mesmo tratamento ao prazo de interposição da revista de graça especial (dois meses), contados da publicação da sentença ou do julgamento de eventuais embargos de declaração.

Todavia, "alegando as partes algumas razões, por que pareça, que devem ser admitidas as tais petições, dar-se-nos-á disso conta para mandarmos o que nos parecer"129. Noutras palavras, o Monarca poderia relevar o prazo, de forma discricionária. Daí por que, a propósito, arremata Moacyr Lobo da Costa que

o poder que se reservou El-Rei, de conceder a revista requerida fora do prazo, em vista das razões alegadas pelas partes, vai gerar a figura da Revista de Graça Especialíssima, criada no reinado de D. José I, pela Lei de 3 de novembro de 1768 , no âmbito da chamada Reforma Pombalina. ${ }^{130}$

A participação dos desembargadores no julgamento continua da mesma forma das Manuelinas (F.3.95.4, 5 e 6); permanece vedada a invocação de matéria fora dos autos, "salvo se forem alegações de direito"131.

As novidades filipinas restringem-se à observância de alçada superior a 100.000 réis para bens de raiz e 150.000 para bens móveis, (F.3.95.8), à impossibilidade de recorrer de revista "havendo três sentenças conformes, em qualquer quantia que seja" (F.3.95.8, in fine $)^{132}$; quando a revista já tivesse sido negada (pelos dois desembargadores), tivesse sido julgada ou inadmitida pelo Rei (F.3.95.9); à vedação de uso contra decisões interlocutórias $^{133}$ ou contra julgamento de suspeições (F.3.95.12).

\footnotetext{
${ }^{129}$ ORDENAÇÕES Filipinas, cit., Livro 3, p. 744.

${ }^{130}$ COSTA, Moacyr Lobo da. op. cit., p. 176. Esta prática existe no Direito Argentino, com se verá.

${ }^{131}$ ORDENAÇÕES Filipinas, cit., Livro 3, p. 745.

${ }^{132}$ Aqui, parece existir a influência do Direito Canônico, quando exigia as três decisões conformes.

${ }^{133}$ Especificamente, no processo do trabalho, há muito está consagrada a vedação de recurso em geral e, particularmente, o de revista contra decisões interlocutórias, tal como se vê na Súmula 214/TST, in verbis: DECISÃO INTERLOCUTÓRIA. IRRECORRIBILIDADE (nova redação) -Res.127/2005, DJ 14, 15 e 16.03.2005. "Na Justiça do Trabalho, nos termos do art. 893, § $1^{\circ}$, da CLT, as decisões interlocutórias não ensejam recurso imediato, salvo nas hipóteses de decisão: a) de Tribunal Regional do Trabalho contrária à Súmula ou Orientação Jurisprudencial do Tribunal Superior do Trabalho; b) suscetível de impugnação mediante recurso para o mesmo Tribunal; c) que acolhe exceção de incompetência territorial, com a remessa dos autos para Tribunal Regional distinto daquele a que se vincula o juízo excepcionado, consoante o disposto no art. $799, \S 2^{\circ}$, da CLT".
} 
Finalmente, faz-se a exigência de que a petição da revista seja subscrita por procuradores que atuem nas Relações (F.3.95.13), no que vêem José Rogério Cruz e Tucci e Luiz Carlos de Azevedo, citando Moacyr Lobo da Costa, que essa providência visava não banalizar as pretensões de revisão, seja pela "quase ofensa" que, à época, admitia-se ser perpetrada contra a figura dos juízes, ao ser interposto esse tipo de apelo, seja pela quase "habilitação/credenciamento" profissional que o manejo desse recurso extraordinário passou a exigir. ${ }^{134}$

Cumpre referir, por derradeiro, à Revista de Graça Especialíssima, pois esta será a mais significativa alteração em matéria recursal, que também teve aplicação no Brasil, até um pouco depois da independência, em 1822, momento a partir do qual, paulatinamente, deixar-se-ão de lado as peculiaridades da legislação portuguesa, focando-se na brasileira imperial e, depois, na republicana, que, afinal, implantou a revista no processo do trabalho.

A Revista de Graça especialíssima nasce no bojo da chamada Reforma Pombalina ou do Iluminismo Português, que teve seu ponto alto na posteriormente denominada Lei da Boa Razão, de 18 de agosto de $1769,{ }^{135}$ da qual se extraem pontos relevantes para o estudo do recurso de revista, particularmente no que se refere à violação de lei e à busca de uniformidade das decisões proferidas pelos Tribunais.

De fato, esse diploma, dentre outros aspectos, ${ }^{136}$ evidencia nítida tentativa de fazer prevalecer o direito pátrio português em todos os julgamentos, reduzindo a influência do direito romano e do canônico (cfr. “item” $9^{\circ}$ da própria Lei da boa razão).

Além disso, tal como vem exposto no seu prólogo, visava ela a se precaver contra "interpretações abusivas, que ofendem a majestade das Leis, desautorizam a reputação dos Magistrados", tornam perplexa a justiça dos litigantes, impedindo que “possa haver aquela provável certeza” na aplicação do direito, fabricando-se injustas demandas, muitas vezes, "animadas por frívolos pretextos tirados das extravagantes sutilezas, com que aqueles que as aconselham e promovem querem temerariamente entender as Leis mais claras e menos susceptíveis de inteligências, que

\footnotetext{
${ }^{134}$ CRUZ E TUCCI, José Rogério; AZEVEDO, Luiz Carlos de. Lições de história do processo civil lusitano, cit., p. 278.

${ }^{135}$ ORDENAÇÕES Filipinas, cit., Livro 3, p. 725-730 (Aditamentos).

${ }^{136}$ Confira-se, a propósito da Lei da Boa Razão, COSTA, Mário Júlio de Almeida. op. cit., p. 357-363, COSTA, Moacyr Lobo da. op. cit., p. 185-188 e CRUZ E TUCCI, José Rogério. Jurisdição e poder, cit., p. 178-182.
} 
ordinariamente são opostas ao espírito delas e que nelas se acha literalmente significado por palavras exclusivas de tão sediciosas e prejudiciais cavilações."137

Por sua vez, o item $8^{\circ}$ da Lei da Boa Razão cuidou de atribuir só à Casa da Suplicação a possibilidade de editar assentos, ou seja, interpretar a lei com sentido vinculativo para o futuro, tal como já haviam disciplinado as Ordenações Manuelinas e Filipinas $^{138}$.

Ali está expressamente consignado que a expedição de assentos "não foi estabelecida para as Relações do Porto, Bahia, Rio de Janeiro, e Índia, mas sim, e tão somente, para o Supremo Senado da Casa da Suplicação." 139

Pois bem, foi a Carta de Lei, ${ }^{140}$ de 3 de novembro de 1768 , que, de forma clara e contundente, trouxe restrições às revistas, em face do então corrente abuso na sua utilização, chegando ao ponto de abolir a Revista de Justiça e de só admitir a Revista de Graça Especial e criar, como se disse, a Revista de Graça Especialíssima, "suprema expressão do absolutismo real," no dizer de Moacyr Lobo da Costa, autor este que, aliás, transcreve o inteiro teor dessa carta de lei de D. José I. ${ }^{141}$

As revistas só seriam admitidas nos exclusivos casos de manifesta nulidade ou de injustiça notória, tal como antes já estavam disciplinadas nos Títulos LXXV e XCV das Ordenações Filipinas, acima citados. A injustiça notória, porém, veio a ser caracterizada nesse diploma como decorrente daquela sentença que foi proferida “contra direito expresso", o qual deve ser

o Direito Pátrio dos Meus Reinos, e não as Leis Imperiaes, ou Direito Civil, de que resulta a mesma perplexidade do domínio, e incerteza do direito das partes, que he da Minha Paternal Intenção evitar quando possível for: E isto, não obstante a outra Ordenação do Livro terceiro, Título sessenta e quatro. ${ }^{142}$

Já a Revista de Graça Especialíssima veio a ser admitida para as causas criminais (para as quais, antes, era proibida a revista de graça especial) e, ainda, para aquelas

\footnotetext{
${ }^{137}$ ORDENAÇÕES Filipinas, cit., Livro 3, p. 726 (Aditamentos).

${ }^{138}$ COSTA, Mário Júlio de Almeida. op. cit., p. 296-299.

${ }^{139}$ ORDENAÇÕES Filipinas, cit., Livro 3, p. 727 (Aditamentos).

${ }^{140}$ Sobre as formas de criação legislativa, vide COSTA, Mário Júlio de Almeida. op. cit., p. 291.

${ }^{141}$ COSTA, Moacyr Lobo da. op. cit., p. 188-191.

${ }^{142}$ Id. Ibid., p. 190.
} 
situações nas quais já havia "passado o termo estabelecido pela Lei para a revisão das causas Cíveis" (sic). ${ }^{143}$

Eis aqui, talvez, o principal motivo para se reconhecer que a Revista de Graça Especialíssima constitui-se num exemplo desastrado do iluminismo português, que frutos bons rendeu noutras searas, dentre elas a do ensino (lembre-se de Luiz Antônio Verney e de Paschoal José de Mello Freire) e da atividade científica, como escreveu Mário Júlio de Almeida Costa. ${ }^{144}$

Essa lei vedava, também, a produção de qualquer documento novo nas revistas de graça especial e especialíssima, o que, na prática, tornava impossível, por exemplo, demonstrar a corrupção dos julgadores ou a superveniência de novas provas, prática admitida na antiga Revista de Justiça, que, bem por isso, caracterizava-se como verdadeira ação nova ("rescisória") e, não, recurso, como vinham funcionando as revistas propriamente ditas.

Moacyr Lobo da Costa, cita comentário de Joaquim Caetano Pereira e Sousa, para realçar o caráter arbitrário da Revista de Graça Especialíssima:

Esta Revista não está sujeita a norma alguma particular, e pende em tudo do Real arbítrio. Regularmente o Príncipe, nestes recursos extraordinários e imediatos, manda informar algum Ministro com audiência da parte. Umas vezes decido o Príncipe o caso por si mesmo, e a decisão baixa por Decreto ou aviso expedido pela mesma Secretaria de Estado: outras vezes nomeia juízes que decidam, outras vezes finalmente manda consultar o Tribunal competente; e no caso de se conformar com a consulta, sendo esta a favor do recorrente, pelo mesmo Tribunal se expede Provisão em que se declara, que a Ordem é de especial resolução Régia. ${ }^{145}$

Em síntese, a Revista de Graça Especialíssima, parece contrariar o mote central do próprio iluminismo português, pois foge da "boa razão", das leis naturais e do racionalismo.

${ }^{143}$ COSTA, Moacyr Lobo da. op. cit. Veja-se, ainda, CRUZ E TUCCI, José Rogério. Jurisdição e poder, cit., p. 179.

${ }^{144}$ COSTA, Mário Júlio de Almeida. op. cit., p. 351-353 e CRUZ E TUCCI, José Rogério, Jurisdição e Poder, op. cit., p. 180.

${ }^{145}$ COSTA, Moacyr Lobo da. op. cit., p. 199 e CRUZ E TUCCI, José Rogério. Jurisdição e poder, cit., p. 183-184. 
A Revista de Graça Especialíssima só fez realçar a postura absolutista do monarca, pois, bastava sua vontade para que fosse relevado ou desconsiderado o prazo fixado nas próprias Ordenações, ou seja, por força duma penada real, ignoravam-se os dois meses já transcorridos para o oferecimento da revista.

Significou, também, retrocesso, pois, como se viu acima, ao tratar da revista de graça especial, ao tempo das Ordenações Manuelinas, o Rei ouvia "letrados" (primeiro um, depois, pelo menos dois) antes de decidir se mereceria acolhimento o recurso, ao passo que, agora, necessariamente assim não procederia.

Tudo ficava condicionado, à "graça", à mercê ou ao favor do Rei, em cuja pessoa e descortino estavam cumuladas as hipóteses de admissibilidade e de julgamento do próprio recurso. "Até a Reforma Judiciária de 1832, promovida por D. Pedro, Duque de Bragança, prevaleceu o sistema processual criado em 1768."146

Esta foi a sistemática recursal que chegou até o Império do Brasil, consolidado em 07 setembro de 1822, momento a partir do qual se desgarra do legado português, não totalmente, por certo, como se verá, oportunamente.

No entanto, importante aqui referir que, tanto a Revista de Graça Especial, como a Revista de Graça Especialíssima foram extintas pelo Decreto ${ }^{\circ} 24$, de 16 de maio de 1832 (norma instituidora da reforma ), cujo art. 243 previa a existência de recurso de revista contra a sentença proferida por tribunal de segunda instância, observados os mesmos requisitos e prazos próprios da apelação, não mais existindo diferenças de recorribilidade em razão do juiz que havia antes atuado.

Já o art. 244 atribuía ao Supremo Tribunal de Justiça (a antiga Casa da Suplicação) disciplinar em seu regimento os casos em que tomaria conhecimento do feito, para conceder ou negar a revista. "Todavia, antecipando-se ao regimento, o legislador baixou, três dias depois, o decreto de 19 de maio, destinado a fixar definitivamente as atribuições e ordem do serviço do Supremo Tribunal de Justiça criado pelo decreto 16 do mesmo mês, como se declara no respectivo preâmbulo" ${ }^{\text {147 }}$

\footnotetext{
${ }^{146}$ CRUZ E TUCCI, José Rogério; AZEVEDO, Luiz Carlos de. Liçães de história do processo civil lusitano, cit., p. 280.

${ }^{147}$ COSTA, Moacyr Lobo da. op. cit., p. 201. Pode-se dizer que esta situação guarda alguma semelhança com a delegação dada ao Tribunal Superior do Trabalho para disciplinar em seu Regimento a admissibilidade prévia dos recursos de revista, sob o critério da transcendência, tal como previsto no art. $2^{\circ}$ da MP 2226/0, o que, na prática, não ocorreu.
} 
Afinal, a revista não mais dependia da "munificência do príncipe"148, submetendo-se a um critério legalmente previsto, qual seja, quando houvesse nulidade nos autos, que não tenha sido antes discutida.

Definia o art. $3^{\circ}$ do referido Decreto que essa nulidade consistiria na violação direta às Leis do Reino, seja na preterição de uma formalidade que a legislação reputava essencial e sob essa cominação, seja no julgamento contrário a literal disposição da lei.

Estas, portanto, as marcas indeléveis da revista, doravante submetida a uma disciplina legal e confiada a um órgão jurisdicional (não mais ao Rei), tudo isso que, na sua evolução, não deixa de evidenciar as nítidas origens romanas e ibéricas, que foram repassadas para o Brasil, tal como descritas por José Rogério Cruz e Tucci. ${ }^{149}$

\subsection{O Recurso de Revista no Brasil}

Mozart Victor Russomano, em sua clássica obra "Comentários à Consolidação das Leis do Trabalho", há muito, sustentava que o recurso de revista trabalhista, "na história do direito nacional, aparece no Império, provindo do direito romano, através do direito português" ${ }^{\prime 150}$, sendo esta, exatamente, a trajetória histórica que se busca identificar e explicar.

Também Estêvão Mallet sustenta que no "Brasil o verdadeiro embrião do que viriam a ser os recursos de natureza extraordinária estava na revista, importada do direito português". ${ }^{151}$ Este mesmo Professor menciona, também, estudos feitos por renomados autores que viram “na suplicação francesa do século XIV, admitida por São Luís contra as

\footnotetext{
${ }^{148}$ COSTA, Moacyr Lobo da. op. cit., p. 202. Vide, ainda, CRUZ E TUCCI, José Rogério. Jurisdição $e$ poder, cit., p. 184, onde indica as hipóteses de cabimento da revista, fixadas no art. $2^{\circ}$ do Decreto de 19 de maio de 1832: "Eram fundamento da revista as nulidades constantes dos autos, quer provenientes de se ter preterido alguma formalidade essencial (errores in procedendo), quer de não ter havido na aplicação das leis do reino conformidade com a sua literal disposição" (cf. Merêa, Bosquejo histórico do recurso de revista cit.,p. 66-67)".

${ }^{149}$ CRUZ E TUCCI, José Rogério. Jurisdição e poder, cit., p. 191-196 (Considerações finais à guisa de conclusão)

${ }^{150}$ RUSSOMANO, Mozart Victor. Comentários à Consolidação das Leis do Trabalho. 5. ed. Rio de Janeiro: José Konfino Editor, 1960. v. 5, p. 1568.

${ }^{151}$ MALLET, Estêvão. Do recurso de revista no processo do trabalho, cit., p. 27. Note-se; "os recursos de natureza extraordinária”, não só a revista.
} 
sentenças das cortes do rei, o antecedente mais remoto dos recursos de natureza extraordinária." 152

De fato, Paul Viollet, examinando o livro II (dos) "Les Établissements de Saint Louis" (recueil d'ordonnances et règlements), ao tratar das vias recursais contra os julgamentos dos senhores feudais esclarece que o "amendement de jugement" evidenciava a influência do direito romano imperial, pois funcionava como a supplicatio, vale dizer, se os julgadores locais se recusavam a rever o julgamento, apelava-se diretamente ao Rei. “'L'Usage d'Orleanais nous parle également de supplication et d'amendement, lorsqu'il s'agit d'un jugement prononcé par un officier du roi. Ainsi c'est en se reportant à la théorie romaine de la supplicatio qu'on se rend compte des formes de procedure d'amendement." 153

Adolphe Tardif também alude à supplicacion como via recursal última, que se fazia para a mais alta autoridade, o rei: “La coutume d'Anjou nous dit même qu'on ne peut demander d'amendement qu'en la cour le roi. On ne saurait, en effet, fausser ces sentences parce qu'on ne trouverait point une juridiction qui pût faire droit, le roi ne tenant que Dieu et de lui-même". 154

Estes Autores franceses do século XIX, portanto, viram uma conexão entre a supplicatio do direito romano imperial e a supplicacion da época de Luís IX, exatamente porque se tratava de uma derradeira forma de busca de justiça, agora dirigida ao rei, como destaca Adolphe Tardif, transcrevendo trecho do livro II, 16, do "Les Établissements de Saint Louis" (língua francesa do século XIV) : "car supplicacions doit estre faite en cort de roi, non mie appel, car apiaus contient felonie et iniquité" ${ }^{155}$, estas duas circunstâncias que revelam o motivo excepcional.

Continuando, portanto, nessa linha de idéias que procura demonstrar os pontos de contato entre direito romano e o lusitano no trato dos recursos extraordinários, até esta parte, relembra-se singularidade histórica que, por mais um motivo, une Portugal e Brasil:

\footnotetext{
${ }^{152}$ MALLET, Estêvão. Do recurso de revista no processo do trabalho, cit.

${ }^{153}$ VIOLLET, Paul. Les établissements de Saint Louis. Paris: Librairie Renouard, 1881, t. 1, p. 218-219. Disponível <http://gallica.bnf.fr/ark:/12148/bpt6k5493358m.r=Les+\%C3\%A9tablissements+Saint+Louis.langPT>. Acesso em: 25 out. 2001.

${ }^{154}$ TARDIF, Adolphe. La procédure civile et Ccriminelle aux XIII ${ }^{\text {ème }}$ et XIVème siècles ou procédure de transition. Paris: Alphonse Picard, 1885. p. 127. Disponível em: http://gallica.bnf.fr/ark:/12148/bpt6k716934.r=Adolphe+Tardif.langPT. Acesso em: 25 out. 2010.

${ }^{155}$ Id. Ibid., p. 127.
} 
foi o Imperador do Brasil, D. Pedro I (Pedro IV da Lusitana Terra) que, uma vez proclamada a Independência e estruturado o Império, no art.163 da Carta Constitucional, outorgada em 25 de março de 1824, criou o Supremo Tribunal de Justiça, sendo que art. 164, inciso I estabelecia a competência para essa Corte "Conceder, ou denegar Revistas nas Causas, e pela maneira, que a Lei determinar."

Àquela altura, pelo sistema adotado, o Supremo Tribunal de Justiça, caso acolhesse a revista, determinava a volta do processo ao segundo grau de jurisdição (ou, eventualmente, para o primeiro, dependendo do momento em que tivesse ocorrido a grave nulidade que foi reconhecida), para, então, ser julgado o mérito do recurso. ${ }^{157}$

Esta foi a sistemática replicada em Portugal pelo mesmo Monarca, na reforma de 1832 , tal como se referiu ao final do item anterior.

Por certo que, no início do Império, foi necessária norma específica, a Lei de 20 de outubro de $1823^{158}$, pela qual se mantinha vigente toda a legislação herdada de Portugal, com destaque para as Ordenações, que previam a revista, tal como antes assinalado.

Pois bem, no Brasil, foi a Lei de 18 de setembro de 1828 que regulou o referido inciso I do art. 164 da Constituição de 1824, prevendo o cabimento das revistas "apenas num dos seguintes casos: manifesta nulidade ou injustiça nas sentenças proferidas em todos os juízos em última instância" (art. $6^{\circ}$ ), tal como lembra Estêvão Mallet ${ }^{159}$, segundo o qual, na prática:

\footnotetext{
${ }^{156}$ BRASIL. Constituição Política do Império do Brazil (de 25 de março de 1824). Disponível em: <http://www.planalto.gov.br/ccivil_03/Constituicao/Constituicao24.htm>. Acesso em: 25 de ago. 2010. Retomem-se as observações da nota de rodapé 148.

${ }^{157}$ Vide, a propósito, COSTA, Moacyr Lobo da. op. cit., p. 205-229, onde é feita minuciosa análise da evolução do recurso de revista no Direito Lusitano, sempre em paralelo com a ação de nulidade e rescisão, desde a metade do século XIX até o Código de 1962. Aqui, por certo, os antecedentes dos nossos atuais recursos de natureza extraordinária, o de revista trabalhista, o especial e o extraordinário, sem esquecer-se, no entanto, da gênese também comum da própria ação rescisória.

${ }^{158}$ Art. $1^{\circ}$ As Ordenações, Leis, Regimentos, Alvarás, Decretos, e Resoluções promulgadas pelos Reis de Portugal, e pelas quaes o Brazil se governava até o dia 25 de Abril de 1821, em que Sua Magestade Fidelissima, actual Rei de Portugal, e Algarves, se ausentou desta Côrte; e todas as que foram promulgadas daquella data em diante pelo Senhor D. Pedro de Alcantara, como Regente do Brazil, em quanto Reino, e como Imperador Constitucional delle, desde que se erigiu em Imperio, ficam em inteiro vigor na parte, em que não tiverem sido revogadas, para por ellas se regularem os negocios do interior deste Imperio, emquanto se não organizar um novo Codigo, ou não forem especialmente alteradas. SENADO FEDERAL. Lei de 20 de outubro de 1823. Disponível em: $<$ http://www6.senado.gov.br/legislacao/ListaPublicacoes.action?id=84601>. Acesso em: 25 de ago. 2010.

${ }^{159}$ MALLET, Estêvão. Do recurso de revista no processo do trabalho, cit., p. 27 , que transcreve trecho do art. 1611 da Consolidação das Leis do Processo Civil, de Antônio Joaquim Ribas. Vide, também, CRUZ E TUCCI, José Rogério. Jurisdição e poder, cit., p. 188-189, quando alude ao Código do Processo Criminal do Império, que continha normas recursais civis (art. 19, que trata da revista, deixando de existir o agravo ordinário).
} 
conforme demonstrou Pimenta Bueno, os dois casos reduziam-se a um só: "violação da lei e consequente nulidade do ato." Mas como a lei violada pode ser tanto a material como a processual, empregou o legislador da época duas expressões distintas, designando a ofensa à lei processual como "manifesta nulidade" e a ofensa à lei material como "injustiça notória" da sentença. ${ }^{160}$

O sempre lembrado (Regulamento) Decreto 737, de 25 de novembro de 1850, que disciplinava a ordem do juízo no processo comercial, previu a revista nos arts. 665 usque 667.

Este recurso era interposto para o Supremo Tribunal de Justiça contra as sentenças proferidas pelas Relações, observada alçada, sendo que a tramitação e o julgamento deveriam ocorrer do mesmo modo como se procedia nas causas cíveis.

As hipóteses de cabimento eram estritas: “Art. 667. O Supremo Tribunal de Justiça só concederá revista por nullidade do processo, ou por nullidade da sentença nos termos declarados no Tit. II Cap. I das nullidades"

As nulidades do processo ou as nulidades da sentença foram, também, taxativamente, enumeradas nos arts. 672 usque 681, sendo digna de nota a previsão de nulidade da sentença quando "proferida contra expressa disposição da legislação comercial" ${ }^{162}$, na exata forma do $\S 2^{\circ}$ do art. 680 do Decreto 737.

Como se viu, praticamente até o fim do Império do Brasil e, de forma explícita, no início da República, permaneceram em vigor as leis do "antigo regime", vale dizer, as Ordenações Filipinas e Leis posteriores, que nelas não estavam inseridas, tal como veio a ser consignado no art. $80{ }^{163}$ daquela que se pode dizer "Constituição Provisória", emanada do Governo Provisório Republicano, ou seja, o Decreto nº510, de 22 de junho de 1890.

\footnotetext{
${ }^{160}$ MALLET, Estêvão. Do recurso de revista no processo do trabalho, cit.

${ }^{161}$ Transcrição de trecho original do Decreto $\mathrm{n}^{\circ} 737$, de 25 de novembro de 1850 , encontrável no sítio BRASIL. Decreto n. 737, de 25 de novembro de 1850. Disponível em: <http://www.planalto.gov.br/ccivil_03/decreto/Historicos/DIM/DIM737.htm>. Acesso em: 25 ago. 2010.

${ }^{162} \mathrm{Na}$ forma da nota de rodapé anterior.

${ }^{163}$ Art. 80. Continuam em vigor, emquanto não revogadas, as leis do antigo regime, no que explicita ou implicitamente não for contrario ao systema de governo firmado pela Constituição e aos principios nella consagrados. SENADO FEDERAL. Decreto n. 510, de 22 de junho de 1890. Disponível em: <http://www6.senado.gov.br/legislacao/ListaPublicacoes.action?id=91702>. Acesso em: 20 ago. 2010.
} 
Essa idêntica diretriz, por óbvio, constou, afinal, do art. 83 da própria Constituição de $1891 .^{164}$

E, tendo em conta os recursos de natureza extraordinária e, em especial, os primórdios do recurso de revista trabalhista, ${ }^{165}$ há de ser reforçada a invocação do Decreto $\mathrm{n}^{\circ} 510$, de 22 de junho de 1890, pois, ainda que se tratasse de esboço ou de projeto de Constituição, que seria "julgado" (assim foi posto no decreto) pelo "primeiro Congresso Nacional dos representantes do povo brasileiro", a ser eleito em 15 de setembro daquele ano, todavia, entrava "em vigor desde já nos pontos submetidos abaixo especificados"166, dentre eles os que tratavam do Poder Judiciário (arts. 54 usque 61).

E foi no art. 58 inciso III que veio definida a competência para o Supremo Tribunal Federal rever os julgamentos oriundos das Justiças dos Estados Federados, “a)quando se questionar a "validade ou aplicabilidade de tratados e leis federais, e a decisão do tribunal do Estado for contra ela", e, "b) quando se contestar a validade de leis ou atos dos governos dos Estados em face da Constituição ou das leis federais e a decisão do tribunal do Estado considerar válidos os atos, ou as leis impugnados"

Ainda desse notável Decreto se extrai, pela primeira vez, explícita alusão à jurisprudência, pois o $\S 2^{\circ}$ ("rectius" $\S 1^{\circ}$ ) desse mesmo art. 58 estabelecia que, "nos casos em que houver de aplicar leis dos Estados, a justiça federal consultará a jurisprudência dos tribunais locais; e vice-versa, a justiça dos Estados consultará a jurisprudência dos tribunais federais, quando houver de interpretar leis da União." 168

Estêvão Mallet ${ }^{169}$ viu nesse Decreto $\mathrm{n}^{\circ}$ 510, de 22 de junho de 1890, nítida inspiração do Judiciary Act norte-americano, de 1789, pois, em ambas situações históricas,

\footnotetext{
${ }^{164}$ Art 83 - Continuam em vigor, enquanto não revogadas, as leis do antigo regime no que explícita ou implicitamente não forem contrárias ao sistema do Governo firmado pela Constituição e aos princípios nela consagrados. BRASIL. Constituição da República dos Estados Unidos do Brasil (de 24 de fevereiro de 1891). Disponível em: <http://www.planalto.gov.br/ccivil_03/Constituicao/Constituicao91.htm>. Acesso em: 25 ago. 2010.

${ }^{165}$ Repita-se que, até aquele momento, a idéia de revista englobava, tanto o atual recurso extraordinário para o STF, como a ação rescisória e a revisão criminal. Nessa revista estão os embriões dos futuros recursos de revista trabalhista e o especial, com destaque para a hipótese de violação de preceito de lei federal.

${ }^{166}$ Tudo conforme transcrição de trechos do referido Decreto $n^{\circ} 510$, de 22 de junho de 1890, acessado na forma da nota de rodapé número 163.

${ }^{167}$ Tudo conforme transcrição de trechos do referido Decreto $\mathrm{n}^{\circ} 510$, de 22 de junho de 1890, acessado na forma da nota de rodapé número 163.

${ }^{168}$ Tudo conforme transcrição de trechos do referido Decreto $n^{\circ} 510$, de 22 de junho de 1890, acessado na forma da nota de rodapé número 163.

${ }^{169}$ MALLET, Estêvão. Do recurso de revista no processo do trabalho, cit., p. 26-27.
} 
uma vez implantada a Federação, haveria de ser respeitada a supremacia da Constituição Federal e, também, das leis federais, em confronto com aquelas dos Estados Membros, por isso que se fazia necessário o controle dessa prevalência do ordenamento nacional, através de um recurso de revisão (art. 58,III, “b”), cujo julgamento, no Brasil, era atribuído ao Supremo Tribunal Federal. ${ }^{170}$

O Generalíssimo Manoel Deodoro da Fonseca, chefe do Governo Provisório da República, três meses depois, também baixou o Decreto nº 848, de 11 de outubro de 1890, que organizava a Justiça Federal "exercida por um Supremo Tribunal Federal e por juizes inferiores intitulados - Juizes de Secção" ${ }^{\prime 171}$, tal como rezava o art. $1^{\circ}$ dessa lei decretada. O art. $3^{\circ}$ dava a tônica federativa ao atribuir à Magistratura Federal "a guarda e applicação da Constituição e das leis nacionaes"172, desde que houvesse provocação das partes.

Em sintonia com a Constituição Provisória, referido Decreto $n^{\circ} 848$ tratou de toda a competência do Supremo Tribunal Federal no art. $9^{\circ}$, sendo certo que o respectivo parágrafo único já aludia a um recurso que se destinaria a preservar Constituição e a legislação federal. ${ }^{173}$

A Constituição de 1891 não se distanciou do esboço apresentado e já vigorante desde o ano anterior.

Na definição da competência recursal do Supremo Tribunal Federal, no $§ 1^{\circ}$ do art. 60 , foi estabelecido que

\footnotetext{
${ }^{170}$ Sob esse prisma, tal como visto na evolução histórica dos recursos, trata-se da mesma idéia motriz de preservação da autoridade do Príncipe ou do Monarca, de quem emanavam as leis, o que, na República Federativa, localiza-se nas assembléias estaduais e na nacional, com predomínio desta, de acordo com as competências definidas pela Constituição Federal. Trata-se do início do controle difuso de constitucionalidade, assim como o da legalidade (que, nalguma medida já existia), feito por qualquer magistrado, mas cuja última palavra estaria a cargo do Supremo Tribunal Federal.

${ }^{171}$ Transcrição de trechos originais do Decreto ${ }^{\circ} 848$, de 11 de outubro de 1890, extraídas do sítio SENADO FEDERAL. Decreto n. 848, de 11 de outubro de 1890. Disponível em: <http://www6.senado.gov.br/legislacao/ListaPublicacoes.action?id=66054>. Acesso em: $1^{\circ}$ set. 2010.

${ }^{172} \mathrm{Na}$ mesma forma da nota de rodapé anterior.

${ }^{173}$ Art. $9^{\circ}$. Paragrapho unico. Haverá tambem recurso para o Supremo Tribunal Federal das sentenças definitivas proferidas pelos tribunaes e juizes dos Estados:

a) quando a decisão houver sido contraria á validade de um tratado ou convenção, á applicabilidade de uma lei do Congresso Federal, finalmente, á legitimidade do exercicio de qualquer autoridade que haja obrado em nome da União - qualquer que seja a alçada;

b) quando a validade de uma lei ou acto de qualquer Estado seja posta em questão como contrario á Constituição, aos tratados e ás leis federaes e a decisão tenha sido em favor da validade da lei ou acto;

c) quando a interpretação de um preceito constitucional ou de lei federal, ou da clausula de um tratado ou convenção, seja posta em questão, e a decisão final tenha sido contraria, á validade do titulo, direito e privilegio ou isenção, derivado do preceito ou clausula. Transcrição feita na forma da nota de rodapé 172.
} 
Das sentenças das Justiças dos Estados, em última instância, haverá recurso para o Supremo Tribunal Federal: a) quando se questionar sobre a validade, ou a aplicação de tratados e leis federais, e a decisão do Tribunal do Estado for contra ela; b) quando se contestar a validade de leis ou de atos dos Governos dos Estados em face da Constituição, ou das leis federais, e a decisão do Tribunal do Estado considerar válidos esses atos, ou essas leis impugnadas. ${ }^{174}$

Também não foi esquecida a jurisprudência:

$\S 2^{\circ}$ - Nos casos em que houver de aplicar leis dos Estados, a Justiça Federal consultará a jurisprudência dos Tribunais locais, e vice-versa, as Justiças dos Estados consultarão a jurisprudência dos Tribunais Federais, quando houverem de interpretar leis da União. ${ }^{175}$

Disso tudo se extrai a conclusão no sentido de que o Tribunal de ápice do Poder Judiciário Brasileiro haveria de rever ou deveria julgar recurso (até, então, sem denominação própria) no qual se discutisse, exclusivamente e em síntese, a prevalência da Constituição Federal sobre as Constituições Estaduais e da legislação federal sobre a local, com a recomendação constitucional de observância da jurisprudência, conforme o caso ${ }^{176}$.

Não se pode olvidar, todavia, conforme observou Mozart Victor Russomano, ${ }^{177}$ que o novel regime republicano, a exemplo do que já ocorrera com o Regulamento 737 de 1850, que consagrava rito processual sumário para ações resultantes do trabalho, editou a primeira medida legislativa nessa perspectiva, qual seja, o Decreto n. 1637, de 5 de janeiro de 1907, cujo art. $8^{\circ}$ dispôs sobre os Conselhos Permanentes de Conciliação e Arbitragem,

\footnotetext{
${ }^{174}$ Transcrição feita na forma da nota de rodapé número 164.

${ }^{175}$ Transcrição feita na forma da nota de rodapé número 164.

${ }^{176}$ Há candente discussão doutrinária a respeito da origem do recurso extraordinário, como se pode ver em CÔRTES, Osmar Mendes Paixão. Recurso extraordinário: origem e desenvolvimento no direito brasileiro. Rio de Janeiro: Forense, 2005. p.74-95 e 187-198, o qual sustenta que "há uma certa afinidade dentre esses recursos e o recurso extraordinário, o que não significa que este tenha sido uma evolução daqueles", ou seja, suplicação (agravo ordinário), ligando, portanto, o recurso extraordinário ao direito americano, como o fizeram Pontes de Miranda e José Afonso da Silva, por ele citados. Não sendo o escopo deste trabalho adentrar nesta polêmica, há de se destacar, porém, que este autor, tal como se constata da bibliografia indicada à p.290, não cita Moacyr Lobo da Costa, Luiz Carlos de Azevedo nem José Rogério Cruz e Tucci, os quais, como exaustivamente demonstrado, dão notícia da evolução histórica dos recursos de natureza extraordinária, desde Roma, passando pela península Ibérica, até esta parte. De qualquer sorte, a ligação do recurso de revista com a tradição recursal lusitana é marcante pelo escopo de preservação da lei e da uniformidade da jurisprudência.

${ }^{177}$ RUSSOMANO, Mozart Victor. Direito processual do trabalho. São Paulo: LTr, 1977. p. 171.
} 
antes, portanto, das experiências paulistas visando a composição dos conflitos entre trabalhadores rurais e os proprietários ${ }^{178}$.

Carlos Mário da Silva Velloso, em discurso que proferiu na comemoração dos $175^{\circ}$ aniversário do Supremo Tribunal Federal, bem demonstrou a diferença de atuação entre o Supremo Tribunal de Justiça do Império e o Supremo Tribunal Federal, pois, malgrado o Poder Judicial tenha sido concebido como poder do Estado, na prática o Poder Moderador, exercido pelo Imperador, impediu que o Supremo

exercesse com largueza, a função jurisdicional. Ademais, por influência do constitucionalismo francês, o controle de constitucionalidade das lei, na Carta Imperial, era do próprio Poder Legislativo. Limitava-se o Judiciário, então, a dirimir os conflitos entre os particulares. Bem por isso, assinalou o Ministro Trigueiro, que "o Supremo era, tipicamente, uma Corte de Cassação, no exato estilo europeu. Praticamente a sua competência se exauria na função de conceder revista, para o efeito de determinar que a causa fosse novamente julgada por outra Relação", ${ }^{179}$

De fato, como se disse antes, quando se aludiu ao despontar da jurisprudência e sua trajetória até, por exemplo, a criação dos assentos da Casa da Suplicação, em momentos de hegemonia do poder central havia uma surda luta entre força jurisprudencial e a aplicação das leis, ${ }^{180}$ que muitos desejavam ser meramente literal, para que não fosse infirmada a autoridade do Imperador e, depois, do Legislativo que as fazia.

Este fenômeno já havia sido ressaltado por Estêvão Mallet quando aludiu à supervisão, estrita e rígida, que, no modelo pós revolução francesa, era exercida pela Corte de Cassação sobre a atividade jurisdicional, vedando interpretação que não fosse a mais próxima da literalidade da lei, sem poder construtivo algum do julgador. ${ }^{181}$

\footnotetext{
${ }^{178}$ Decreto n. 1.637 obtido junto ao sítio de legislação do Senado Federal. SENADO FEDERAL. Decreto n. 1637, de 5 de janeiro de $1907 . \quad$ Disponível em: $<$ http://www6.senado.gov.br/legislacao/ListaPublicacoes.action?id=55323\&tipoDocumento=DEC\&tipoTe xto=PUB $>$. Acesso em: 01 dez 2010.

${ }^{179}$ Inteiro teor do discurso publicado no DJU de 2/10/2003, no 190, Primeira Seção, p. 63-65, obtido no sítio SUPREMO TRIBUNAL FEDERAL. Diário da Justiça. Disponível em: <http://www.stf.jus.br/arquivo/biblioteca/PastasMinistros/CarlosVelloso/Discursos/Proferidos/042.pdf>. Acesso em: $1^{\circ}$ set. 2010.

${ }^{180} \mathrm{Cfr}$. supra p. 26 e ss.

${ }^{181}$ MALLET, Estêvão. Do recurso de revista no processo do trabalho, cit., p. 26.
} 
A pouco e pouco, no entanto, veio se afirmando a atuação do Poder Judiciário, mormente na principiante República, sendo oportuno, uma vez mais, retomar as considerações e a síntese feita por Carlos Mário da Silva Velloso:

Em conferência pronunciada em 1952, consignou o saudoso e eminente Miguel Seabra Fagundes: "Vínhamos, em 1891, do Império, onde a Justiça não tinha nenhuma expressão política. Era um poder que se limitava a dirimir as controvérsias de direito privado, de modo que os Atos da Administração pública escapavam, por inteiro, ao seu controle. E, de chofre, pela instituição da República, o Poder Judiciário foi elevado ao plano de excepcional importância na vida política do país. Atribui-selhe, ao lado da função que já era sua, de dirimidor das questões de ordem privada, uma outra, da maior importância: a de guardar os direitos individuais contra as infrações decorrentes de atos do Poder Executivo e do Poder Legislativo, inclusive e notadamente quando esses atos afetassem textos constitucionais. Isso equivalia, de certo modo, a fazê-lo fiador da seriedade do regime como construção política, pois ao declarar a prevalência da Lei Suprema em face de atos legislativos ou administrativos que a afetavam, o que fazia o Judiciário era preservar as próprias instituições republicanas, pela contenção dos demais poderes nas suas órbitas estritas de ação e pela garantia ao indivíduo da sobrevivência dos seus direitos, fossem quais fossem as prevenções contra eles armadas" 182

Foi a Constituição de 1934 que, pela primeira vez, ao tratar da competência do Supremo Tribunal Federal (art. 76), explicitamente menciona a ação rescisória (número 2, inciso I), passa a denominar "recurso extraordinário" o remédio constitucional específico para preservar a Carta Magna e a legislação federal e, ainda, de forma inédita e específica, atribui à Corte Suprema o mister de unificar eventual jurisprudência, que fosse conflitante com a sua, seja originada dos Tribunais Estaduais, seja de qualquer outro Tribunal Federal. ${ }^{183}$

\footnotetext{
${ }^{182} \mathrm{Na}$ forma da nota rodapé de número 178.

${ }^{183}$ (Art. 76, 2) Julgar: III) - em recurso extraordinário, as causas decididas pelas Justiças locais em única ou última instância:

a) quando a decisão for contra literal disposição de tratado ou lei federal, sobre cuja aplicação se haja questionado;

b) quando se questionar sobre a vigência ou validade de lei federal em face da Constituição, e a decisão do Tribunal local negar aplicação à lei impugnada;

c) quando se contestar a validade de lei ou ato dos Governos locais em face da Constituição, ou de lei federal, e a decisão do Tribunal local julgar válido o ato ou a lei impugnada;

d) quando ocorrer diversidade de interpretação definitiva da lei federal entre Cortes de Apelação de Estados diferentes, inclusive do Distrito Federal ou dos Territórios, ou entre um deste Tribunais e a Corte Suprema, ou outro Tribunal federal. Texto original extraído do sítio BRASIL. Constituição da República dos Estados Unidos do Brasil (de 16 de julho de 1934). Disponível em: <http://www.planalto.gov.br/ccivil_03/Constituicao/Constituicao34.htm>. Acesso em: $1^{\circ}$ set. 2010.
} 
Salvo pequenas alterações, a Carta Outorgada de 1937 não fez significativas mudanças na competência recursal extraordinária do Supremo Tribunal Federal, de sorte que o art. 101, III, manteve a busca da prevalência da Constituição e da Lei Federal, assim como a da jurisprudência da Corte Suprema, obstando "inteligência diversa."184

Foi sob essa Carta, que a Justiça do Trabalho veio a ser organizada, por força do Decreto no 1237, de 02 de maio de 1939, cujo art. $2^{\text {o, }}$ letras "a", "b" e "c" criou, respectivamente, as Juntas de Conciliação e Julgamento, os Conselhos Regionais do Trabalho e o Conselho Nacional do Trabalho. ${ }^{185}$

A partir daqui passamos a tratar do recurso extraordinário do processo do trabalho, o recurso de revista, sem descurar, portanto, as influências daquele recurso que era processado, de início, só perante a Suprema Corte, o que gerou ao longo do século XX e permanece neste aquilo que se convencionou dizer a crise do recurso extraordinário, conforme demonstraram Gilmar Ferreira Mendes, Inocêncio Mártires Coelho e Paulo Gustavo Gonet Branco, ${ }^{186}$ o que não discrepa do que se dá com o recurso trabalhista.

Notável considerar, no entanto, que aquele Decreto 1237/39, ao abordar os recursos possíveis no seu art. 73 , já exigia tratar-se de decisão definitiva, consagrava a regra geral do efeito recursal meramente devolutivo, assim como o de que a execução provisória se daria até a penhora, além de prever a necessidade do depósito recursal prévio, até um determinado valor.

E mais: o recurso para o Conselho Nacional, ou seja, para o órgão de cúpula da Justiça do Trabalho, nasceu só por divergência jurisprudencial (g.n.). Veja-se o teor da previsão legal:

\footnotetext{
${ }^{184}$ (Art. 101) III - julgar, em recurso extraordinário, as causas decididas pelas Justiças locais em única ou última instâncias:

a) quando a decisão for contra a letra de tratado ou lei federal, sobre cuja aplicação se haja questionado;

b) quando se questionar sobre a vigência ou validade da lei federal em face da Constituição, e a decisão do Tribunal local negar aplicação à lei impugnada;

c) quando se contestar a validade de lei ou ato dos Governos locais em face da Constituição, ou de lei federal, e a decisão do Tribunal local julgar válida a lei ou o ato impugnado;

d) quando decisões definitivas dos Tribunais de Apelação de Estados diferentes, inclusive do Distrito Federal ou dos Territórios, ou decisões definitivas de um destes Tribunais e do Supremo Tribunal Federal derem à mesma lei federal inteligência diversa. Texto original extraído do sítio BRASIL. Constituição dos Estados Unidos do Brasil (de 10 de novembro de 1937). Disponível em: <http://www.planalto.gov.br/ccivil_03/Constituicao/Constituicao37.htm>. Acesso em: $1^{\circ}$ set. 2010.

${ }^{185} \mathrm{Faz}$-se aqui um corte expositivo, deixando-se de lado o recurso extraordinário do Supremo Tribunal Federal e buscando-se a trilha do recurso que se transformou na revista do processo do trabalho.

${ }^{186}$ MENDES, Gilmar Ferreira; COELHO, Inocêncio Mártires; BRANCO, Paulo Gustavo Gonet. Curso de direito constitucional. 3. ed. São Paulo: Saraiva, 2008. p. 957-959.
} 
Art. 76. Quando a decisão do conselho Regional der á mesma lei inteligência diversa da que tiver sido dada por outro Conselho ou pelo Conselho Nacional do Trabalho, caberá recurso para este.

Parágrafo único. O recurso terá efeito devolutivo, salvo ao presidente do tribunal, no caso de. divergência manifesta, dar-lhe, também efeito suspensivo. ${ }^{187}$

Este recurso trabalhista, até então sem nome, passou a ser chamado "recurso extraordinário", por força do art. 203 do Decreto n 6596, de 12 de dezembro de $1940{ }^{188}$, o qual aprovou o Regulamento da Justiça do Trabalho. E, sob o ponto de vista da denominação, não se houve muito bem o legislador, pois, abriu chance para dúvidas e malentendidos na medida em que a Constituição de 1937, tal como acima relatado, já havia previsto recurso extraordinário para o Supremo Tribunal Federal.

Esse conflito terminológico (que, num determinado momento, ver-se-á, também ocorreu com o recurso de revista) mereceu apropriada observação Mozart Victor Russomano, ${ }^{189}$ pois, até a metade da década de 40, malgrado a aparência, "a jurisdição do trabalho, no Brasil, nasceu como instância administrativa ou, pelo menos, foi ela assim considerada", tendo figurado no capítulo da Ordem Econômica nas Cartas de 1934 e 1937, de sorte que a natureza administrativa de suas decisões "constituiu a causa pela qual o recurso extraordinário não foi admitido nas ações trabalhistas, quer pela doutrina, quer pela jurisprudência do Supremo Tribunal Federal, (g.n.)" o que só foi superado depois da constitucionalização do Judiciário Trabalhista, ocorrida depois, com a Carta Política de 1946 .

Antônio Álvares da Silva, ao delinear a história do recurso de revista e também reportando-se aos ensinamentos de Pimenta Bueno, sustenta que esse apelo deveria

\footnotetext{
${ }^{187}$ SENADO FEDERAL. Decreto-Lei n. 1.237 , de 02 de maio de 1939. Disponível em: <http://www6.senado.gov.br/legislacao/ListaPublicacoes.action?id=8115>. Acesso em: $1^{\circ}$ set. 2010.

${ }^{188}$ Art. 203. Cabe recurso extraordinário das decisões, proferidas em única ou última instância pelos Conselhos Regionais, que derem à mesma lei interpretação diversa da que tiver sido dada por outro Conselho Regional ou pela Câmara de Justiça do Trabalho ou, ainda, pelo Conselho Nacional do Trabalho, na plenitude de sua composição. O teor desde artigo só foi obtido no sítio do TRT da $1^{\text {a }}$ Região: TRIBUNAL REGIONAL DO TRABALHO 1ª REGIÃO. Decreto n. 6.596 - de 12 de dezembro de 1940. Disponível em: $<$ http://portal2.trtrio.gov.br:7777/portal/page?_pageid=73,5714538\&_dad=portal\&_schema=PORTAL>. Acesso em: $1^{\circ}$ set. 2010.

${ }^{189}$ RUSSOMANO, Mozart Victor. Direito processual do trabalho, cit., p. 170-178.
} 
“continuar sendo designado por recurso extraordinário, para deixar claro sua função diferenciada do ordinário que se interpõe da primeira para a segunda instância." 190

Certo é que, sobrevindo a Consolidação das Leis do Trabalho, aprovada pelo Decreto-lei 5452, de $1^{\circ}$ de maio de 1943, o art. 893, inciso III, manteve a denominação de recurso extraordinário para aquele que fosse interposto perante o Órgão de Cúpula da IJustiça do Trabalho. As hipóteses de cabimento (agora, duas) estavam no art. 896 letras "a", isto é, "derem à mesma norma jurídica interpretação diversa da que tiver sido dada por um Conselho Regional ou pela Câmara da Justiça do Trabalho") e "b", "proferidas com violação expressa (g.n.)de direito". Logo, porém, esta letra "b" foi modificada pelo Decreto-lei 6353, de 20 de março de 1944, que, dizendo fazer correições (sic), transformou-a em "proferidas com violação de norma jurídica". ${ }^{191}$

O alargamento do cabimento da revista, agora, por violação de norma jurídica não parou aí; malgrado o Decreto-lei ${ }^{\circ}$ 8737, de 19 de janeiro de 1946, tenha iniciado uma qualificação ou especificidade para o tipo de infringência, isto é, contra decisões “proferidas contra a letra expressa de lei”, ${ }^{192}$ já a Lei no 861, de 13 de outubro de 1949, descarta essa singularidade e retoma a tônica de ampliação do espectro de violação, ou seja, volta a "violação de norma jurídica" e, ainda, acrescentam-se os "princípios gerais de direito",193

Foi a Lei $n^{\circ} 861 / 49$ que definiu o nome "recurso de revista", afastando qualquer possibilidade de confusão com o recurso extraordinário, agora exclusivo para o Supremo Tribunal Federal, nos termos do art. 101,III, da Carta de $1946 .{ }^{194}$

Manoel Antonio Teixeira Filho relata que a "doutrina sempre manifestou opinião crítica a essa inovação, sob o argumento de que a antiga nomenclatura era mais adequada

\footnotetext{
${ }^{190}$ SILVA, Antônio Álvares. O novo recurso de revista na justiça do trabalho. São Paulo: LTr, 1999. p. 3038.

${ }^{191}$ BRASIL. Decreto-Lei n. 5.452, de $1^{\text {o }}$ de maio de 1943. Disponível em: <http://www.planalto.gov.br/ccivil_03/Decreto-Lei/Del5452.htm>. Acesso em: $1^{\circ}$ set. 2010.

${ }^{192}$ BRASIL. Decreto-Lei n. 8.737, de 19 de janeiro de 1946. Disponível em: <http://www.planalto.gov.br/ccivil_03/Decreto-Lei/Del8737.htm>. Acesso em: $1^{\text {o }}$ set. 2010.

${ }^{193}$ BRASIL. Lei n. 861, de outubro de 1949. Disponível em: <http://www.planalto.gov.br/ccivil_03/Leis/L0861.htm>. Acesso em: 8 set. 2010.

${ }^{194}$ BRASIL. Constituição dos Estados Unidos do Brasil (de 18 de setembro de 1946). Disponível em: <http://www.planalto.gov.br/ccivil_03/Constituicao/Constituicao46.htm>. Acesso em: 08 set. 2010.
} 
para indicar a natureza e finalidade do remédio em exame, cujo caráter extraordinário estava em que o seu objetivo era apenas impugnar matéria jurídica."195

Tanto este Jurista ${ }^{196}$, como Mozart Victor Russomano, ${ }^{197}$ concordaram que era inadequada a nomenclatura "extraordinário" porque, afinal, esse recurso era julgado no próprio âmbito da Justiça do Trabalho, não se deslocando para órgão diverso, como é o Supremo Tribunal Federal, crítica com a qual não concorda Antônio Álvares da Silva, inclusive mais recentemente, tal como antes referido, pois ele insiste em que seria mais importante dar destaque para a natureza extraordinária do recurso de revista. ${ }^{198}$

A mudança para o nomen juris recurso de revista teria sido preponderantemente justificada porque haveria a possibilidade de serem interpostos no mesmo processo dois recursos extraordinários, ou seja, um do Tribunal Regional para o Superior e "o segundo, do Tribunal Superior para o Supremo Tribunal Federal."199

Há de se convir, todavia, que a índole extraordinária do recurso de revista, tal como se tem procurado demonstrar pela trajetória histórica dessa espécie de apelo, não decorre, fundamentalmente, da definição do órgão do Poder Judiciário que irá apreciá-lo de forma integral ou completa, mas, afora requisitos prévios (v.g. depósito), repita-se, decorre da excepcionalidade das hipóteses de sua interposição, legalmente definidas e restritas, de modo que sempre haverá discussão do direito em tese, cuja aplicação uniforme e cuja predominância há de ser buscada e preservada, mormente no regime federativo.

Na discussão e na preservação do direito (em tese) é que reside a semelhança do recurso de revista trabalhista com aquela revista imperial.

Também na busca da uniformidade de interpretação das leis, ou seja, na unificação da jurisprudência é que havia similitude entre a revista trabalhista e o recurso de mesmo nome, previsto no art. 853 do Código de Processo Civil de 1939, tal como ensinava Mozart

\footnotetext{
${ }^{195}$ TEIXEIRA FILHO, Manoel Antonio. Sistema dos recursos trabalhistas. São Paulo: LTr, 1989. p. 189.

${ }^{196}$ Id. Ibid.

${ }^{197}$ RUSSOMANO, Mozart Victor. Comentários à Consolidação das Leis do Trabalho, cit., v. 5, p. 1568.

${ }^{198} \mathrm{Cfr}$. supra p. 50-51 e nota de rodapé 186.

${ }^{199}$ RUSSOMANO, Mozart Victor. Comentários à Consolidação das Leis do Trabalho, cit., v. 5, p. 1568.
} 
Victor Russomano, ${ }^{200}$ ressaltando-se, todavia, que nesse último caso, a uniformização era exclusivamente dentro da mesma Corte.

Afinal, a ambiguidade de nomenclatura entre o recurso de revista trabalhista e o do processo civil só foi superada com a promulgação do atual Código de Processo Civil, do ano de 1973, que eliminou essa espécie recursal civil.

Para melhor compreensão da hipótese de cabimento do recurso de revista por divergência (inteligência diversa, interpretação diversa), veja-se o primeiro quadro abaixo:

$$
\text { QUADRO I }{ }^{201}
$$

\begin{tabular}{|l|l|}
\hline $\begin{array}{l}\text { der à mesma lei inteligência diversa da que tiver } \\
\text { sido dada por outro Conselho ou pelo Conselho } \\
\text { Nacional do Trabalho }\end{array}$ & $\begin{array}{l}\text { Art. } 76 \text { do Decreto }{ }^{\circ} \text { 1237/ } 39 . \\
\text { (chamava-se recurso extraordinário) }\end{array}$ \\
\hline $\begin{array}{l}\text { der à mesma lei interpretação diversa da que } \\
\text { tiver sido dada por outro Conselho Regional ou } \\
\text { pela Câmara de Justiça do Trabalho ou, ainda, } \\
\text { pelo Conselho Nacional do Trabalho, na } \\
\text { plenitude de sua composicão }\end{array}$ & Art. 203 do Decreto no 6596/40. \\
\hline $\begin{array}{l}\text { (ainda chamado recurso extraordinário) } \\
\text { diversa da que tiver sido dada por um Conselho } \\
\text { Regional ou pela Câmara da Justiça do } \\
\text { Trabalho. }\end{array}$ & $\begin{array}{l}\text { Art. 896, "a" do Decreto-lei no 5452/43, que } \\
\text { aprovou a CLT. }\end{array}$ \\
$\begin{array}{l}\text { (ainda chamado recurso extraordinário) } \\
\text { (N.B. a partir de então, surge a segunda hipótese } \\
\text { de cabimento da revista: por violação de lei. }\end{array}$ \\
\hline $\begin{array}{l}\text { a) derem à mesma norma, jurídica interpretação } \\
\text { diversa da que tiver sido dada por um Conselho }\end{array}$ & $\begin{array}{l}\text { Art. 896, "a" da CLT, com a redação dada pelo } \\
\text { Decreto-lei no 8737/46. }\end{array}$ \\
\hline
\end{tabular}

${ }^{200}$ RUSSOMANO, Mozart Victor. Comentários à Consolidação das Leis do Trabalho, cit., v. 5, p. 1569. Há de se deixar claro que, a partir da Lei 9756/98, que empresta forma à atual redação da letra "a" do art. 896 da CLT(a. D.2010), não pode mais ser invocada divergência oriunda do mesmo Tribunal Regional do Trabalho, exigindo-se que seja de outro Tribunal Regional. Bem por isso o legislador procurou impor uma solução para as divergências intestinas das Cortes. Assim sendo, a uniformização interna da jurisprudência (há muito tempo preconizada no art. 14 da Lei $7701 / 88$ e, agora, obrigatória pelo $\$ 3^{\circ}$ do art. 896) deve ser feita por meio do Incidente de Uniformização disciplinado pelo CPC, abrangendo interpretação de leis, inclusive estaduais, assim como de normas coletivas. No âmbito do TRT da $15^{\text {a }}$ Região está previsto nos arts. 192 usque 195, mas, pode-se atestar, que seu uso é raríssimo. Aqui estaria, segundo alguns, um sério problema que merece ser melhor discutido e solucionado, com vistas à diminuição dos recursos que sobem ao TST. Ele está abordado no anteprojeto de lei a ser encaminhado pelo TST, tal como definido pela última Comissão da Transcendência do recurso de revista, o que se verá mais abaixo, item 4.3.

${ }^{201}$ Quadro elaborado a partir das informações legislativas extraídas do sítio da Palácio do Planalto, BRASIL. Decreto-Lei n. 5.452, de $1^{\text {o }}$ de maio de 1943. Disponível em: <http://www.planalto.gov.br/ccivil_03/Decreto-Lei/Del5452.htm>. Acesso em: $1^{\text {o }}$ set. 2010. 


\begin{tabular}{|c|c|}
\hline $\begin{array}{l}\text { Regional ou pelo Conselho Nacional do } \\
\text { Trabalho. }\end{array}$ & (ainda chamado recurso extraordinário) \\
\hline $\begin{array}{l}\text { a) derem à mesma norma jurídica interpretação } \\
\text { diversa da que tiver sido dada pelo mesmo } \\
\text { Tribunal Regional ou pelo Tribunal Superior } \\
\text { do Trabalho. }\end{array}$ & $\begin{array}{l}\text { Art. 896, "a" da CLT, com a redação dada pela } \\
\text { Lei no } 861 / 49 \text {. }\end{array}$ \\
\hline $\begin{array}{l}\text { a) derem ao mesmo dispositivo legal } \\
\text { interpretação diversa da que tiver sido dada pelo } \\
\text { mesmo ou por outro Tribunal Regional ou } \\
\text { pelo Tribunal Superior do Trabalho, na } \\
\text { plenitude de sua composicão; }\end{array}$ & $\begin{array}{l}\text { Art. 896, "a" da CLT, com a redação dada pela } \\
\text { Lei n 2244/54. }\end{array}$ \\
\hline $\begin{array}{l}\text { I) derem ao mesmo dispositivo legal } \\
\text { interpretação diversa da que tiver sido dada pelo } \\
\text { Tribunal Regional ou pelo Tribunal Superior } \\
\text { do Trabalho, na plenitude de sua composição, } \\
\text { salvo se a decisão recorrida estiver em } \\
\text { consonância com prejulgado } \\
\text { jurisprudência uniforme dêste; }\end{array}$ & $\begin{array}{l}\text { Art. 896, inciso I. da CLT, com a redação dada } \\
\text { pela Decreto-lei no } 229 / 67 \text {. }\end{array}$ \\
\hline $\begin{array}{l}\text { a) derem ao mesmo dispositivo legal a } \\
\text { interpretação diversa da que lhe houver dado o } \\
\text { mesmo ou outro Tribunal Regional, através do } \\
\text { Pleno ou de Turma, ou o Tribunal Superior do } \\
\text { Trabalho, em sua composição plena, salvo se a } \\
\text { decisão recorrida estiver em consonância com } \\
\text { prejulgado ou jurisprudência uniforme dêste; }\end{array}$ & $\begin{array}{l}\text { Art. 896, "a", da CLT, na forma da redação dada } \\
\text { pela Lei no } 5442 / 68 \text {. }\end{array}$ \\
\hline $\begin{array}{l}\text { a) derem ao mesmo dispositivo legal } \\
\text { interpretação diversa da que lhe houver dado o } \\
\text { mesmo ou outro Tribunal Regional, através do } \\
\text { Pleno ou de Turmas, ou o Tribunal Superior do } \\
\text { Trabalho, em sua composição plena, salvo se a } \\
\text { decisão recorrida estiver em consonância com } \\
\text { súmula de jurisprudência uniforme deste." }\end{array}$ & $\begin{array}{l}\text { Art. 896, "a", da CLT, na forma da redação dada } \\
\text { pela Lei no 7033/82. }\end{array}$ \\
\hline $\begin{array}{l}\text { a) derem ao mesmo dispositivo de lei federal } \\
\text { interpretação diversa da que lhe houver dado o } \\
\text { mesmo ou outro Tribunal Regional, através do } \\
\text { Pleno ou de Turmas, ou a Seção de Dissídios } \\
\text { Individuais do Tribunal Superior do Trabalho, } \\
\text { salvo se a decisão recorrida estiver em }\end{array}$ & $\begin{array}{l}\text { Art. 896, "a", da CLT, na forma da redação dada } \\
\text { pela Lei no } 7701 / 88 .\end{array}$ \\
\hline
\end{tabular}




\begin{tabular}{|c|c|}
\hline $\begin{array}{l}\text { consonância com enunciado da Súmula de } \\
\text { Jurisprudência Uniforme do Tribunal } \\
\text { Superior do Trabalho; } \\
\text { b) derem ao mesmo disposto de lei estadual, } \\
\text { Convenção Coletiva de Trabalho, Acordo } \\
\text { Coletivo, sentença normativa ou regulamento } \\
\text { empresarial de observância obrigatória em área } \\
\text { territorial que exceda a jurisdição do Tribunal } \\
\text { Regional prolator interpretação divergente, na } \\
\text { forma da alínea a; }\end{array}$ & $\begin{array}{l}\text { OBS: PARALELAMENTE, PASSA A } \\
\text { EXISTIR UMA SEGUNDA HIPÓTESE DE } \\
\text { DIVERGÊNCIA. }\end{array}$ \\
\hline $\begin{array}{l}\text { a) derem ao mesmo dispositivo de lei federal } \\
\text { interpretação diversa da que lhe houver dado } \\
\text { outro Tribunal Regional, no seu Pleno ou } \\
\text { Turma, ou a Seção de Dissídios Individuais do } \\
\text { Tribunal Superior do Trabalho, ou a Súmula } \\
\text { de Jurisprudência Uniforme dessa Corte } \\
\text { b) derem ao mesmo dispositivo de lei estadual, } \\
\text { Convenção Coletiva de Trabalho, Acordo } \\
\text { Coletivo, sentença normativa ou regulamento } \\
\text { empresarial de observância obrigatória em área } \\
\text { territorial que exceda a jurisdição do Tribunal } \\
\text { Regional prolator da decisão recorrida, } \\
\text { interpretação divergente, na forma da alínea a; }\end{array}$ & $\begin{array}{l}\text { Art. 896, "a", da CLT, na forma da redação dada } \\
\text { pela Lei no 9756/98. }\end{array}$ \\
\hline
\end{tabular}

Como se pode inferir ao observar as hipóteses legais de divergência, acima delineadas, no início da Justiça do Trabalho, exigia-se que o dissenso interpretativo fosse oriundo de outro Conselho ou do Conselho Nacional; pouco depois, exigiu-se que fosse de outro Conselho.

Esse dilema legal processual, no fundo, uma escolha política, ora limitando, ora ampliando o cabimento do recurso, ou seja, nalguns momentos históricos só permitindo-se a invocação de dissenso do mesmo Conselho/Regional e, noutras ocasiões, exigindo-se que a divergência invocável fosse de outro Conselho, envolve a solução de um problema que, até hoje, repita-se, parece não ter sido bem equacionado nos Tribunais Regionais, ou seja, a uniformização interna da própria jurisprudência, para o que urge dar um basta. 
Como se vê no Quadro I, a Lei 2244/54 permitiu que a divergência fosse do mesmo ou de outro Tribunal, o que subsistiu até o advento da Lei 9756/98, esta que restringiu à invocação de dissenso que só fosse oriundo de outro Tribunal, sistemática que vigora até a presente época (a. D. 2010).

De fato, cada Corte Regional haverá de fazer a unificação de sua jurisprudência interna, tal como veio a ser exigido pelo art. 14 da Lei $n^{\circ} 7701 / 88$; não é incumbência do Tribunal Superior do Trabalho fazê-lo, quando menos pela sua enorme carga de trabalho na pacificação das múltiplas questões de âmbito nacional.

Tendo em vista a possibilidade de ser criado mais de um Tribunal Regional do Trabalho dentro do mesmo Estado da Federação (art.113 da CF), fenômeno que existe, desde 1986, só no Estado de São Paulo, ou seja, a Segunda Região (com sede na capital e jurisdição em 46 Municípios) e a Décima Quinta Região (com sede em Campinas e jurisdição em 599 Municípios) ${ }^{202}$, tem maior importância a segunda hipótese de divergência jurisprudencial criada pela Lei no 7701/08 (letra "b"), pois, a partir dela, a letra "a" destina-se só para dissenso interpretativo de lei federal (g.n.). Até então, falou-se em interpretação diversa de lei, de norma jurídica e, depois, desde a Lei no 2244/54 até a superveniência dessa Lei no 7701/88, aludia-se, simplesmente, a dispositivo legal.

A letra "b", de outro lado, portanto, permite que o dispositivo legal questionado seja estadual, ou se trate de convenção, acordo, sentença normativa ou regulamento empresarial de observância em área territorial que exceda a jurisdição do Tribunal Regional prolator da decisão divergente, mas, sempre, desde que a discussão não estivesse já sedimentada pelo próprio TST, por súmula ou jurisprudência uniforme.

No Tribunal Superior do Trabalho, o recurso de Embargos, previsto no art. 894 da CLT, cumpre essa função unificadora da jurisprudência interna, desde sua inclusão pela Lei $n^{\circ}$ 2244/54 (para eliminar divergência de Turma, que ainda não houvesse sido dirimida pelo Pleno).

Este recurso foi ampliado pelo Decreto-lei no 229/67, permitindo-se o seu manejo caso fosse demonstrada violação à letra da lei federal (o que repetia a própria idéia do

\footnotetext{
${ }^{202}$ TRIBUNAL SUPERIOR DO TRABALHO. Municípios jurisdicionados. Disponível em: <http://www.tst.jus.br/tst/iframe.php?url=http://www.tst.jus.br/Sseest/VT/Munic2005.htm>. Acesso em: 08 set. 2010.
} 
recurso de revista), assim como no caso de divergência entre Turmas e entre estas e o Pleno, desde que a matéria não tivesse sido em consonância com Prejulgado ou com jurisprudência do próprio Tribunal.

A Lei $n^{\circ}$ 5442/68 manteve essa diretriz (violação e dissenso), aludindo, porém, à jurisprudência uniforme do Tribunal Superior do Trabalho, pois, se a decisão recorrida com ela estivesse de acordo, impediria o apelo.

Já pela Lei no 7033/82, uma vez extirpados os Prejulgados do cenário processual trabalhista, ${ }^{203}$ foram eles substituídos pela súmula de jurisprudência.

Só mais recentemente, retoma-se o primitivo curso no sentido de que os Embargos do art. 894 da CLT destinam-se à unificação da jurisprudência interna do TST: ele caberá “das decisões das Turmas que divergirem entre si, ou das decisões proferidas pela Seção de Dissídios Individuais, salvo se a decisão recorrida estiver em consonância com súmula ou orientação jurisprudencial do Tribunal Superior do Trabalho o do Supremo Tribunal Federal" (na exata dicção da Lei nº11.496/2007).

Veja-se, agora, no segundo quadro, a evolução da hipótese de cabimento do recurso de revista por violação de lei:

QUADRO II $^{204}$

\begin{tabular}{|l|l|l|}
\hline $\begin{array}{l}\text { b)proferidas com violação expressa de } \\
\text { direito. }\end{array}$ & $\begin{array}{l}\text { Art. 896, "b" do Decreto-lei no 5452/43, que } \\
\text { aprovou a CLT. } \\
\text { (ainda chamado recurso extraordinário) }\end{array}$ \\
\hline $\begin{array}{l}\text { b)proferidas com violação de norma } \\
\text { jurídica. }\end{array}$ & $\begin{array}{l}\text { Art. 896, "b" da CLT, com a redação dada } \\
\text { pelo Decreto-lei no 6353/44. } \\
\text { (ainda chamado recurso extraordinário) }\end{array}$ \\
\hline b)proferidas contra a letra expressa de lei. & $\begin{array}{l}\text { Art. 896, "b" da CLT, com a redação dada } \\
\text { pela Decreto-lei no 9737/46. } \\
\text { (ainda chamado recurso extraordinário) }\end{array}$ \\
\hline
\end{tabular}

${ }^{203}$ Vide, a propósito, julgamento da Representação de Inconstitucionalidade no 946/DF, Rel. Min. Xavier de Albuquerque, DJ. 01/07/1977, p. 4455, também encontrável no sítio do E. Supremo Tribunal Federal, SUPREMO TRIBUNAL FEDERAL. Disponível em: $<$ http://www.stf.jus.br/portal/jurisprudencia/listarJurisprudencia.asp?s1=CLT-

1943(946.NUME.\%20OU\%20946.ACMS.)(PLENO.SESS.)\&base=baseAcordaos>. Acesso em: 08 set. 2010.

${ }^{204}$ Quadro elaborado a partir das informações legislativas extraídas do sítio do Palácio do Planalto, BRASIL. Decreto-Lei n. 5.452, de $1^{\circ}$ de maio de 1943. Disponível em: <http://www.planalto.gov.br/ccivil_03/Decreto-Lei/Del5452.htm>. Acesso em: $1^{\circ}$ set. 2010. 


\begin{tabular}{|c|c|}
\hline $\begin{array}{l}\text { b)proferida com violação da norma } \\
\text { jurídica ou princípios gerais de direito. }\end{array}$ & $\begin{array}{l}\text { Art. } 896 \text {, "b" da CLT, com a redação dada } \\
\text { pela Lei n }{ }^{\circ} 861 / 49 \text {. } \\
\text { (doravante chamado recurso de revista) }\end{array}$ \\
\hline $\begin{array}{l}\text { b) proferidas com violacão de literal } \\
\text { disposicão da lei, ou de } \\
\text { normativa. }\end{array}$ & $\begin{array}{l}\text { Art. } 896, \text { "b" da CLT, com a redação dada } \\
\text { pela Lei n }{ }^{\circ} 2244 / 54 \text {. }\end{array}$ \\
\hline $\begin{array}{l}\text { II - Proferidas com violacão da norma } \\
\text { jurídica. }\end{array}$ & $\begin{array}{l}\text { Art. 896, II, da CLT, com a redação dada } \\
\text { pelo Decreto-lei no } 229 / 67 \text {. } \\
\text { (não se usaram letras para as hipóteses) }\end{array}$ \\
\hline $\begin{array}{l}\text { b) proferidas com violação de literal } \\
\text { disposição de lei ou de } \\
\text { normativa. }\end{array}$ & $\begin{array}{l}\text { Art. } 896, \text { "b", da CLT, com a redação dada } \\
\text { pela Lei n }{ }^{\circ} 5452 / 68\end{array}$ \\
\hline $\begin{array}{l}\text { c) proferidas com violação de literal } \\
\text { dispositivo de lei federal, ou da } \\
\text { Constituição da República. }\end{array}$ & $\begin{array}{l}\text { Art. 896, "c", da CLT, com a redação dada } \\
\text { pela Lei n } 7701 / 88 \text {. } \\
\text { N.B. A violação de lei passou a estar } \\
\text { prevista na letra "c" porque incluída nova } \\
\text { hipótese de divergência na letra "b", por } \\
\text { força dessa mesma lei } 7701 / 88 \text {. }\end{array}$ \\
\hline $\begin{array}{l}\text { c) proferidas com violação literal de } \\
\text { disposição de lei federal ou afronta direta e } \\
\text { literal à Constituição Federal. }\end{array}$ & $\begin{array}{l}\text { Art. 896, “c”, da CLT, com a redação dada } \\
\text { pela Lei no 9756/98. } \\
\text { SITUAÇÃO ATUAL, EM } 2010 .\end{array}$ \\
\hline
\end{tabular}

Já se aludiu, há pouco, o vai e vem da ampliação e retração do cabimento do recurso de revista por violação, hipótese de cabimento que só veio introduzida pelo Decreto-lei 5452/43 (CLT)

De início cogitou-se de violação expressa de direito; depois, sem qualquer qualificação da infringência, ampliou-se para violação de norma jurídica; em seguida, letra expressa de $1 \mathrm{ei}^{205}$.

Houve novo alargamento ao se incluírem princípios gerais de direito, até que, pela primeira vez, se qualificou a violação, exigindo-se que ela seja literal.

\footnotetext{
${ }^{205}$ RUSSOMANO, Mozart Victor. Comentários à Consolidação das Leis do Trabalho, cit., v. 5, p. 15721573, tece críticas a respeito dessa oscilação do legislador no tratamento da hipótese da letra "c", o mesmo tendo feito MALLET, Estêvão. Do recurso de revista no processo do trabalho, cit., p. 29.
} 
Nova generalização foi feita quando se cogitou de violação de norma jurídica (1967), tendo durado pouco, pois, já em 1968, retoma-se a violação literal de disposição de lei, acrescentando-se, porém, a sentença normativa.

Foi a Lei $n^{o}$ 7701/88 que fixou o tipo de violação e de norma jurídica: a primeira deve ser literal e a segunda só pode ser lei federal ou da Constituição da República.

A atual redação da letra "c", decorrente da Lei n 9756/98 veio a ser mais rígida com a infringência constitucional, pois exige que se trate de afronta direta e literal a preceito da Constituição Federal.

E, se compararmos com o recurso extraordinário constitucional (art.102,III, “a”, da CF) neste não se menciona, qualifica ou se restringe o tipo de violação, ou seja, a lei trabalhista está exigindo mais para um recurso inferior do que para o faz a própria Constituição, ainda mais agora, com a repercussão geral.

Antes de terminar estas linhas sobre a evolução histórica e legislativa do recurso de revista no Brasil, importante frisar que o art. 73 do Decreto 1237, de 02 de maio de 1939, o qual (reafirme-se) organizou a Justiça do Trabalho, já exigia que a decisão recorrida fosse definitiva e de última instância.

Esta singularidade prevaleceu, desde 1943, nas várias redações legais do art. 896 da CLT, até que a Lei 9456/98, que dá a atual, deixou mais explícito ainda: os julgamentos regionais que comportam recurso de revista para o TST haverão de ser aqueles proferidos “em grau de recurso ordinário em dissídio individual”.

De fato, esta melhor definição legal resulta do já antes firme entendimento segundo o qual não caberia revista contra julgamentos regionais de caráter interlocutório, salvo exceções estabelecidas em nome de prevalência da própria autoridade da Jurisprudência do TST, assim como em nome dos princípios da concentração, simplificação, necessidade e celeridade processuais. $^{206}$

\footnotetext{
${ }^{206}$ Desde sua primitiva redação, de 1985, nesse sentido é a Súmula 214/TST, verbis: "DECISÃO INTERLOCUTÓRIA. IRRECORRIBILIDADE (nova redação) - Res. 127/2005, DJ 14, 15 e 16.03.2005 Na Justiça do Trabalho, nos termos do art. $893, \S 1^{\circ}$, da CLT, as decisões interlocutórias não ensejam recurso imediato, salvo nas hipóteses de decisão: a) de Tribunal Regional do Trabalho contrária à Súmula ou Orientação Jurisprudencial do Tribunal Superior do Trabalho; b) suscetível de impugnação mediante recurso para o mesmo Tribunal; c) que acolhe exceção de incompetência territorial, com a remessa dos
} 
O mesmo raciocínio vale para as decisões regionais proferidas em agravo de instrumento, estes sabidamente restritos à decisão de inadmissibilidade dos recursos, por força da letra "b" do art. 897 da CLT, o que já vinha consagrado, também desde 1985, pela Súmula 218/TST. ${ }^{207}$

Há de se referir a outra notável oscilação legislativa na questão da recorribilidade extraordinária das decisões proferidas em execução do título judicial, situação já antes mencionada no processo de conhecimento e, em boa medida, dependente e coincidente com os períodos políticos de exceção e de abertura democrática.

Assim, desde os primórdios, era aceita a vedação da revista, tout court, por força da introdução do $\S 4^{\circ}$ do art. 896 da CLT ${ }^{208}$, ocorrido com a da Lei 2244/54.

Tal vigorou até o advento do Decreto-lei no 229/67, cujo art. 28 alterou referido $\S 4^{\circ}$ do art. 896 da CLT, autorizando "recurso", em cinco dias, para o Corregedor da Justiça do Trabalho.

Essa equívoca redação criava recurso inominado, com prazo diferenciado e (hoje se vê) misturando a atividade administrativa do Corregedor com a atividade jurisdicional típica, na qual, salvo excepcional e gravíssima situação, não há lugar para atuação correicional, esta limitada às hipóteses de errores in procedendo, para os quais não haja recurso, e de tumultos processuais, o que, hoje em dia, está englobado na fórmula "atos atentatórios à boa ordem processual", conforme previsão do art. 5, II, do Regimento Interno da Corregedoria-Geral da Justiça do Trabalho ${ }^{209}$.

autos para Tribunal Regional distinto daquele a que se vincula o juízo excepcionado, consoante o disposto no art. $799, \S 2^{\circ}$, da CLT." Texto de acordo com o sítio do TRIBUNAL SUPERIOR DO TRABALHO. Súmulas da Jurisprudência Uniforme do Tribunal Superior do Trabalho. Disponível em: <http://www.tst.jus.br/jurisprudencia/Livro_Jurisprud/livro_html_atual.html\#Sumulas >. Acesso em: 08 set. 2010.

${ }^{207}$ RECURSO DE REVISTA. ACÓRDÃO PROFERIDO EM AGRAVO DE INSTRUMENTO (mantida) -

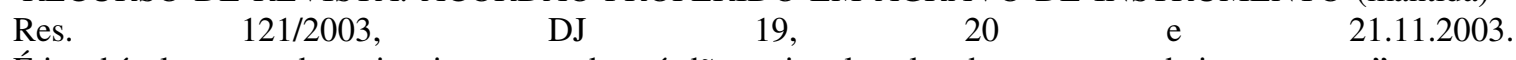
É incabível recurso de revista interposto de acórdão regional prolatado em agravo de instrumento.”

Texto de acordo com o sítio do TRIBUNAL SUPERIOR DO TRABALHO. Súmulas da Jurisprudência Uniforme do Tribunal Superior do Trabalho. Disponível em: $<$ http://www.tst.jus.br/jurisprudencia/Livro_Jurisprud/livro_html_atual.html\#Sumulas>. Acesso em: 08 set. 2010.

${ }^{208}$ De acordo com a evolução legislativa do art. 896 da CLT, encontrável no sítio do Palácio do Planalto, BRASIL. Decreto-Lei n. 5.452, de $1^{\circ}$ de maio de 1943. Disponível em: <http://www.planalto.gov.br/ccivil_03/Decreto-Lei/Del5452.htm>. Acesso em: $1^{\circ}$ set. 2010.

${ }^{209}$ Regimento da Corregedoria-Geral, acessível no sítio do TRIBUNAL SUPERIOR DO TRABALHO. Disponível em: <http://www.tst.jus.br/iframe.php?url=http://www.tst.jus.br/jurisprudencia/brs/bdcg.html>. Acesso em: 08 set. 2010. 
Não tardou muito, a Lei 5442/68, deu nova redação ao $\S 4^{\circ}$ do art. 896 da CLT, voltando à proibição total do recurso de revista na execução.

Essa vedação indiscriminada, à luz do art. 143 da Constituição de 1967, e, afinal, de toda a doutrina constitucional, mais elementar, confrontava-se com principio magno que garante acesso ao Supremo Tribunal Federal, órgão máximo do Poder Judiciário, exatamente incumbido de resguardar e fazer cumprir a Constituição Federal. Por isso que, julgando o Recurso Extraordinário $\mathrm{n}^{\circ}$ 89.145-PA, Relator o Ministro Xavier de Albuquerque, DJU 09/03/1979, o Plenário do Supremo Tribunal assentou que lei ordinária, como no caso o $\S 4^{\circ}$ do art. 896 da CLT, não poderia ser interpretada a ponto de impedir que o contencioso constitucional fosse sonegado à Suprema Corte, daí que ela interpretou essa norma determinando que o Tribunal Superior do Trabalho julgasse o recurso de revista sob a ótica do tema constitucional. ${ }^{210}$

Essa jurisprudência do Supremo Tribunal Federal fez com que a viabilização da revista em execução ocorresse da maneira como restou cristalizado, em 1987, com a primeira redação da Súmula 266/TST, que exigia demonstração inequívoca de violência direta à Constituição Federal, o que, presentemente, se mantém ${ }^{211}$ e está confirmado no $\S$ $2^{\circ}$ do art. 896 da CLT, com a redação que lhe deu a Lei 9756/98. Exige, porém, a lei atual "ofensa direta e literal à Constituição Federal".

Esta solução mereceu acerba crítica de Antônio Álvares da Silva para quem não seria imprescindível essa prévia discussão constitucional pelo TST, na medida em que, pela Lex Máxima, ao Supremo está confiada a análise do tema constitucional, de sorte que

\footnotetext{
${ }^{210}$ MALLET, Estêvão. Do recurso de revista no processo do trabalho, cit., p. 31, na nota de rodapé $\mathrm{n}^{\mathrm{o}} 66$. Inteiro teor do julgamento deste Recurso Extraordinário no sítio do Supremo Tribunal Federal. SUPREMO TRIBUNAL FEDERAL. Disponível em: $<$ http://redir.stf.jus.br/paginador/paginador.jsp?docTP=AC\&docID=182904>. Acesso em: 13 set. 2010.

${ }^{211}$ SUM- 266 RECURSO DE REVISTA. ADMISSIBILIDADE. EXECUÇÃO DE SENTENÇA (mantida) Res. 121/2003, DJ 19, 20 e 21.11.2003. A admissibilidade do recurso de revista interposto de acórdão proferido em agravo de petição, na liquidação de sentença ou em processo incidente na execução, inclusive os embargos de terceiro, depende de demonstração inequívoca de violência direta à Constituição Federal. TRIBUNAL SUPERIOR DO TRABALHO. Súmulas da Jurisprudência Uniforme do Tribunal Superior do Trabalho. Disponível em: $<$ http://www.tst.jus.br/jurisprudencia/Livro_Jurisprud/livro_html_atual.html\#Sumulas $>$. Acesso em: 08 set. 2010. Acesso em 13 set. 2010. Não se podem ignorar a respeito do sentido e alcance da violação constitucional, autorizadora do recurso de revista em execução, o que sinalizam a Súmula 401, a OJ-TP-6, a OJ-SDI-1 262 e as OJs. SDI-2 35, 123 e 262 do Tribunal Superior do Trabalho, acessíveis no mesmo sítio, agora referido.
} 
visou-se "unicamente a evitar sobrecarga ao STF. Foi, portanto, uma mera razão de conveniência". ${ }^{212}$

O que acima foi esclarecido sobre a impossibilidade de lei ordinária interceptar o contencioso constitucional já havia sido observado no $\S 4^{\circ}$ do art. $2^{\circ}$ da a Lei 5584/70, que obstava qualquer recurso nos chamados processos de alçada (até dois salários mínimos), salvo se versarem matéria constitucional, o que, todavia, ainda gera controvérsias, tal como demonstra José Janguiê Bezerra Diniz. ${ }^{213}$

Mais recentemente, é possível invocar similitude com o modelo recursal perante os Juizados Especiais (Leis 9099/95 e 10.259/01), cujas decisões, se recorridas, passam primeiramente por um colegiado, a Turma Recursal, e, só depois, podem subir ao STF, via extraordinário, verificando-se se é o caso de processos repetitivos, só sendo encaminhados alguns desses exemplificativos da controvérsia constitucional, conforme explana Gilmar Ferreira Mendes. $^{214}$

Aquela precaução de não impedir a análise do contencioso constitucional foi observada quando introduzido o procedimento sumaríssimo pela Lei 9957/00 (arts. 852-A usque 852-I), pois nesse caso a admissão do recurso de revista foi restringida às hipóteses de contrariedade a súmula e a violação direta da Constituição da República, consoante o $§$ $6^{\circ}$ do art. 896 da CLT, antes, porém, passando pelo TST, sistemática diferente do que ocorre com o STJ.

Em síntese, a construção do recurso de revista ao longo da experiência legislativa brasileira e, inegavelmente, com os influxos da construção jurisprudencial do Tribunal Superior do Trabalho, resultou que, hoje em dia, ele é exercitável contra decisões definitivas de Tribunal Regional do Trabalho, proferidas em julgamento de recurso ordinário em dissídio individual (singular ou plúrimo), na fase cognitiva de procedimento ordinário, quando for demonstrada atual divergência jurisprudencial de outro Tribunal Regional do Trabalho ou do TST, por intermédio da Seção de Dissídios Individuais.

\footnotetext{
${ }^{212}$ SILVA, Antônio Álvares. op. cit., p. 121. Este mesmo Professor Titular da UFMG, à p. 122, sugere que o recurso extraordinário para o STF haveria de ser proposto perante os TRTs e, se trancados, seria definitiva a execução, mesmo com a interposição de agravo de instrumento.

${ }^{213}$ DINIZ, José Janguiê Bezzera. Recursos no processo do trabalho. São Paulo: LTr. 2005. p. $42-43$.

${ }^{214}$ MENDES, Gilmar Ferreira; COELHO, Inocêncio Mártires; BRANCO, Paulo Gustavo Gonet. op. cit., p. 965-966.
} 
Cabe aqui colocar em especial relevo uma tríplice forma de manifestação e de identificação da jurisprudência do TST, que viabilizará ou, não, o trânsito da revista: a primeira, evidente, é quando houver contrariedade a Súmula do TST, na interpretação de lei federal (letra “a”). As Súmulas podem ser fundidas, nelas reunindo outras antigas, como é o caso da atual Súmula 06/TST, inclusive associando-se a OJs. ${ }^{215}$

A segunda, também perceptível e clara, diz respeito às questões objeto das várias Orientações Jurisprudenciais, que representam a iterativa, notória e atual jurisprudência da Corte, na definição da Súmula 333/TST. Pode-se dizer que a "OJ" constitui um estado embrionário de futura súmula, como, por exemplo, ocorreu com a Súmula 388/TST, fruto de conversão das antigas OJs 201 e 314 e com a Súmula 395/TST. ${ }^{216}$ Noutras vezes, elas dizem respeito a questões regionais, restritas a determinadas empresas ou situações estaduais ou, também, estão em fase de teste para sobrevivência, aglutinação ou fusão a verbetes já existentes, tal como ocorre com as chamadas OJs Transitórias, ou se deu com a famosa OJ 320, afinal revogada, ou com as OJs 328 e 298, hoje itens da Súmula 06/TST. ${ }^{217}$

A terceira forma é mais sutil: é fruto daquela típica, constante e silenciosa construção jurisprudencial da Seção de Dissídios Individuais (I e II) em torno de determinadas matérias, necessitando ser pesquisada junto ao próprio Tribunal Superior do Trabalho, o qual, inclusive, no seu sítio da internet já identifica "matérias temáticas".

Tempos atrás havia no sítio público do TST os temas ainda não convertidos em orientação jurisprudencial, o que, atualmente, não se sabe por que, só estão disponíveis na “intranet", ou seja, internamente. ${ }^{218}$

Também se viabiliza esse recurso na hipótese de interpretação divergente (letra "b") em torno de lei estadual, convenção ou acordo coletivos, sentença normativa ou

\footnotetext{
${ }^{215}$ TRIBUNAL SUPERIOR DO TRABALHO. Súmulas da Jurisprudência Uniforme do Tribunal Superior do Trabalho. Disponível em: $<$ http://www.tst.jus.br/jurisprudencia/Livro_Jurisprud/livro_html_atual.html\#Sumulas>. Acesso em: 08 set. 2010, aonde se encontram todas as Súmulas do Tribunal Superior do Trabalho e as Orientações Jurisprudenciais, devidamente atualizadas e com a indicação da respectiva gênese.

${ }^{216}$ Id. Ibid.

${ }^{217} \mathrm{Na}$ forma da nota de rodapé anterior.

${ }^{218}$ Acessível no sítio principal do TST: <http://www.tst.jus.br> quanto às matérias temáticas; quanto aos temas não convertidos em orientação jurisprudencial, presentemente, está vedado ao público externo, embora, antes, localizado em TRIBUNAL SUPERIOR DO TRABALHO. Temas não Convertidos em Orientação Jurisprudencial. Disponível em: <http://www.tst.gov.br/jurisprudencia/n_temas_nao_convertidos_oj.html>. Acesso em: 08 set. 2010.
} 
norma empresarial que exceda a competência do Tribunal Regional prolator do acórdão recorrido, nas mesmas condições da letra "a".

Caberá, ainda a revista na hipótese de demonstração de violação literal de lei federal ou afronta direta e literal à Constituição Federal.

No procedimento sumaríssimo, a admissibilidade da revista restringe-se à contrariedade a Súmula do TST e violação direta (g.n.)da Constituição Federal.

Finalmente, em execução de sentença, só será admissível o recurso de revista quando demonstrada violação direta e literal (g.n.) de norma da Constituição Federal. ${ }^{219}$

\footnotetext{
${ }^{219}$ Não se ignorem críticas doutrinárias à dimensão, que, afinal, tomou o recurso de revista, dentre elas a de TOLEDO FILHO, Manoel Carlos. Fundamentos e perspectivas do processo trabalhista brasileiro. São Paulo: LTr, 2006. p. 148-150. Segundo este Autor, a revista deveria restringir-se à hipótese de violação de lei ou da Constituição, excluída a divergência jurisprudencial. Esta última deveria ser repensada, o que vai de encontro à tese unitária do ordenamento jurídico; o juiz não é só intérprete da norma, mas seu criador, pois o direito passa a existir no julgamento, dele dependendo sua própria existência., por isso a necessidade da uniformização das decisões para a preservação da ordem jurídica.
} 


\section{CAPÍTULO II. O SURGIMENTO DA TRANSCENDÊNCIA NO RECURSO DE REVISTA}

\subsection{O Projeto de Lei 3267/2000 (tramitação e arquivamento)}

Em 19 de junho de 2000, invocando o $\S 1^{\text {o }}$ do art. 64 da Constituição Federal, que prevê a possibilidade de o Chefe do Executivo "solicitar urgência para a apreciação de projetos de lei de sua iniciativa," o Presidente da República Federativa do Brasil, Fernando Henrique Cardoso, pela Mensagem no 831 (fl.9) ${ }^{220}$, encaminhou para deliberação dos Membros do Congresso Nacional Projeto de Lei, que tomou o n ${ }^{\circ} 3267 / 2000$, acompanhado de Exposição de Motivos elaborada pelos Ministros de Estado do Trabalho e Emprego, interino, e da Justiça, proposição esta que “Acrescenta dispositivos à Consolidação das Leis do Trabalho, dispondo sobre requisitos de admissibilidade para o recurso de revista". 221

A proposta legislativa está vazada nos seguintes termos:

\section{O CONGRESSO NACIONAL, decreta:}

Art. $1^{\circ}$ Acrescenta-se ao Decreto-Lei 5.452, de $1^{o}$ de maio de 1943, Consolidação das Leis do Trabalho - CLT, o seguinte art. 896-A:

Art. 896-A. O Tribunal Superior do Trabalho não conhecerá de recurso oposto contra decisão em que a matéria de fundo não ofereça transcendência com relação aos reflexos gerais de natureza jurídica, política, social e econômica.

$\S 1^{\circ}$ Considera-se transcendência:

I - jurídica, o desrespeito patente aos direitos humanos fundamentais ou aos interesses coletivos indisponíveis, com comprometimento da segurança e estabilidade das relações jurídicas;

\footnotetext{
${ }^{220}$ Em uma das viagens a Brasília, no Centro de Documentação e Informação (CEDI) da Câmara dos Deputados, obteve-se xerocópia do Projeto de Lei 3267 de 2000, ou seja, do "processo legislativo," em si, que tramitou naquela Casa Legislativa, daí o porquê da indicação concreta do número das folhas que compõem o Projeto de Lei.

${ }^{221}$ A íntegra do Projeto de Lei 3267/2000 pode ser acessada no sítio da Câmara dos Deputados, Brasília, DF. CÂMARA DOS DEPUTADOS. Projeto de Lei e Outras Proposições. PL-3267/2000. Disponível em: $<$ http://www.camara.gov.br/sileg/Prop_Detalhe.asp?id=19377>. Acesso em: 23 set. 2010. Ele se encontra arquivado, por decisão da Mesa Diretora da Câmara, em razão de solicitação de sua retirada por parte do Poder Executivo.
} 
II - política, o desrespeito notório ao princípio federativo ou à harmonia dos Poderes constituídos;

III - social, a existência de situação extraordinária de discriminação, de comprometimento do mercado de trabalho ou perturbação notável à harmonia entre capital e trabalho;

IV - econômica, a ressonância de vulto da causa em relação a entidade de direito público ou economia mista, ou a grave repercussão da questão na política econômica nacional, no segmento produtivo ou no desenvolvimento regular da atividade empresarial.

$\S 2^{\circ}$ O Tribunal, ao apreciar o recurso oposto contra decisão que contrarie a sua jurisprudência relativa à questão transcendente, salvo o caso de intempestividade, dará prazo para que a parte contrária supra o não-preenchimento de pressuposto extrínseco do recurso.

$\S 3^{\circ}$ O Tribunal não conhecerá de recurso fundado em aspecto processual da causa, salvo com apoio em disposição constitucional direta e literalmente violada, quando o tema de fundo estiver pacificado em sua jurisprudência no sentido da decisão proferida pelo tribunal inferior.

Art. $2^{\circ}$ O Tribunal Superior do Trabalho regulamentará, no prazo de sessenta dias da publicação desta Lei, o procedimento de seleção dos recursos transcendentes e de uniformização na aplicação dos critérios de transcendência.

Art. $3^{\circ}$ Esta Lei entrará em vigor sessenta dias após a data de sua publicação.

Brasília, ”

O inteiro teor da proposta do art. 896-A, acima transcrito (fl.1), se fez acompanhar de xerocópia do art. $64, \S \S 1^{\circ}, 2^{\circ}, 3^{\circ}$ e $4^{\circ}$ da Constituição Federal, que faz parte do Título IV, da Organização dos Poderes, Capítulo I, do Poder Legislativo, Seção VIII, Do Poder Legislativo, subseção III, Das Leis (fls. 2/3).

Também acompanhava o projeto xerocópia de parte do preâmbulo da Emenda Constitucional $\mathrm{n}^{\mathrm{o}}$ 1, de 17 de outubro de 1969 e do preceito que, no âmbito do Título I, Da Organização Nacional, Capítulo VIII, Do Poder Judiciário, Seção II - Do Supremo Tribunal Federal, qual seja, o art. 119, I, “a”, II, “a”, "b”, “c”, e III, “a”, “b”, “c”, “d” e $\S$ $1^{\circ}$, este último que, pela significação para este estudo, diz o seguinte: "As causas a que se refere o item III, alíneas a e d, deste artigo serão indicadas pelo Supremo Tribunal Federal no regimento interno, que atenderá à sua natureza, espécie, valor pecuniário e relevância da questão federal" (fls. 4/5, g.n.). 
Seguiam-se cópias dos arts. 896 e 897 da CLT, nas suas últimas redações, vigentes no ano de 2000 (fls.6/8).

Chega-se, então, à Exposição de Motivos no 31, datada de 09 de junho de 2000, como se disse, assinada por Paulo Jobim Filho, Ministro de Estado do Trabalho e Emprego, interino, e por José Gregori, Ministro de Estado da Justiça.

E, faça-se aqui, brevíssimo parêntesis para fazer um destaque ou constatação: é nítida a influência que Ministros do Trabalho, ainda atualmente, têm tido no encaminhamento de leis disciplinando temas que não são trabalhistas típicos, mas, como no caso, que, exclusivamente, dizem respeito ao processo do trabalho e à competência do Tribunal Superior do Trabalho, situação que remete aos primórdios da criação da própria Justiça do Trabalho, ainda na década de 30, quando fora da estrutura do Poder Judiciário, daí, talvez, a marcante influência do Poder Executivo, o que, agora, causa espécie. Ou, talvez, porque mexer na CLT é um ponto crítico de todos os Governos.

De volta à exposição de motivos, revela-se de suma importância transcrevê-la, na medida em que se vêem as justificativas (de lege ferenda) para a implantação do critério da transcendência e, posteriormente, reiteradas por ocasião da edição da Medida Provisória 2226/2001, cuja exposição de motivos merecerá confronto específico e oportuno com a deste Projeto de Lei. Vejam-se, pois, os respectivos termos:

\section{Excelentíssimo Senhor Presidente da República}

Técnica a ser adotada para o desafogamento dos Tribunais Superiores, simplificação dos recursos e caracterização dessas Cortes como instâncias extraordinárias é a da demonstração da relevância federal ou transcendência política, social, econômica ou jurídica das causas que merecerão a apreciação dos Tribunais Superiores.

A inserção dessa espécie de requisito para a admissibilidade dos recursos de natureza extraordinária é de suma importância para não vulgarizar os tribunais superiores. Se todos os processos acabarem desembocando nas Cortes Superiores, o que era extraordinário passa a ser ordinário, com a desenganada intenção das partes de rediscutir indefinidamente as questões nas quais litigam.

A Suprema Corte americana adota tal técnica, ao escolher os processos que irá julgar, conforme sua relevância. Uma vez decidida a questão, com a formação do precedente, a jurisprudência formada passa a ser aplicada pelos juízes e cortes inferiores, podendo ser revista apenas se a Suprema Corte considerar que surgiram novos argumentos que justifiquem uma revisão de sua decisão originária. 
Sob o império da Carta Política de 1967/1969, o Supremo Tribunal Federal, como instância uniformizadora da jurisprudência em torno da interpretação da Constituição e da lei federal, funcionou com técnica semelhante, consistente na arguição de relevância da questão federal, que deveria ser demonstrada no recurso extraordinário, para que pudesse transitar pelo STF (CF 67/69, art. 119,III e $\$ 1^{\circ}$ ).

O insucesso do sistema da arguição de relevância no Supremo Tribunal Federal deveu-se á necessidade do STF justificar motivadamente a não apreciação meritória de todos os processos que deixassem de ser julgados. Assim, não havia efetiva diminuição de processos, continuando o STF com a sobrecarga inviabilizadora de uma apreciação mais acurada dos processos que efetivamente fossem julgados, pela sua relevância.

Assim, a melhor técnica a ser adotada é, efetivamente, aquela vivenciada pela Suprema Corte americana, que atua com discricionaridade na seleção das causas que vai julgar, em face da repercussão geral que teriam na sociedade e na economia, sem necessidade de justificar o motivo pelo qual não apreciará as demais causas.

Caberia, nesse contexto, à parte demonstrar a transcendência política, social, econômica ou jurídica da causa, fundamentadamente, para que os Tribunais Superiores as examinem.

O presente projeto elenca, em seu $\$ 1^{\circ}$ os critérios de transcendência, que justificarão uma atuação das Cortes Superiores.

Como em nosso sistema jurídico o duplo grau de jurisdição já assegura às partes a revisão, por um colegiado, da decisão proferida pelo juiz singular, obtendo-se rejulgamento integral da causa, com rechace de fatos e provas e do direito aplicável à hipótese, conclui-se que os tribunais superiores não têm a missão de fazer justiça, no sentido de reexaminar a causa, mas de garantir a aplicação uniforme do direito federal em todo o território nacional. Assim, sua missão transcende o interesse das partes, ligando-se à defesa dos interesses do Estado Federado, de que suas normas não sejam desobervadas por alguma das unidades que compõem a Federação.

Daí que apenas as questões que transcendem o interesse das partes, para afetar o próprio interesse da sociedade organizada em Estado Federal, é que merecerão ser julgadas pelas Cortes Superiores. E caberá a essas Cortes, com seu poder discricionário, aquilatar se a questão concreta se revela transcendente. Do contrário, continuarão os tribunais superiores a funcionar como $3^{a}$ ou $4^{a}$ instância ordinária, julgando de forma sumária os processos que lhes chegam, em sistema que apresenta maior discricionaridade do que o que se adotaria explicitamente.

Com a adoção do critério da transcendência das questões federais, poderão os tribunais superiores ter condições de apreciar com tranquilidade, segurança, consciência e precisão as causas que lhes forem dirigidas, dedicando seu tempo àquelas que, efetivamente, terão repercussão tal na comunidade, que exigem detida análise de todos os aspectos que a envolvam, de modo a que a solução seja a que melhor atenda aos interesses da sociedade. 
Os $\S \S 2^{\circ}$ e $3^{\circ}$ se justificam tendo em vista que, em relação às questões transcendentes, mormente que envolvam impacto de vulto no patrimônio público, muitas vezes não convenientemente defendido, em face das notórias deficiências da advocacia de Estado, a falha processual é buscada como tábua de salvação para se obter vantagem de direito material, reconhecidamente contrária ao ordenamento jurídico.

Tal é o caso das ações relativas a planos econômicos, cujas diferenças inflacionárias não foram reconhecidas pelo STF, e que, principalmente em relação a empresas estatais, só as receberam os empregados que contaram com o tropeço dos patronos empresariais em percalços processuais, pois a questão de fundo já se encontrava pacificada. Daí o quadro de inaceitável discriminação entre empregados que receberam as referidas diferenças, quando a massa dos trabalhadores não fizeram (sic) jus a elas, apenas por falhas processuais.

Respeitosamente,"

Afinal, o Projeto de Lei veio a ser encaminhado ao Primeiro Secretário da Câmara dos Deputados, Deputado Ubiratan Aguiar, pelo aviso n ${ }^{\circ} 1010$ da Casa Civil, assinado por Pedro Parente, Chefe da Casa Civil da Presidência da República, em 19 de junho de 2000 (fl. 13), com carimbo de recebimento do dia subsequente, 20 de junho de 2000, pela Primeira Secretaria da Câmara.

As singularidades envolvendo a gênese legislativa da transcendência do recurso de revista, por certo, exigiram que se fizesse pesquisa in loco, isto é, junto à Câmara dos Deputados, mormente porque, como se verá em seguida, esse Projeto de Lei do Poder Executivo, afinal, por ele foi "retirado", mas, pouquíssimo tempo depois, a mesma transcendência ressurgiu ou foi reproposta no bojo da Medida Provisória nº 2226/2001.

A análise e comparação dessas iniciativas legislativas é imprescindível para os propósitos deste estudo porque, indiscutivelmente, têm elas origem no próprio Poder Executivo (Casa Civil da Presidência da República) e, na Medida Provisória, a Exposição de Motivos é delineadora dos pressupostos da própria urgência e relevância, previstas no art. 62 da Constituição Federal.

Como se viu logo no início deste capitulo, a mensagem presidencial que encaminhou o projeto de lei, visando a criar o art. 896-A da CLT, invocou o $\S 1^{\circ}$ do art. 64 da Constituição Federal, vale dizer, solicitou urgência na tramitação. 
Assim, logo no dia 21 de junho de 2000, a Mesa Diretora da Câmara dos Deputados determinou o apensamento deste projeto do Executivo a um outro anterior, PL no 168/99, de iniciativa do Deputado Jacques Vagner, portanto do Poder Legislativo, matéria conexa, cujo teor e justificativa podem ser compulsados no já antes referido sítio da Câmara dos Deputados ${ }^{222}$, sendo certo, também, que foi publicado no Diário da Câmara dos Deputados do dia 04 de março de 1999, quinta-feira, às páginas 07700 usque 07703.

Este anterior Projeto de Lei do Legislativo buscava dar novo tratamento ao art. 896 da CLT, que alvitra as hipóteses de cabimento do recurso de revista. Sua declarada intenção era ver concretizados nas "fases recursais dos processos trabalhistas, os salutares princípios de proteção, da celeridade, da oralidade, da concentração e da simplificação dos atos processuais, com todas as óbvias vantagens decorrentes".

Assim, a primeira idéia dessa proposta do (à época) Deputado Jacques Wagner era simplificar a forma dos julgamentos no caso de manutenção da decisão recorrida, para tanto sendo bastante a lavratura de certidão, sem necessidade de acórdão, com breve indicação dos fundamentos, o que, tempos depois, veio a se concretizar, em parte, no caso do julgamento dos processos submetidos ao procedimento sumaríssimo, tal como se vê dos arts. 852-I e 893, $\S 1^{\circ}$, incisos IV, ambos da CLT e acrescentados pela Lei 9957, de 12 de janeiro de 2000 .

A segunda perspectiva desse projeto era impor multa variável entre $10 \%$ e $40 \%$ por litigância de má-fé, específica, na fase recursal, caso viesse a ser confirmada a decisão recorrida, por seus próprios fundamentos.

\section{A terceira proposta residia na ampliação dos dissídios de alçada, que} passariam a cinco vezes o salário mínimo, impedindo-se quaisquer recursos, salvo se a lide versasse "sobre matéria constitucional ou sobre punições disciplinares diversas do despedimento".

A quarta, dirigia-se à vedação de recursos ordinários em dissídios coletivos, só “cabíveis quando ocorrer violação de literal dispositivos de lei federal, ou da Constituição

\footnotetext{
${ }^{222}$ CÂMARA DOS DEPUTADOS. Projeto de Lei e Outras Proposições. PL-168/1999. Disponível em: $<$ http://www.camara.gov.br/sileg/Prop_Detalhe.asp?id=15118>. Acesso em: 23 set. 2010. Este projeto de lei, do então Deputado Jacques Wagner, foi arquivado em 17 de abril de 2001 pela Mesa Diretora da Câmara dos Deputados, que deferiu seu pedido de retirada.
} 
da República ( $§ 4^{\circ}$ do art. 895), ou seja, nas mesmas hipóteses de cabimento do recurso de revista interponível nos dissídios individuais".

Por derradeiro, no que se refere ao recurso de revista, a proposta do PL n ${ }^{\circ}$ 168/1999 era bem radical: ficaria eliminada a hipótese de divergência jurisprudencial para o cabimento desse recurso, o que esvaziaria a primordial razão de existência do Tribunal Superior do Trabalho, que, diferentemente do STJ (art. 105 da CF) e do TSE (art. 121 da $\mathrm{CF}$ ), tem sua competência disciplinada pela legislação ordinária, depois de estabelecidas as linhas mestras pelo art. 114 da Carta Política.

O drástico corte proposto exige contato direito com a justificativa apresentada, pois o recurso de revista restringir-se-ia

para as hipóteses de "violação de literal dispositivo de lei federal ou da Constituição da República” (art. 886). Isto por dois motivos principais:

a) Numa República que se proclama federativa e possui território de dimensões continentais, onde coexistem condições

socioeconômicas e culturais sobremodo díspares, senão

contraditórias, é de todo descabida e injustificada, não se explicando a não ser como persistente sequela de antidemocráticos períodos de centralização e autoritarismo, qualquer preocupação com a uniformização da jurisprudência, ao nível nacional. Em sã consciência e com o espírito desarmado de sectatismos, não se pode realmente pretender que a lei, que já é uma só para todo o País, seja interpretada e aplicada de modo idêntico, por juízes do Norte, do Nordeste, do CentroOeste, do Sudeste e do Sul, que vivenciam realidades sociais, econômicas e culturais sobremodo diversas, caracterizadoras de estágios evolutivos classificáveis como primeiromundistas, em fase de desenvolvimento e subdesenvolvidos,

em graus variados.

b) Além disso, constitui fato notório, para os profissionais da área trabalhista do Direito, que o recurso de revista por divergência jurisprudencial tem sido usado, na prática, marcadamente mais como condenável expediente protelatório de encerramento dos processos, vale dizer, como sério obstáculo à celeridade processual, do que como instrumento de uniformização jurisprudencial.

E tal deturpação resulta ainda mais óbvia e preocupante, quando se tem em conta o vultoso número de recursos de revista que deixam de ser encaminhados ao Tribunal Superior do Trabalho, por não haverem logrado ultrapassar o juízo de admissibilidade que a lei confere aos Presidentes do Tribunais Regionais. 
É que, ao contrário do que pode parecer à primeira vista, a interposição desses recursos incabiveis gera enorme perda de tempo, decorrente não só do estudo necessário à fundamentação dos despachos relativos à respectiva admissibilidade, como também do processamento e posterior julgamento pelo Tribunal Superior do Trabalho, dos correspondentes agravos de instrumentos, que quase sempre acabam ocorrendo. ${ }^{223}$

Voltando à tramitação conjunta do PL 3267/2000 com o PL168/99, certo é que o Poder Executivo, em 13/09/2000, pelo Aviso 1516/00, solicita o cancelamento da urgência constitucional, renovando-o, todavia, em 19/09/2000. Novo cancelamento da urgência em 29/11/2000, com renovação em 10/04/2001.

Como se viu, nesse ínterim, no bojo do já referido PL 168/99, seu proponente, o Deputado Jacques Wagner, no dia 11 de abril de 2001, solicitou ao Presidente da Câmara, Aécio Neves, a retirada de seu projeto de lei, o que foi deferido por despacho do dia 17 de abril, no qual também foi determinada a distribuição do PL n³267/00 (“o da transcendência"), até então apensado àquele, encaminhando esse último às Comissões de Trabalho, de Administração e Serviço Público e de Constituição e Justiça e de Redação.

Afinal, em 27/04/2001 foi designado relator do PL nº 3267/2000 na Comissão de Constituição e Justiça e de Cidadania, ônus atribuído à Deputada Zulaiê Cobra, cujo parecer, datado de 30 de maio de 2001, ensejou a conclusão da Comissão em $05 / 06 / 2001 .^{224}$

É importante destacar o conteúdo do voto da Deputada Zulaiê Cobra, in verbis:

\begin{abstract}
II - VOTO DA RELATORA
O projeto introduz novo requisito para a admissibilidade do recurso de revista, a "transcendência", que se assemelha à arguição de relevância, que já existiu em nosso ordenamento jurídico, à época limitada aos recursos endereçados ao Supremo Tribunal Federal - STF.
\end{abstract}

\footnotetext{
${ }^{223}$ Neste projeto de lei e noutros têm sido comum asserções questionando a necessidade de fundamentar decisões e despachos judiciais, seja a propósito da admissibilidade de recursos, em geral, nos juízos a quo e ad quem e, particularmente, seja dos de revista, ou ainda, quanto aos respectivos julgamentos finais, parecendo querer significar perda de tempo ou coisa semelhante. Há, todavia, manifesto descompasso com o inciso IX do art. 93 da Constituição, que exige alguma ou mínima fundamentação em todas as decisões do Poder Judiciário, sob pena de nulidade, admitindo-se, apenas, simplificação da enunciação dos fundamentos, como ocorre na certidão de julgamento do processos submetidos ao sumaríssimo (art. 893, § $1^{\circ}$, IV, da CLT).

${ }^{224}$ Reitere-se que as datas e eventos da tramitação dos projetos de lei 168/1999 (do Legislativo) e 3267/2000 (do Executivo) são encontráveis no sitio da Câmara dos Deputados, já mencionado às fls. 67 e 72 , respectivamente, deste capítulo.
} 
Não há, porém, previsão constitucional para fundamentar a arguição de relevância ou transcendência da matéria a ser submetida ao Tribunal Superior do Trabalho - TST, conforme previsto no projeto do Poder Executivo.

Saliente-se que a Reforma do Judiciário, aprovada na Câmara dos Deputados, introduz instrumento semelhante apenas para o Supremo Tribunal Federal. Isso significa que essa Casa já se manifestou sobre a matéria e decidiu que tal instituto deve estar restrito a nossa Corte Suprema.

Aliás, toda a exposição de motivos que acompanha a mensagem $n^{\circ} 830 / 00$ (rectius: $\mathrm{n}^{\circ}$ 831/00) do PL $n^{\circ} 3267$, de 2000 faz referência expressa ao Supremo Tribunal Federal. Não há menção ao Tribunal Superior do Trabalho.

A comparação com a Suprema Corte Americana, na exposição de motivos, é temerária uma vez que os sistemas jurídicos e judiciários americanos e brasileiros são bastante diversos. Transpor para o nosso ordenamento jurídico um instrumento existente em outro ordenamento, sem a necessária adaptação, pode gerar mais problemas do que solucioná-los.

Saliente-se que a exposição de motivos frisa o papel da Suprema Corte Americana que poderia, a grosso modo, ser comparada ao nosso Supremo Tribunal Federal, jamais ao Tribunal Superior do Trabalho.

A mais alta corte trabalhista não é a última instância da jurisdição trabalhista. Isso significa que as partes, mesmo que seus recursos não sejam conhecidos pelo TST em virtude da "transcendência", podem ainda recorrer ao Supremo Tribunal Federal, que não possui instrumento semelhante, até o presente momento.

Assim, o projeto pode não apresentar o efeito pretendido, apenas transferindo recursos de um Tribunal para outro.

Além disso, o termo "transcendência" não nos parece termo juridicamente aplicável, em virtude da possibilidade de ampla conceituação, e a definição de "transcendência" presente no $\S 1^{o}$ do projeto pode gerar controvérsia na sua interpretação.

A "transcendência jurídica" é definida como "desrespeito patente aos direitos humanos fundamentais". Na prática, ao contrário do pretendido, isso significa que nenhum recurso trabalhista deixará de ser apreciado pelo TST, pois direitos humanos fundamentais incluem todos os direitos trabalhistas.

Ocorre normalmente a confusão quanto aos direitos humanos fundamentais, pois muitos acreditam que apenas os direitos e garantias individuais são direito fundamentais.

Tal posição está equivocada. Com efeito, os primeiros direitos fundamentais a serem positivados e reconhecidos pelos Estados foram os direitos individuais ou as liberdades públicas, que visam à proteção do indivíduo perante o Estado. 
A evolução natural dos direitos fundamentais foi a proteção dos direitos sociais, pois já não bastava a não interferência do Estado para garantir a dignidade humana. Tornou-se necessária a atuação positiva do Estado para garantir os direitos sociais. Nesse sentido, o direito do trabalho é considerado direito humano fundamental.

Assim, a transcendência jurídica mencionada engloba os direitos trabalhistas, ou seja, toda a matéria submetida ao TST.

Além disso, a definição de "transcendência política" nada mais é que complementação da jurídica, uma vez que o princípio federativo e a harmonia dos Poderes são matérias jurídicas, estando constitucionalmente previstas.

De qualquer forma, apesar da tentativa de definir a "transcendência", $o$ $\S 1^{\circ}$ do art. 896-A do projeto poder ser interpretado de maneira subjetiva, gerando a instabilidade das relações jurídicas.

A redação dos parágrafos $2^{\circ}$ e $3^{\circ}$ do mencionado artigo do projeto é confusa, dando margem a interpretação divergentes.

$O \S 2^{\circ}$ concede prazo extra para que a parte supra "o não conhecimento de pressuposto extrínseco do recurso", caso a decisão recorrida contrarie a jurisprudência do tribunal relativa à questão transcendente.

Deduz-se que a parte tenha prazo complementar para que fundamente o seu recurso na questão transcendente, todavia não está clara a redação $e$, portanto, sujeita a entendimento diverso.

$O \S 3^{\circ}$ determina que o recurso fundamentado em aspectos processuais não será conhecido, salvo se violada norma constitucional. É feita também exceção para a regra gera quando "o tema de fundo estiver pacificado em sua jurisprudência no sentido da decisão proferida pelo tribunal inferior". Isso significa que, se a decisão recorrida estiver de acordo com a jurisprudência do tribunal, o recurso será conhecido, mas, nesse caso, sequer haveria necessidade de recurso, que serviria apenas para confirmar a decisão já prolatada pelo Tribunal Regional.

Por último, o art. $2^{\circ}$ do projeto determina que o TST regulamente "o procedimento de seleção dos recursos transcendentes e de uniformização na aplicação dos critérios de transcendência”. Tal determinação é inconstitucional, pois fere o princípio da separação dos poderes.

Além disso, o direito processual é de competência privativa da União (art. 22 da Constituição Federal) e, portanto, cabe ao Congresso Nacional dispor sobre a matéria (art. 48 da Constituição Federal). O artigo representa verdadeira delegação de competência, sem contudo observar as regras constitucionais específicas sobre esse tipo de elaboração legislativa (art. 68 da Constituição).

A técnica legislativa do projeto também mereceria reparos, pois, entre outros aspectos, o art. $1^{o}$ determina que o acréscimo legal seja feito ao Decreto-lei $n^{\circ} 5452 / 43$, que apenas aprovou a Consolidação das Leis do Trabalho e com ela não se confunde. A referência deveria ser feita à CLT. 
Diante do exposto opinamos pela inconstitucionalidade e injuridicidade e, no mérito, pela rejeição do $P L n^{\circ} 3267$, de 2000, restando prejudicada a análise da técnica legislativa.

Sala da Comissão, em 30 de maio de 2001.

Ao que tudo indica, esse contundente parecer representou um balde de água fria para o sucesso político do projeto de lei, tanto assim que, apesar dos líderes dos partidos políticos haverem solicitado urgência na sua tramitação, em 31 de maio de 2001, fato é que o Plenário da Câmara, em 20 de junho subsequente, rejeitou a urgência.

O então líder do Governo, Deputado Arnaldo Madeira, e dos principais partidos encaminharam novo pedido de urgência em 29 de agosto de 2001, o qual, no entanto, sequer foi apreciado pelo Plenário da Câmara, pois, em 10 de setembro de 2001, o Presidente da República, pela Mensagem 969, solicitou a retirada do Projeto de Lei 3267, de 2000.

À esta altura, todavia, o Poder Executivo já havia editado, em 05 de setembro de 2001, a Medida Provisória 2226, que tratava da transcendência e incluía outra tema, como se verá em seguida.

Note-se bem que, pelo menos para o Congresso Nacional, urgência da matéria não existia no projeto de lei, o que leva a pensar que, se a matéria da medida provisória era a mesma do projeto, os representantes do povo não haveriam de aceitar a existência de urgência na apreciação da medida provisória.

Tudo isso, no entanto, como se verá, foi relegado às calendas, pois a EC 32/01 alterou a sistemática constitucional desse tipo normativo, tendo sido criada "regra de transição" para as medidas editadas anteriormente, incluída a da transcendência, portanto. 


\subsection{A Medida Provisória 2226, de 05 de setembro de 2001 e seu estágio atual}

Em 04 de setembro de 2001, invocando o art. 62 da Constituição Federal, que, em caso de relevância e urgência, prevê a possibilidade de o Presidente da República adotar Medida Provisória, o Presidente Fernando Henrique Cardoso, pela Mensagem $\mathbf{n}^{\circ}$ 956 (fl.17) ${ }^{225}$, encaminhou para deliberação dos Membros do Congresso Nacional o texto da Medida Provisória $n^{\circ}$ 2226, publicada no Diário Oficial da União, Edição Extra, Seção I, de 05 de setembro de 2001, páginas 17 e 18, que "Acresce dispositivo à Consolidação das Leis do Trabalho, aprovada pelo Decreto-Lei no 5.452 , de $1^{\circ}$ de maio de 1943, e à Lei n 9.469, de 10 de julho de 1997’. Esta Media Provisória está vazada nos seguintes termos:

\section{MEDIDA PROVISÓRIA No 2226, DE 4 DE SETEMBRO DE 2001}

Acresce dispositivo à Consolidação das Leis do Trabalho, aprovada pelo Decreto-Lei $n^{o}$ 5.452, de $1^{o}$ de maio de 1943, e à Lei $n^{o}$ 9.469, de 10 de julho de 1997.

O PRESIDENTE DA REPÚBLICA, no uso da atribuição que lhe confere o art. 62 da Constituição. Adota a seguinte Medida Provisória, com força de lei:

Art. $1^{\circ}$ A Consolidação das Leis do Trabalho, aprovada pelo Decreto-Lei $n^{\circ}$ 5.452, de $1^{\circ}$ de maio de 1943, passa a vigorar acrescida do seguinte dispositivo:

“Art. 896-A. O Tribunal Superior do Trabalho, no recurso de revista, examinará previamente se a causa oferece transcendência com relação aos reflexos gerais de natureza econômica, política, social ou jurídica." $(N R)$

Art. $2^{\circ}$ O Tribunal Superior do Trabalho regulamentará, em seu regimento interno, o processamento da transcendência do recurso de revista, assegurada a apreciação da transcendência em sessão pública, com direito de sustentação oral e fundamentação da decisão.

Art. $3^{\circ} \mathrm{O}$ art. $6^{\circ}$ da Lei $n^{\circ} 9.469$, de 10 de julho de 1997, passa a vigorar acrescido do seguinte parágrafo, renumerando-se o atual parágrafo único para $\$ 1^{o}$ :

" $\$ 2^{\circ} \mathrm{O}$ acordo ou transação celebrada diretamente pela parte ou por intermédio de procurador para extinguir ou encerrar processo judicial, inclusive nos casos de extensão administrativa de pagamentos postulados em juízo, implicará sempre a responsabilidade de cada uma das partes

\footnotetext{
${ }^{225}$ Obteve-se no Congresso Nacional, por intermédio da Secretaria-Geral da Mesa, cópia física da Medida
} Provisória 2226/2001, de fls. 01 usque 34, por isso que é feita a indicação das páginas. 
pelo pagamento dos honorários de seus respectivos advogados, mesmo que tenham sido objeto de condenação transitada em julgado" (NR)

Art. $4^{o}$ Esta Medida Provisória entra em vigor na data de sua publicação.

Brasília, 4 de setembro de 2001; $180^{\circ}$ da Independência e $113^{\circ}$ da República.

A Mensagem Presidencial se fez acompanhada da Exposição de Motivos no 00024 - MTE AGU (fls. 18/20), assinada pelo Ministro de Estado do Trabalho e Emprego, Francisco Dornelles, e pelo Advogado-Geral da União, Gilmar Ferreira Mendes, o que confirma asserção feita à fl. 69 sobre a quase inexplicável intervenção do Ministro do Trabalho e Emprego na justificativa de norma eminentemente processual, inclusive sem o concurso do Ministro da Justiça, o que seria o natural que acontecesse. No lugar deste, porém, depara-se com a intervenção do Advogado-Geral da União, o qual, é notório, antes de ocupar este cargo, atuou na Casa Civil da Presidência da República (Subchefia de Assuntos Jurídicos), tendo como seu assessor Ives Gandra da Silva Martins Filho, à época, ainda nos quadros do Ministério Público do Trabalho.

É conveniente transcrever os termos desta exposição de motivos, ipsis verbis, para que se faça a necessária comparação com a peça semelhante oferecida por ocasião do encaminhamento do referido PL n. ${ }^{\circ}$ 3267/2000, objeto do item anterior. Vejam-se, pois:

Excelentíssimo Senhor Presidente da República,

Tenho a honra de submeter à apreciação de Vossa Excelência projeto de medida provisória, que acresce dispositivo à Consolidação das Leis do Trabalho-CLT.

Referido acréscimo deve-se à necessidade urgente e inadiável de viabilização do funcionamento do Tribunal Superior do Trabalho como Corte Suprema de resguardo e uniformização da legislação trabalhista.

O dispositivo consta do PL $n^{\circ} 3697 / 00^{226}$, que por três vezes contou com pedido de urgência constitucional, sem que o Congresso Nacional tivesse examinado a questão. Daí a sua veiculação por medida provisória, dada a urgência e relevância da matéria.

\footnotetext{
${ }^{226}$ A indicação do projeto de lei está equivocada, pois o correto é PL no 3267/2000, tal como exaustivamente visto e analisado anteriormente. Aliás, no mesmo equívoco de indicação do projeto de lei incidiram Wagner D. Giglio (Direito processual do trabalho. 14. ed. São Paulo: Saraiva, 2005. p. 437 e O requisito prévio da transcendência. In Revista LTr. 66-01/18 ) e Carlos Henrique Bezerra Leite (Curso de direito processual do trabalho. 8. ed. São Paulo: LTr, 2010. p. 796-797). Ademais, com demonstrado e pode ser conferido na tramitação do PL 3267/2000, como o Congresso Nacional não aceitou o regime de urgência, antes de terminado o respectivo prazo o Executivo retirava a urgência e a repropunha, manobra que não surtiu efeitos no momento em que a Comissão de Constituição e Justiça emitiu parecer pela inconstitucionalidade do projeto de lei, daí precipitando o oferecimento da medida provisória.
} 
O Tribunal Superior do Trabalho encontra-se, atualmente, em situação de colapso, pela total incapacidade de fazer frente ao volume descomunal de processos que lhe chegam diariamente. Mesmo tendo julgado mais de 120.000 processos no ano de 2000, terminou o ano com um saldo de 140.000 aguardando julgamento. Atualmente, cada um de seus ministros possui um estoque de 10.000 processos para julgar. $O$ Tribunal não dispõe sequer de espaço físico para guardar tamanha quantidade de processos, tendo alugado um prédio só para esse fim e sendo obrigado a alugar um segundo com a mesma destinação, em face do comprometimento das estruturas do prévio ora alugado.

O STF e o STJ encontram-se em situação semelhante, ainda que não tão dramática no que diz respeito à precariedade de instalações, e tem se verificado que a técnica a ser adotada para o desafogamento dos Tribunais Superiores, simplificação dos recursos e caracterização dessas Cortes como instâncias extraordinárias é a da demonstração da relevância federal ou transcendência política, social, econômica ou jurídica das causas que merecerão a apreciação pelos Tribunais Superiores. ${ }^{227}$

A inserção dessa espécie de requisito para a admissibilidade dos recursos de natureza extraordinária é de suma importância para não vulgarizar os tribunais superiores. Se todos os processos acabarem desembocando nas Cortes Superiores, o que era extraordinário passa a ser ordinário, com a desenganada intenção das partes de rediscutir indefinidamente as questões nas quais litigam. ${ }^{228}$

As Supremas Cortes Americana e Argentina, apenas para dar dois exemplos no continente americano, adotam tal técnica, ao escolher os processos que irão julgar, conforme sua relevância. Essa seleção permite a apreciação consciente e aprofundada das questões de maior importância para a sociedade, dando-se uma sinalização clara para as instâncias inferiores, sem se perder numa avalanche de processos repetitivos, com julgamentos padronizados, o que podem distorcer a adequação da hipótese fática à tese jurídica albergada pelo Tribunal.

Caberia, nesse contexto, à parte demonstrar a transcendência política, social, econômica ou jurídica da causa para que o TST a examine. ${ }^{229}$

Como em nosso sistema jurídico o duplo grau de jurisdição já assegura às partes revisão, por um colegiado, da decisão proferida pelo juiz singular, obtendo-se julgamento integral da causa, com reexame de fatos e provas e do direito aplicável à hipótese, conclui-se que os tribunais superiores não têm a missão de fazer justiça, no sentido de reexaminar a causa, mas de garantir a aplicação uniforme do direito federal em todo o território nacional. Assim, a missão transcende o interesse das partes, ligando-se à defesa dos interesses do Estado Federado, de que suas

\footnotetext{
${ }^{227}$ Este parágrafo corresponde, salvo pequenas modificações introdutórias, ao primeiro da exposição de motivos do PL 3267/2000. Nas Medidas Provisórias a exposição de motivos é fundamental para a fixação da interpretação da norma jurídica criada, mormente durante o período anterior à confirmação legislativa.

${ }^{228}$ Este parágrafo corresponde, exatamente, ao segundo da exposição de motivos do PL 3267/2000.

${ }^{229}$ Este parágrafo corresponde, exatamente, ao sétimo da exposição de motivos do PL 3267/2000.
} 
normas não sejam desobservadas por alguma das unidades que compõem a Federação. ${ }^{230}$

Daí que apenas as questões que transcenderem o interesse das partes, para afetar o próprio interesse da sociedade organizada em Estado Federal, é que merecerão ser julgadas pelas Cortes Superiores. E caberá a essas Cortes, com seu poder discricionário, aquilatar se a questão concreta se revela transcendente. Do contrário, continuarão os tribunais superiores a funcionar como $3^{a}$ ou $4^{a}$, instância ordinária, julgando de forma sumária os processos que lhes chegam, em sistema que apresenta maior discricionariedade do que o que se adotaria explicitamente. ${ }^{231}$

Com a adoção do critério de transcendência das questões federais, poderão os tribunais superiores ter condições de apreciar com tranquilidade, segurança, consciência e precisão as causas que lhes forem dirigidas, dedicando seu tempo àquelas que, efetivamente, terão repercussão tal na comunidade, que exigem detida análise de todos os aspectos que a envolvam, de modo a que a solução seja a que melhor atenda aos interesses da sociedade. ${ }^{232}$

A media assegura as garantias mínimas estampadas nos arts. $5^{\circ}, L V$, e 93, IX, da Constituição Federal, ao dispor que o TST, ao disciplinar o processamento da transcendência em seu regimento interno, deve garantir que a transcendência seja apreciada em sessão pública, com fundamentação e direito de sustentação oral. ${ }^{233}$

Por outro lado, além daquela alteração na Consolidação das Leis do Trabalho, propõem-se ,também, o acréscimo de um parágrafo ao art. $6^{\circ}$ da Lei $n^{\circ}$ 9.469, de 10 de julho

de 1997, para disciplinar a responsabilidade pelo pagamento de honorários de advogado, quando as partes que litigam em juízo firmarem acordo ou transação para extinguir ou encerrar o processo judicial.. ${ }^{234}$

Respeitosamente,

${ }^{230}$ Este parágrafo corresponde, exatamente, ao nono da exposição de motivos do PL 3267/2000.

${ }^{231}$ Este parágrafo corresponde, exatamente, ao décimo da exposição de motivos do PL 3267/2000.

${ }^{232}$ Este parágrafo corresponde, exatamente, ao décimo primeiro da exposição de motivos do PL 3267/2000.

${ }^{233}$ Este parágrafo representa total guinada de pensamento ou estratégia, em comparação com a que foi adotada na exposição de motivos do PL 3267/2000, que preconizava a desnecessidade de justificar a razão pela qual o Tribunal deixava de apreciar a causa desprovida de repercussão geral. E, como se disse, com total desconhecimento do inciso IX do art. 93 da CF. E já adiantando algum comentário, oportunamente mais detalhado, sustentação oral não implica, necessariamente, maior ou melhor respeito ao contraditório e à ampla defesa, haja vista, por exemplo, que nos agravos de instrumento não há sustentação oral e, considerando-se o processo civil, esse tipo de recurso tem espectro de aplicação maior do que no processo do trabalho.

${ }^{234}$ Este último parágrafo, por óbvio, cuida de matéria diversa da transcendência e, diferentemente de como ela foi abordada na exposição de motivos, não exibe qualquer justificativa de relevância e urgência para os fins do art. 62 da CF, tanto que, afinal, com se verá oportunamente o STF, liminarmente reputou inconstitucional o art. $3^{\circ}$ da MP 2226/2001, no julgamento da medida cautelar da ADI 2527-9-MC, DJU 27/11/2007. 
A Medida Provisória 2226/2001 foi autuada no Congresso Nacional aos cinco dias do mês de setembro de 2001, em cumprimento ao disposto no Art. 2 ${ }^{\text {, }}$ "caput", da

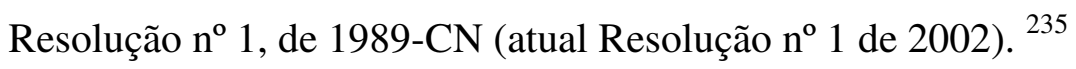

À essa época, as medidas provisórias eram encaminhadas ao Congresso Nacional pelo Presidente da República e, após admissibilidade prévia sobre a urgência e relevância, a ser feita por comissão mista de Deputados e Senadores, devia ocorrer a discussão e aprovação, isto é, a apreciação pelos parlamentares, em votação conjunta da Câmara dos Deputados e do Senado. A medida provisória precisa ser transformada em lei..

Este modus legis generandi, foi alterado pela Emenda Constitucional $n^{\circ} 32 / 2001$, que deu nova redação ao art. 62 da Constituição Federal, ou seja, de acordo com o respectivo $\S 8^{\circ}$, as medidas provisórias passaram a ter sua votação separada em cada uma das Casas do Parlamento, iniciando-se pela Câmara dos Deputados, depois que uma comissão desta Casa examinasse a prévia admissibilidade sobre o atendimento dos pressupostos constitucionais. $\left(\$ 5^{\circ}\right) .{ }^{236}$

O parecer que vem referido no $\S^{\circ}$ precederá a votação de projeto de lei de conversão, que altere ou, não, a MP. ${ }^{237}$

Aqui, todavia, deparamo-nos com intrigante situação, verdadeiro "nó não desatado," que foi criado pela Emenda Constitucional n $n^{\circ} 32$ de 11 de setembro de 2001, problema que diz respeito à votação, à aprovação ou à rejeição das medidas que já haviam sido editadas e que estavam em vigor. ${ }^{238}$

Com efeito, o art. $2^{\circ}$ dessa Emenda estabeleceu que as "medidas provisórias editadas em data anterior à da publicação desta emenda continuam em vigor até que

\footnotetext{
${ }^{235}$ Vide, a propósito das medidas provisórias e sua nova sistemática, implantada com a EC nº32/01, MORAES, Alexandre de. Direito constitucional. 24. ed. São Paulo: Atlas, 2009. p. 670-687.

${ }^{236}$ Vide, a respeito, SILVA, José Afonso da. Curso de direito constitucional positivo. 31. ed. São Pauyulo: Malheiros Ed., 2008. p. 532, quando, para a legitimidade das medidas provisórias, alude ao atendimento, tanto de pressupostos formais (relevância e urgência), como materiais (temas limitados) e procedimentais (tramitação diferenciada).

${ }^{237}$ Id. Ibid., p. 534.

${ }^{238}$ No caso concreto, a MP 2226/01, além de ser anterior, ostenta outro elemento embaraçoso: a matéria tratada é processual trabalhista e civil. De fato, apesar de a $\mathrm{EC} \mathrm{n}^{\circ} 32 / 01$ haver proibido a edição de medida provisória em matéria processual (letra "b" do inciso I do art. 62 da CF), na prática, essa Emenda Constitucional nada mais fez do que amoldar-se à jurisprudência já firmada pelo Supremo Tribunal Federal, nessa linha de proibição, por ocasião do julgamento da ADI 1910- MC, em 22/04/99, vale dizer, mais de ano antes. A discussão sobre a constitucionalidade da MP 2226/01 será retomada no capítulo IV.
} 


\section{medida provisória ulterior as revogue explicitamente ou até deliberação definitiva do} Congresso Nacional.”(g.n.)

Pois bem, até a presente época, janeiro de 2011, passados mais de nove anos, a Medida Provisória 2226/2001 não foi votada pelo Congresso Nacional, situação que vai de encontro aos mais elementares princípios do Estado Democrático de Direito, pois toda lei ou medida dotada da respectiva eficácia há de ser discutida e aprovada pelos representantes do povo, de quem emana todo poder. Noutras palavras, a concretização de uma norma legal depende da respectiva submissão ao procedimento legislativo previsto nos arts. 59 "usque" 69 da Carta Política, sob pena de flagrante inconstitucionalidade.

A esse respeito é oportuna a lição de Michel Temer, segundo o qual, "a medida provisória não é lei, é ato que tem "força da lei"”, explicando que lei "é ato nascido no Poder Legislativo que se submete a um regime jurídico predeterminado na Constituição, capaz de inovar originariamente a ordem jurídica, ou seja, criar direitos e deveres," e, arrematando, sustenta em seguida que a

medida provisória também cria direitos e obrigações, também obriga, porque o constituinte permitiu exceção ao princípio doutrinário segundo o qual legislar incumbe ao Legislativo. Não é lei, porque não nasce no Legislativo. Tem força de lei, embora emane de uma única pessoa, é unipessoal, não é fruto de representação popular, estabelecida no art. $1^{\circ}$, parágrafo único"("todo poder emana do povo")", da Carta Magna. ${ }^{239}$

Difícil conceber Estado Democrático de Direito sem que se respeite o princípio da representação popular na função de criar normas jurídicas (essencialmente nas fases de discussão e de aprovação), visto que, ressaltando-se a excepcionalidade da hipótese, por princípio, não se trata de mister típico do Poder Executivo. ${ }^{240}$

De outro lado, não é razoável nem justificável que o Congresso Nacional, passado tanto tempo, não tenha, ainda, apreciado a Medida Provisória 2226/01, mesmo porque o

\footnotetext{
${ }^{239}$ TEMER, Michel. Elementos de direito constitucional. 22. ed. São Paulo: Malheiros Ed., 2007. p. 153.

${ }^{240}$ FERREIRA, Luís Pinto. Princípios gerais do direito constitucional moderno. 6. ed. São Paulo: Saraiva, 1983. v. 1, p. 205 já havia alertado para a tendência à democracia mista, não apenas, a representativa ("vocação íntima do povo de influir mais decisivamente no seu próprio destino"), em boa medida adotada em nossa Carta Política, o que reforça a tônica constitucional da limitação da atuação legiferante do Poder Executivo, que não pode submeter o Congresso Nacional ao papel de mero órgão de chancela de "sua vontade com força de lei", (sendo pior o caso das MPs, pois ela é posterior).A situação peculiar da MP 2226/01 é ainda mais grave, pois a oportunidade de chancela do Legislativo está indefinida no tempo, o que escapa de qualquer lógica do razoável e do aceitável.
} 
acima transcrito art. $2^{\circ}$ da EC $n^{\circ} 32 / 01$ há de ser interpretado apenas como autorizador de ampliação da eficácia das medidas provisórias editadas antes dela.

Reitere-se que a vigência temporal pretérita desse tipo especial normativo era de 30 dias, com possibilidade de reedições subsequentes, as quais, atualmente, estão vedadas, pois só há autorização constitucional de uma única prorrogação.

Por óbvio, a EC n 32/01 não exclui as medidas provisórias anteriores à submissão ao procedimento legislativo, ou seja, pela necessária e insubstituível aprovação pelos representantes do povo, ainda mais quando ali se faz menção expressa à "deliberação definitiva do Congresso Nacional" (g.n).

Nem a provisória (a de admissibilidade liminar) houve!

Afinal, essa espécie normativa excepcional, antes e agora, tem ínsita na sua essência a possibilidade de rejeição tácita pelo Congresso Nacional $^{241}$, caso sobre ela não se delibere nos prazos estabelecidos. ${ }^{242}$

Há, portanto, inescusável omissão, flagrantemente inconstitucional, do Congresso Nacional, ao não apreciar a Medida Provisória 2226/01 e cinquenta e uma outras tantas, diga-se, a bem da verdade, que foram editadas antes da EC $n^{\circ} 32 / 01$, tal como se pode conferir no sítio do Senado Federal. ${ }^{243}$

Essa atitude inerte é tão ou mais grave quando se constata que, em última análise, ela significa submissão do Poder Legislativo ao Poder Executivo, o que também não tem sustentação constitucional. $^{244}$

\footnotetext{
${ }^{241}$ SILVA, José Afonso da. op. cit., p. 533-534.

${ }^{242}$ MORAES, Alexandre de.op. cit., p. 674, com destaque para a nota de rodapé 2, que invoca precedente do STF no sentido da inconstitucionalidade de previsão de aprovação legislativa por decurso de prazo $\left(\mathrm{RE} \mathrm{n}^{\circ}\right.$ 212.596/SP - Pleno - Rel. Min. Cezar Peluso.

${ }^{243}$ SENADO FEDERAL. Portal Atividade Legislativa. Comissões Mistas. Disponível em: $<$ http://www.senado.gov.br/atividade/comissoes/default.asp?origem=CN>. Acesso em: 23 set. 2010. Também pode ser obtido no Senado Federal quadro de todas as Medidas Provisórias em tramitação, especialmente aquelas anteriores à EC 32/01. SENADO FEDERAL. Disponível em: $<$ http://legis.senado.gov.br/sil-pdf/Comissoes/Mistas/MP/Resumo/201009130000.pdf>. Acesso em: 23 set. 2010.

${ }^{244}$ Há artigo deste Mestrando, sob o título "Omissões...”, que aborda essa incompreensível situação envolvendo, particularmente, a tramitação da MP 2226/01, na obra coletiva organizada por Jorge Cavalcanti Boucinhas Filho, José Luciano de Castilho Pereira e Marcos Fava, entitulada $O$ direito material e processual do trabalho dos novos tempos: estudos em Homenagem ao Professor Estêvão Mallet. São Paulo: LTr, 2009.p. 359-365.
} 
Essa mesma passividade conspira contra a independência e harmonia que deve existir entre os Poderes do Estado, enfim, a demarcação e divisão orgânica das funções estatais essenciais, as quais, como anotam Luiz Alberto David Araujo e Vidal Serrano Nunes Júnior, têm como matriz subjacente "criar um sistema de compensações, evitando que uma só pessoa, ou único órgão, viesse a concentrar em suas mãos todo o poder do Estado"245 $^{245}$

Parada como está a tramitação dessas 52 Medidas Provisórias anteriores à EC n ${ }^{\circ}$ 32/01, cristaliza-se situação em que o Executivo exerceu poder sem limite e sem o controle parlamentar comum, o que nunca aconteceu antes nem prevalece agora, mas, insista-se, inexplicavelmente vale para essas 52 "medidas especiais", dentre elas a "nossa" 2226/01.

Encerrando este item, deixa-se claro que, após a autuação da MP 2226/01 (fl.01), seguem-se xerocópias das páginas 17 e 18 da edição extra do DOU do dia 05 de setembro de 2001 na qual houve sua publicação (fls. 02/03), a apresentação dos membros da Comissão Mista incumbida de emitir parecer sobre a matéria (fls. 04/05), quadro resumido (fl.06) das emendas supressivas apresentadas perante a Comissão Mista, sendo três do Deputado Paulo Paim (sob os números 001, 003 e 004) e uma pelo Deputado José Antonio Almeida (002)

A $n^{\circ} 001$ (fl.07) pede a supressão do art. $1^{\circ}$ e diz que a MP não conta com o requisito de urgência e que a transcendência impediria "a continuidade do regular processo judicial trabalhista"; a n 002 (fl.008) pede a supressão dos arts. $1^{\circ}$ e $2^{\circ}$ e diz tratar-se de ressurreição da "arguição de relevância", não se podendo passar "cheque em branco" ao TST para impedir ou cercear os recursos de revista, "atribuindo-lhe função precípua deste Poder Legislativo"; a n 003 (fl.09) pede a supressão do art. $2^{\circ}$ e diz que a MP não atende o requisito de urgência na medida em que "remete ao TST a regulamentação da matéria, o que, necessariamente, não significa que o Tribunal poderá fazê-lo com urgência". ${ }^{246}$ A n ${ }^{\circ}$ 004 (fl.10) pede a supressão do art. $3^{\circ}$ e diz que o dispositivo "trata de limitar o direito a honorários advocatícios", constituindo desrespeito às "decisões judiciais. A medida, além de injusta, é inconstitucional".

\footnotetext{
${ }^{245}$ ARAUJO, Luiz Alberto David; NUNES JÚNIOR, Vidal Serrano. Curso de direito constitucional. São Paulo: Saraiva, 1998. p. 210.

${ }^{246} \mathrm{O}$ longo tempo que se passou entre a data desta emenda supressiva, apresentada em 10 set. 2001, até esta parte (jan. 2011) está a revelar que o antigo Deputado Paulo Paim, atualmente Senador, teve premonição que vem se confirmando, pois o TST não regulamentou a transcendência.
} 
Às fls. 11/15 seguem-se ofícios indicando substituição de senadores e de deputados na Comissão Mista.

Às fls. 16/20 (como antes referido) encontram-se o original da Medida Provisória, assinada pelo Presidente da República, a Mensagem de encaminhamento ao Congresso Nacional e a Exposição de Motivos.

Ao depois, xerocópia da legislação citada (art. $6^{\circ}$ da Lei 9469, de 10 de julho de 1997, fl. 21) e o Aviso nº 1046 da Casa Civil sobre o encaminhamento da MP (fl.22).

Às fls. 23/26 novas indicações de substituição de Senadores e de Deputados para compor a Comissão Mista.

À fl. 27 está encartada xerocópia do DOU/ Poder Judiciário, do dia 25 de setembro de 2002, dando conta de adiamento, por pedido de vista, do julgamento da ADI 2527-9 Liminar, que foi proposta pelo Conselho Federal da Ordem dos Advogados do Brasil contra a MP 2226/01.

À fl. 28, outra xerocópia nesses mesmos termos, agora, do dia 08/11/022.

Às fls. 29/31 nova substituição de membros da Comissão Mista.

Finalmente, à fl. 32, encontra-se ofício do então Presidente da Câmara do Deputados, Aécio Neves, encaminhando, "para as providências que julgar pertinentes," ofício da Associação dos Juízes Federais do Brasil "solicitando providências no sentido de acelerar o processo de votação das 61 Medidas Provisórias editadas antes da promulgação da Emenda Constitucional no 32, de 2001”. Seguem-se a notícia do sítio da AJUFE e o ofício dirigido ao Presidente da Câmara dos Deputados (fls. 33/34).

O último andamento da tramitação da MP 2226/01, no qual consta a indicação da data de 16/04/2004, obtido junto ao já mencionado sítio do Senado Federal contém a seguinte situação: AGUARDANDO INCLUSÃO ORDEM DO DIA (g.n) ${ }^{247}$.

\footnotetext{
${ }^{247}$ SENADO FEDERAL. Projetos $e$ Matérias Legislativas. Disponível em: <http://www.senado.gov.br/sf/atividade/materia/detalhes.asp?p_cod_mate=48280>.. Acesso em: 27 dez. 2010, aguardando inclusão em ordem do dia, desde 16. 06.2004.
} 
Como se vê, não existe, até hoje, nem o parecer da Comissão Mista, antes e também agora constitucionalmente exigível e, tampouco, qualquer outro ato ordinatório da Presidência do Congresso com vistas ao cumprimento dessa exigência.

De se concluir, portanto, que, desenganadamente, é muito tênue a perspectiva de votação da Medida Provisória 2226/01.

É uma ferida constitucional não revelada ao público, quiçá de propósito, o que denigre os anseios de concretizar-se no Brasil um verdadeiro Estado Democrático de Direito.

Na prática, essa Medida Provisória é tida como se fosse uma lei, mas resulta de ato de vontade exclusiva do Chefe do Poder Executivo, situação que se reveste de despotismo inédito, sem sustentação constitucional.

\subsection{A Falta de Regulamentação da Transcendência pelo Tribunal Superior do Trabalho e a Opinião de alguns Ministros sobre essa matéria}

Como se viu no início deste capítulo, a Medida Provisória 2226/01 atribuiu ao Tribunal Superior do Trabalho, em seu regimento interno, "o processamento da transcendência do recurso de revista, assegurada a apreciação da transcendência em sessão pública, com direito a sustentação oral e fundamentação da decisão"

Ignoram-se os reais motivos que levam o Tribunal Superior do Trabalho (como um todo) para não cumprir o que lhe foi determinado pela medida provisória, conquanto se saiba que, desde o fim do primeiro semestre de 2010, a última "Comissão da Transcendência” (assim será identificada), criada pela Resolução Administrativa 1360/09, já tenha exposto seu ponto de vista, o qual, todavia, não foi submetido à totalidade da Corte, o que também é inexplicável, pois já se passaram mais de seis meses, tal como se verá mais abaixo. 
Alguns fatos concretos se apresentam, mas pouca luz há sobre esse intrigante impasse. As entrevistas feitas com alguns Ministros do TST ajudam a construir uma hipótese e a antever solução futura.

Certo é que, do dia 05 de setembro de 2001, quando publicada a MP, até a presente época (janeiro de 2011), o Tribunal Superior do Trabalho não cumpriu essa medida com força de lei, o que aos olhos dos chamados operadores do direito processual do trabalho, no mínimo, está a causar espécie, pois, em última análise, há situação continuada de descumprimento de norma jurídica, por mais por quase dez anos ininterruptos, por parte de uma Corte Superior da Federação.

Reconheça-se, no entanto, que o Tribunal Superior do Trabalho foi colocado numa situação embaraçosa porque, a depender de sua providência regimental, a Medida Provisória 2226/01, embora editada sob o influxo constitucional de induvidosas relevância e urgência, não tem efeito prático algum.

Noutras palavras, um órgão do Poder Judiciário, a quem não está atribuída a função de obstar a eficácia erga omnes de uma norma jurídica, em plena vigência, na prática, consegue inviabilizá-la, por tempo indeterminado, o que, nos termos da Carta Política e da legislação específica, só poderia ser feito por intervenção judicial do Supremo Tribunal Federal, em sede de controle concentrado da constitucionalidade, ainda que liminarmente, o que, sabe-se bem, ao contrário, não ocorreu no julgamento da liminar.

Ainda que alguns possam ver tintas fortes demais, ousa-se dizer que essa situação implica reconhecer, por vias indiretas, que o Tribunal Superior do Trabalho obsta o cumprimento de preceito com força de lei, o que, nada mais é do que usurpação dissimulada de competência da Suprema Corte e afronta à autoridade de sua decisão que, afinal, não suspendeu os arts. $1^{\circ}$ e $2^{\circ}$ da MP 2226/01.

Nem se diga sobre eventual inconstitucionalidade por omissão, que pode restar caracterizada pela falta de iniciativa para disciplinar a transcendência no regimento interno.

Tal como também mencionado antes, o Conselho Federal da Ordem dos Advogados do Brasil, em 14 de setembro de 2001, protocolou Ação Direta de Inconstitucionalidade, com pedido de liminar, contra todo o teor da Medida Provisória $2226 / 01$. 
O Supremo Tribunal Federal (compare-se a data da propositura da ADI - 14 set. 2001- ) levou quase exatos seis anos para concluir o julgamento da liminar, que só ocorreu no dia 16 de agosto de 2007, sendo certo que o respectivo acórdão só foi publicado no dia 23 de novembro desse mesmo ano ${ }^{248}$.

Considerado-se essa peculiar situação e até, com grande probabilidade de certeza, por motivos de ordem prática, o Tribunal Superior do Trabalho parece ter aguardado o desfecho do julgamento da liminar daquela ADI, tanto isso é verdade que, o plenário da Corte, pela Resolução Administrativa 1.272, do dia 22 de novembro de 2007, publicada no DJ de 27.11.2007, houve por bem formar a primeira Comissão Temporária de Ministros para que fosse apresentada a proposta de regulamentação do art. 896-A da CLT, tendo sido estipulado prazo até 29 de fevereiro de 2008 para que se ultimassem os trabalhos.

A comissão era integrada pelos Ministros Antonio José de Barros Levenhagen (Presidente), Horácio Raymundo de Senna Pires e Renato de Lacerda Paiva. ${ }^{249}$

Encerrado o prazo sem qualquer proposta, a comissão se dissolveu, conforme informações prestadas pelos referidos membros. ${ }^{250}$

Nada mais foi feito até que, em 13 de novembro de 2009 (vale dizer, quase exatos dois anos depois da Res. 1272/07), o plenário do Tribunal Superior do Trabalho, pela Resolução 1360, publicada no Diário Eletrônico da Justiça do Trabalho, resolveu constituir “Comissão Temporária, integrada pelos Exmos. Srs. Ministros João Oreste Dalazen (Presidente), Ives Gandra Martins Filho, Brito Pereira, Maria Cristina Irigoyen Peduzzi e Lélio Bentes Corrêa, destinada a estudar a viabilidade da regulamentação interna do disposto no art. 896-A da CLT, que instituiu o critério de transcendência para o exame prévio do Recurso de Revista" ${ }^{251}$

\footnotetext{
${ }^{248}$ Pode-se conferir a tramitação da ADI 2527 no sítio do SUPREMO TRIBUNAL FEDERAL. Disponível em: <http://www.stf.jus.br/portal/processo/verProcessoAndamento.asp?incidente=1970076>. Acesso em: 29 dez. 2010.

${ }^{249} \mathrm{O}$ inteiro teor desta Resolução $\mathrm{n}^{\circ} 1.272 / 07$ pode ser obtido no sítio do TRIBUNAL SUPERIOR DO TRABALHO. Resolução Administrativa $n . \quad 1272 . \quad$.Disponível em: <http://www.tst.jus.br/DGCJ/IndiceResolucoes/ResAdm/1272.html>. Acesso em: 23 set. 2010.

${ }^{250}$ Assim se manifestaram os componentes da Comissão, em entrevistas feitas nos dias 10,11 e 12 de novembro de 2009.

${ }^{251} \mathrm{O}$ inteiro teor desta Resolução $\mathrm{n}^{\mathrm{o}} 1.360 / 09$ pode ser obtido no sítio do TRIBUNAL SUPERIOR DO TRABALHO. Resolução Administrativa n. 1360, de 13 de outubro de 2009. Disponível em: <http://www.tst.jus.br/DGCJ/IndiceResolucoes/ResAdm/1360.pdf>. Acesso em: 10 jan. 2010.
} 
Diferentemente do que se deu com a Resolução Administrativa 1272/2007, acima referida, embora a última Resolução tenha definido tratar-se de uma "comissão temporária", não foi estipulado nenhum prazo final para a apresentação dos estudos sobre a regulamentação da transcendência.

Afinal, o que pensam alguns Ministros do Tribunal Superior do Trabalho sobre a transcendência?

A Medida Provisória 2226/01 tornou os membros dessa Corte protagonistas da regulamentação do recurso de revista, daí se justificando investigar como pretendem agir sobre o assunto e, afinal, como encaram a própria autuação do TST. Confiram-se as entrevistas feitas, observada a ordem de indicação dos Ministros, que respeita a antiguidade. $^{252}$

\section{MINISTRO IVES GANDRA MARTINS}

José Pedro - Ministro Ives Gandra Martins, afinal, o que V. Exa. tem a dizer sobre a transcendência?

Ministro - A idéia da transcendência foi dar um critério seletivo de recursos para enfrentar o volume crescente de processo que chegavam ao TST, não é diferente do STJ nem do Supremo. Hoje a carga de processos que chegam às Cortes Superiores supera infinitamente a capacidade dos Magistrados de enfrentarem esses processos, dando um mínimo de qualidade para os julgamentos. Veja o seguinte, tanto Cortes Supremas quanto Cortes Constitucionais do mundo inteiro, adotam critérios de seleção para julgamento de seus processos. Esse critério de seleção é um critério totalmente discricionário, mas que leva em conta, o que, basicamente: é matéria nova? não houve ainda pronunciamento da Corte sobre esse tema para definir, do ponto de vista de interpretação da Constituição como ela deve ser interpretada ou do ponto de vista de lei, como deve ser interpretada? Então, se justifica um pronunciamento. Se já houve pronunciamento, já cumpriu-se a missão do Tribunal Superior do Trabalho ou das Cortes Supremas, no caso, também, o STJ. Quando

\footnotetext{
${ }^{252}$ Infelizmente, por motivos de agenda, em viagem a Brasília, não foi possível ouvir todos aqueles Ministros que compunham essa nova comissão. Colheu-se, portanto, o depoimento de outros integrantes da Corte Maior Trabalhista. Todavia, Presidente da Comissão, Min. João Oreste Dalazen, houve por bem fornecer o voto prevalente sobre a regulamentação da transcendência, tal como se verá no seu devido momento.
} 
se adotou a MP 2226 de 2001, se tentou, em primeiro lugar, um projeto de lei já especificando os critérios, o que seria a transcendência política, econômica, jurídica e social. Esse projeto estava demorando na sua tramitação. Que fez o governo? Por duas vezes pediu urgência. O que justifica a edição de medida provisória, quando há necessidade de resolver o problema, há apresentação do pedido de urgência e não é atendido, então o governo apresentou a medida provisória, editou a medida provisória. A edição da medida provisória, já que ia ser um ato do Executivo, isolado, o que se fez, vamos, simplesmente, instituir o critério, mas não retirar do Tribunal Superior do Trabalho a definição do procedimento e a edição, e a definição de critérios. Ao mesmo, então, por um lado, respeitar o TST, não perder o momento histórico, respeitar o TST, na sua competência, e minimizar uma eventual, resistência da classe dos Advogados. Por isso é que se colocou no artigo segundo possibilidade de sessão pública com fundamentação e sustentação oral. Hoje, estou convencido de que foi um erro. Por que? Porque tentar compor com os advogados matéria de critério seletivo é algo inútil. Por que? Não querem, absolutamente, qualquer critério que diminua ou racionalize a prestação jurisdicional. Porque, como bem disse o próprio Ministro Nelson Jobim, quando do julgamento da ADIN sobre essa matéria, é questão de reserva de mercado. Querem, efetivamente, que o número de recursos seja grande para poder ter bastante campo atuação. Pois bem, uma vez editada a medida provisória, caberia ao TST regulamentar. A resistência, aqui no TST, é, fundamentalmente, por parte de um grupo minoritário. Por quê digo que há um grupo minoritário? Porque há, basicamente, três correntes aqui no Tribunal. Uma corrente que é radicalmente contra o próprio critério e quer que se revogue a medida provisória. Uma segunda corrente, que entende que é possível, mesmo com sustentação oral, fundamentação e sessão pública, mesmo assim, a mudança de discurso, a mudança de paradigma, faz com que você consiga reduzir e, mais ou menos, controlar o número de processos que chegam, para fazer aquilo que é a vocação do Juiz, que é julgar o processo que, uma vez selecionado - esse é importante ? -, esse o Juiz vai se dedicar, discutir o que tiver que discutir e fundamentar o que tiver que fundamentar. E há uma terceira corrente, que na verdade se soma a essa segunda, que diz que o critério tinha que ser mais radical. Portanto, que propõe, eventualmente, um projeto de lei, que retire a sustentação oral, fundamentação e sessão pública. O critério de seleção seria totalmente discricionário, como na Corte Suprema americana. Na verdade, vamos dizer assim, se cada corrente tem, mais ou menos, um terço de adeptos, que é mais ou menos isso, você tem um terço só do Tribunal que é contrário à transcendência, o resto é favorável, uns mais radicalmente, 
outros ainda aceitam algo mais palatável. Pois bem, o Ministro Milton, quando compôs essa comissão agora em outubro ele acabou adotando um critério infeliz, que foi o critério da antiguidade. Por que infeliz? Porque se ele antes consultou o Tribunal - quem concordava em criar a comissão? -, quem é contra a criação da comissão não poderia fazer parte da comissão. E o que está acontecendo é que esses que foram contrários à criação da comissão, entraram na comissão para fazer com que ela não funcione. Já manifestaram que querem um projeto de lei que acabe com a medida provisória. Isso não é a vontade majoritária do Tribunal. Portanto, estão dificultando o funcionamento dessa comissão. Pois bem, há dez dias atrás, eu ainda estava na Austrália, participando de um congresso, uma conferência, para discutir, Fourth International Conference on Judicial Training, e dois painéis me chamaram muito a atenção, pensando na questão da transcendência, que foram um painel de Case Management, gerenciamento processual e outro de Judicial Leadership, sobre como dirigir Tribunais. Pois bem, no Case Management, todos os painelistas, uma Juíza, uma Judge das Filipinas, outro do Paquistão e um dos EUA, disseram que, principalmente, nos países em desenvolvimento, como são e é o nosso, com uma mais ou menos recente democratização efetiva, criou-se uma ampliação de direitos, que faz com que aumente o acesso à Justiça. Então, aumenta a demanda de tal forma que o Judiciário não está em condições de receber tudo. Portanto, é necessário que se invista em gerenciamento (...), gerenciamento processual. E, principalmente, em Cortes Superiores, a natureza dessas Cortes Superiores, não é de Tribunal de Justiça, de ser mais uma instância. Não é direito do cidadão, mas do Estado Federado. Portanto, o que nós temos que fazer é mudar o modelo. Em vez de um modelo de quatro instâncias, ser um modelo de duas instâncias ordinárias - o cidadão tem direito ao duplo grau de jurisdição. À instância extraordinária vai caber aos Juizes dizerem: vou aproveitar esse caso, aproveitar para definir qual é a interpretação a ser dada ao dispositivo de lei. Então, essa foi a contribuição do painel Case Management. Agora, o segundo painel que me chamou muito a atenção, foi o do Judicial Leadership, um dos Judges que falou, era da Inglaterra, ele dizia o seguinte: quando se chega a um cargo de direção, você tem que delegar poderes. É impossível você gerenciar tudo; $90 \%$ da sua atividade vai ser administrativa ,10\% vai ser judicial. Você vai ter que julgar, dirigir, formar vontades colegiadas. Pois bem, ele dizia: Um Juiz, mesmo administrando, nunca deve esquecer que ele é Juiz. E, segundo, a atividade jurisdicional não se delega. Eu delego poderes em matéria administrativa. Hoje, no Tribunal Superior do Trabalho se delega jurisdição. Ninguém, em sã consciência, pode dizer que consegue julgar, por mês, 2.000 processos. Não julga. É o assessor que está decidindo; ele está 
assinando e referendando o que o assessor, com maior ou menor consciência, está propondo. Portanto, nós estamos fazendo algo que um Juiz, absolutamente, não pode fazer: delegar jurisdição. Adotando o critério de transcendência, a transcendência, a natureza dela, é de critério seletivo de caráter administrativo. Você não diz nem dos pressupostos intrínsecos nem extrínsecos, nem do mérito do recurso. Simplesmente, você vai dizer: Isto aqui justifica, do ponto de vista econômico, político, jurídico e social, um novo julgamento? É matéria nova? Sim. A decisão está indo contra a jurisprudência pacificada, sumulada do tribunal? Sim. É recurso que traz questão social, recurso do empregado em relação a direito constitucionalmente garantido? Sim - que é $20 \%$ do que chega aqui. É uma questão nova, que houve ofensa à constituição ou contrariedade à sumula, ou o valor econômico justifica, novo julgamento? Sim? Então, o tribunal aprecia. Portanto, essa triagem é de natureza administrativa, posso delegar aos assessores, eles vão ter que me convencer quais são os casos transcendentes e eu vou ter que convencer mais dois colegas, se for feito o julgamento na Turma. Portanto, hoje, muitos advogados reclamam do que está se fazendo no TST, dizendo: foi adotada a transcendência branca, ou seja, muitos Ministros mantêm, simplesmente, todos os agravos de instrumento por seus próprios e jurídicos fundamentos, em relação ao despacho agravado, ou transcrevendo ou fazendo mera remição. Portanto, o que eu tenho sustentado é que não é mais viável o Ministro estar receber 1.000 processos por mês. Portanto, tentar julgar mais, ou você compromete a sua saúde ou você compromete a sua consciência. É isso que está acontecendo no Tribunal.

José Pedro - Ministro, para terminar, muito interessante essa questão da delegação de competência judicial, que é um ponto sensibilíssimo, uma aparência de recurso que o advogado faz e uma aparência de julgamento da parte do Juiz, verdadeiro "faz de conta".

Ministro Ives - O despacho de admissibilidade, se você for ver vários Tribunais, é um negócio assim “chapadão”, sem maiores informações. Por que? Porque, como é um juízo de cognição incompleta, que pensa o Presidente do Tribunal? Bom, eu mando lá para cima, eles é que vão ver, pois, na verdade, quem tem que dar a última palavra são eles. Chega aqui, com a quantidade enorme de processos: Ah, eles já analisaram lá em cima, eu vou referendar. Então, joga para o outro, o outro joga para o um e ninguém decide. E você apreciou o mérito, porque, cada vez que eu mantenho uma decisão, em agravo de instrumento, porque a matéria estava sumulada e, em princípio, a decisão está de acordo com a súmula, isso é julgamento de mérito. Tanto que você pode entrar com ação rescisória. Tem sentença de mérito. Aí é que eu posso correr o risco de errar muito mais do 
que dizer assim: não vou analisar nenhum desses recursos, só aqueles que vão me servir de ensejo para eu poder fazer a prestação jurisdicional, do ponto de vista de Corte Superior, que é definir como é que deve ser interpretado direito.

José Pedro - Ministro, muito obrigado.

\section{MINISTRA MARIA CRISTINA PEDUZZI}

José Pedro - Ministra Cristina Peduzzi, em primeiro lugar, muito obrigado pela acolhida deste estudante. Como V. Exa. sabe, estou fazendo trabalho de mestrado a respeito da transcendência; é um problema que se arrasta desde 2001. Esse nó vai ser desatado? Como que vê, V. Exa., esse problema, principalmente, pela ótica da advocacia, posto que V. Exa. é oriunda do quinto constitucional da advocacia.

Ministra Cristina - Bom, se depender de mim, não será regulamentado o instituto da transcendência. E a minha opinião é a seguinte: até compreendo que a intenção de quem elaborou o projeto, que resultou na medida provisória, tenha sido a melhor possível. Ocorre que teve como inspiração a Corte Suprema americana. Lá, não há necessidade de a rejeição, de um exame de um recurso ser fundamentada, então, a Corte Suprema americana, examina e julga o que ela quer, o que ela entende que deva ser julgado, sem qualquer obrigação de fundamentar a rejeição do exame do recurso. Então, lá, sem dúvida, primeiro porque é uma corte suprema, nós aqui somos um tribunal da Federação, com o compromisso de dizer por último direito federal e uniformizar, não só o direito federal como também o direito constitucional, só que este não em última instância. Mas nós temos uma competência concorrente com a do Supremo. Então, em primeiro lugar, não se trata de uma corte suprema e, em segundo lugar, é um sistema constitucional completamente diferente daquele onde basta que se diga: não entendemos que essa questão é relevante, não vamos, a Corte não vai se manifestar. E não há recurso. Não há obrigação de dizer por que não vai examinar. Agora, no sistema constitucional brasileiro, o artigo 93, no inciso nove, impõe a obrigação da fundamentação das decisões judiciais. De forma que, rejeitar esse requisito de pré-admissibilidade de um recurso de revista, significa fundamentar a decisão, significa justificar porque que não é relevante sob o aspecto político-econômico, jurídico-social. Então, isto poderá acelerar ou poderá causar mais dificuldade para a prestação jurisdicional. Pelo que me parece este argumento, é decisivo; não alcançaria esse 
objetivo de atingir a celeridade. Por que? Porque já houve no âmbito do TST, tentativas de constituição de comissões com a incumbência de elaborar a regulamentação da transcendência e o que ocorreu é que essas comissões se dissolveram antes de apresentar qualquer anteprojeto para que os ministros pudessem examinar. E, quais foram as dificuldades? As dificuldades foram, precisamente: qual o órgão que vai dizer sobre esse pré-requisito de admissibilidade de recurso de revista? A SDI? As próprias turmas antes do julgamento do recurso? Então nós estaríamos colocando uma questão intermediária, intermediária não, uma questão preferencial prévia a todos os recursos. Isto exigiria, portanto, demanda de muito mais tempo, porque para dizer se é relevante ou não é relevante sobre esses quatro aspectos, nós teríamos que desenvolver considerações jurídicas, talvez até fáticas, nós teríamos uma abertura para um exercício axiológico grande, porque eu posso entender, sob o aspecto político essa questão é relevante, sob o aspecto jurídico ela é relevante o outro pode entender que não é relevante. Então, nós estaríamos a conversar e a discutir antes do conhecimento do recurso pelos requisitos legais, nós estaríamos a abrir uma discussão preliminar, que por compreender manifestações subjetivas, ao meu ver, causaria uma demora muito maior, ao invés de abreviar. Então, é um pré-requisito de natureza subjetiva que, num sistema como o nosso, repito, de fundamentação das decisões, demandaria tempo e, pela amplitude da chamada transcendência, incursões pelos mais diversos ramos do conhecimento. Então não vejo como atingir, de plano, esse objetivo com isso. Segundo lugar, acho que é incompatível um critério dessa natureza, que não tenha assento e requisitos objetivos com o nosso sistema constitucional. Nós aqui somos um tribunal da federação. Nosso compromisso é dizer por último acerca do direito federal e é uniformizar as divergências dos tribunais regionais. Hoje, com a nova lei que regula os embargos, então, só com divergência, mais se identifica essa função uniformizadora. Então, realmente, ao julgar um recurso de natureza extraordinária, já não temos o compromisso de satisfazer o interesse privado das partes. Nós temos que satisfazer o interesse maior, que é da higidez do ordenamento jurídico, a preservação do ordenamento jurídico, então, dando a interpretação acerca do direito federal. Ora, esta função que, no sistema federativo outorgou a constituição aos tribunais superiores estaria comprometida. Por que? Porque antes de examinar o direito federal, nós teríamos que saber se aquela questão tem relevância e colocaríamos um elemento subjetivo, quer dizer, preponderantemente subjetivo, à frente dos requisitos de admissibilidade do recurso que, estes sim, compromissados com o sistema federativo. Então, nós podemos examinar um recurso de revista se houver violação a lei federal ou 
Constituição da República ou se houver divergência de interpretação acerca do direito federal constitucional por parte dos Tribunais Regionais do Trabalho. Ora, evidente que se nós colocarmos antes esse requisito subjetivo, nós estamos comprometendo a nossa função primordial. Porque, por exemplo, uma questão que tem um valor econômico inexpressivo pode parecer à primeira vista que não só não apresenta interesse econômico ou social, mas será que o interesse jurídico estaria ali presente naquele caso?

José Pedro - Se a matéria for constitucional, por exemplo...

Ministra Cristina - Se a matéria for constitucional, vamos sustentar que sim. Então veja, então nós já podemos estabelecer uma premissa, então: em princípio, toda questão de fundo constitucional é relevante. Aí poderá surgir a questão, mas será que é uma questão diretamente constitucional ou indiretamente constitucional? Nós sabemos que a constituição, ela em termos de direitos sociais, ela regulamentou de forma mais ampla possível. Então, dificilmente uma questão não tem alguma conotação constitucional. Realmente, eu não vejo porque adotar um critério que é substancialmente e preferencialmente e pelo menos consideravelmente subjetivo à frente dos critérios de natureza técnico-constitucional ou à frente dos critérios legais. Quer dizer, constitucionais, comprometendo a função dos Tribunais Superiores, no sistema federativo e, legais, porque são requisitos absolutamente objetivos. Os que nós acabamos de ver, sendo que no recurso de embargos, ainda mais, porque só quando houver, realmente, divergência de interpretação entre as Turmas do Tribunal.

José Pedro - V. Exa. vê nisso alguma afronta ao devido processo legal. Esse subjetivismo sobre o que é econômico, o que é social, o que é jurídico e o que é político, poderia descaracterizar, talvez, o devido processo legal? Os outros requisitos já estão deferidos na lei, são objetivos. Não fica o advogado quando for manejar o recurso sem parâmetro legal? V. Exa. vê nisso um comprometimento do devido processo legal?

Ministra Cristina - Veja, isso é uma questão tal, aí já mais delicada e mais específica, que foge ao geral. Por que? Porque na medida em que se introduziu no artigo 896 da CLT, por força dessa medida provisória, que tem força de uma lei ordinária. Ainda que sem o processo legislativo, mas ela tem a hierarquia de uma lei ordinária e ali se diz que caberá ao tribunal regulamentar, então veja, precisaria que houvesse uma declaração de 
inconstitucionalidade desse dispositivo, até por afronta ao devido processo legal, ou seja, exorbitou-se porque, eu penso que sim.

José Pedro - Formalmente há a previsão, mas o devido processo legal é material e formal. Formalmente está prevista a relevância econômica, jurídica, social e política, mas a definição é totalmente subjetiva...

Ministra Cristina - Exatamente. Por isso acho que poderíamos até chegar a esse ponto, mas, mesmo antes de você chegar a essa consideração, pelos argumentos que eu já examinei antes, seria inconveniente manter, mas o Supremo Tribunal Federal ainda vai examinar vários fundamentos da ADIn. Um dos fundamentos da ADIn é exatamente esse. E eu penso que nós estaríamos infringindo um princípio constitucional, que é o devido processo legal ao atribuirmos o subjetivismo dos Juizes essa definição do que vai ser ou não julgado. Isso eu digo por que? Porque eu defendo o princípio da integridade do direito. Então, Ronald Dworkin, quando estabeleceu esse, é mais que uma teoria da jurisdição, o princípio da integridade, mas ela, porque ela não diz só com o Julgador, mas se nós examinarmos sob o aspecto do Julgador nos vamos ver exatamente que ela repugna o critério subjetivo e o que se sustenta, na defesa da teoria da integridade é que justamente o Juiz tem o compromisso de descobrir o direito e como é que ele vai descobrir o direito? Ele vai descobrir o direito no contexto em que se insere aquela comunidade. Então, o compromisso do Juiz no aplicar a lei é com o ordenamento jurídico, mas considerado, no contexto, e daí a pergunta que Dworkin faz, quando eu vou, claro que ele considera o sistema norte-americano, o do precedente, mas ele diz quando nós vamos aplicar um precedente nós temos que formular em que circunstância é que ele foi formulado? Quais os juizes que participaram daquela decisão? E qual o contexto normativo? Qual a comunidade em que se produziu aquele precedente? Exatamente para preservar e dar efetividade ao princípio da segurança jurídica. Então eu tenho que considerar daí a figura do juiz "Hércules", que é um juiz que teve tempo de considerar todo esse contexto para dizer: este precedente eu posso aplicar nesta situação porque foi prolatado numa situação exatamente similar a esta. Então, esse compromisso que o juiz tem em acertar, em prolatar uma decisão segura, repugna o subjetivismo. Mesmo no sistema em que foi estabelecido a teoria da integridade, que é o sistema norte-americano, que cada vez, do precedente, que cada vez mais se comunica conosco. Que nós aqui estamos cada vez mais aproveitando a teoria, o sistema da common law, hoje com a súmula vinculante e também com a aplicação dos precedentes. Então, isso é que eu digo e a teoria da integridade do Dworkin exatamente se 
contrapõe à teoria universalista que predomina na Alemanha, que é defendida, que tem como grande doutrinador o Roberto Alexy. Por que? Porque a Corte constitucional alemã, a quem o Alexy dá respaldo doutrinário, ela tem assumido uma postura política, preservando, até, o poder legislativo de editar uma lei, porque a Corte Suprema, ela assume até esse desgaste político de criar direito. Criar direito na interpretação, afirmar o direito positivo. A flexibilidade em termos de decisões da, porque é uma pauta política que a Corte constitucional alemã assumiu, de criar o direito. E justamente, que nós aqui, que tem servido, inclusive, para o Supremo Tribunal Federal, de parâmetro. Veja que o Supremo Tribunal Federal cria direito em muitos casos, vou dar um exemplo: no caso da greve do servidor público criaram direito, ou seja, mandaram aplicar a lei geral naquilo que fosse compatível, mas em mandado de injunção. E o mandado de injunção, pela constituição, até permite nesse caso essa criação legislativa, mas no caso da fidelidade partidária, estabeleceu que o mandato é do partido e não do candidato. Deixe-me lembrar de uma situação... no caso das algemas. Na própria lei da bio-segurança, a corrente vencida, estabelecia uma série de critérios, estabelecia até um criação - da corrente vencida - de órgãos que exercessem a fiscalização, no caso da demarcação da raposa do sol foram estabelecidos critérios; essa é uma pauta que a Corte Constitucional alemã vem realizando, ou seja, no âmbito da jurisdição se compreende esse poder de legislar, em concreto. Isso compromete, eu acho, o princípio da segurança jurídica e é exatamente esses critérios subjetivos, eles são possíveis de serem exercitados nessa concepção flexível, digamos, do ordenamento jurídico. Mas, num sistema como o nosso não cabe ao Juiz decidir. Veja que hoje existe uma tendência, um outro exemplo que eu dou, no âmbito de todos os tribunais da Federação. Regionais, superiores, fixação do dano moral, qual é o critério que existe, a não ser o subjetivo? Então, há uma tendência de os juizes decidirem e, depois que o juiz descobriu que ele pode decidir com base nos princípios, então, ele cria direito. Então, essa criação do direito que seria a mais ampla possível no sistema da transcendência é que me preocupa. Porque, não só, compromete a segurança jurídica, compromete o devido processo legal e compromete a celeridade, que é a finalidade que justificou a ( ) essa normatividade. Isso é o que eu acho.

José Pedro - Ministra, para finalizar, V. Exa. acha que o TST vai disciplinar ou vai rejeitar ou, ainda, vai propor uma terceira solução para a transcendência?

Ministra Cristina - Esta comissão que foi formada, ela tem cinco membros, dos cinco membros, três membros olham com muita reserva a transcendência, dois acham que deve 
ser regulamentada, estes dois estão elaborando uma minuta, que nós vamos examinar, mas eu penso que, como essa comissão não foi criada para regulamentar, foi para estudar a regulamentação, acho que cabe no âmbito dessa comissão e nós estamos preocupados em estudar também, outras alternativas que possam amanhã serem colocadas como ante projeto de lei. Vou lhe dar aqui alguns exemplos, por exemplo, para promover celeridade, que é o objetivo de todos, só permitir recurso de revista quando estiver uniformizada, uma idéia, no âmbito de cada Tribunal Regional a jurisprudência. Ao invés de recurso de revista para que o TST uniformize divergências internas de Tribunais Regionais, só admitir a revista quando depois de uniformizada no âmbito de cada Tribunal Regional. Tem dificuldades, pois tem questões múltiplas que muitas vezes estão ali sendo discutidas, não é um tema só. É uma idéia, que, dentro do Tribunal, nem é de minha autoria, mas que eu já sei que foi pensada. Enfim, outras modalidades que não sejam tão subjetivas como essa e que não comprometam, não é verdade, esse compromisso que o Juiz tem de observar o ordenamento jurídico na sua integridade sem deixar que o Juiz se transforme no senhor do processo e no senhor do recurso. É muito perigoso isso porque compromete a segurança jurídica, compromete a democracia e a advocacia; o estado de direito exige segurança jurídica ...

José Pedro - O que Norberto Bobbio mencionava como a definição das regras do jogo. Elas hão se ser claras....

Ministra Cristina - Tem que estar muito claras; não se podem atribuir esses poderes a quem quer que seja, de decidir o que é direito sem o respaldo do ordenamento jurídico. Isso é o que me parece.

José Pedro - Muito obrigado, Ministra.

\section{MINISTRO RENATO LACERDA PAIVA}

José Pedro - Ministro Renato Lacerda Paiva, agradeço a colaboração com a minha tentativa de estudar a transcendência e, respeitosamente, porque V. Exa. participou da antiga comissão, tomo a liberdade de pedir a sua opinião, bem pontual, bem prática, como lhe é peculiar, sobre a transcendência. 
Ministro Renato Lacerda Paiva - José Pedro, é um grande prazer expor as minhas idéias, até porque venho estudando essa questão da transcendência, desde o início, e, confesso, até com boa vontade. Realmente, participei da última comissão à qual renunciei por razões de convicção, de foro íntimo, e em decorrência da dificuldade de conseguir montar um sistema que venha a beneficiar a prestação jurisdicional do TST. Como já havíamos conversado antes, primeiro, por questão de ordem prática, porque nós temos 4 tipos de transcendência (política, econômica, social e jurídica). Então, por exemplo, num recurso com dez temas, teríamos que discutir a transcendência em cada matéria, em cada tema, e, com certeza, poderia haver divergência interna entre os Ministros, em cada um deles . Além disso, o advogado tem direito de sustentar, em cada um dos temas.

José Pedro - E a parte adversa contrariar...

Ministro Renato Lacerda Paiva - De fato, também contrarrazoar, não é verdade? A outra dificuldade é que a lei determina que o exame da transcendência seja fundamentado. Aliás, isso até parte de um princípio de que essa regulamentação devia ter critérios objetivos, porque fundamentar algo subjetivo também é difícil, não é? E, para se criarem esses critérios objetivos, porque não podemos cair na subjetividade pura e simples, encontramos dificuldades muito grandes. Então, a primeira delas é conceituar o que é relevância econômica, política, jurídica e social. Você poderia até dizer assim: bom, têm relevância social, p. ex., as ações de instrução processual de sindicato, ações civis públicas, ações que envolvam direitos coletivos, latu sensu e assim por diante. Poderia dizer que têm transcendência jurídica, por exemplo, as decisões que sejam contrárias à nossa jurisprudência. Poderia dizer que têm transcendência política aquelas matérias novas, que dependem da uniformização da jurisprudência. Já a econômica, seria um pouco mais delicado, de pendendo do ponto de vista da parte, se reclamante, se reclamado, se empresa x ou y. Você poderia até dizer, por exemplo, que a transcendência econômica seria aquela que envolvesse o risco do perecimento da empresa, critério que hoje sabemos deve ser considerado na prestação jurisdicional, sempre tomando cuidado de não só tutelar o empregado, mas, também, de preservar o emprego, que é o bem maior. Outra questão, a transcendência social poderia ser reconhecida toda vez que envolvesse higiene, segurança e medicina do trabalho, acidente do trabalho, dano moral, etc. Em síntese, até seria possível tentar estabelecer critérios objetivos, embora com algumas dificuldades, até porque esses critérios, eles não alcançam todas as situações. Então, se nós temos que regulamentar, nós teríamos que regulamentar de forma objetiva e exaurindo os temas. Não podemos deixar 
isso em aberto, pois cairíamos naquela situação que dissemos há pouco. Em cada tema teríamos de fazer a discussão e seria interminável. Há alguns temas que dificultam essa conceituação da transcendência, como a negativa de prestação jurisdicional. Se você sustentar que tem transcendência, estará ligada à própria validade dessa decisão, da atuação jurisdicional. Todavia, aí o que vai acontecer? Todos os recursos virão por negativa de prestação jurisdicional, até provocar a transcendência. Matéria constitucional, como é que nós vamos dizer que não há transcendência em matéria constitucional? É muito difícil. Se dissermos que há transcendência toda vez que houver matéria constitucional, todos os recursos virão com invocação de matéria constitucional. Mais à frente, a questão final também dos agravos de instrumentos.

José Pedro - O que é importantíssimo também.

Ministro Renato Lacerda Paiva - Veja bem, nós sabemos que os agravos são examinados a partir dos pressupostos extrínsecos e também dos pressupostos intrínsecos. E o critério de transcendência, ele é antecedente ao exame dos pressupostos intrínsecos, no recurso de revista e obviamente o será no agravo também. Então, o que acontecerá é que no agravo nós vamos ter que examinar também todos os tipos de transcendência em cada tema.

José Pedro - A transcendência, porém, só está prevista para o recurso de revista e, não, para o próprio agravo, podendo haver situações contraditórias e embaraçosas...

Ministro Renato Lacerda Paiva - Exatamente. A menos que se estabelecesse que só examinaríamos transcendência no recurso de revista. Também seria uma saída, mas para isso teríamos que inverter a ordem de exame. Quando nós examinarmos os pressupostos intrínsecos entendermos que é possível conhecer do agravo, daí nós passamos direto para a revista. Mas pode acontecer uma situação muito interessante, de nós provermos o agravo para o exame do recurso de revista e no recurso de revista você dizer que não há transcendência. E, nesse e em inúmeros casos, teria ocorrido uma enorme perda de energia e de precioso tempo. Então, a grande dificuldade da regulamentação da transcendência é criar um sistema que seja coerente e que permita efetivamente facilitar nosso trabalho. Agora, o último tema que eu tinha mencionado é a questão da utilidade. Então, até aqui, tratamos do mecanismo e da operacionalidade do sistema. Ora, a utilidade é fundamental, pois o objetivo da transcendência é concentrar a energia naquilo que é importante para agilizar e construir a jurisprudência para todo o território nacional. Mas, se não houver a 
Súmula Vinculante, nada impedirá que os Tribunais continuem a julgar contra nossa jurisprudência e os recursos subirão do mesmo jeito. Então, são essas as dificuldades que eu vejo e, na minha limitação intelectual, não consegui superar.

José Pedro - Muito obrigado.

\section{MINISTRO LÉLIO BENTES CORRÊA}

José Pedro - Ministro Lélio Bentes Corrêa, muito obrigado pela acolhida deste estudante. Nosso tema é a "Transcendência". V. Exa. participa da comissão e gostaria de saber sua opinião, seja sobre a própria existência da transcendência, sua viabilidade, seja como se estabeleceriam novos critérios para os recursos de natureza extraordinária, aqui no TST.

Ministro Lélio - Não há dúvida que o volume de processos que nós enfrentamos no Tribunal Superior do Trabalho, aproximadamente, 140 a 170.000 por ano, importam uma carga de trabalho sobre-humana. O que não nos autoriza, no entanto, a "desumanizar" o processo de entrega da prestação jurisdicional. Ou seja, nós não podemos encarar o processo como adversário. Não podemos encarar nossa missão como missão de exterminar processos. Diante de uma situação como essa, é natural que surjam preocupações em encontrar formas de filtrar melhor os processos que chegam à instância superior. Até com o objetivo de permitir um estudo adequado e o debate, em profundidade, das questões verdadeiramente relevantes, que precisam ser dirimidas aqui na instância extraordinária, mas perde-se de vista a origem de todo esse processo. O problema não está só nesse extremo aqui da ponta, o TST. Está na outra extremidade, no índice de litigância, que é altíssimo no Brasil. Poder-se-ia dizer até que, existe uma cultura nutrida da seguinte maneira: o empregador não paga porque não sofre a fiscalização necessária por parte do Estado. Outros, ainda, de uma forma ainda mais dramática para a dignidade do trabalhador não pagam porque obtêm lucro na demora do trâmite processual. E o empregado, a seu turno, sabedor de que o empregador já está imbuído dessa cultura de sonegar direitos, ajuíza reclamação imediatamente, quase, após à rescisão do contrato de trabalho. Tratamos um círculo vicioso que se retro-alimenta e que enseja esse fenômeno absurdo de ajuizamento de 2.000.000 de ações por ano. Então, resolver o problema da Justiça do Trabalho, pressupõe resolver o problema das relações do trabalho no Brasil. Devolvê-las ao patamar de observância da legalidade, de respeito aos direitos fundamentais, mas para 
isso é necessário mudar uma cultura. Enquanto essa solução não vem e você mesmo menciona, com muita propriedade, uma das ferramentas fundamentais nesse processo seria a criação de mecanismos eficazes e confiáveis de conciliação extrajudicial, não é a realidade que estamos presenciando hoje, em que, caso recente julgado pelo TST, se verifica que certas comissões de conciliação cobram $20 \%$ do empregado no caso de sucesso da conciliação e $20 \%$ da empresa, no caso de fracasso, ou seja, o pagamento da comissão está garantido, direito nem sempre. Essa solução, então passa pela criação desses mecanismos, que a essa altura pressupõe uma reformulação estrutural da vida sindical brasileira, para que os sindicatos possam resgatar uma legitimidade perdida há muito tempo. O Brasil tem hoje, segundo dados oficiais do Ministério do Trabalho, após o recadastramento, 12.900 sindicatos. Muitos deles, não fazendo absolutamente nada, senão receber o imposto sindical e celebrar convenções coletivas altamente deletérias aos interesses dos trabalhadores. Como incumbir a esses sindicatos - não me refiro àqueles sindicatos sérios, mas esses sindicatos de fachadas, sindicatos, alguns frágeis na representação dos interesses dos trabalhadores -, a missão de supervisionar uma conciliação extrajudicial, minimamente séria. Mas enquanto essa solução extrajudicial não se oferece, então nós, incapazes de atacar a causa, tentamos lutar contra as consequências. E me parece essencial, ao refletir sobre a criação de eventuais filtros que possam diminuir o volume de processos a chegar na instância extraordinária, nós renunciarmos à tentação de estabelecer mecanismos que deixem na mão do Julgador, com todo o grau de subjetividade, a oportunidade de decidir o que vai julgar ou não. Isso, a meu juízo, seria extremamente prejudicial, não só à imagem, mas à própria função da Justiça do Trabalho, que perderia credibilidade rapidamente. Todo o esforço de pessoas que investiram na construção de uma Justiça do Trabalho identificada com a sociedade, reconhecida pela sociedade, iria por água abaixo se a partir de um determinado momento, nós, sem indicarmos com clareza um critério objetivo, passássemos, subjetivamente, a cada um, de per si, definir o que vem a ser relevante o que não é relevante, em termos de uniformização da jurisprudência. De forma que, com esses pressupostos, me parece, embora compreenda a preocupação daqueles que advogam a necessidade da transcendência, mas, me parece uma empreitada altamente delicada a tentativa de regulamentá-la. As idéias até aqui colocadas, por alguns colegas que, a exemplo de outros tribunais, propõem critérios de relevância econômica, relevância jurídica, relevância política, essa idéia, em princípio, me parece difícil de concretizar, justamente porque não consigo encontrar uma regra objetiva, democrática e transparente, que desse concretude a esses critérios. Afinal, qual seria o 
valor econômico necessário a justificar o pronunciamento pelo Tribunal Superior do Trabalho, seria o caso de nos tornarmos uma justiça só dos altos empregados, então? Aqueles que têm causas com valores significativos? E deixarmos de lado os empregados domésticos? Os trabalhadores rurais? As vítimas de trabalho escravo? De trabalho infantil?

José Pedro - Interessante a lembrança do trabalhador doméstico porque recentemente o TST consolidou jurisprudência, em nome do princípio da igualdade, que os direitos são iguais, por exemplo na questão das férias. Recentemente cuidou da empregada doméstica gestante. Fundamental, portanto, essa atuação do TST, para que não se torne tribunal para uma elite de trabalhadores, o que seria uma distorção terrível.

Ministro Lélio - Total. Seria a negação da razão do ser da Justiça do Trabalho. Além disso, e a experiência da comissão que já se reuniu anteriormente, me parece levar ou justificar essa conclusão; as exceções seriam tantas que praticamente não haveria um critério. Haveria mais exceções do que regra. Uma das propostas que também ouvi, seria no sentido de reconhecer ou de procurar estabelecer um critério diferenciado quanto ao reconhecimento da relevância dos recursos interpostos pelo empregado e dos recursos interpostos pelo empregador. Agora, imagine você, uma ação que se discute, por exemplo, um enquadramento de um gerente na exceção do inciso segundo do artigo 62 da CLT, se é o empregado que recorre afirmando que não está enquadrado no dispositivo, o recurso tem relevância. Se é o empregador que recorre para que se diga que o empregado está enquadrado no dispositivo não tem relevância. E a isonomia, aonde fica? Então, esse critério que eu chamaria de critério da definição, o critério positivo de definição de transcendência, me parece, em princípio, fadado ao insucesso. O que se poderia imaginar, talvez como uma alternativa, até para que se possa verificar como o instrumento poderia funcionar, seria a concepção de um critério negativo de transcendência. Ao invés de se procurar afirmar o que é transcendente, afirmar-se aquilo que não tem transcendência, que não tem relevância para fins de uniformização da jurisprudência. E, de pronto, eu diria, que não tem relevância para nossa atividade uniformizadora, situações que nós já uniformizamos. Então, as decisões lastreadas em súmula ou orientações jurisprudenciais do Tribunal Superior do Trabalho não estão sujeitas à revisão do Tribunal Superior do Trabalho. Porque esse, e eu imagino José Pedro que você na sua longa experiência aqui de Tribunal, tenha também se defrontado com isso. Esse é o nosso dia-a-dia, o nosso dia-adia, praticamente $90 \%$ dos casos, é dizer que o Tribunal decidiu bem, de acordo com a súmula tal ou orientação jurisprudencial número X. Poder-se-ia imaginar um critério de 
transcendência por aí, talvez, talvez. Mas, claro, haveria a necessidade de se criarem salvaguardas. As nossas OJ's não são eternas. O Supremo tem demonstrado isso. Precisaríamos então criar mecanismos de constante atualização e revisão da nossa jurisprudência. Mas, talvez, talvez, esse caminho pudesse ser visualizado como uma tentativa de regulamentar o dispositivo que foi inserido na Consolidação das Leis do Trabalho. Se de um lado há essa dificuldade quanto a possíveis evoluções da jurisprudência, de outro há a vantagem de se ter o critério claro, objetivo, transparente e ao qual os advogados que militam na Justiça do Trabalho já estão acostumados. E qual seria a diferença? Nós já temos o artigo 896 da CLT, parágrafo quinto, que impede a subida dos recursos. Impede em termos porque há possibilidade de interposição do agravo de instrumento. As decisões do TST, em matéria de transcendência não seriam agraváveis,. E segundo, porque poder-se-ia imaginar um formato qualquer que fosse consensual aos Ministros, que facilitasse o exame desses casos. Ao invés de expender toda a fundamentação, a começar com ementa, relatório, talvez se pudesse adotar um formato simplificado, como a lei consagrou, por exemplo, no caso do rito sumaríssimo. Mas, ainda assim, no meu entender, essa proposta, ela, se viesse a ser lançada em caráter experimental, deveria, de início, se restringir aos agravos de instrumentos. Considerando que os agravos de instrumento não comportam sustentação oral e assim não haveria prejuízo algum às partes, no não reconhecimento da transcendência por essa forma nova de examinar o fluxo. E esse termo da sustentação oral é outra dificuldade que se oferece a partir do texto legal consagrado. Porque ali se estabelece a obrigatoriedade, não é, de decisão fundamentada, preservado o direito à sustentação oral. Ora, se nós tivermos uma sustentação oral para cada processo que formos julgar sob a ótica da transcendência, nós estamos duplicando os atos processuais. E o objetivo de celeridade fica comprometido. O que também me fez sustentar na comissão o entendimento de que, ainda que consigamos chegar a um consenso, quanto à regulamentação da transcendência, nós precisaremos também trabalhar numa reformulação legislativa e, aí, ao fazê-lo, porque não, porque não encarar a questão da uniformização de uma forma mais abrangente e aí me adianto um pouco ao que, seguramente, você irá falar com o Luiz Phillipe, que é o autor dessas reflexões que vou rapidamente mencionar. O problema que nós enfrentamos aqui é a falta de uniformidade dos pronunciamentos da Justiça do Trabalho, especialmente no segundo grau.

José Pedro - Não há uma uniformização interna na jurisprudência dos regionais. É isso?

Ministro Lélio - É isso, é essencialmente isso. 
José Pedro - De fato, ninguém se lembra da obrigatoriedade de uniformização da jurisprudência interna dos Regionais, prevista no $\S 3^{\circ}$ do art. 896 da CLT, introduzido pela Lei 9756/98.

Ministro Lélio - Se a primeira turma do seu tribunal, recebe um processo de um empregado contra determinada empresa, tratando de horas extras e reconhece o direito. E a segunda turma, num caso idêntico, de um outro empregado, contra a mesma empresa, não reconhece o direito às horas extras, o que vai acontecer é que nós vamos ter recurso nos dois processos. Porque ninguém se conforma com isso e não pode se conformar mesmo. É o mesmo tribunal. Mas em certos casos, a mesma turma, por uma variação de quorum eventual, uma convocação, muda o julgamento, muda o entendimento. E tudo isso vai parar aonde? No TST.

José Pedro - Outro ponto sensível, diria, é que os Regionais, em geral e, até, por razões ponderáveis, não se submetem à jurisprudência do TST ...

Ministro Lélio - É verdade.

José Pedro - E a súmula vinculante de tribunal superior, ajudaria?

Ministro Lélio - Por convicção penso que a súmula vinculante traz mais dificuldades do que soluções. Tenho absoluta certeza de que a uniformidade da jurisprudência se alcança pelo convencimento e não pela imposição. Você, seguramente, aplicará a nossa jurisprudência, primeiro, por se convencer que ela está correta. Segundo, por estar consciente de que o poder judiciário é orgânico. O que hoje nós temos é um desarranjo na nossa instituição, porque parte da magistratura se comporta como se fora um feudo, impermeável, venham de onde vierem, seja de um juiz de primeiro grau seja do tribunal superior: "o meu pensamento é o correto", sem se dar conta das repercussões que isso traz para o sistema e para o jurisdicionado, que muitas vezes se vê aí aguardando o pronunciamento de uma corte superior por três, quatro anos, quando a questão, absolutamente pacificada, poderia ter sido resolvida; cria-se uma ilusão, que é até, eu diria. Desumana. E se eu te disser a quantidade de processo que nós temos aqui que se discute correção monetária é inacreditável? Agora, essa atitude, ela começa a mudar, já aqui no nosso tribunal. É cada vez mais frequente nós encontramos acórdãos, e eu mesmo tenho me posicionado nesse sentido, acórdãos em que se defende todo um ponto de vista e se conclui, porém, o destino dessa matéria está selado pelos pronunciamentos reiterados da 
corte, no sentido de que com essa fundamentação e, eu digo a expressão, como é? É disciplina judiciária. Não. Mas em respeito ao caráter uniformizador da jurisprudência, reconhecido às funções deste tribunal, aplico ao caso concreto...

José Pedro - É a aceitação da função do Tribunal Superior, que é a uniformização da jurisprudência,

Ministro Lélio - A nossa função é essa; nós não fomos criados para reformar decisões de tribunais regionais; nós não perseguimos os tribunais regionais; nós não somos adversários de juizes de tribunais regionais, ao contrário. Nós somos é iluminados pela instâncias já percorridas, que nos trazem novas idéias e nos permitem avançar na nossa jurisprudência. Mas, uma vez definido o estágio em que se encontra a jurisprudência, seria muito interessante que os tribunais regionais tomassem uma postura prática em relação a isso, mas ainda assim, ainda que soframos essas consequências de decisões que não aplicam o nosso entendimento mesmo sumulado, não acredito que seria uma solução adequada a adoção de súmula vinculante. A súmula vinculante tem um aspecto que me seduz, que é a vinculação da administração pública, na condição de parte, para que o INSS, por exemplo, pare de recorrer por causa $\mathrm{R} \$ 30,00$, como nós temos verificado aqui. Para que a Fazenda Pública não recorra mais contra o pagamento dos dias trabalhados em relação ao contrato nulo. Ou seja, matérias que não precisavam mais subir. Agora, vincular o Juiz me parece filosoficamente, contrário à essência da magistratura. A independência é essencial à magistratura. Assim como é a organicidade, mas essa organicidade só se alcança por convencimento. Por exemplo, nós temos que mostrar à magistratura brasileira que nós estamos coesos, sensíveis àquilo que vem dos tribunais regionais e dos juizes de primeiro grau e que estamos trilhando um caminho razoável. Eu acho que, com esses elementos, a grande maioria dos juizes tenderia a aplicar com mais frequência os nossos entendimentos.

José Pedro - Para finalizar Ministro, V. Exa acredita que para o ano que vem (2010), quem sabe, teremos alguma novidade sobre a transcendência?

Ministro Lélio - É possível, é possível. É, claro, que os debates são muitos e acalorados em torno do assunto. A própria comissão tem debatido em alto nível, mas os entendimentos são bastantes divergentes e é bom que o sejam, para que nós possamos experimentar todas as hipóteses antes de tomarmos uma decisão final. Eu até propugno na comissão que qualquer solução que se adote seja, necessariamente, unânime, pois se não 
conseguirmos a unidade entre cinco, como vamos conseguir entre 27. É impossível. Mas eu tenho conversado com vários colegas e tenho percebido que essa noção de uma transcendência negativa ou de um critério negativo de transcendência, ausência de transcendência, tem tido uma razoável acolhida. Porque é como eu já disse, porque nós não estaríamos trabalhando com o desconhecido, estaríamos trabalhando com aquilo que nós conhecemos. E com uma vantagem, também, talvez esse fosse um caminho alternativo ao 557 do Código de Processo Civil que causa tanta polêmica aqui no tribunal. O 557, pelo seu aspecto muito abrangente, ele, de certa forma, permite que cada Ministro tenha a sua transcendência.

José Pedro - Bem lembrado. Seria uma transcendência branca, como a gente ouve falar.

Ministro Lélio - E é isso que nós temos que evitar a qualquer custo. Nós precisamos manter, acabei de dizer, mas, queremos cobrar sentimento de organicidade à magistratura do segundo e primeiro graus, por isso nós temos que demonstrar coesão aqui também. Nós não podemos exigir deles uma coisa e aqui nos comportarmos de outra maneira. Então, por isso até, eu imagino que existe, sim, uma possibilidade nós termos algum critério adotado em caráter experimental e, ao mesmo tempo, um projeto de lei mais abrangente, contemplando esse aspecto da uniformização nos tribunais regionais, da possibilidade de indeferimento de recurso no primeiro grau. Afinal de contas, tem matéria que por mais que se preze o princípio do duplo grau de jurisdição...

José Pedro - existem varias matérias totalmente sedimentadas na jurisprudência que não faz sentido recurso algum. E, se me permite Ministro, haveria caminhos muito mais simples para coibir a recorribilidade exagerada, como, por exemplo, aumentar o dissídio de alçada de dois salários mínimos para cinco, o teto do sumaríssimo e o depósito recursal nestes processos.

Ministro Lélio - Sim, sem dúvida.

José Pedro - Um “mix" de várias coisas, não só uma coisa dirigida contra a recorribilidade específica, mas um conjunto de idéias. Por exemplo, há OJ's já antigas, que até deveriam ter sido já transformadas em súmulas, e que, por força da lei, impediriam a revista no sumaríssimo... 
Ministro Lélio - Correto. Você tem razão, esse é um efeito colateral das OJ's porque elas, de certa forma, nos acomodam, É uma criação estranha à própria tradição do poder judiciário, que sempre organizou...

José Pedro - ...é uma simplificação da Súmula 333...

Ministro Lélio - ... pronto. O objetivo da OJ quando foi introduzida era exatamente facilitar a aplicação da Súmula 333, só que ao invés de invocar os precedentes e aplicar a Súmula 333, alguém achou mais simples citar o número da OJ. E, isso se alastrou de uma tal maneira; é isso que eu quis dizer no começo, de nós resistirmos à tentação de encontrar a solução para o nosso problema, às vezes, criando outros problemas. Nós temos que pensar na solução da conflituosidade na Justiça do trabalho. Nós não podemos nunca perder isso de vista. Então, qualquer solução que se encontre, nesse momento, de forma a permitir um trabalho mais razoável para o Tribunal Superior, insisto, não é com o objetivo de os Ministros ficarem flanando, porque você sabe bem que isso nunca vai acontecer, nosso volume de trabalho permite aí uma jornada de 12 horas, com tranquilidade, qualquer que seja o volume de processo, mas, de pelo menos permitir um estudo mais detido de cada caso, um debate realmente profundo. É extremamente frustrante, você participou de inúmeras sessões aqui no tribunal, aquela necessidade que nós temos, às vezes, de ouvir a opinião dos colegas, de contrapor, nossas idéias até para formarmos uma convicção sólida sobre o assunto, e tudo isso fica contingenciado em razão do tempo.

José Pedro - é quando a construção da jurisprudência fica mais sujeita ao argumento de autoridade, talvez do mais antigo, do que em razão de uma convicção demonstrada...

Ministro Lélio - É, acontece, acontece. Isso também acontece.

José Pedro - Muitíssimo obrigado, Ministro.

\section{MINISTRO PEDRO PAULO TEIXEIRA MANUS}

José Pedro - Ministro Pedro Paulo Manus, agradeço a deferência da acolhida deste seu aluno, que está tentando escrever alguma coisa sobre a transcendência. Afinal, Ministro, com sua prática de magistrado, desde o primeiro grau, na condição de professor emérito da PUC de SP, como vê V. Exa. a questão da transcendência? 
Ministro Pedro Manus - Bom, a primeira consideração é que eu acho muito oportuna, interessante a sua idéia de fazer um estudo acadêmico, científico sobre esse assunto que, eu ia dizer, atormenta a todos nós, mas não é bem o termo, preocupa todos nós. Bom, são duas questões, a meu ver, distintas. Uma delas é o projeto que foi rejeitado, depois a Medida Provisória que inseriu o 896-A e, então, a origem, e agora a regulamentação desse artigo de lei, oriundo de uma Medida Provisória, que sequer apreciada pelo Congresso foi, esse é um aspecto. Outro aspecto, que me parece que é esse que está interessando aqui, é com relação à transcendência como forma de contribuir para que se agilize a prestação jurisdicional. $\mathrm{O}$ nome ficou estigmatizado, exatamente por causa da origem. Nós temos, atualmente, uma comissão no TST, a estudar se é o caso de propor ou não uma regulamentação. Uma tarefa que voltará ao tribunal pleno para apreciar eventuais conclusões dessa comissão. Eu vejo uma preocupação maior ainda porque o nosso tipo de processo, você sabe tão bem quanto eu, senão melhor, ele é muito variado em questão de temas. É diferente um processo no Supremo ou no STJ, que versa um tema só e que um ou outro Tribunal pode dizer que: “Olha, há relevância nessa matéria ou não há.” O nosso processo quando tem pouco, tem três ou quatro temas. Um pode ser relevante ou transcendente, como a gente chamar, e outro, não, ou outros, não. Isto não resolverá o processo. Bem, a par dos ajustes necessários, se amanhã nós tivermos a implantação, a regulamentação da transcendência, a quem caberá funcionalmente deliberar? O Relator? caberá agravo para turma. A turma? caberá embargos para a SDI. A uma turma especial que, encontrando a transcendência, determinará a distribuição daquele recurso para outras turmas? Enfim, são várias as hipóteses. Mas a minha maior preocupação é a seguinte: se a intenção da transcendência é agilizar julgamentos, eu, de início, tenho sérias dúvidas se agiliza ou, não. Segundo, quais critérios nós vamos utilizar para dizer se há transcendência econômica, jurídica, social, política. Esses critérios, se formos 24 Ministros a examinar, serão unívocos ou equívocos?. Agora, eu estou levantando os problemas, exatamente, porque é um tema que nós não temos sequer uma pista para regulamentar, mas não estou dizendo que nós não devamos regulamentar. Eu acho que estou mais aflito do que outra coisa, com esse volume de processos incrível. A coisa, acabei de examinar aí agravos em despacho em agravo de instrumento, é impressionante, um determinado escritório tem 6 agravos que são repetição do agravo que foi trancado por despacho, que por sua vez, foi rejeitado na origem, e assim por despacho, que reproduzia a revista, quer dizer que é nítida a intenção de apenas de protelar. Então, o sistema processual nosso é insatisfatório. Alguma coisa nós precisamos fazer para mudar o eixo da recorribilidade para que esse trabalho seja profícuo. O que eu 
chamo de profícuo? que a gente possa analisar cada processo com cuidado que merece num tempo razoável. Hoje, você sabe melhor do que eu, nós estamos nessa encruzilhada, ou julga tudo rápido, muito mal julgado ou julga devagar, muito bem julgado. E aí nós temos variações sobre esses dois extremos. Então, eu me considero no meio, porque não julgo quanto outros, mas não tão devagar quanto outros. Então, a qualidade dos meus serviços não é tão ruim nem tão boa. Evidentemente, seja qual for a estrada escolhida, estamos todos insatisfeitos: quem julga, quem faz o serviço de preparação de julgamento, os advogados, os destinatários. O que não tem cabimento, o Tribunal está em vias de bater o recorde, em 2009, do número de julgamentos de recurso do ano passado, mais de 240.000 processos, tem cabimento? Mais de 20.000 processos por mês, imaginando doze meses, mas são dez, quer dizer, mais de 25.000 processos por mês. Então, voltemos ao começo da conversa. Eu acho que é preciso encontrar um modo de permitir que se recorra ao TST, mas estabelecendo o espírito que a legislação pretendia. Quando se tratar de matéria relevante de direito, a questão vem ao TST. Você vai dizer, mas não é assim, o artigo 896 não tem só a letra A, B e C, as divergências. Tá bom. O Presidente do TRT tranca a revista, vem o agravo para cá, o que a parte pretendia é que a sentença não produzisse efeito desde logo e já conseguiu. Ah, mas então, dá só efeito suspensivo à revista e ele executa provisoriamente. Ele entra com uma cautelar aqui para dar efeito suspensivo, até na rescisória isso virou 'carne de vaca', que dirá no conhecimento.. Até com o trânsito em julgado. Então, eu acho que a preocupação com a transcendência ou com o nome que venha a ter no futuro, é fundamental. Eu vou fazer um parêntese: eu não acho que com regra processual a gente consiga resolver o problema. Quer dizer, dentro do Judiciário nós podemos minimizar o volume de recursos, mas o que eu acho é que, primeiro essa litigiosidade precisava ser contida extrajudicialmente. Segundo, era preciso que nós tivéssemos instâncias extrajudiciais seguras, para que os problemas fossem resolvidos. Questões que são aritméticas ou matemáticas não têm que vir aqui. Quer dizer, precisaríamos ter ou comissão de conciliação prévia ou conselho de arbitragem seguros, que permitissem as pessoas resolverem esses problemas. Aí nós temos uma história formidável, tem um quitação extrajudicial, mas é um quitação que não quita. Porque quita o que está expressamente discriminado e o restante não; então não serve para o fim que se propõe. Nós estamos enxugando gelo, então. Eu acho que precisa, eu até arriscaria dizer o seguinte é muito difícil que o Tribunal regulamente a transcendência porque o vício de origem ficou muito marcado. Mas quem sabe se essa comissão que existe não acende uma luz dizendo: olha, nós entendemos que deve haver um projeto de lei, com tramitação 
preferencial, que estabeleça critérios para evitar, por exemplo, o excesso de agravos. Eu sei que no Congresso tem um projeto, até um advogado de São Paulo, advogado não, desculpa, um deputado de São Paulo que parece que é o relator, que pretende estabelecer depósito prévio também no agravo de instrumento. Como é uma regra para diminuir recurso, para dificultar, vai haver uma (grita) geral, possivelmente que é por isso que não passou ainda, não sei se está na comissão ou no plenário. Mas eu vejo com bons olhos porque o próprio Tribunal, nós nossos culpados, na formação da jurisprudência, a gente tem um cuidado danado em não cercear, na dúvida, deixa recorrer. E nós, com isso, vamos estimulando os recursos. É sintomático. Olha só, não cabe mais embargos da Turma para a SDI quando há ofensa à lei. Muito bem, teria que ir pro Supremo direto. Como não é matéria constitucional, a SDI2 teve um aumento no número de rescisórias.

José Pedro - O acréscimo das rescisórias está ocorrendo porque o legislador ignorou que pudesse ocorrer eventual falta de fundamentação, vício de julgamento na Turma, e, ainda assim, não vai ter violação do 93, IX...

Ministro Pedro Manus - Não.

José Pedro - Isso é terrível. Porque, sendo uma questão comum, pode haver falha, mesmo, de julgamento.

Ministro Pedro Manus - É. Não parece um cachorro querendo morder o rabo? Porque é o seguinte, a gente acaba raciocinando como se as decisões daqui mereçam ser reformadas ou alteradas, seja a maioria. E por que são a maioria, precisa garantir recurso, mas na verdade precisa garantir recurso, porque o volume de processos é tamanho que a qualidade diminui e a quantidade de erros aumenta. Aí o cachorro correndo atrás do rabo dele para morder. Se você brecar na origem, certo, o volume de processos é razoável, não há dúvida, a qualidade das decisões melhora. A recorribilidade diminui. Sujeito tem uma decisão desfavorável, mas ele não tem como recorrer. Hoje é fácil o camarada pegar uma "peninha", em qualquer decisão e vir discutir. Criou-se uma cultura, isso anos e anos, em que a regra é recorrer. Quem em sã consciente pega uma decisão desfavorável e diz: "É, eu perdi, mas o Juiz está certo, eu vou cumprir". Se fizer isso é louco, perde o emprego, perde cliente, é mandado embora do sindicato, da empresa, enfim. Sem contar que o Estado é o maior culpado por essa situação. Dos vinte maiores reclamados do TST, 16 são do poder público Federal, Estadual, Municipal. Pega a estatística do TST, tem lá quatro bancos 
privados, conversa com qualquer advogado de banco ele vai dizer: 'o nosso banco tem 20.000 processos, 18.000 do banco estatal que nós incorporamos,' puros, de origem como eles gostam de dizer - nos temos 2.000, somos recorrentes ou recorridos comuns. Então, quem atravanca? Somos nós mesmos, o Estado.

José Pedro - E o próprio Estado depois, cumpre a decisão por precatório, tem os juros de mora diminuídos etc. Ministro, para finalizar, V. Exa. acredita que, se não vier a ser regulamentada a transcendência, algum projeto de lei pudesse, talvez, sair? É essa a sua perspectiva?

Ministro Pedro Manus - É. Eu mais espero do que acredito. O que eu gostaria é que a comissão, que existe hoje, chegasse a um consenso de que é preciso diminuir o volume de recursos e, portanto, fazer um exame prévio. Aparentemente parece uma violência com o direito alheio. Mas, está todo mundo esquecendo, de que o duplo grau já foi cumprido. É como se o TST raciocinasse que todos os Regionais erram, como regra. E é só pegar a estatística. Quantos processos são julgados no TST que são oriundos da $15^{\mathrm{a}}$ Região? Qual a proporção de recursos que vêm? É óbvio que a esmagadora a maioria de processos são bem julgados, porque as partes não recorrem, por esse ou aquele motivo. Então, reduzir drasticamente a quantidade de recursos de revista e agravos não ofende o direito de acesso ao Judiciário de quem quer que seja. Por quê digo que desejaria que se chegasse a um consenso? Porque eu sei que parte da comissão não vai se livrar do vício de origem, desse bendito 896-A da CLT e, portanto, votará contra a idéia de regulamentar. Talvez o consenso fosse: vamos elaborar um projeto para substituir esse e submeter ao Pleno. $\mathrm{O}$ Pleno aprova e vai ao Congresso e a gente pressiona o Congresso de tal maneira que rapidamente venha a lei. Agora, eu acho, que se não houver critério dessa natureza, não tem jeito o Tribunal vai julgar hoje mais processo que 2008, em 2009 é a mesma coisa, e nós vamos estar sempre atrasados. Eu estou aqui há 2 anos, só nesse ano de 2009, no primeiro semestre, eu julguei 6.000 processos. Se eu tinha 12.000 quando cheguei e julguei quase isso no ano anterior e esse ano eu vou bater os 10.000, deveria ter zero. Pois eu vou fechar o ano com quase o mesmo número de processos. Quando cheguei aqui eu recebi $80 \%$ de agravos de instrumento, que são muito mais simples. Nós estamos com problemas de acomodação de processos na distribuição porque eu estou recebendo só Revista. Então, a perspectiva é que em 2010 a gente trabalhe mais e produza menos. Já se avançou muito. Eu cheguei aqui, há dois anos, com processos de 98 . O gabinete está fechando agora o mês 
de novembro, terminamos os de 98 a 2005. Nós já estamos começando a examinar os de 2006.

José Pedro - Que bom, V. Exa. cumpriu a Meta 2.

Ministro Pedro Manus - Sim. Mas isso foi, o que a Meta 2 nos ajudou, foi estimular: "Oh gente, vamos ver se nós conseguimos acelerar? Vamos." Mas a que custo? Custo da qualidade. Mas que precisa uma transcendência ou coisa que o valha, não tem dúvida.

José Pedro - Muitíssimo obrigado, Ministro Pedro Manus.

\section{MINISTRO LUIZ PHILIPPE VIEIRA DE MELLO FILHO}

José Pedro - Ministro Luiz Philippe Vieira de Mello Filho, este aluno do mestrado da Faculdade de Direito do Largo de São Francisco, respeitosamente, solicita sua opinião sobre a transcendência e, afinal, se haveria necessidade de criar um filtro para os recursos de revista. Como vê V. Exa. esse problema?

Ministro Luiz Philippe - Bom, nós temos um dispositivo infraconstitucional, que estabelece a possibilidade do Tribunal Superior do Trabalho definir os critérios relativos à transcendência. Quais seriam os requisitos da transcendência? Qual é a minha preocupação? Primeiro, qual é o problema que nós temos? É o volume de processos, o volume de ação e a própria finalidade do Tribunal Superior do Trabalho. Se diz que, fixada a transcendência, o Tribunal, aí sim, julgaria as causas relevantes para o país. A minha preocupação vem daí. Primeiro pelo movimento processual, onde é que diagnosticamos a existência de uma dificuldade com relação ao tempo de dilação processual e volume de processo, porque não é importante para o Tribunal errar no foco, ou seja, tratar do efeito e não da causa. Então, a meu ver, onde está a causa? Não está no Tribunal Superior do Trabalho. O Tribunal Superior, quando foi constituído, nós tínhamos três Tribunais Regionais, hoje são 24 Tribunais Regionais. Esses 24 Tribunais Regionais, foram divididos em órgãos fracionários, em quase sua totalidade, a exceção de dois ou três Tribunais. $\mathrm{O}$ que ocorre com isso? Nós vamos chegar à função precípua do Tribunal Superior, que é uniformizar a jurisprudência na interpretação da lei federal e preservar a autoridade da lei federal do trabalho. E o que acontece? As decisões dos Tribunais Regionais do Trabalho, órgão da segunda instância, essas decisões se tornaram decisões de passagem. O que vale 
hoje no sistema trabalhista, a primeira instância e a última instância. Por quê? Porque não há uma preocupação no Tribunal Regional com a importância de uniformizar a jurisprudência local. Porque se assim fizessem, as matérias relativas a questões locais, matérias de fato, todas elas seriam resolvidas. E mais, todas elas, sendo resolvidas de forma pacífica, aumentaria o percentual, inclusive, da conciliação, porque daria segurança jurídica. Eu tenho que olhar o objetivo da lei e, não, o interesse interno da corporação. O objetivo de preservar a lei federal e uniformizar a jurisprudência, é dar segurança ao jurisdicionado. Saber o empregado quais são os seus direitos e, o empregador, quais são os seus deveres. Direitos e obrigações e vice-versa. Quando o Tribunal Regional, por seus órgãos fracionários, decide sem nenhum critério, cada qual segundo a sua conveniência ou a composição da sua Turma, ele diz assim: 'o processo vai pro TST e fica oito anos', e transfere o custo da dilação processual pro TST. A meu juízo de forma indevida, porque se eu autorizo a passagem dos recursos porque eu tenho inúmeras decisões divergentes, inclusive, dentro dos próprios Tribunais, o que eu estou fazendo? Tornando desvaliosa a decisão do Regional. O Tribunal não resolve nada. Nada vezes nada. Porque toda decisão é impugnada. Aí vem quem, quem decidiu em primeiro grau e quem vai decidir em último, que é o Tribunal Superior do Trabalho. Então, para se estabelecer política de elaboração de uma normatividade, a transcendência parte da premissa de que o problema está dentro do TST, e eu sustento que, esta a minha divergência com o Ministro Ives, que foi o propositor da regulamentação, é exatamente nesse foco. Nós não temos divergência quanto à necessidade mecanismos de solução dessa pletora de processos. Mas, aonde está o problema? Eu tenho que dar o remédio para onde está o mal, não para o efeito. Eu tenho que cessar o mal; se eu não cessar, e o mal aí, entendido entre aspas, não é no sentido negativo. Onde está a origem do problema, digamos assim.

José Pedro - Ministro, o grande problema é que, algumas pessoas não percebem que, se não vier a revista, vem para cá o agravo, o que é a mesma coisa...

Ministro Luiz Philippe - É a mesma coisa. Então, o que eu vislumbro, vou desdobrando ao longo do caminho. Qual a proposta que faço e que apresentei aos colegas? O que eu sustento é o seguinte: vamos criar um projeto de lei, em regime de urgência, levar ao Ministério da Justiça e depois encaminharmos ao Congresso Nacional, no seguinte sentido: na decisão, proferida pelo Juízo de primeiro grau, caberá recurso ordinário para o Tribunal Regional, aí a Turma decide, da maneira como ela entender de direito. É o princípio da livre convicção, da autonomia interpretativa do magistrado, diante do feito que tem em 
mãos. Não discuto, mas eu preciso preservar a segurança. Hoje, a lei diz que daí vem o recurso de revista, contra a decisão proferida em recurso ordinário. Qual é a minha proposta? Que desta decisão proferida em recurso ordinário não caberá, aí é cabimento do recurso de revista, caberá um recurso de embargos de divergência para uma sessão especializada, a ser instituída em todos os tribunais, e essa sessão deverá dizer, desde que comprovada a divergência, que a posição do Tribunal, quanto àquele dispositivo de lei federal, naquela hipótese submetida a exame, é em tal ou qual sentido, razão pela qual eu vou eliminar todas as múltiplas decisões sobre o mesmo caso, criando insegurança regional e fazendo do Tribunal Superior um órgão de revisão e, não, um órgão de uniformização. Aí, o custo do processo vai se inverter, porque ele não vir aqui e ficar aguardando julgamento para nós uniformizarmos dentro do tribunal. Nós não vamos mais uniformizar lá dentro. Porque no momento em que o Tribunal, investido dessa sessão, apreciar, ele vai dizer assim: o Tribunal, no caso, por exemplo da décima quinta região, entende-se que essa hipótese da alteração contratual não viola o artigo 468 da CLT, razão pela qual nega-se provimento ao recurso nesse sentido, não há insegurança, pacifica-se a jurisprudência. $\mathrm{O}$ que o Juiz de primeiro grau vai ter: Olha - vai dizer às partes, seja qual for - o Tribunal já deu a última palavra pela sessão de uniformização, dessa (questão não cabe), então não adianta procrastinar e recorrer do que já foi decidido. Aí vai dizer: e o TST? Dessa decisão de embargos é que caberá o recurso de revista. Mas o que estou querendo, qual o escopo dessa decisão de embargos? É um mero recurso de uniformização. É exigir que o Tribunal Regional dê a sua posição quanto à matéria, o Tribunal, não os seus órgão fracionários. E aí, por que? Porque a função precípua do Tribunal Superior do Trabalho, não é uniformizar a jurisprudência interna do Tribunal, mas entre os Tribunais. Aí, alguém vai ter que me dizer: que aquela decisão do Tribunal, viola a lei, a constituição ou diverge de outro tribunal. E aí, o Tribunal com uma única decisão, vai dizer: naquele caso não viola. E evita essa pulverização interna, dentro do TST, com as suas oito turmas, com inúmeras decisões repetitivas. E quando ele dizer "não, tá confirmado", acabou não tem mais condições de se recorrer. E o próprio Juízo de primeiro grau, que está diante das partes, ele vai ter elemento para dizer: olha vamos conciliar porque essa solução está incondicionada. E eu dou segurança jurídica, que não é resolver os processos, mas dar segurança jurídica. Então, o mecanismo tem que ter essa hibridez, tentar conciliar na medida do possível, a segurança jurídica com celeridade e não apenas ficar preocupado com o escopo estatístico. Porque decidir muito e decidir rápido não significa fazer justiça. Então, nós temos filtrar para criar justiça. Agora, o que que vai acontecer? Quando a Corte se inclinar para examinar aquela 
violação ou aquela questão jurídica, ela nos dará, ainda por cima, todos os elementos para a concreção jurídica, ou seja, todos os membros vão se manifestar, naquele julgamento, e vão trazer todos os elementos indispensáveis à análise do caso. Quantas vezes nós recebemos aqui, pulverizadamente, com recursos mal aparelhados, não conseguimos verificar a divergência e parece que estamos chancelando a decisão regional. Todas. Ainda que diversas. Então, nós estamos ficando vulneráveis, não por um equívoco nosso, mas por força do próprio sistema, que a meu juízo está equivocado. Então, nós temos que criar uma solução que estabeleça a uniformização da jurisprudência regional. Por que? Porque com a lei 9756/98 se disse o seguinte: na alínea "a" do 896, era possível a divergência dentro do mesmo tribunal, a lei 9756 disse "não, só de outro". E aí o que fez? Estabeleceu a necessidade que os tribunais se uniformizassem. Então nós tínhamos duas diretrizes, uma se cumpriu a outra não. E o sistema quebrou. Aí, nós passamos a uniformizar, o que? O próprio Regional embora com divergência de outro.

José Pedro - Exatamente.

Ministro Luiz Philippe - Então o que nós temos que fazer agora? Fechar o ciclo que não se aperfeiçoou pelo sistema da uniformização, com base no modelo do código de processo civil, mas vamos estabelecer uma legislação com embargos de divergência. Se não houver divergência de Tribunal porque eu vou recorrer para o TST? Se todas as turmas são unânimes, eu vou recorrer pro TST? Não, prevalece a decisão. Aí vai se dizer: Bom, mas e se ela violar a constituição? É recurso de última instância, se violou a constituição é pro Supremo. Ele é que vai dar a palavra. Recurso de última instância. Não cabe mais para cá, vai para o supremo e ele diz: “Ah, violou a constituição, então muda.” Agora, nós não podemos nos preocupar, em trazer uma solução interna para o TST, como se o custo fosse nosso, da demora do processo. Não é. A meu juízo não é. E mais, o que mais me preocupa, mesmo sob a égide da constituição de 67 até 88, nenhum tribunal, em tempo algum, que me recorde a memória, estabeleceu os requisitos de admissibilidade por si próprio. Jamais, em tempo algum. Porque o requisito de admissibilidade de recurso é norma processual e, além de tudo, objetiva. Agora, eu mando uma norma em branco pro Tribunal para ele dizer assim: o que eu vou receber e o que eu não vou receber? Me parece que também pelo princípio democrático, não há transparência num critério de admissibilidade de recurso de natureza subjetiva de uma própria Corte. E se eu disser que a transcendência é quase tudo? E se eu disser que a transcendência é quase nada? Então, eu não posso, eu não posso como órgão próprio, a meu juízo, na hora em que isso for regulamentado, e meu medo é 
justamente o que eu dizia no começo da conversa, a inconstitucionalidade rejeitada foi formal, mas a material não está excluída. E se eu regulamentar no sentido de criar pressupostos subjetivos de admissibilidade, nada impede que a OAB, com a legitimidade que detém pela Constituição Federal, ingresse com uma ADIn e diga: "mas olha, esse tribunal não estabeleceu isso. Ele não pode. Ele criou uma norma processual." Regulamentar critérios da transcendência não significa criar pressupostos subjetivos. Isso vai ser discutido. Acho que a questão não terá um fim. Então, vamos partir por um caminho mais objetivo. Vamos criar uma lei e, com isso, estabelecermos a uniformização lá. Agora, tem que ser acertado determinados aspectos. Para se fechar o círculo. Por exemplo, a recorribilidade direta ao Supremo, por violação, se não houver divergência. Isso, precisamos ver. Mas não podemos é construir um modelo que eu estabeleço critérios subjetivos para a Corte. Eu diria: econômico, político, jurídico e social. Eu não consigo definir, sequer, o que são esses critérios, até pela etimologia de cada palavra. Social, eu não conheço uma palavra com dimensão...

José Pedro - ...tão vasta

Ministro Luiz Philippe - ...como essa. Então, eu poderia dizer que é a própria natureza da Justiça do Trabalho; toda questão aqui tem relevância social.

José Pedro - E a econômica, vai ficar só no valor?

Ministro Luiz Philippe - A política, a transcendência política, retira da corte, que tem como função precípua a uniformização da lei federal, a sua técnica de admissibilidade científica para o exame do recurso de revista e passa para um critério político do Supremo, não nosso. Nós não temos critério político. O econômico, eu vou fazer uma discriminação, o direito de pouca monta vale, o direito de muita monta não, ou vice-versa. Por que? Aí eu me lembro de Jehering, "a Luta pelo direito". Então, eu estou dizendo que o direito de um trabalhador modesto, do interior do Piauí, que está buscando o aviso prévio, não tem transcendência para mim. Então, o Tribunal pode dizer assim: não é devido o aviso prévio para ele, ainda que ele tenha sido despedido. E fica por isso mesmo. Estou dizendo pelo aspecto da lógica do absurdo. Então, é um critério absolutamente subjetivo. E se eu disser, por exemplo, assim: "olha, a convenção coletiva celebrada pelo sindica do $\mathrm{ABC}$, ela não tem transcendência porque é um sindicato, politicamente, muito forte." Agora, a convenção coletiva, firmada pelo mesmo sindicato dos metalúrgicos do interior do 
Maranhão - Ah, essa tem transcendência, (não precisa de embargos). Quer dizer, eu já estou colocando valores, fazendo juízos de valores prévios para dizer que aquilo é possível ou não é possível. Então, por todos esses fundamentos, eu penso que sim, poderia ter um critério para a transcendência, desde que ele fosse objetivo. Por exemplo, não cabe recurso de revista contra decisão ou sentença, ou acórdão, fundada em súmula ou orientação jurisprudencial iterativa da Corte. É objetivo, eu não estou fazendo casuísmo. A parte sabe, necessariamente, aquilo que se contém, mas eu crio com isso, também, uma abertura para criar uma legitimidade, no regimento interno do Tribunal para que alguns órgãos possam impugnar determinada súmula ou orientação, aí eu tenho que abrir democraticamente. Por exemplo, OAB. Por exemplo, uma organização sindical, desde que haja uma pertinência temática e, assim, nalgumas hipóteses do Ministério Público, poderiam questionar determinadas súmulas ou OJ's. Eu abriria, um tipo, uma classe de processos respectivos aqui que pudesse. Por que? Porque eu estou travando com Súmula, objetivamente. Então eu tenho que permitir de alguém contestar, além de mim mesmo ou do advogado da causa. Então, o sistema tem que fechar como um todo, para que se possa atingir um resultado útil. Mas, eu posso regulamentar a transcendência como critério objetivo negativo. Negativo. Se eu tenho súmula ou eu tenho OJ, não pode. Ou, uma outra hipótese que pode ser imaginada, para decisões repetitivas, ou decisões que o Supremo já, pelo 518 do CPC, já tem, trazer a aplicação para cá, daqueles dispositivos que falam da decisão plenária. Nada disso cabe. Porque hoje, se se decide, ainda que de acordo com a Súmula vinculante, a parte recorre. Então, não creio, não pode. Estou reforçando aquilo que o Supremo já deu no último comando, que as pessoas não estão obedecendo. Não pode. Se decidiu de acordo com a súmula, acabou. Acabou em primeiro grau. Não precisa entrar com recurso. Se recorrer é litigância de má-fé. Então, é possível que se faça uma série de conformações de ordem legislativa e aqui, internamente, apenas como juízo objetivo-negativo, mas nunca um juízo positivo-subjetivo. Não sei se respondi tudo.

José Pedro - Muitíssimo obrigado, Ministro. 


\section{MINISTRO WALMIR OLIVEIRA DA COSTA}

José Pedro - Ministro Walmir Oliveira da Costa, agradeço, de antemão, a acolhida deste aluno que, como V. Exa. sabe, está tentando fazer um estudo sobre a transcendência. Como que vê, V. Exa. o 896-A da CLT.

Ministro Walmir Oliveira da Costa - Dr. José Pedro de Camargo, em primeiro lugar, esse tema é muito relevante e merece uma reflexão muito profunda a respeito da transcendência no recurso de revista na Justiça do Trabalho. Abstenho-me da discussão em torno do vício de origem de inconstitucionalidade da norma, por se tratar de medida provisória, uma vez, até, que o Supremo Tribunal Federal não se manifestou definitivamente sobre a matéria. Eu verifico que a transcendência, tal como idealizada, não atenderia a finalidade para a qual foi dirigida e proposta. Porque me parece que ela criaria mais conflitos do que solucionaria o processo. É que no processo do trabalho nós temos a chamada cumulação objetiva, cumulação de pedidos ou cumulação de ações. E pelo estabelecido na lei, em cada capítulo do pedido nós teríamos que examinar transcendência jurídica, econômica, social e política. E esse pressuposto prévio, teria que ser examinado, naturalmente, com antecedência, ensejaria que o advogado, em sustentação oral, pudesse defender a transcendência em seus quatro tipos e em cada capítulo do recurso, o que tomaria um tempo considerável, apenas para a admissibilidade do recurso. Ora, o instituto está posto, a norma foi criada e nós temos de regulamentá-la, conforme determina a lei. Como fazer? A comissão está estudando, mas me parece que nós poderíamos idealizar um critério objetivo da seguinte forma: Nós diríamos que possui transcendência econômica, social, política e jurídica todas as decisões, ou melhor dizendo, todos os recursos nos quais as decisões dos tribunais regionais fossem contrárias a súmula de direito material e orientação jurisprudencial do TST, ou seja, quando a decisão regional negar aplicabilidade a súmula de direito material ou orientação jurisprudencial de direito material caberia recurso de revista. Ao contrário, o recurso não seria transcendente do ponto de vista econômico, jurídico, político e social. Esse seria um aspecto. Talvez nós pudéssemos também, ao regulamentar a transcendência, criar um mecanismo, porque essa nossa transcendência, ela funcionaria como se fosse uma súmula impeditiva de recurso, que é o que está proposto no projeto de reforma constitucional, um tipo de súmula impeditiva. Nós podemos aproveitar essa regulamentação para criar alguns mecanismos objetivos também da admissibilidade do recurso de revista porque, por exemplo, na Súmula 337 há, no tocante à divergência jurisprudencial, um critério em que a parte deve demonstrar o 
conflito de teses e a parte, normalmente, não demonstra. Se limita a transcrever ementas de julgamento, sem demonstrar o conflito, e me parece que esse poderia ser considerado como um critério técnico-jurídico de não admissibilidade, por falta de transcendência também. Seria uma questão. Mas, creio que a comissão nos trará subsídio, para, se for o caso, regulamentar sem que isto traga mais trabalho para o TST, traga mais conflitos para serem resolvidos, do que a finalidade da própria transcendência, que é fazer um crivo dos recursos de revista, a fim de que o TST possa se debruçar sobre questões mais importantes, do ponto de vista jurídico, técnico, econômico e social, do que julgar quantidades de processos sem a qualidade necessária para um tribunal uniformizador da jurisprudência trabalhista. É claro que outros colegas defendem a tese de que deveria ser criado um recurso de embargos de divergência no âmbito dos tribunais regionais para obrigar a uniformização da jurisprudência e, só depois, caberia o recurso de revista para o TST. Essa tese, realmente, uma tese bastante plausível, mas nós dependemos sempre da lei e o legislador, com referência ao processo do trabalho, não tem sido muito pródigo em nos fornecer esses mecanismos de solução de conflitos, mais adequados para o nosso processo. Portanto, me parece que, nesse aspecto, se a transcendência for regulamentada nessas bases, com esse balizamento, nós poderemos ter um número de recursos consideravelmente mais reduzido; a partir daí nós poderemos nos preocupara mais com a qualidade e com as teses jurídicas mais importantes para a formação e consolidação da jurisprudência trabalhista brasileira.

José Pedro - Muito obrigado, Ministro. 


\section{CAPÍTULO III. A TRANSCENDÊNCIA}

\subsection{Pressuposto Recursal Específico}

Como visto, por força do art. $1^{\circ}$ da Medida Provisória 2226/01, acrescentou-se à CLT o 896-A da CLT, segundo o qual, o "Tribunal Superior do Trabalho, no recurso de revista, examinará, previamente, se a causa oferece transcendência com relação aos reflexos gerais de natureza econômica, política, social ou jurídica". ${ }^{253}$

É indiscutível que transcendência passa a ser elemento tipificador ou diferenciador do próprio recurso de revista, não podendo dele dissociar-se, não existindo ela de forma autônoma e sua finalidade não é a reforma do que decidiu o acórdão recorrido, mas, sim, a admissão ou o processamento da revista. Esta só será viável caso as respectivas razões demonstrem haver a transcendência, posto que, sem ela, o recurso não comportará conhecimento.

É a mesma situação vigente e praticada com a repercussão geral, cabendo aqui fazer-se referência à minuciosa dissertação de Guilherme José Braz de Oliveira , ${ }^{254}$ segundo o qual existe uma relação de prejudicialidade, ou seja, só após o reconhecimento da transcendência do recurso de revista (tal como na repercussão geral da questão constitucional) poderá o Tribunal Superior do Trabalho tratar do mérito do apelo. Trata-se de condição (antecedente e lógica) de análise do mérito, por isso que é pressuposto ou requisito de admissibilidade do recurso de revista, distinto dos genéricos e daqueles específicos, há muito previstos no art. 896 da CLT. Aliás, no particular, cabem aqui os mesmos ensinamentos de José Carlos Barbosa Moreira quando distingue os recursos

\footnotetext{
${ }^{253}$ RUSSOMANO, Mozart Victor. Direito processual do trabalho, cit., p. 91 alude às conclusões aprovadas pelo III Congresso Ibero-Americano de Direito do Trabalho, realizado em Sevilha, Espanha, no ano de 1970, dentre as quais, ao tratar dos "Recursos e Execução de Sentença na Jurisdição Trabalhista", cogita da transcendência jurídica e social como elemento a ser considerado nos recursos, o que demonstra que o assunto não é tão novo assim e, marcadamente, tem origem estrangeira.

${ }^{254}$ OLIVEIRA, Guilherme José Braz de. Repercussão geral das questões constitucionais e suas consequências para o julgamento do recurso extraordinário. 2009. Dissertação (Mestrado) - Faculdade de Direito, Universidade de São Paulo, São Paulo, 2009. P. 159 e 163. Disponível em: $<$ http://www.teses.usp.br/teses/disponiveis/2/2137/tde-16042010-

124802/publico/Guilherme_Jose_Braz_de_Oliveira_Dissertacao.pdf> Acesso em: 20 out. 2010.
} 
ordinários dos extraordinários (o que vale para o especial e para a revista), pois estes têm fundamentação vinculada ${ }^{255}$ e neles não se discutem fatos, posto que restaram soberanamente definidos nas instâncias ordinárias, o que está cristalizado nas Súmulas 279 do STF, 7/STJ e 126/TST.

Mutatis mutandis, também aplicáveis à transcendência as observações que Guilherme José Braz de Oliveira fez para a repercussão geral, asseverando que esse requisito será exigível no caso do recurso de revista adesivo, que é ônus do recorrente demonstrá-lo e não pode ser inferido ou presumido a partir das razões recursais, jamais de ofício. $^{256}$

Há, no entanto, peculiaridade para a qual não se tem atentado: a transcendência é pressuposto recursal cuja análise intrínseca (da sua própria existência e da sua demonstração) será exclusiva do Tribunal Superior do Trabalho e, não, do Tribunal Regional do Trabalho. Este ficará incumbido de, apenas, verificar se é feita a invocação da transcendência, como matéria adjunta ao mérito da revista; o Regional não se imiscuirá no mérito da transcendência. Vê-se, portanto, que inaugura-se modo sui generis de análise de pressuposto de admissibilidade, posto que até então as Cortes a quo exerciam a prévia admissibilidade sem restrições; agora não, a matéria será de apreciação exclusiva pelo TST, desde que formalmente apresentada. É o que se dá com a repercussão geral, conforme observou Guilherme José Braz de Oliveira, que identifica mera opção legislativa e, não, característica essencial nessa competência privativa do STF para apreciar esse pressuposto.$^{257}$

O conteúdo legal posto permite, destarte, que se extraiam três conseqüências: a) trata-se da criação de mais um pressuposto específico de admissibilidade do próprio recurso de revista; b) esse novo requisito consiste em exigir do Tribunal Superior do Trabalho prévio exame da matéria recursal trazida, assim devendo se entender a palavra causa (em princípio, não haveria como se voltar para a inicial e contestação, em face da

\footnotetext{
${ }^{255}$ BARBOSA MOREIRA, José Carlos. Comentários ao Código de Processo Civil. 4. ed. Rio de Janeiro: Forense, 1981. v. 4, p. 62.

${ }^{256}$ OLIVEIRA, Guilherme José Braz de. op. cit., p. 161-164. Este autor explicita que não se trata de pressuposto extrínseco, mas intrínseco, ou seja, relacionado "à própria decisão recorrida e, não, simplesmente, ao modo de se recorrer".

${ }^{257}$ Id. Ibid., p. 242, citando André de Albuquerque Cavalcanti Abbud e Arruda Alvim, este último que invoca e distingue as semelhantes situações do recurso de revisão alemão e o austríaco, no que diz respeito à análise do requisito da importância fundamental da causa pela Corte de origem no caso do recurso de revisão.
} 
restrição devolutiva recursal, que, às vezes, não diz respeito à totalidade dos pedidos/lide); c) essa análise antecedente do mérito da revista há de ficar circunscrita à existência de uma transcendência ligada a reflexos gerais de natureza econômica, política, social ou jurídica e, não, v.g., filosófica, antropológica etc.

Assim, em primeiro lugar, tratando-se de requisito ou pressuposto recursal específico, repita-se, antecedente da análise do mérito (esta é a natureza jurídica da transcendência, vale dizer, isso é o que a identifica e a contextualiza no âmbito da teoria dos recursos do processo do trabalho), claro está que a revista haverá de, antes, atender os pressupostos gerais de recorribilidade, exigíveis de qualquer recurso.

Alexandre Simões Lindoso nos dá notícia das várias classificações doutrinárias dos pressupostos de admissibilidade dos recursos ${ }^{258}$ (objetivos, subjetivos, genéricos, específicos, de admissibilidade e de cabimento) e, tendo em conta a própria diretriz que vem sendo tomada pela legislação, v.g. o art. 897-A da CLT, e pela jurisprudência, no caso, a Súmula 353/TST (ambos aludem a pressupostos extrínsecos), cabe adotar o critério classificatório que coincide com os ensinamentos de Estêvão Mallet, ${ }^{259}$ vale dizer, pressupostos extrínsecos, intrínsecos e específicos.

Numa segunda etapa, portanto, é que se faz a averiguação das exigências peculiares da revista, há muito previstas nas letras do art. 896 da CLT e nos respectivos $\S \S 2^{\circ}$ e $6^{\circ}$, ao longo do tempo com sucessivas alterações limitativas de cabimento.

Considerando-se, a título de exemplo, que o recurso de revista tenha sido admitido perante o Tribunal Regional do Trabalho, salta aos olhos que, particularmente no que se refere aos primeiros pressupostos, ou seja, se o apelo for intempestivo, se não exibir mandato em favor da parte recorrente, se estiver deserto por falta do pagamento de custas, ou, da mesma forma, pela falta do depósito recursal exigível, claro parece não chegará o Tribunal Superior do Trabalho ao exame da transcendência, no mínimo, por absoluta falta de utilidade/necessidade, em nome da economia e celeridade processuais.

\footnotetext{
${ }^{258}$ LINDOSO, Alexandre Simões. Técnica dos recursos trabalhistas extraordinários. São Paulo: LTr, 2010. p. 132-134.

${ }^{259}$ MALLET, Estêvão. Do recurso de revista no processo do trabalho, cit., p. 40 usque 73, nas quais, minudentemente, trata dos requisitos extrínsecos (tempestividade, regularidade de representação, custas do art. 789 da CLT e depósito recursal do art. 899 da CLT) dos intrínsecos (cabimento, legitimação para recorrer, interesse recursal e inexistência de fato impeditivo ou extintivo, ou seja, incompatíveis com o direito de recorrer) e dos e dos específicos (divergência e violação literal de lei e afronta direta e literal da Constituição Federal).
} 
Em segundo lugar, do modo como veio a ser formulada a regra do art. 896-A da CLT, não se extrai uma certeza acerca da maneira como o exame da transcendência há de preceder ao dos requisitos especiais de admissibilidade do recurso de revista, ou seja, a divergência jurisprudencial, violação qualificada da Constituição e de lei federal e contrariedade a Súmula, com as várias singularidades das orientações jurisprudenciais pertinentes. ${ }^{260}$

A conclusão mais lógica e mais prática a que se chega é que apenas o recurso de revista que merecer conhecimento passaria, em seguida, sob o crivo da transcendência, o que também vai ao encontro dos princípios processuais da utilidade/necessidade, na forma acima mencionada.

De fato, ainda a título de exemplo, se a jurisprudência invocada não é específica (Súmula 296/TST), se o Tribunal Superior do Trabalho, diversamente do juízo de admissibilidade a quo, reputa que a violação não é literal e que se está diante de interpretação razoável (Súmula 221/TST), que não houve o prequestionamento (Súmula 297/TST) ou que há falta a indicação do repositório autorizado, da fonte, do prolator ou não há data de publicação, de nada valerá perquirir a transcendência, previamente.

Portanto, quando o comando legal determina que o Tribunal Superior do Trabalho "examinará previamente" se a causa ostenta transcendência, tudo indica que esse momento há de ser entendido como aquele imediatamente posterior à própria confirmação do conhecimento do recurso de revista.

Noutras palavras, o Tribunal Superior do Trabalho revê, de forma independente e não vinculativa, o juízo de admissibilidade "a quo", inclusive sob aspectos não abordados pelas partes, conhece do recurso e, daí, antes de passar à análise do mérito recursal do caso concreto, deve examinar se esse mérito (do caso) ultrapassa o interesse das partes envolvidas, vale dizer, se o tema recursal está dotado de transcendência econômica, política, social e jurídica. ${ }^{261}$

\footnotetext{
${ }^{260}$ Tenham-se em conta, por exemplo, as Orientações Jurisprudenciais no ${ }^{\circ}$ 62, 118 e 119 da SBDI-1 do TST, fundamentais para a compreensão da exigibilidade do prequestionamento.

${ }^{261}$ No voto do Min. João Oreste Dalazen, presidente da Comissão Temporária criada para estudar a possibilidade de regulamentação da transcendência (cfr. infra p. 216-222) há semelhantes indagações sobre o momento dessa "prévia" análise do requisito, mormente sob o enfoque da utilidade e da necessidade processuais.
} 
A Medida Provisória, todavia, não tratou do modus operandi da transcendência, sujeitando-o àquilo que vier a ser proposto pelo próprio órgão julgador, o que é o oposto do que ocorreu com a repercussão geral da questão constitucional, tema objeto do $\S 3^{\circ}$ do art. 102 da Constituição Federal (acrescentado pela EC45/04), que exigia regulamentação legal, o que se deu com a Lei 11.418/2006, afastando-se de qualquer possibilidade de julgamento político ou discricionário, "porque a Corte deverá explicitar a respectiva ratio decidendi", no dizer de José Rogério Cruz e Tucci, citado por José Guilherme Braz de Oliveira. ${ }^{262}$

Pois bem, afora estas exemplificativas hipóteses de possível transtorno na aplicação concreta do novo pressuposto processual específico, criado pelo art. 896-A da CLT, chegase, em terceiro lugar, à discussão sobre o conteúdo semântico da própria palavra transcendência, do que, também, não escaparia aquilo que se há de entender como natureza econômica, política, social e jurídica, na verdade, outro nó górdio ou pomo de discórdia, propício para desencontro de idéias.

Confiram-se, portanto, alguns conceitos de transcendência.

De acordo com o Dicionário Houaiss ${ }^{263}$, nele existem sete acepções indicadas, das quais se extraem as seguintes:

1 caráter do que é transcendente 2 superioridade de inteligência; perspicácia, sagacidade 3 importância superior (questões de grande t.)" 4 Fil. na tradição metafísica (esp. o neoplatonismo e a escolástica), caráter inerente a um princípio ou ser divino que ultrapassa radicalmente a realidade sensível, e com a qual mantém, em decorrência de sua perfeição e superioridade absolutas, uma relação de soberania e de distância.

$\mathrm{O}$ adjetivo transcendente, por sua vez, diz respeito àquilo que

1 excede em seu gênero; excede os limites normais; superior, sublime (espírito t.) (inspiração t.)" 2 que transcende a natureza física das coisas; metafísico (entidades t.) $\mathbf{3}$ que revela perspicácia; agudo, penetrante, sagaz (inteligência t.) (olhar t.) 4 que está acima das idéias e conhecimentos ordinários (simbolismo t) (verdades t.). ${ }^{264}$

\footnotetext{
${ }^{262}$ OLIVEIRA, Guilherme José Braz de, op. cit., p. 176.

${ }^{263}$ HOUAISS, Antônio; VILLAR, Mauro de Salles. Dicionário Houaiss da língua portuguesa. Rio de Janeiro: Objetiva, 2001. p. 2749.

${ }^{264}$ Id. Ibid.
} 
Evidentemente, essas duas palavras cognatas têm origem etimológica no verbo latino transcendere, em vernáculo, transcender, que significa

passar subindo, atravessar, ultrapassar, transpor", enfim, transcender, isto é, "elevar-se sobre ou ir além dos limites de; situar-se para lá de (todos esses fatos incomuns transcendem o nosso entendimento) (são conceitos que transcendem à mediocridade dos lugares-comuns) (administrar nossas finanças transcende de suas funções de diretor). ${ }^{265}$

O Grande Dicionário Enciclopédico Verbo ${ }^{266}$, por seu turno, assim a define:

Relação oposta à imanência, designa tudo aquilo que está para além do limite ou domínio determinado. Diz respeito ao planos antropológico, gnosiológico e ontológico ou metafísico. Antropologicamente, a transcendência traduz a propriedade de o homem sair para fora de si quando pensa e age em liberdade, é a fuga à finitude e a busca de si próprio fora de si, no outro. Em gnosiologia significa que o objecto do conhecimento não está no sujeito ou a independência da consciência relativamente ao objecto conhecido. Em ontologia, a transcendência leva à superação do mundo com os seus limites e relaciona-se com o fundamento, o sentido, a causa dos seres mundanos - o que só pode ser pensada como termo de referência em analogia com aquilo que se transcende.

Já o antigo Dicionário Enciclopédico Brasileiro ${ }^{267}$ define transcendência da seguinte forma: " $f$. Qualidade do que é transcendente. Grandeza. Excelência. Fig. De grande importância. Agudeza, subtileza de inteligência. Filos. Existência de realidades transcendentes. Sistema filosófico baseado na revelação divina.”

Sob o ponto de vista da Filosofia, o Dicionário Filosófico de André ComteSponville ${ }^{268}$ estampa a seguinte definição:

É a exteriorização e a superioridade absolutas: o outro lugar de todos os aquis (e até de todos os outros lugares), e sua superação. A ausência suprema portanto, que seria também o auge da presença - o ponto de fuga do sentido. Pois "o sentido do mundo deve ser encontrado fora do mundo"' escreve Wittgenstein. A transcendência é esse fora ou o supõe.

\footnotetext{
${ }^{265}$ HOUAISS, Antônio; VILLAR, Mauro de Salles. op. cit.

${ }^{266}$ GRANDE Dicionário Enciclopédico Verbo. Lisboa; São Paulo: Editorial Verbo, 1997. v. 3, p. 633.

${ }^{267}$ MAGALHÃES, Álvaro et al. Dicionário enciclopédico brasileiro. Porto Alegre: Editora Globo, 1954. p. 1490.

${ }^{268}$ COMTE-SPONVILLE, André. Dicionário filosófico. Tradução de Eduardo Brandão. São Paulo: Martins Fontes, 2003. p. 602-603.
} 
É o Reino ausente que nos condena ao exílio. Esse sentido primeiro ou geral pode ter suas variações. É transcendente tudo o que se encontra além de. Mas além do quê? Além da consciência (é o sentido fenomenológico: a árvore que aviso não está na consciência, é um objeto transcendente para a consciência); além da experiência possível (é o sentido kantiano); além do mundo ou de tudo (é o sentido clássico).

Pode designar também o movimento que leva até aí, como que uma superação de todo dado ou de todo limite, reservada contudo ao Dasein. A liberdade, especialmente, seria esse poder de transcender toda situação, todo condicionamento, todo determinismo. Seria uma maneira de ser exterior à sua própria história, a seu próprio corpo, à sua própria situação, ou de poder sair deles. Há algo de milagroso na transcendência, uma vez que ela pretende se experimentar de dentro ou neste mundo.

Já sob o prisma do direito, a título meramente exemplificativo, De Plácido e Silva, na sua conhecida obra, Vocabulário Jurídico, não consignava verbetes para transcendência ou transcendente ${ }^{269}$, o mesmo ocorrendo com versão mais recente, atualizada a partir da $22^{a}$ edição por Nagib Slaibi Filho e Gláucia Carvalho, em razão do novo Código Civil. ${ }^{270}$

Deixando-se de lado outras tantas especulações de ordem semântica e, ainda, não se descurando do já mencionado denso conteúdo filosófico ${ }^{271}$, inegável que, no Brasil, pelo menos desde o final do século XIX (1882) ${ }^{272}$, esta palavra tem um significado corrente e vulgar que pode, por exemplo, ser encontrado em Machado de Assis, logo nas primeiras linhas do célebre conto O Espelho - Esboço de uma nova teoria sobre a Alma Humana:

\footnotetext{
Quatro ou cinco cavalheiros debatiam, uma noite, várias questões de alta transcendência, sem que a disparidade dos votos trouxesse a menor alteração aos espíritos. A casa ficava no morro de Santa Teresa, a sala era pequena, alumiada a velas, cuja luz fundia-se misteriosamente com o luar que vinha de fora. Entre a cidade, com as suas agitações e aventuras, e o céu, em que as estrelas pestanejavam, através de uma atmosfera límpida e sossegada, estavam os nossos quatro ou cinco investigadores de coisas metafísicas, resolvendo amigavelmente os mais árduos problemas do universo. ${ }^{273}$
}

\footnotetext{
${ }^{269}$ SILVA, De Plácido e. Vocabulário jurídico. Rio de Janeiro: Forense, 1963. p. 1583.

${ }^{270}$ Id. Vocabulário jurídico. 27. ed. Rio de Janeiro: Forense, 2007. p. 1422.

${ }^{271}$ BRUGGER, Walter. Dicionário de filosofia. São Paulo: Ed. Herder, 1962. p. 528-529.

${ }^{272}$ MINISTÉRIO DA EDUCAÇÃ̃O. $<$ http://machado.mec.gov.br/index.php?option=com_content\&task=view\&id=166\&Itemid=173>. Acesso em: 23 set. 2010, sítio do Domínio Público, do Ministério da Educação, que indica o ano de 1882 como o do surgimento do conto "O Espelho".

${ }^{273}$ ASSIS, Machado de. Obras completas. Rio de Janeiro: Ed. Nova Aguilar, 1992. p. 345-352.
} 
Feitas estas considerações gerais, voltando-se ao direito posto, resulta da análise do art. 896-A da CLT que o legislador usou a palavra transcendência no seu sentido mais comum, mais corriqueiro, sem que, a princípio, seja necessário enveredar por grandes investigações filosóficas.

Do texto legal se extrai uma significação corrente de uma coisa muito importante e muito relevante, que tenha reflexos tais que ultrapassam aqueles das partes primariamente envolvidas no recurso que está sendo julgado, como afirmou Wagner D. Giglio, segundo o qual, "na prática, porém, deverá prevalecer o significado comum, de superioridade ou importância". 274

É o que também inferiu Carlos Henrique Bezerra Leite ao dizer que "a mens legislatoris aponta no sentido de algo muito relevante, de extrema importância, a ponto de merecer um julgamento completo por parte do TST. De toda sorte, evidencia-se a marca da subjetividade." 275

Na mesma linha de idéias é a manifestação de Manoel Carlos Toledo Filho, segundo o qual pode-se extrair da previsão legal que

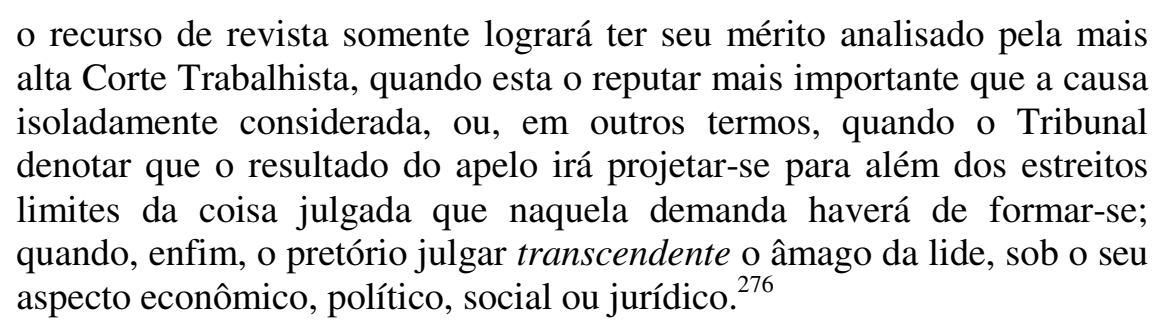

o recurso de revista somente logrará ter seu mérito analisado pela mais alta Corte Trabalhista, quando esta o reputar mais importante que a causa isoladamente considerada, ou, em outros termos, quando o Tribunal denotar que o resultado do apelo irá projetar-se para além dos estreitos limites da coisa julgada que naquela demanda haverá de formar-se; quando, enfim, o pretório julgar transcendente o âmago da lide, sob o seu aspecto econômico, político, social ou jurídico. ${ }^{276}$

Pode-se concluir, portanto, que este novo pressuposto específico, a transcendência, contrariamente ao que se dá com os dois outros, os quais, salvo variações ao longo do tempo, tem sido definidos no art. 896 da CLT (divergência e violação), bem assim com os demais requisitos genéricos antecedentes (extrínsecos e intrínsecos), ele não têm definição legal precisa, conhecida ou já sedimentada, como é o caso, e. g., da tempestividade, representação, sucumbência, do preparo, interesse recursal e prequestionamento, daí por

\footnotetext{
${ }^{274}$ GIGLIO, Wagner D. O requisito prévio da transcendência. Revista LTr, São Paulo, v. 66, n. 1, p. 16, jan. 2002.

${ }^{275}$ LEITE, Carlos Henrique Bezerra. op. cit., p. 778.

${ }^{276}$ TOLEDO FILHO, Manoel Carlos. op. cit., p. 151.
} 
que necessita de integração normativa por parte do Tribunal Superior do Trabalho e de construção jurisprudencial definidora da sua essência.

Essa lacuna poderia ter sido suprida, desde a vigência da Medida Provisória 2226/01, se o Tribunal Superior do Trabalho houvesse cumprido a determinação do art. $2^{\circ}$ dessa MP, regulamentando em seu Regimento Interno o processamento da transcendência, mas, como é notoriamente sabido, não o fez, passados mais de nove anos e, à vista do que concluiu a última Comissão da Transcendência, não irá fazê-lo, ficando descartado o requisito idealizado pelo Poder Executivo.

Nesse quadro, o preceito legal também deixa de ser vivificado pela prática quotidiana e pela sedimentação da experiência de sua aplicação, autênticas formas de demonstração do atingimento das finalidades buscadas com a instituição desse novo requisito, o que parece estar mais longe de acontecer. ${ }^{277}$

A situação anterior e a hodierna da transcendência frusta a compreensão e a interpretação da própria regra jurídica criada, na medida em que pouco ou nada se desprendeu do seu criador, até agora, ato unipessoal do Presidente da República, por meio de medida provisória, cuja edição, inclusive, é constitucionalmente questionada, o que não passou despercebido por Luiz Manoel Gomes Júnior, autor de um dos primeiros artigos que tratou da transcendência do recurso de revista (novembro de 2001). ${ }^{278}$

A própria existência objetiva da regra, com mera força de lei, fica comprometida pela maneira como engendrada, dependente da atuação legislativa complementar de ramo do Poder Judiciário, sem o influxo normal, lógico e constitucional que estaria e está afeto ao Poder Legislativo.

\footnotetext{
${ }^{277}$ OLIVEIRA, Guilherme José Braz de, op. cit., p. 133-143 analisa a transcendência do recurso de revista, nela identificando a primeira tentativa criação de restrição de acesso aos Tribunais Superiores. Faz específica alusão ao Projeto de Lei 3267/2000, o qual, todavia, como se viu, não está mais em tramitação, arquivado que foi a requerimento do Poder Executivo, de sorte que não tem mais sentido a alusão a possível redação que se pretenda conferir a incisos do art. 896-A da CLT, pois este tem a redação que lhe deu a MP 2226/01.

${ }^{278}$ GOMES JUNIOR, Luiz Manoel. O pressuposto da transcendência no recurso de rvista - Art. 896 da CLTConsiderações iniciais. Revista LTr, São Paulo, ano 65, n. 11, p.1302-1311. Logo na primeira nota de rodapé desse artigo está posta a questão da inconstitucionalidade da medida provisória, mas o Autor propõe-se não abordar esse aspecto. Tece, no entanto, conjecturas do que haveria de ser entendido por transcendência econômica (discussão sobre correção salarial) política (sobre aumento de servidores públicos submetidos à CLT) etc.
} 
E, mesmo correndo o risco de passar pelo assunto como por sobre brasas, cabe aqui referir que a construção do requisito recursal, transcendência, toca num ponto crucial da ciência jurídica que é a interpretação e a aplicação da lei, e, também, a fecunda relação entre direito e linguagem. ${ }^{279}$

De fato, quando as palavras utilizadas na legislação têm conteúdo aberto e impreciso, assim postas de propósito, muitas vezes, objetivam, seja buscada, uma outra forma de solução mais efetiva e eficaz dos conflitos no tempo, tal como prelecionou José Manoel de Arruda Alvim Neto. ${ }^{280}$

Karl Engish, abordando a inconclusiva problemática sobre a luta das teorias subjetivas e objetivas de interpretação da norma jurídica, esclarece, em resumo, que a primeira delas parte da análise recuperadora da intenção do legislador e a segunda reconhece que a lei adquire existência própria ao ser posta no mundo jurídico, desprendendo-se por completo do seu autor, cujas representações e expectativas, "que em volta dele pairam, não adquiriram caráter vinculativo algum,"281

E, acrescenta Karl Engish:

O sentido incorporado na lei pode também ser mais rico do que tudo aquilo que os seus autores pensaram ao realizar o seu trabalho - quando pensaram sequer algo, o que nem sempre se poderá afirmar em relação aos parlamentares que votaram uma lei. A própria lei e o seu conteúdo interno não são uma coisa estática como qualquer facto histórico passado ("eternamente quieto permanece o passado"), mas são algo de vivo e de mutável e são, por isso, susceptíveis de adaptação. O sentido da lei logo se modifica pelo facto de ela constituir parte integrante da ordem jurídica global e de, por isso, participar de sua constante transformação, por força da unidade da ordem jurídica. ${ }^{282}$

Daí esse mesmo autor expor a seguinte diretriz:

\footnotetext{
${ }^{279}$ Veja-se, dentre outros autores, DINIZ, Maria Helena. Compêndio de introdução à ciência do direito. 19. ed. São Paulo: Saraiva, 2008. p. 169-170, nas quais, abordando a linguagem e a ciência jurídica, faz relevante síntese no sentido de que "o intérprete deve partir das palavras para atingir a idéia."

${ }^{280}$ ALVIM NETO, José Manoel Arruda. A arguição de relevância no recurso extraordinário. São Paulo: Ed. Revista dos Tribunais, 1988. p. 14. Logo mais abaixo, procurar-se-á expor, com mais detalhes, o pensamento deste autor, que via na relevância instrumento adequado (porque flexível) para a seleção dos verdadeiros problemas que merecem solução pelos poderes públicos e pela Suprema Corte.

${ }^{281}$ ENGISH, Karl. Introdução ao pensamento jurídico. 6. ed. Lisboa: Fundação Calouste Gulbenkian, 1988. p. 172.

${ }^{282}$ Id. Ibid., p. 173.
} 
Não pode ser nossa tarefa deixarmos o presente com os seus problemas e retrocedermos anos ou décadas para entrar no espírito de um legislador que propriamente nos não interessa já. Logo: interpretatio ex nunc e não interpretatio ex tunc. A partir da situação presente é que nós, a quem a lei se dirige e que temos de afeiçoar de acordo com ela a nossa existência, havemos de retirar da mesma lei aquilo que para nós é racional, apropriado e adaptado às circunstâncias. ${ }^{283}$

Hans Kelsen não destoava dessas idéias. Para o autor austríaco, interpretar consiste em, basicamente, responder-se à questão de saber qual o conteúdo individualizado que se deve dar àquela norma geral para o caso concreto, trate-se de uma decisão judicial ou administrativa; noutras palavras, a interpretação é indissociável da aplicação ou da busca do sentido e alcance das normas (na sua forma original e geral) que vão ser aplicadas para o caso específico. ${ }^{284}$

De fato, na maioria das vezes o direito posto não é unívoco nem poderia abordar todos os aspectos da realidade, sob pena de ficar restringido a uma época passada e determinada e não ter eficácia prospectiva, por isso que deve corresponder a uma "moldura dentro da qual existem várias possibilidades de aplicação." 285

Simplesmente, a indeterminação do ato jurídico pode também ser a
consequiência não intencional da própria constituição da norma jurídica
que deve ser aplicada pelo ato em questão. Aqui temos em primeira linha
a pluralidade de significações de uma palavra ou de uma seqüência de
palavras em que a norma se exprime: o sentido verbal da norma não é
unívoco, o órgão que tem de aplicar a norma encontra-se perante várias
significações possíveis. A mesma situação se apresenta quando o que
executa a norma crê poder presumir que entre a expressão verbal da
norma e a vontade da autoridade legisladora, que se há de exprimir
através daquela expressão verbal, existe uma discrepância, podendo em
tal caso deixar por completo de lado a resposta à questão de saber por que
modos aquela vontade pode ser determinada. De todo o modo, tem de
aceitar-se como possível investigá-la a partir de outras fontes que não a
expressão verbal da própria norma, na medida em que possa presumir-se
que esta não corresponde à vontade de quem estabeleceu a norma.

De acordo com Tércio Sampaio Ferraz Júnior, também analisando o pensamento de Kelsen a respeito, seria errôneo e ilusório tentar buscar um sentido unívoco das palavras

\footnotetext{
${ }^{283}$ ENGISH, Karl. op. cit., p. 173-174.

${ }^{284}$ KELSEN, Hans. Teoria pura do direito. 6. ed. São Paulo: Martins Fontes, 1998. p. 387.

${ }^{285}$ Id. Ibid., p. 390.

${ }^{286}$ Id. Ibid., p. 389.
} 
da norma porque isso desbordaria dos propósitos da ciência jurídica, a quem incumbe descrever o direito com rigor, segundo um método aceito e de acordo com regras formais e materiais. Afinal,

\begin{abstract}
se o objeto da hermenêutica são conteúdos normativos essencialmente plurívocos, se o legislador, porque age por vontade e não por razão, sempre abre múltiplas possibilidades de sentido para os conteúdos que estabelece, então à ciência jurídica cabe descrever esse fenômeno em seus devidos limites. Isto é, apenas mostrar a plurivocidade. Querer, por artifícios, ditos metódicos, ir além dessa demonstração, tentar descobrir uma univocidade que não existe, é falsear o resultado e ultrapassar as fronteiras da ciência. ${ }^{287}$
\end{abstract}

De qualquer maneira, porém, retomando o pensamento de Karl Engish, se, de um lado, não deve nem tem sentido o intérprete fixar-se naquilo que originariamente havia idealizado o legislador e, afinal, foi concretizado na lei, de outra parte, todavia, não poderá fugir dos limites objetivos postos pela própria norma jurídica, ignorando o papel "políticodecisório que a legislação também tem na democracia" ${ }^{288}$ e correndo o risco de conferir demasiada autonomia aos demais poderes incumbidos de cumprir e fazer cumprir as leis, o que pode conspirar contra a coesão do Estado e o princípio da legalidade, que por longos anos vem sendo moldado.

Há de ser construída, portanto, uma interpretação que extraia das palavras da lei um sentido razoável imanente, que não contradiga "a vontade claramente recognocível do legislador". 289

Isto, no entanto, parece difícil de se extrair da exposição legal do novel pressuposto recursal específico do recurso de revista, a denominada transcendência e, ainda mais, porque veio ela associada a reflexos gerais de natureza econômica, política, social e jurídica, vale dizer, aumentando a indefinição ou fluidez conceitual do texto.

Está-se, portanto, diante de um conceito indeterminado, “cujo conteúdo e extensão são em larga medida incertos" ${ }^{290}$; ele carece de uma valoração e daí a subsequente dúvida

\footnotetext{
${ }^{287}$ FERRAZ JR., Tercio Sampaio. Introdução ao estudo do direito: técnica, decisão, dominação. 4. ed. São Paulo: Atlas, 2003. p. 263.

${ }^{288}$ ENGISH, Karl. op. cit., p. 181, aonde, também, (apesar das críticas) este autor vê grande importância na "exposição de motivos" para a correta interpretação da lei, desde que ela mesma não indique sentido específico. E já se aludiu anteriormente ao peculiar e decisivo papel que a exposição de motivos parece desempenhar nas medidas provisórias, que têm origem na vontade do Chefe do Poder Executivo.

${ }^{289}$ ENGISH, Karl. op. cit., p. 203, nota 10.

${ }^{290}$ Id. Ibid., p. 208.
} 
que surge é saber quem estará incumbido de fazer o "preenchimento valorativo",291, se, apenas, o aplicador do direito ou se, antes, hão de ser buscadas volorações preexistentes, aceitas pela maioria das pessoas ou por parte significativa delas.

A transcendência, da maneira como posta na Medida Provisória 2226/01, não dá uma resposta imediata a estas questões o que supõe-se tornar mais complicada sua conformação prática, aqui residindo, talvez, um dos fortes motivos para que o Tribunal Superior do Trabalho venha se recusando a fazer a regulamentação desse pressuposto, como, de fato, afirmou a Comissão de Transcendência e, oportunamente, se verá.

Em conclusão, portanto, não fosse o alto teor de equivocidade que a palavra transcendência tem, de outro, como se disse, estando ligada a questões econômicas, políticas, sociais e jurídicas, tal como diz o art. 896-A da CLT, mais elevado ficará o grau de incerteza em torno de um pressuposto recursal específico, o que, no mínimo, destoa da tradição jurídica lusitana e brasileira e pode comprometer, nalguma medida, o devido processo legal, que exige certeza e definição das regras processuais no ambiente do Estado Democrático de Direito. ${ }^{292}$

E, (confirme-se) nem antes assim foi tratada a transcendência na sua primeira versão: como se viu no Capítulo II, ao encaminhar o Projeto de Lei 3267/00, ${ }^{293}$ o Poder Executivo teve o cuidado de tentar definir o que haveria de ser entendido como transcendência jurídica, política, social e econômica, sendo oportuno relembrar:

Art. 896-A. O Tribunal Superior do Trabalho não conhecerá de recurso oposto contra decisão em que a matéria de fundo não ofereça transcendência com relação aos reflexos gerais de natureza jurídica, política, social e econômica.

$\S 1^{\circ}$ Considera-se transcendência:

I - jurídica, o desrespeito patente aos direitos humanos fundamentais ou aos interesses coletivos indisponíveis, com comprometimento da segurança e estabilidade das relações jurídicas;

II - política, o desrespeito notório ao princípio federativo ou à harmonia dos Poderes constituídos;

\footnotetext{
${ }^{291}$ ENGISH, Karl. op. cit., p. 213.

${ }^{292}$ Como se verá, oportunamente, sob o magistério de José Manoel de Arruda Alvim Neto, o uso de conceitos indeterminados na lei insere-se numa nova visão da função social e política do arcabouço jurídico e dos órgãos estatais de sua aplicação, do que foi um exemplo a antiga arguição de relevância.

${ }^{293}$ Vide supra, p.70-72
} 
III - social, a existência de situação extraordinária de discriminação, de comprometimento do mercado de trabalho ou perturbação notável à harmonia entre capital e trabalho;

IV - econômica, a ressonância de vulto da causa em relação a entidade de direito público ou economia mista, ou a grave repercussão da questão na política econômica nacional, no segmento produtivo ou no desenvolvimento regular da atividade empresarial.

(definições existentes no projeto de lei 3297/2000)

A Medida Provisória 2226/01, que poderia evitar uma longa e indefinida discussão conceitual sobre os quatro tipos de transcendência, no entanto, não retomou ou insistiu nessas definições, deixando-as ao largo ou, quem sabe, relegando-as ao exclusivo arbítrio de quem fosse fazer a regulamentação, o que, afinal, também não contribuiu para aplicação imediata do critério de admissibilidade engendrado.

Interessante notar que a Medida Provisória 2226/01, propositadamente ou, não, e em sentido antagônico ao que acima constou do referido Projeto de Lei, escolheu outra ordem daquilo que haveria de ser considerado transcendente, principiando com a transcendência econômica, política, social e jurídica.

De fato, ainda que não se aceite que o art. 896-A da CLT tenha estabelecido uma intencional hierarquia ou preponderância entre os reflexos de natureza econômica, política, social e jurídica, parece intuitivo que, tratando-se de pressuposto recursal específico, considerados os propósitos da existência do próprio recurso de revista (afirmação e prevalência uniforme da autoridade da Constituição e da Lei Federal) talvez fosse o caso de priorizar o aspecto jurídico e o social, por se tratar de instrumento que colabora com a concretização da lei trabalhista e, também, por causa da perigosa e imponderável senda que se abre ao se invocarem os adjetivos político e econômico.

Note-se, a título de comparação, que o Legislador que deu concretude ao $\S 3^{\circ}$ do art. 102 da Constituição Federal, introduzido pela Emenda Constitucional 45/04 e que previu a necessidade de o requerente demonstrar a repercussão geral das questões constitucionais a serem submetidas ao Supremo Tribunal Federal, no julgamento do recurso extraordinário, faz expressa menção à relevância das questões sob o ponto de vista econômico, político, social e jurídico, conforme a redação do $\S 1^{\circ}$ do art. 543-A do CPC (aqui a ordem indicativa dos adjetivos ligados à relevância é a mesma da MP 2226/01). No 
entanto, o $§ 3^{\circ}$ já deixa explícito que haverá repercussão geral "sempre que o recurso impugnar decisão contrária a súmula ou jurisprudência dominante do Tribunal”.

A questão jurídica, em si mesma, portanto, parece merecer certa preponderância e é natural que assim seja, tratando-se de recurso destinado a unificar a interpretação de legislação federal.

De outro lado, porém, se as definiçõoes legais não constituem o ponto forte da Medida Provisória 2226/01, ao menos, afastou-se ela de inusitada proposta no Projeto de Lei $3267 / 00$, pois ali seriam inseridos os $\S \S 1^{\circ}$ e $2^{\circ}$ ao art. 896-A da CLT.

Estes parágrafos autorizavam o Tribunal Superior do Trabalho a abrir prazo para que a parte suprisse "pressuposto extrínseco de admissibilidade"; eles também permitiam o conhecimento de recurso fundado "em aspecto processual da causa, salvo com apoio em disposição constitucional direta e literalmente violada, quando o tema de fundo estiver pacificado em sua jurisprudência no sentido da decisão proferida pelo tribunal inferior." 294

Não bastassem as contundentes críticas feitas pela Comissão de Constituição e Justiça da Câmara dos Deputados, por ocasião da análise daquele Projeto de Lei, e que já foram acima reproduzidas, ${ }^{295}$ certo é que reabrir prazo para que a parte recorrente possa suprir requisito extrínseco, além de quebrar a paridade de armas que deve existir entre os litigantes e de desconsiderar as preclusões que movem o processo para frente, significaria retrocesso histórico flagrante.

Com efeito, essa magnanimidade e condescendência (de todo injustificáveis na atualidade) chegou a ocorrer ao tempo dos recursos de graça especialíssima (Século XVIII), quando o processamento desse apelo e a superação de pressupostos, mesmo quando não atendidos pela parte, ficavam dependentes da exclusiva boa vontade e da munificência do Rei, tal como foi mencionado Capítulo I. ${ }^{296}$

\footnotetext{
${ }^{294}$ Não passa despercebida curiosidade redacional do Projeto de Lei 3267/00, que, ao se referir ao Tribunal Superior do Trabalho, nos $\S \S 2^{\circ}$ e $3^{\circ}$, tratou-o como "O Tribunal", com letra maiúscula, e, ao aludir ao grau de jurisdição imediatamente anterior, vale dizer, o Tribunal Regional do Trabalho, veio a identificá-lo como "tribunal inferior" e, ainda, com letra minúscula.

${ }^{295}$ Vide supra, p. 77-79.

${ }^{296}$ Vide supra, p. 43-46.
} 


\subsection{Pontos de Convergência: Relevância e Repercussão Geral}

Logo na introdução, disse-se que o processo do trabalho não tem acompanhado os bons ventos que mais recentemente sopram do processo civil, estes em boa parte fruto da chamada Reforma do Judiciário, ainda não ultimada, mas que resultou na Emenda Constitucional 45/04 e, pouco depois, numa série de leis, dentre elas se destacando a que disciplinou a repercussão geral no STF ( Lei 11.418/06) e a tramitação dos processos repetitivos, tanto no STF, como no STJ (Lei 11.672/08), sem falar na simplificação do cumprimento das decisões e das execuções.

Afora a bem sucedida introdução do procedimento sumaríssimo (Lei 9957/00) e a criação das Comissões de Conciliação Prévia (Lei 9958/00), notoriamente desacreditadas porque pretendem ser fonte de renda para particulares, a mais atual e impactante novidade no processo do trabalho continua sendo a transcendência como pressuposto do recurso de revista.

A transcendência, porém, não surgiu do nada (reveja-se a sua exposição de motivos da Medida Provisória 2226/01, antes transcrita, no capítulo II) e, confessadamente, levou em consideração a experiência do Supremo Tribunal Federal ao tempo em que existia a arguição de relevância, reportando-se também a algumas experiências estrangeiras no trato dos processos que são submetidos ao tribunal de cúpula do Judiciário.

A instituição da transcendência do recurso de revista está muito ligada, portanto, ao recurso extraordinário constitucional e pode-se dizer que a Medida Provisória 2226/01, se não ajudou o processo do trabalho em si, porque ineficaz, abriu o caminho para que, depois de expressa autorização constitucional ( $\$ 3^{\circ}$ do art. 102), viesse a ser instituído o requisito da repercussão geral, que deu nova feição ao recurso extraordinário.

E, com grande dose de probabilidade, acredita-se que a exitosa prática da repercussão geral repercutirá no recurso especial do STJ e no recurso de revista do TST.

Nessa linha de idéias, sem a intenção de exame exaustivo e minucioso, reputa-se oportuno avivar alguns traços marcantes da antiga arguição de relevância (anos 70/80) e cotejá-la com a repercussão geral (2008), identificando os propósitos convergentes de ambas, no meio delas mais inerte a transcendência do recurso de revista (2001). 
A Constituição Federal de 1988 quebrou padrão anterior aplicável ao exame ou cabimento do recurso extraordinário: tal como antes explanado, na forma da tradição constitucional brasileira, basicamente, esse apelo poderia ser manejado caso a decisão recorrida contrariasse a Constituição Federal, negasse vigência a tratado ou a lei federal e ostentasse interpretação divergente dada por outro Tribunal ou pelo próprio Supremo, sendo esta a regra da Constituição de $1967 .{ }^{297}$

E, como se sabe, também, houve notável peculiaridade introduzida pela Emenda Constitucional $n^{o} 1 / 69$ no tocante à competência recursal e à forma de julgamento dos recursos extraordinários: o parágrafo único do inciso III do art. 119 estabelecia que as “causas a que se refere o item III, alíneas $a$ e $d$, dêste (sic)artigo, serão indicadas pelo Supremo Tribunal Federal no regimento interno, que atenderá à sua natureza, espécie ou valor pecuniário."(g.n.) ${ }^{298}$

E, não fora a só possibilidade de o Regimento Interno do Supremo indicar as causas recorríveis extraordinariamente, observando a natureza, espécie e valor, a Emenda Constitucional $n^{\circ}$ 07, de 1977, aposta à Emenda Constitucional n01/69, no bojo do célebre "pacote de abril" de 1977, criou a chamada relevância da questão federal, cuja forma de apreciação também haveria de ser definida no Regimento Interno da Corte Suprema. $^{299}$

Àquela época estabeleceu-se o que José Rogério Lauria Tucci e José Rogério Cruz e Tucci denominaram "dupla normatividade, de sorte a resultar da concorrência dos pressupostos constitucionais com os previstos no Regimento Interno da Suprema Corte de Justiça da República.” (g.n.) ${ }^{300}$

Tudo isso, porém, que não sobreviveu à Carta Política de 1988, deixou marcas e lembranças, tanto assim que veio a ser ressuscitado exatamente com a Medida Provisória 2226/01, na criação da transcendência do recurso de revista, e, quatro anos depois, com a

\footnotetext{
${ }^{297}$ Constituição Federal de 1967, art. 114, letras "a” e "d”, verificáveis no sítio da Presidência da República BRASIL. Constituição da República Federativa do Brasil de 1967. Disponível em: <http://www.planalto.gov.br/ccivil_03/Constituicao/Constituicao67.htm>. Acesso em: 13 out. 2010.

${ }^{298}$ Emenda Constitucional n ${ }^{\circ} 1 / 69$, art. 119, parágrafo único, verificável no sítio da Presidência da República, BRASIL. Emenda Constitucional n. 1 , de 17 de outubro de 1969. Disponível em: <http://www.planalto.gov.br/ccivil_03/Constituicao/Emendas/Emc_anterior1988/emc01-69.htm>. Acesso em: 13 out. 2010.

${ }^{299}$ Emenda Constitucional no $1 / 69$, art. 119, III, $\S \S 1^{\circ}$ e $3^{\circ}$, letra "c", na forma da nota de rodapé anterior.

${ }^{300}$ TUCCI, Rogério Lauria; CRUZ E TUCCI, José Rogério. Constituição de 1988 e processo. São Paulo: Saraiva, 1989. p. 118.
} 
Emenda Constitucional 45/04, que instituiu a repercussão geral do recurso extraordinário e consagrou, agora de forma definitiva e com explícito apoio constitucional, o efeito erga omnes das decisões proferidas em ADIs e ADCs.

Cabe, portanto, refletir um pouco sobre a arguição de relevância da questão federal e sobre as heranças que deixou, considerando-se, também, um certo "DNA" comum que ostentam esses recursos (extraordinário, especial e o de revista), qual seja, a influência americana do writ of certiorari, o qual, como se sabe, em linhas gerais que logo mais serão sintetizadas, permite aos julgadores escolher se irão decidir o apelo extremo, fazendo-o através de critérios que os próprios Juízes da Suprema Corte Americana estabelecem. ${ }^{301}$

Assim, ao tratar do antigo requisito da relevância, há de ser feita a invocação dos ensinamentos de José Manoel de Arruda Alvim Neto, o qual, em obra específica sobre a matéria, ${ }^{302}$ principia por destacar (invocando Ortega y Gasset) que o século XX caracterizou-se pelo acesso que as massas populares tiveram ao poder, aqui também compreendendo a maior busca da atuação do Judiciário, circunstância, até, que revelou-se bem mais notória com o advento da Constituição de 1988.

Sendo o Direito um significativo instrumento de controle social, considerando-se a inesperada demanda havida e a ineficácia das soluções tradicionais disponíveis, era necessária a busca de novas fórmulas. De fato:

O que se pode asseverar é que o instrumental clássico, conhecido com representativo da dogmática jurídica, tem-se evidenciado como insuficiente para a solução de muitíssimos dos problemas atuais, que agitam as sociedades contemporâneas. Esses instrumental, "antigo", sob certo ângulo, nos dias de hoje, em verdade, apenas "resolveria" os problemas, a nível de escolas de Direito e no patamar da soluções judiciárias, num plano de discussões centradas em a norma, mas, em escala apreciável, desligado de ponderáveis aspectos da realidade contemporânea. Todavia não se poderá dizer que esse aparato tradicional, verdadeiramente, os solucionará, de forma efetivamente satisfatória, e, muito menos, que representará uma equação "verdadeira" (rectius, satisfatória), de toda a problemática jurídica contemporânea. ${ }^{303}$

\footnotetext{
${ }^{301}$ Muito poderia ser explanado sobre o papel da Suprema Corte Americana, que serviu de modelo para o Supremo Tribunal Federal, logo no início da República, como já aludido ao tratar da gênese do recurso de revista (Capítulo I, 1.4), o que, infelizmente, desbordaria dos propósitos desta dissertação, daí por que se remete à obra já citada de Osmar Mendes Paixão Côrtes e à dissertação de mestrado de Guilherme José Braz de Oliveira, dentre outros.

${ }^{302}$ ALVIM NETO, José Manoel Arruda. op. cit.

${ }^{303}$ Id. Ibid., p. 2, 56 e 57, particularmente a nota de rodapé 34.
} 
A primordial intenção que Arruda Alvim Neto vê nessa busca de novos parâmetros de solução dos problemas sociais, mormente nesta quadra de descoberta e de grande acesso ao Judiciário, está em imprimir às ciências, em geral, e, ao Direito, em particular, com vistas à concretização do valor Justiça, um predominante resultado útil, concreto e histórico, pois o "aparato estatal há de, efetiva e eficientemente, abranger um número, cada vez maior, de jurisdicionados, transmudando-os de jurisdicionados formais, em jurisdicionados substanciais." 304

O direito posto e a atuação jurisdicional converter-se-ão em fonte de credibilidade e de estabilidade social pela obediência que conseguirem atingir, solucionando o maior número de conflitos e, também, apresentando exemplos de conduta conectados com a realidade, pois não bastam só as promessas da ordem jurídica, que correm o risco de se tornarem vãs e ocas, se não atingirem o maior número possível dos membros da sociedade, que nela buscam sua inclusão como cidadãos, retirando-os da periferia dos direitos. Nessa linha de raciocínio, as controvérsias doutrinárias e jurisprudenciais não podem impedir que se construa uma certeza jurídica ponderável, em determinado momento histórico.

Tem de existir essa certeza, ainda que se viva em uma época socialmente instável. A decisão certa, em verdade, situa-se no plano da operatividade do Direito, ao passo que, a discutibilidade da própria validade dos pressupostos, sedia-se em nível teórico, enquanto não imediatamente conectados ou influentes na operatividade mesma do Direito. ${ }^{305}$

Este mesmo Autor constatou insatisfação de grande parte dos juristas contemporâneos com as "soluções jurídicas puramente defluentes de uma visão e aplicação do Direito estritamente confinadas à dogmática jurídica tradicional."

Por isso (conclui), a atualidade está a exigir uma metodologia de aplicação do direito e, particularmente, da maneira de decidir, que não se restrinja à subsunção ou à

\footnotetext{
${ }^{304}$ ALVIM NETO, José Manoel Arruda. op. cit., p. 5, sendo o itálico próprio do original. Quanto ao fenômeno constatado no último quartel do século passado, atinente ao incremento de acesso ao Judiciário, essencial a remessa às p. 60-62, em particular à nota de rodapé 37, na qual Arruda Alvim Neto relembra a célebre pesquisa de Mauro Capelletti e de Bryant Garth intitulada "The Newest Wave in the Worldwide Movement to Make Rigths Effective". Desse fenômeno não escapou o Brasil, tendo sido notório um alargamento dos órgãos de primeiro grau de jurisdição, continuando, todavia, mais ou menos estáveis o número de assentos dos Tribunais intermediários e, sem dúvida inalterado, o da Suprema Corte. Essa circunstância reforçou a idéia de critérios de triagem dos processos a serem julgados em sede extraordinária, que, por sua vez, no nosso caso, descendentemente, se alastrou para o Tribunal Superior do Trabalho e para o Superior Tribunal de Justiça.

${ }^{305}$ Id. Ibid., p. 9 , sendo o itálico próprio do original.

${ }^{306}$ ALVIM NETO, José Manoel Arruda. op. cit., p. 10.
} 
dedução clássicas, mas que incluam aspectos outros que atendam às necessidades sociais e econômicas, em busca de

\begin{abstract}
uma "jurisprudência política", a qual se configura a partir da compreensão do Direito positivo, sob a ótica do seu papel, no contexto político e histórico. O que se objetiva com isso é o incorporar, nesta quadra histórica, o tema dos valores (ou de um novo modo, mais intenso e efetivo de realização dos valores), "atrelando-os" à dogmática tradicional do Direito. ${ }^{307}$
\end{abstract}

De fato, a análise da multifacetária realidade não mais poderia caber no enclausurado e inflexível método lógico e dedutivo (cerne da dogmática ou do pensamento sistemático, que parte do todo para as partes), pelo menos de forma isolada, daí por que José Manoel de Arruda Alvim Neto, apoiando-se em Nicolai Hartmann, advoga maior uso do método apóretico ou tópico, que tem como ponto de partida o problema constatado, sem que se tenha uma solução já delineada. E acrescenta:

O método tópico de pensamento (que funciona, indiscutivelmente, para casos originários de relevância), convive, ainda que não no mesmo espaço, e, nem, sobrepostamente, com o método dedutivo, aplicável este, a partir e em função de hipóteses precedentes (v. $n^{\circ} 2$, introdução).

O método tópico ou problemático identificará, pela primeira vez, uma hipótese. Ao depois de percebido e identificado o caso, o método adequado será o dedutivo, para hipótese que com essa se identifique. ${ }^{308}$

Destarte, como a lei, dificilmente, conseguiria abarcar toda a realidade e expor as premissas das soluções desejáveis, sob aquele espectro mais amplo de visão da sociedade, há de se conceder ao seu aplicador uma liberdade maior nesse mister, daí "falar-se, hodiernamente, em hermenêutica construtiva, que consiste numa aplicação da lei com "função normativa", ou seja, se se quiser, uma interpretação normativa". ${ }^{309}$ A tarefa do Direito, portanto, não estaria limitada ao tratamento da normatividade pura, "expungida de quaisquer outros fatores (que seriam não influentes, porque estranhos ao Direito), mas, se a

\footnotetext{
${ }^{307}$ ALVIM NETO, José Manoel Arruda. op. cit., p. 11, reiteradas as mesmas idéias às páginas 38 e 158.

${ }^{308}$ Id. Ibid.

${ }^{309}$ Id. Ibid., p. 13.
} 
norma diz com fatos, segue-se que, na ciência do Direito há juízos [de valor] sobre normas e sobre fatos." 310

Nessa linha de idéias, a arguição de relevância representou a primeira autorização legal para que o exercício da atividade judicial levasse em conta a busca e a criação de uma solução mais justa e adequada para a sociedade heterogênea em que se vive, daí o uso de termos vagos ou de categoria jurídicas flexíveis, desvinculando-se o juiz do mero e tradicional apego à letra da lei. E, invocando Karl Engish, arremata José Manoel de Arruda Alvim Neto:

O que nos parece mais relevante, todavia, ter-se presente, é que com o próprio método do Direito, através dos conceitos jurídicos indeterminados (ou vagos), dos conceitos [propriamente] discricionários, das cláusulas gerais e dos conceitos normativos, deliberadamente, se abre margem a uma interpretação afeiçoada às peculiaridades do caso concreto, e, pois, à individualização de todas as hipóteses à luz da "ratio legis". ${ }^{311}$

O uso de termos mais vagos na Constituição e nas Leis também permitiria que os julgadores (principalmente os das mais altas Cortes, nas quais não há espaço para rediscussão probatória) fizessem uma triagem daqueles casos que, efetivamente, seriam verdadeiros e graves problemas jurídicos, que haveriam de ser solucionados, inclusive objetivando efeito demonstrativo e paradigmático, deixando se lado outros casos mais banais, principalmente os economicamente insignificantes. ${ }^{312}$

\footnotetext{
${ }^{310}$ ALVIM NETO, José Manoel Arruda. op. cit., sendo o itálico do original. Vide, também, p. 82-83, inclusive a nota de rodapé 73, na qual esse Autor, abordando a questão da interpretação dos conceitos jurídicos vagos, sustenta que, referentemente à "atividade jurisdicional, a existência de normas vagas, e, em virtude disto, conferidoras de maior poder aos juízes, em certa escala, faz desaparecer a absoluta vinculação do juiz a regras rigidamente preestabelecidas do seu agir." E conclui: "O maior poder do juiz habilita-o a recolher de um complexo fático, o que tem por decisivo e relevante. Para que isso ocorra necessário é que, em determinados setores do Direito, existam regras capazes de viabilizar e legitimar esse método de agir."

${ }^{311}$ Id. Ibid., p. 14, sendo o itálico do original.

${ }^{312}$ ALVIM NETO, José Manoel Arruda. op. cit., p. 41, particularmente a nota de rodapé 15, onde o Autor invoca secular exemplo alemão, segundo o qual o recurso de revisão do Código de Processo Civil nasceu consciente de que "pequenos prejuízos haveriam de ser afastados do seu âmbito de possível tutela." À fl. 101 o Autor reporta-se aos arts. 546 e 554 do Código de Processo Civil Alemão (na forma anterior à reforma de 2002), nos quais ficava evidenciada a necessidade de se conciliarem os critérios econômico e de relevância (grundsätzlichen bedeutung): danos patrimoniais superiores a determinado valor e que envolvam questão relevante podem ter acesso ao Supremo Tribunal Alemão, podendo este recusar o apelo, se não aceitar a relevância por voto de $2 / 3$ de seus membros. No entanto, em assuntos não patrimoniais, se o Tribunal inferior vir a relevância, o Supremo não pode recusar a análise do recurso. Este critério de relevância (significação fundamental), atualmente (a. D. 2010), permanece no item 1 do art. 543 do Zivilprozessordnung (ZPO). De se notar que o item 2 alude a outra razão de admissibilidade ligada à
} 
Foi o que se deu com a relevância da questão federal, instituída como requisito para a admissão do recurso extraordinário (nas hipóteses das alíneas "a" e "d"), ao lado da natureza, espécie e valor pecuniário das causas, conforme expressa autorização constitucional da época (art. 119, $\S 1^{\circ}$, da EC 1/69). ${ }^{313}$

De fato, antes da relevância, o art. 308 do Regimento Interno do Supremo Tribunal Federal limitava-se a indicar as hipóteses em que não caberia o recurso extraordinário, salvo se houvesse ofensa à Constituição ou discrepância manifesta da jurisprudência da Corte.$^{314}$

Com a Emenda. Regimental n. ${ }^{\circ}$ 3/75, esse mesmo art. 308 também previa os casos de não cabimento, salvo se houvesse ofensa à Constituição ou relevância da questão federal, o que ficou um pouco mais restrito com a modificação regimental de outubro de 1980 (neste momento a manifesta divergência era com súmula do STF).

Certo, porém, é que não se definiu em que consistiria a relevância, isso só tendo ocorrido depois de dez anos, com a Emenda Regimental $n^{\circ} 2 / 85$, que deu nova redação aos arts. 325 e 327 do Regimento Interno daquela Corte.

A partir desse momento, a regra regimental inverteu o sinal para a admissão do recurso extraordinário, explicitamente dizendo que caberia recurso extraordinário nas hipóteses ali enumeradas e, conforme o inciso IX do art. 325, "em todos os demais feitos, quando reconhecida a relevância da questão federal”.(g.n.) $)^{315}$

De acordo com o respectivo $\S 1^{\circ}$ do art. 327 "Entende-se relevante a questão federal que, pelos reflexos na ordem jurídica e considerados os aspectos morais,

questão jurídica que abarque a evolução do direito ou a necessidade de interpretar uniformemente o preceito legal. O critério econômico não mais existe com a reforma do Código de Processo de Civil, ocorrida em 2002. DE JURE. Disponível em: <http://dejure.org/gesetze/ZPO/543.html>. Acesso em: 13 out. 2010.

${ }^{313}$ BRASIL. Emenda Constitucional n. 1, de 17 de outubro de 1969. Disponível em: <http://www.planalto.gov.br/ccivil_03/Constituicao/Emendas/Emc_anterior1988/emc01-69.htm>. Acesso em: 13 out. 2010.

${ }^{314}$ ALVIM NETO, José Manoel Arruda. op. cit., p. 163 e 181-185, estas últimas que constituem o Anexo I que traz os artigos do Regimento Interno do Supremo Tribunal que trataram do cabimento do recurso extraordinário, primeiramente sem a relevância e, depois, levando-a em conta.

${ }^{315}$ Id. Ibid., p. 184. 


\section{econômicos, políticos ou sociais da causa, exigir a apreciação do recurso extraordinário pelo Tribunal". (g.n.) $)^{316}$}

Ora, para José Manoel de Arruda Alvim Neto, a relevância da questão federal, conceituada de forma aberta e vaga, deu chance ao Supremo Tribunal Federal para apreciar causas que, a priori, em razão da natureza, espécie e valor pecuniário não comportariam admissão, mormente a partir da alteração regimental de 1985. Noutras palavras, emergiria art. $119, \S 1^{\circ}$, da EC $\mathrm{n}^{\mathrm{o}} 1 / 69$, "que todo o direito federal relevante deve ser objeto de tutela," 317 da maneira que viesse a ser definido pela Suprema Corte e o foi no antigo art. 325 do Regimento, sempre com vistas a disciplinar o recurso extraordinário e, não, para suprimi-lo pela raiz. ${ }^{318}$

Esse entendimento de que a arguição de relevância visava a permitir a admissibilidade de recurso extraordinário (“excluir a exclusão") também é compartilhado por Guilherme José Braz de Oliveira, que invoca Barbosa Moreira e dois incisivos julgamentos da época. ${ }^{319}$ Isto, portanto, a diferencia da transcendência e da repercussão geral, que têm intenção limitativa, sem ignorar, ainda, que a relevância também dizia respeito a questão federal, vale dizer, não exclusivamente constitucional (à época não havia STJ), sendo certo que ela foi regulamentada no Regimento Interno STF e, não, por lei.

Lembra, agora José Guilherme Berman que, desde a década de 1960, o Ministro Victor Nunes Leal defendia a adoção do modelo americano do writ of certiorari para solucionar a crise de acúmulo de processos no Supremo, sustentando que "a idéia de interesse público é que deveria nortear a definição do critério de relevância" (que ele

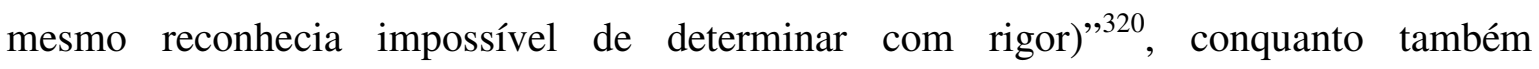
reconhecesse a dose de subjetivismo e de variabilidade de "diretivas vagas como o “interesse público”, por isso que não haveria solução ótima, mas a mais razoável.

\footnotetext{
${ }^{316}$ ALVIM NETO, José Manoel Arruda. op. cit. Veja-se a grande semelhança desta conceituação da relevância com a da transcendência do recurso de revista, feita no art. 896-A da CLT, a demonstrar os traços comuns.

${ }^{317}$ Id. Ibid., p. 26, 36, 54 e 55, nestas duas últimas, particularmente, as notas de rodapé 32 e 33, onde é feita a distinção entre o modelo fechado (analítico) de legislação e o aberto, este que permite ser dada vazão à liberdade, à sensibilidade e à criatividade do juiz ou, enfim, do aplicador da norma.

${ }^{318}$ Id. Ibid., p. 78 e 88-90, estas últimas nas quais o Autor alude ao problema da subjetividade na interpretação dos conceitos vagos em que tratem de valores, mas "não se trata de uma subjetividade descomprometida com o lastro histórico e social, e, com o esquema conjuntural", na forma como posta a definição da relevância, então feita no $\S 1^{\circ}$ do art. 327 do Regimento Interno do STF.

319 OLIVEIRA, Guilherme José Braz de. op. cit. p. 94.

${ }^{320}$ BERMAN, José Guilherme. Repercussão geral no recurso extraordinário: origens e perspectivas. Curitiba: Juruá, 2009. p. 109.
} 
Newton Doreste Baptista, teceu comentários sobre a relevância à luz da norma regimental de 1975 e, não, à luz da última de 1985. De fato, àquela altura, inexistindo definição do que seria transcendente, caberia ao "magno Tribunal, pela aplicação diuturna do direito novo, ou desse novo aspecto do direito de recorrer, assentar-lhe o exato sentido" 321 Além disso, como a decisão que viesse a admitir a transcendência não era motivada nem pública (feitas em conselho, em sessão reservada) esperava-se que aquelas que fossem acolhidas revelassem o que estaria sendo considerado questão relevante. E arremata Doreste Batista:

Poder-se-á adiantar, todavia, que será relevante a questão federal quando o interesse no seu desate seja maior fora da causa do que, propriamente, dentro dela: "Sem dúvida" - escreveram Stern e Gressmann - "o conceito de importância está relacionado com a importância das questões para o público, em contraste com a sua importância para as partes interessadas." ${ }^{322}$

Por isso, pelo alto sentido que deve ser identificado nessa noção, não poderá haver a preocupação de restringi-la ou de ampliá-la. Um critério restritivo iria, pouco e pouco, comprometendo os fins que inspiraram a Emenda, a razão mesma da idéia renovadora. Transformaria o processo da relevância num artifício de escassa imaginação. Num dique de contenção do caudal de feitos. E tão-somente. Uma exegese ampliativa, uma orientação excessivamente liberal afastaria o Tribunal colendo pelo outro extremo - de seus superiores desígnios iniciais. Em pouco a crise recrudesceria e, da Emenda Regimental n. 3, sobraria, apenas, a observação de que não passara de uma tão engenhosa quão inútil alteração regimental. ${ }^{323}$

Resta saber se a transcendência do recurso de revista, que tem como antecedente histórico a relevância da questão federal, agora no século XXI, vinte e cinco anos depois, teria assim ressurgido com o mero propósito de conter a pletora de recursos interpostos para a instância extraordinária ou, como foi anteriormente no Supremo, representava um mecanismo aberto à consideração dos julgadores para aceitar o apelo extremo, que, na rígida forma da Constituição não teria admissibilidade. ${ }^{324}$

\footnotetext{
${ }^{321}$ BAPTISTA, Newton Doreste. Da arguição de relevância no recurso extraordinário. Rio de Janeiro: Forense, 1976. p. 34. Esta é a prática construtiva que ficou obstruída no caso da transcendência do recurso de revista, exatamente porque sua regulamentação está a depender do TST.

${ }^{322}$ Esta diretriz não é inédita, bastando relembrar a tradição romana sobre a diferença entre o ius constitutionis e o ius litigatoris, tal como se mencionou supra, às fls. 11-12.

${ }^{323}$ BAPTISTA, Newton Doreste. op. cit., p. 35-37.

${ }^{324}$ ALVIM NETO, José Manoel Arruda. op. cit., p. 168, na qual, explicitamente, diz que a "relevância da causa ou da questão federal tem como função a de incluir, no rol das causas ou questões relevantes, uma causa ou questão, abstrata, mas não definida como irrelevante, atribuindo à hipótese a mesma aptidão e
} 
Todavia, como a norma da transcendência não veio dotada de exequibilidade, pois dependente da regulamentação (até agora - 2011 - inexistente), não se podem extrair conclusões da prática quotidiana, o que faz limitar sua análise crítica ao aspecto teórico e ao confronto com os resultados ocorridos com a relevância do recurso extraordinário ${ }^{325}$ e, mais recentemente, com os da repercussão geral.

Refira-se, agora, àquilo que José Manoel de Arruda Alvim chegou a mencionar (em sua aqui sempre invocada obra) como sendo o "aporte do direito comparado em hipótese similar" ${ }^{326}$, ou seja, as experiências alemã e americana, a primeira no recurso de revisão (no dizer deste Autor, equivalente ao extraordinário brasileiro) e a segunda no writ of certiorari, que foi o exemplo estrangeiro que mais de perto influiu na maneira de ser gerenciado o grande afluxo de processos que chegam até a última instância judiciária brasileira (antes com a relevância e, agora, com a repercussão geral), sendo nesse sentido os estudos feitos por Guilherme José Braz de Oliveira e José Guilherme Berman, este último que põe em relevo tensão entre o judicial review e o certiorari. ${ }^{327}$

Assim, quanto ao recurso de revisão alemão, também existe um critério de seleção ligado à significação fundamental da causa, que tem indicadores que se desdobraram em quatro vertentes, sendo a primeira ligada à defesa da unidade do direito (v. g. o caso seria relevante porque contrário a outro assim já definido), a segunda à construção do direito (v. g. "decisão recorrida contém uma interpretação difícil e muito debatida" e seu alcance será muito amplo, ou, ainda, a decisão envolve a aplicação de norma muito injusta, sendo possível uma solução outra, mesmo que praeter ou contra legem), a terceira pertinente à situação das partes litigantes (v.g. o Estado é parte ou grande número de pessoas será atingido) e a quarta diz respeito a critérios de inexpressividade do tema (v.g. questão

qualificação, de uma causa ou questão, que normalmente comporte RE. Esse ato político faz as vezes daquilo que já foi feito substancialmente por lei (minuciosa), em Regimentos anteriores, e é justamente por isto que de ato político se trata (v. ns 16 e 20, do texto)".

${ }^{325}$ ALVIM NETO, José Manoel Arruda. op. cit., p. 167, na qual o Autor trata da certa estabilidade do quadro dos casos relevantes, o exaurimento de outros por acomodação da jurisprudência antes conflitante, daí a variabilidade das hipóteses no tempo, destacando: "A casuística formada e a se formar, pelas relevâncias acolhidas, não é criada ou realizada com o fim de exaurir as hipóteses possíveis, pois o quadro existente será composto, por hipóteses razoavelmente estáveis e, outras, que a essas se irão agregando.”

${ }^{326}$ Id. Ibid., p. 96-106.

${ }^{327}$ BERMAN, José Guilherme. op. cit., p. 21 e p. 59-75. Este autor sustenta que, malgrado o sistema americano não tenha o controle concentrado de constitucionalidade, os julgamentos dos casos individuais tem grande efeito político e, portanto, mais sujeitos a críticas do que a jurisdição européia. 
isolada, já foi debatida e "não comporta maior discussão" ou, ainda, diz respeito a um caso concreto. $^{328}$

Já no que se refere ao writ of certiorari, embora não seja o único meio de acesso à Suprema Corte Norte Americana, é, no entanto, o que predomina, estando disciplinado na Rule $10^{329}$, da qual se extraem as seguintes diretrizes:

$\left.1^{\circ}\right)$ a avaliação do cabimento da revisão por intermédio do writ of certiorari não é matéria de direito; $2^{\circ}$ ) em verdade, será concedida essa revisão, em virtude de razões importantes, e, tendo em vista critério da mais pura atividade valorativa; $3^{\circ}$ ) ainda que nessa rule 19 (sic) encontrem-se as diretrizes fundamentais, em função das quais a revisão haverá de ser admitida, fica claro que, essas razões, aí referidas, conquanto hajam normalmente de ser consideradas, não têm, todavia, por fim controlar e nem mensurar a atividade da Corte. ${ }^{330}$

A estas características gerais acrescente-se a doutrina do ripeness, que consiste em negar análise de temas abstratos ou hipotéticos, que não tenham justiciabilidade, em síntese, que não estejam maduras. ${ }^{331}$

\footnotetext{
${ }^{328}$ ALVIM NETO, José Manoel Arruda. op. cit., p. 96-97. Alertava o Autor sobre a existência no sistema alemão de diversos recursos de revisão e, "nos vários diplomas que os prevêem, igualmente, o mesmo critério de relevância". Esta observação continua válida, mesmo após a reforma do processo de 2002, tal como explicado na nota de rodapé $n^{\circ} 295$.

${ }^{329}$ Rule 10. Considerations Governing Review on Writ of Certiorari

Review on a writ of certiorari is not a matter of right, but of judicial discretion. A petition for a writ of certiorari will be granted only for compelling reasons. The following, although neither controlling nor fully measuring the Court's discretion, indicate the character of the reasons the Court considers:

(a) a United States court of appeals has entered a decision in conflict with the decision of another United States court of appeals on the same important matter; has decided an important federal question in a way that conflicts with a decision by a state court of last resort; or has so far departed from the accepted and usual course of judicial proceedings, or sanctioned such a departure by a lower court, as to call for an exercise of this Court's supervisory power;

(b) a state court of last resort has decided an important federal question in a way that conflicts with the decision of another state court of last resort or of a United States court of appeals;

(c) a state court or a United States court of appeals has decided an important question of federal law that has not been, but should be, settled by this Court, or has decided an important federal question in a way that conflicts with relevant decisions of this Court.

A petition for a writ of certiorari is rarely granted when the asserted error consists of erroneous factual findings or the misapplication of a properly stated rule of law. SUPREME COURT OF THE U.S. RULES. Disponível em: <http://www.law.cornell.edu/rules/supct/10.html>. Acesso em: 20 out. 2010.

Há de se destacar pela transcrição feita que o certiorari, embora excepcionalmente, pode enveredar por matéria fática o que não se dá com os recursos de natureza extraordinária brasileiros (Súmulas 279/STF, 7/STJ e 126/TST).

${ }^{330}$ ALVIM NETO, José Manoel Arruda. op. cit., p. 98. Há erro na indicação da rule, que não é 19, mas 10.

${ }^{331}$ MENDES, Gilmar Ferreira, COELHO, Inocêncio Mártires, BRANCO, Paulo Gustavo Gonet. op. cit., p. 960. Ainda sobre a complexa forma de escolha dos processos a serem julgados pela Suprema Corte Americana, veja-se BERMAN, José Guilherme, op. cit., p. 50-54.
} 
Ressalta-se, portanto, o teor de discricionariedade de que se acham investidos os Juízes da Suprema Corte Americana (quorum de 4 votos entre 9 para aceitar a revisão e de 6 para julgamento), diferentemente do que a lei processual exige para o acesso ao Supremo Tribunal Alemão, na qual, como se viu e importa insistir, são mesclados critérios de admissão que envolvem a importância fundamental da questão trazida à Corte (grundsätzlichen bedeutung), a necessidade de exame desse tema para a evolução do direito e a uniformização do entendimento sobre a matéria (jurisprudência), dentre outras considerações. ${ }^{332}$

José Guilherme Berman detalha que a introdução do certiorari é singular na história da Suprema Corte dos Estados Unidos: uma lei de 3 de março de 1891 o criou porque,

até então, em diversas matérias, as decisões das Cotes Distritais e de Circuito não podiam ser revistas pela Suprema Corte. Com a referida lei, a Suprema Corte recebeu o poder de, através de um Writ of Certiorari, conhecer de determinado caso, ordinariamente não submetido à sua esfera de competência. ${ }^{333}$

Antes dessa lei, anota Adhemar Ferreira Maciel, a Suprema Corte Americana atuava como "tribunal de revisão", com poucos processos, mas a industrialização fez aumentar muito os recursos (mandatory appeals), daí tendo crescido a atuação discricionária, via certiorari, ao mesmo tempo em que se criavam cortes intermediárias (U.S. Court of Appeals).

Ao término da Primeira Guerra Mundial, ocorreu novo aumento da quantidade de processos, daí a consagração definitiva do certiorari como critério de definição de acesso à Suprema Corte, desde que a causa ou controvérsia, julgada em última instância pelo tribunais estaduais ou federais, se apresentasse substancialmente relevante para todo o país.

Ao longo do século XX, foram engendradas formas de organizar o julgamento, primeiro com a elaboração de discuss list ${ }^{334}$ pelo Presidente do Tribunal, para debate

\footnotetext{
${ }^{332}$ Confira-se supra, nota de rodapé 312.

${ }^{333}$ BERMAN, José Guilherme. op. cit., cit. p. 41.

${ }^{334}$ MARTINS FILHO, Ives Gandra da Silva. O critério de transcendência do recurso de revista na Justiça do Trabalho: constitucionalidade da MP n 2226/0. In: As vertentes do direito constitucional contemporâneo.
} 
reservado dos casos incluídos, e, depois, com sistema do certorari pool, pelo qual assessores qualificados dos vários gabinetes trabalhavam juntos nessa triagem dos casos, o que deu bom resultados. ${ }^{335}$

Atualmente, ainda segundo Adhemar Ferreira Maciel, os recursos obrigatórios praticamente desapareceram, prevalecendo a discricionariedade, conjugada com a relevância, ${ }^{336}$ asserção que conta com a concordância de Guilherme José Braz de Oliveira :

Em suma, nos dias de hoje, com a enorme restrição às mandatory appeals, nos termos da Rule 18 of the United States Supreme Court, o acesso ao Tribunal de cúpula do Poder Judiciário norte-americano decorre, basicamente, do julgamento dos pedidos de writ of certiorari, os quais estão sujeitos à apreciação discricionária de seus Juízes, com base no critério da relevância. ${ }^{337}$

Este último Autor esclarece que o certiorari influenciou a criação de filtros recursais em outros países, dentre os quais indica a Argentina e o Japão. ${ }^{338}$

Rio de Janeiro: América Jurídica, 2002. p. 386, onde o autor dá uma idéia da tramitação do certiorari na Suprema Corte Americana e, ainda, se refere aos critérios de sua admissão, que não são apenas jurídicos, mas políticos, como, por exemplo, "divergência na interpretação da legislação federal entre Cortes Federais de Apelação, entre Cortes Estaduais e entre estas e as Cortes Federais; desrespeito notório dos procedimentos judiciais correntes, exigindo supervisão da Suprema Corte; repercussão geral, pela sua importância, de uma determinada questão ligada à legislação federal, julgada por uma corte inferior."

${ }^{335}$ MACIEL, Adhemar Ferreira. Restrição à admissibilidade de recursos na Suprema Corte dos Estados Unidos e no Supremo Tribunal Federal do Brasil. Revista de Informação Legislativa, Brasília, ano 43, n. 170, p. 8, abr./jun. 2006.

${ }^{336}$ Id. Ibid., p. 9. Interessante o desenvolvimento histórico do mais importante recurso para a Suprema Corte Americana, segundo a explanação deste Autor. Com efeito, pelo Judiciary Act de 1789, a Constituição Americana previu um "recurso judicial contra as decisões finais dos tribunais estaduais de mais alta instância quando se questionasse a validade de lei federal ou de tratado, ou quando tais decisões fossem "repugnant to the constitution, treaties, or laws of the United States". O nome desse meio impugnativo era "writ of error" (Cf. COMMAGER, 1958, p. 154) O recorrente, ao interpor o recurso, alegava error in procedendo ou error in judicando, isto é, errores of the law (erros de direito) da decisão recorrida, a fim de que a Suprema Corte federal anulasse (cassasse) ou reformasse o julgado." Este Autor diz que o writ of error "foi a origem de nosso "recurso extraordinário" (p. 10), ponto controvertido, porém, que vem mencionado por José Guilherme Berman (op. cit. p. 95), que alude ao direito português. No entanto, a influência do Judiciary Act no início da República e na atuação do Supremo Tribunal Federal, também reconhecida por Estêvão Mallet (op. cit. p. 27), antes de conflitar, reforça a peculiaridade dos recursos extraordinários (unidade e autoridade do direito federal, assim como na sua interpretação, para coibir injustiça ou nulidade manifestas, tudo isso que já era da tradição romana e da lusitana, tal como explanado no Capítulo I. Aliás, já se disse que Osmar Mendes Paixão Côrtes dá grande ênfase à influência norteamericana para o surgimento do recurso extraordinário, vinculando-o ao referido writ of error do direito anglo-saxão (op. cit. p. 101-186), no que coincide(e muito) com a evolução romana e ibérica aqui mencionadas, mormente porque dentro daquele longo processo de concentração de poder nas mãos do Rei e, por sua delegação, na sua Curia Regis, após a conquista normanda e sua consolidação (vide, p. 116).

${ }^{337}$ OLIVEIRA, Guilherme José Braz de, op. cit. p. 54

${ }^{338}$ Id. op. cit. p. 153-154, aonde o Autor proporciona uma rápida visão do que acontece com os recursos extraordinários nesses países e na Alemanha, citando artigos de Nelson Nery e Barbosa Moreira. 
Não obstante este sedutor modelo norte-americano do petition for writ of certiorari tenha angariado muitos simpatizantes porque, reconheça-se, dá uma solução positiva ou negativa, não restam dúvidas de que a alta discricionariedade que o impregna ${ }^{339}$ (apesar de sempre ser destacada a grande importância do caso e, às vezes, a necessidade de uma tutela de urgência - deviation from normal appellate practice and to require immediate determination in this Court -), tudo isso põe em relevo as diferenças entre os sistemas jurídicos europeu (romano-germânico) e o anglo-saxão: no primeiro, predomina a legislação escrita e, no segundo, a força do precedente jurisprudencial, sintetizado no princípio do stare decisis et non quieta movere, mencionado por Aliomar Baleeiro, que se valeu de pronunciamento do Justice Douglas, segundo o qual "assegura uniformidade e continuidade do Direito, permite aos homens o arranjo de seus negócios e atividades em base da confiança, expulsa das relações jurídicas o capricho e garante estabilidade ao corpo social, como um laço entre o futuro e o passado." 340

Assim sendo, à parte o incremento do prestígio que no Brasil, de fato, há de ser dado à jurisprudência (e o foi, em boa medida, com a EC 45/04, mas não repercutiu, ainda, nos Tribunais Superiores), cabe a advertência de Estêvão Mallet que, invocando Barbosa Moreira, prescreve cautela na importação de soluções estrangeiras, "tendo em conta as peculiaridades por vezes presentes nos diferentes sistemas jurídicos." ${ }^{341}$

Uma coisa, porém, pode ser extraída da experiência estrangeira aqui invocada, ainda que rapidamente: o papel da Suprema Corte é distinto daquele dos Tribunais intermediários; o acesso a um terceiro grau de jurisdição não é incondicional e pode ser excepcional; depois que já ocorreu julgamento em dois graus de jurisdição, não há como

\footnotetext{
${ }^{339}$ Evidencia essa alta discricionariedade a Rule 11 permitir, por meio de writ of certiori, intervenção em caso que ainda não foi julgado na corte inferior: Rule 11. Certiorari to a United States Court of Appeals before Judgment - A petition for a writ of certiorari to review a case pending in a United States court of appeals, before judgment is entered in that court, will be granted only upon a showing that the case is of such imperative public importance as to justify deviation from normal appellate practice and to require immediate determination in this Court. See 28 U. S. C. $\$ 2101($ e). SUPREME COURT OF THE U.S. RULES. Disponível em: <http://www.law.cornell.edu/rules/supct/10.html>. Acesso em: 20 out. 2010.

${ }^{340}$ BALEEIRO, Aliomar. O Supremo Tribunal Federal, esse outro desconhecido. Rio de Janeiro: Forense, 1968, p. 126, Apud BAPTISTA, Newton Doreste. op. cit., p. 24.

${ }^{341}$ MALLET, Estêvão. Celeridade da prestação jurisdicional e seleção das causas a serem julgadas pelos Tribunais Superiores. In: Direito e processo do trabalho em transformação. Rio de Janeiro: Elsevier, 2007. p. 113-126.
} 
reconhecer que o acesso ao Tribunal Superior ou à Suprema Corte represente afronta ao devido processo legal. ${ }^{342}$

E, conquanto tenha se referido ao modelo norte-americano, cabe a conclusão de José Guilherme Berman no sentido de que a

Suprema Corte possui uma missão que a diferencia dos demais tribunais: não se trata de uma instância de revisão, que aprecia qualquer matéria em que esteja envolvido um direito individual, mas sim de uma Corte que escolhe julgar apenas os casos cuja importância seja destacada e cuja repercussão vá muito além das partes envolvidas no feito, alcançando, de fato, toda a sociedade norte-americana. ${ }^{343}$

Este é o desenho que se quer emprestar ao Supremo Tribunal Federal, quando a ele se reserva a análise dos casos em que se demonstre a repercussão geral, situação que difere, em grande medida, dos Tribunais Superiores e, portanto, para os quais, em princípio, não devem ser aplicadas as regras que pautam a atuação do verdadeiro e efetivo Tribunal de Cúpula do Judiciário. ${ }^{344}$

Exatamente, aqui, portanto, cabe dedicar algumas linhas à repercussão geral, a começar pela sua gênese no Congresso Nacional, pois é disso, precisamente, que se sentiu e se sente falta no trato da relevância do recurso de revista, vale dizer, sua discussão e deliberação perante os representantes do povo brasileiro, o que ensejou a repulsa e o descrédito, afora, evidentemente, as peculiaridades do processo do trabalho.

No ano de 2004, após a aprovação da Emenda Constitucional n. ${ }^{\circ} 45$, os Presidentes da República, do Supremo Tribunal Federal, do Senado Federal e da Câmara dos Deputados celebraram o que se denominou "I Pacto pelo Judiciário - Pacto de Estado em favor de um Judiciário mais rápido e republicano". Preocupavam-se os Chefes dos Poderes Constituídos com a morosidade dos processos judiciais e com a crise de eficácia

\footnotetext{
${ }^{342}$ BERMAN, José Guilherme. op. cit., p. 44-45, quando trata da possível tensão entre o sistema do certiorari e o do judicial review, por isso aludindo ao papel político da Suprema Corte, "ultrapassando a esfera do puramente jurídico". Tenha-se em conta, todavia, que o controle de constitucionalidade norte-americano é difuso e não há a forma concentrada, tal como é da tradição européia e da brasileira.

${ }^{343}$ Id. op. cit., p. 40.

${ }^{344}$ MARTINS FILHO, Ives Gandra da Silva. op. cit., p. 389-393, evoca os exemplos exitosos de utilização filtros recursais na Corte Constitucional Alemã (contenção dos recursos intranscendentes), na Suprema Corte Argentina(art. 280 do Código Procesal Civil y Comercial de la Nación- certiorari criollo) e no Tribunal Constitucional Espanhol (Lei Orgânica do Tribunal Constitucional, art.50). Como se vê, trata-se dos tribunais de cúpula daqueles países, o que não se dá com o TST e o STJ.
} 
das decisões jurisdicionais, a ensejar consequências como o descrédito do regime democrático, a generalização da impunidade e da inadimplência, com o consequente entrave em investimentos, tudo a refletir-se no desenvolvimento nacional. ${ }^{345}$

No âmbito deste Pacto, enfrentou-se o problema da reforma do sistema recursal, tanto na seara cível, como na seara trabalhista. Foi mencionada a necessidade de agilização de procedimentos, de simplificação de julgamentos e de manutenção, nesse novo ordenamento processual, das garantias e direitos fundamentais. ${ }^{346}$

No espírito do Pacto de Estado, a Comissão Mista Especial do Congresso Nacional para Regulamentação da Reforma do Poder Judiciário e Promoção da Reforma Processual elaborou, em 13/12/2005, um relatório indicando os principais tópicos dessa agenda. Neste relatório, apontaram-se problemas como a tutela do direito fundamental à razoável duração do processo, nos termos do artigo $5^{\circ}$, inciso LXXVIII, da Constituição Federal, a racionalização do acesso aos tribunais superiores e a necessidade de implementação da repercussão geral do recurso extraordinário ${ }^{347}$.

Sobre esse tema, em especial, indica o relatório a necessidade de vir o STF a pronunciar-se apenas sobre "as grandes questões do país". Pugna ainda por uma interpretação elástica do termo "repercussão geral", para que abarque "questões econômicas, políticas e sociais, (...) mantendo-se sempre a necessidade de transcendência" ${ }^{348}$.

Em 23/01/2006, como fruto do trabalho desenvolvido até então, a Comissão Mista Especial do Congresso Nacional para Regulamentação da Reforma do Poder Judiciário e Promoção da Reforma Processual apresentou ao Senado Nacional o Projeto de Lei n. ${ }^{\circ}$ 12/2006, tratando da regulamentação do artigo 102, $\S 3^{\circ}$, da Constituição Federal. Este Projeto, normativizando essa exigência para interposição do recurso extraordinário, foi

\footnotetext{
${ }^{345}$ Pacto pelo Judiciário - Pacto de Estado em favor de um Judiciário mais rápido e republicano. MINISTÉRIO DA JUSTIÇA. Reforma do Judiciário. Pacto Republicano. Disponível em: <http://portal.mj.gov.br/data/Pages/MJ8E452D90ITEMID87257F2711D34EE1930A4DC33A8DF216PTB RIE.htm>. Acesso em: 01 dez 2010.

${ }^{346}$ Id. Ibid.

${ }^{347}$ Relatório n. ${ }^{\circ}$ 01/2006, de 13/12/2005, da Comissão Mista Especial para Reforma do Poder Judiciário, p. 44. SENADO FEDERAL. Portal Atividade Legislativa. Comissões Mistas. Disponível em: <http://www.senado.gov.br/atividade/materia/getPDF.asp?t=40131>. Acesso em: 01 dez. 2010.

${ }^{348}$ Relatório n..$^{\circ}$ 01/2006, de 13/12/2005, da Comissão Mista Especial para Reforma do Poder Judiciário, p. 44. Disponível em: <http://www.senado.gov.br/atividade/materia/getPDF.asp?t=40131>. Acesso em: 01 dez. 2010, p. 44.
} 
analisado pela Comissão de Constituição, Justiça e Cidadania do Senado, do que resultou um primeiro parecer, datado de 01/02/2006. ${ }^{349}$

Neste primeiro documento, ressoa a preocupação do legislador com o papel conferido à Suprema Corte e às decisões por esta prolatadas. A repercussão geral permitiria ao STF a eleição de temas relevantes no âmbito jurídico, com efeitos nas áreas política, econômica e social, deixando a Corte, desse modo, de atuar como mera terceira ou quarta instância recursal. Sobre a relevância das matérias a ensejarem o reconhecimento da repercussão geral, cumpre mencionar o artigo $6^{\circ}$ do projeto original, que assim previa:

Art. $6^{o}$. Sem prejuizo de outras reconhecidas pelo Supremo Tribunal Federal, possuem repercussão geral as causas:

I - que contenham julgamento divergente da súmula ou jurisprudência dominante do Supremo Tribunal Federal;

II - relativas à nacionalidade e aos direitos políticos;

III - que discutam direitos ou interesses difusos;

IV - relativas ao exercício de mandato eletivo federal, estadual ou municipal, bem como às garantias e prerrogativas da Magistratura, do Ministério Público, da Defensoria Pública e da advocacia;

$V$ - relativas a crimes de genocídio, terrorismo, contra a humanidade, contra o sistema financeiro, de lavagem de dinheiro, praticados por organizações criminosas, bem assim outros cujo potencial ofensivo à sociedade possa justificar tal caracterização.

Apesar de o rol não ser taxativo, entendeu a Comissão de Constituição, Justiça e Cidadania ser mais apropriado deixar ao próprio STF, por meio de seu regimento interno, a fixação de critérios para definição do que seja a repercussão geral. De qualquer modo, já patente neste primeiro parecer a preocupação em trazer para o Supremo apenas "questões que possuam efetiva e ampla repercussão no tecido social brasileiro, seja por um vetor político, econômico ou social.",350

\footnotetext{
${ }^{349}$ SENADO FEDERAL. Parecer n. 75, de 2006. Disponível em: <http://www.senado.gov.br/atividade/materia/getPDF.asp?t=40132>. Acesso em: 01 dez. 2010.

${ }^{350}$ Id. Ibid.
} 
Enviado o projeto à Câmara dos Deputados, foi elaborado parecer pela Comissão de Constituição e Justiça e de Cidadania. ${ }^{351}$ Afora os aspectos destacados pelo parecer anteriormente emitido pela comissão congênere do Senado Federal, observou a Câmara o paralelismo entre a repercussão geral e a arguição de relevância, prevista no Regimento Interno do Supremo Tribunal Federal como limite à interposição de recurso extraordinário por autorização do texto constitucional de 1969.

Entretanto, julgou a Câmara dos Deputados serem de diferente natureza os institutos supracitados, conquanto semelhantes. Em oposição ao caráter antidemocrático da arguição de relevância, demonstrou-se a legitimidade da repercussão geral com base na necessária seleção, para apreciação pelo Supremo, de causas paradigmáticas sob os aspectos político, econômico, social ou jurídico.

Dos debates do Poder Legislativo, associados aos imperativos do Pacto de Estado, emanou a Lei n. ${ }^{\circ}$ 11.418/2006, publicada em 20/12/2006, regulando de forma definitiva a repercussão geral no âmbito do Supremo Tribunal Federal.

A repercussão geral, de fato, assemelha-se à antiga argüição de relevância, que vigorou até a promulgação da Constituição de 1988, relembre-se, instituída no bojo do chamado "Pacote de Abril", de 1977, com viés reputado antidemocrático, seja pela forma de regulamentação e julgamento, seja pela própria época em que surgira ("pacote de abril").

Luiz Guilherme Marinoni,, porém, sustenta que a relevância e a repercussão geral não se confundem:

Enquanto ao primeira funcionava como instituto que visava a possibilitar o conhecimento deste ou daquele recurso extraordinário a prori incabível, funcionando como um instituto com característica central inclusiva, a repercussão geral visa a excluir do conhecimento do STF controvérsias que assim não se caracterizem. ${ }^{352}$

\footnotetext{
${ }^{351}$ Parecer do Relator, Dep. Odair Cunha, no PL n. ${ }^{\circ}$ 6.648/2006 - Comissão de Constituição e Justiça e de Cidadania da Câmara dos Deputados. CÂMARA DOS DEPUTADOS. Comissão de Justiça e Cidadania. Projeto de Lei $n$. 6.648, de 2006. Disponível em: <http://www.camara.gov.br/sileg/integras/399380.pdf>. Acesso em: $01 \mathrm{dez} .2010$.

${ }^{352}$ MARINONI, Luiz Guilherme. O filtro processual do STF. RT Informa, São Paulo, ano 9, ed. espec. n. 52, p. 5, nov. 2007/abr. 2008.
} 
A arguição de relevância, inegavelmente, apresentava-se como filtro de acesso ao STF, que triava os recursos extraordinários que não ostentassem relevância jurídica, política, social ou econômica, ${ }^{353}$ sendo certo que, àquela época (final dos setenta) e hoje em dia, avassalador é o número de processos que chegam ao STF, tal como o expôs Bruno Dantas, “consultor-geral do Senado Federal, responsável pela chefia da equipe técnica que redigiu e discutiu no Congresso Nacional o projeto de lei que buscava soluções para o excesso de demanda no STF":

Dados estatísticos compilados no Banco Nacional de Dados do Poder Judiciário revelavam uma situação insustentável na mais alta Corte nacional: a obrigação imposta ao Tribunal de se debruçar sobre cerca de 100 mil processos ao ano acabava levando à dissipação de tempo e energia que podem e devem ser dedicados ao exame das grandes causas nacionais.

Ivo Dantas comentou essa necessidade de contenção do acesso aos Tribunais

Superiores, observando o que se dera com a relevância:

Recentemente, e ainda com relação ao tema da relevância, OSMAR MENDES PAIXÃO CÔRTES (Recurso Extraordinário - Origem e Desenvolvimento no Direito Brasileiro) faz interessante observação ao afirmar que "a questão federal era tida como relevante, nos termos do art. 237 do RISTF, quando, pelos seus reflexos na ordem jurídica, e considerados os aspectos morais, econômicos, políticos ou sociais da causa, exigisse a apreciação do recurso extraordinário. Era examinada na sessão do Conselho, no Supremo Tribunal Federal, previamente ao recurso propriamente dito. Rodolfo de Camargo Mancuso - prossegue PAIXÃO CÔRTES - bem destaca que muito se questionou sobre a natureza jurídica da argüição de relevância, estando o tema, todavia, pacificado, na doutrina e jurisprudência, no sentido de que 'não se tratava de recurso, e sim de um expediente que - pondo em realce a importância jurídica, social e econômica da matéria versada no recurso extraordinário - buscava obter o acesso desse apelo extremo no Supremo Tribunal Federal, nas hipóteses em princípio excluídas de seu âmbito'. Muitas críticas foram feitas à argüição de relevância, que poderia levar à absoluta discricionariedade do Supremo Tribunal Federal na apreciação do recurso extraordinário. E, de fato, dependendo da regulamentação dada pelo Supremo Tribunal Federal, havia risco de redução considerável das hipóteses de cabimento do recurso e esvaziamento da sua tradicional função relacionada à manutenção do federalismo. Mas consoante já anotado, um maior risco poderia advir do excesso de processos levados à apreciação da Suprema Corte. Nesse sentido, Rodolfo de Camargo

\footnotetext{
${ }^{353}$ THEODORO JUNIOR, Humberto; NUNES, Dierle; BAHIA, Alexandre. Litigiosidade em massa e repercussão geral no recurso extraordinário. Revista de Processo, São Paulo, ano 34, n. 177, p. 24 , nov. 2009.

${ }^{354}$ MARINONI, Luiz Guilherme. O filtro processual do STF, cit., p. 4.
} 
Mancuso fala da necessidade de filtragem dos processos: 'De todo modo, parece indisputável que algum tipo de controle, filtro ou filtragem há de existir para o acesso às Cortes Superiores, quanto mais não seja ante a evidente desproporção entre o número de seus membros e o volume de processos que, de outro modo, ali aportariam, sem um critério distintivo ou regulador; outrossim, a singela alternativa do aumento do número de julgadores, sobre não resolver o problema, acarretaria a indesejável macrocefalia da estrutura do Poder Judiciário, de per si já bastante avantajada', conclui MANCUSO em citação trazida por PAIXÃO CÔRTES. ${ }^{355}$

Uma diferença substancial entre o modelo da argüição de relevância e o da repercussão geral é que, no primeiro caso, a decisão do tribunal, sob o pálio da EC 1/69, dava-se em sessão secreta, em órgão $a d$ hoc, i. e. Conselho (nem Turmas nem Plenário) sem necessidade de fundamentação, por isso decisão política, o que, evidentemente, desde a Carta Constitucional de 1988 vai de encontro à regra do inciso IX do art. 93, em especial após o advento da EC 45/04.

Se a argüição de relevância é o ancestral mais remoto da repercussão geral, o precedente mais próximo desta é, evidentemente, a própria transcendência ${ }^{356}$, incorporada ao ordenamento jurídico pela Medida Provisória n 2.226, de 04 de setembro de 2001. Justificada está, portanto, a compreensão conjunta dos dois institutos que, no mínimo, possuem a mesma motivação e ostentam conteúdo semelhante.

Ivo Dantas ressalva que

quer se use a expressão Arguição de Relevância, como o fez o texto constitucional de 1969, em seu art. 119 com a redação dada pela EC 7/77, quer se use o vocábulo Transcendência (CLT) ou ainda repercussão geral das questões constitucionais discutidas no caso, vale que se traga à colação a lição de ALFREDO BUZAID, citado por RAUL ARMANDO MENDES, quando definindo Argüição de Relevância, ensinava: "Convém salientar, antes de mais nada, que 'a argüição de relevância não é outro recurso, que se deva apresentar em separado. Ao contrário, integra o recurso extraordinário, é parte dele e só com ele pode ser deduzida. Apenas por medida de ordem pública - o fácil e pronto de seus fundamentos - exige o Regimento o destaque, mas na mesma petição, onde ocupará capítulo específico'.

\footnotetext{
${ }^{355}$ DANTAS, Ivo. Da repercussão geral como pressuposto específico e como filtro ou barreira de qualificação do recurso extraordinário. Disponível em: <http://jusvi.com/artigos/40811>. Acesso em: 22 nov. 2010.

${ }^{356}$ É o que admite Guilherme José Braz de Oliveira em sua dissertação já citada, conforme se vê às fls. 133-143.
} 
A relevância da questão federal - continua BUZAID - é um conceito novo no direito brasileiro, que a doutrina está elaborando cuidadosamente, posto que sem contar com os valiosos subsídios do Supremo Tribunal Federal, onde é julgada em sessão do Conselho, de cuja ata 'constará apenas a relação das argüições não conhecidas, bem como das acolhidas e rejeitadas' (Regimento Interno, art. 328, VIII). Doreste Baptista observa que 'será relevante a questão federal quando o interesse no seu desate seja maior fora da causa do que propriamente dentro dela'. O eminente Min. Victor Nunes Leal - prossegue - a quem cabe o mérito da criação desse instrumento para reduzir os encargos do Supremo Tribunal Federal, depois de assinalar as dificuldades de uma definição, observou: 'Antes de tudo, a relevância para esse efeito, será apurada especialmente do ponto de vista do interesse público" conclui. ${ }^{357}$

Parece claro, portanto, que a repercussão geral, tal qual as congêneres medidas da transcendência e dos processos repetitivos, encaixa-se no perfil técnico dos denominados "processos teste" (test claims), nos quais, para a resolução dos litígios em massa, o tribunal superior não haveria de julgar todos e individualmente os recursos que lhe fossem apresentados, mas, sim, apenas a tese abordada naqueles tidos como representativos da discussão jurídica. ${ }^{358}$

A estratégia adotada está em consonância com a idéia recorrente de que o papel dos tribunais superiores, em especial o das Cortes Supremas, seria meramente garantir a uniformidade da aplicação da norma e, não, a atuação como juízo de terceira instância. ${ }^{359}$

Ivo Dantas, chama a atenção para o caráter político da aplicação do critério da repercussão geral:

Em última análise, há de ser considerado que o mencionado filtro tem uma natureza política, como entende JOSÉ MANOEL DE ARRUDA ALVIM, aqui trazido em citação de ATHOS GUSMÃO: "A respeito do tema escreveu José Manoel de Arruda Alvim que a expressão 'repercussão geral' significa praticamente a colocação de um filtro, ou um divisor de águas em relação ao cabimento do recurso extraordinário,

\footnotetext{
${ }^{357}$ OLIVEIRA, Guilherme José Braz de. op. cit.

${ }^{358}$ THEODORO JUNIOR, Humberto; NUNES, Dierle; BAHIA, Alexandre. op. cit., p. 22-23.

${ }^{359}$ Humberto Theodoro Júnior, Dierle Nunes e Alexandre Bahia lembram, no entanto, o risco de se estabelecer um paralelo automático entre essa idéia, recorrente no âmbito dos países europeus, e a realidade brasileira. Isso porque não contamos, no Brasil, com tribunais de cassação, mas com tribunais que realizam o rejulgamento das causas. Na tradição das Cortes de Cassação européias, o tribunal, anulando a decisão, não julga, mas promove o reenvio da causa a outro órgão jurisdicional que fará a aplicação da tese jurídica exposta pela Corte, em face das peculiaridades do caso. Em suma, o recurso europeu de cassação não é, por si só, um empecilho ao reexame do quadro fático do processo. In THEODORO JUNIOR, Humberto; NUNES, Dierle; BAHIA, Alexandre. op. cit., p. 13-14.
} 
deixando de merecer julgamento os recursos não dotados deste atributo, ainda que formal e substancialmente pudessem ser aptos à admissão e ao julgamento. Refere o eminente processualista, com a costumeira propriedade, que o novo instituto se coloca como filtro de caráter político prévio à admissão, propriamente dita, do recurso extraordinário, e assim deverá permitir a admissão de recursos com a flexibilidade desejável, descartando aqueles recursos 'que não mais tenham razão alguma de ser, senão uma insistência socialmente não desejável do recorrente, permeada por um animus lotérico". Por esta razão, observou LUIZ FUX que "o modelo no qual se inspirou o nosso legislador não é o europeu, como em geral verifica-se nos institutos processuais. Nesse particular, a nossa fonte é norte-americana é precisamente o judiciary act de 1789, que instituiu a competência da Corte Suprema para apreciar recursos de decisões 'locais' que violassem a ordem central." 360

Recorde-se que a repercussão geral foi introduzida no ordenamento jurídico brasileiro por meio da EC 45/04, que acrescentou o $\S 3^{\circ}$ ao artigo 102 da Constituição Federal, in verbis: "no recurso extraordinário o recorrente deverá demonstrar a repercussão geral das questões constitucionais discutidas no caso, nos termos da lei, a fim de que o Tribunal examine a admissão do recurso, somente podendo recusá-lo pela manifestação de dois terços de seus membros".

E, a despeito da norma constitucional encontrar-se em vigor desde o final de 2004, publicada que foi em 31 de dezembro, condicionava-se a sua eficácia à edição de lei regulamentadora da matéria, com o intuito de detalhar os contornos do respectivo procedimento, o que, repita-se, não se deu com a transcendência.

Os primeiros esboços de anteprojeto, que, afinal, vieram a resultar na Lei 11.418 de 19.12.2006, foram debatidos nas VI Jornadas Brasileiras de Direito Processual Civil, ocorridas entre 11 e 14 de outubro de 2005, em Brasília, com o aval da Consultoria Jurídica do Senado Federal e, ao que consta, dos Ministros do E. STF Gilmar Mendes e Cezar Peluso, sendo relatado por José Rogério Cruz e Tucci. ${ }^{361}$

A referida lei inseriu no Código de Processo Civil os artigos 543-A e 543-B, cuja redação é a seguinte:

Art. 543-A. O Supremo Tribunal Federal, em decisão irrecorrível, não conhecerá do recurso extraordinário, quando a questão constitucional nele

\footnotetext{
${ }^{360}$ DANTAS, Ivo. op. cit.

${ }^{361}$ CRUZ E TUCCI, José Rogério. Anotações sobre a repercussão geral como pressuposto de admissibilidade do recurso extraordinário (Lei 11.418/2006). Revista de Processo, São Paulo, ano 32, n. 145, mar. 2007.
} 
versada não oferecer repercussão geral, nos termos deste artigo. (Incluído pela Lei $\mathrm{n}^{\mathrm{o}}$ 11.418, de 2006).

$\S 1$ 1o Para efeito da repercussão geral, será considerada a existência, ou não, de questões relevantes do ponto de vista econômico, político, social ou jurídico, que ultrapassem os interesses subjetivos da causa. (Incluído pela Lei $\mathrm{n}^{\circ} 11.418$, de 2006).

$\S 20$ O recorrente deverá demonstrar, em preliminar do recurso, para apreciação exclusiva do Supremo Tribunal Federal, a existência da repercussão geral. (Incluído pela Lei no 11.418, de 2006).

§ 3o Haverá repercussão geral sempre que o recurso impugnar decisão contrária a súmula ou jurisprudência dominante do Tribunal. (Incluído pela Lei $\mathrm{n}^{\circ} 11.418$, de 2006).

$\S 4$ o Se a Turma decidir pela existência da repercussão geral por, no mínimo, 4 (quatro) votos, ficará dispensada a remessa do recurso ao Plenário. (Incluído pela Lei no 11.418 , de 2006).

§ 5o Negada a existência da repercussão geral, a decisão valerá para todos os recursos sobre matéria idêntica, que serão indeferidos liminarmente, salvo revisão da tese, tudo nos termos do Regimento Interno do Supremo Tribunal Federal. (Incluído pela Lei no 11.418, de 2006).

§ 6o O Relator poderá admitir, na análise da repercussão geral, a manifestação de terceiros, subscrita por procurador habilitado, nos termos do Regimento Interno do Supremo Tribunal Federal. (Incluído pela Lei ${ }^{\circ}$ 11.418, de 2006).

§ 7o A Súmula da decisão sobre a repercussão geral constará de ata, que será publicada no Diário Oficial e valerá como acórdão. (Incluído pela Lei ${ }^{\circ}$ 11.418, de 2006).

Art. 543-B. Quando houver multiplicidade de recursos com fundamento em idêntica controvérsia, a análise da repercussão geral será processada nos termos do Regimento Interno do Supremo Tribunal Federal, observado o disposto neste artigo. (Incluído pela Lei $\mathrm{n}^{\mathrm{o}} 11.418$, de 2006).

$\S$ 1o Caberá ao Tribunal de origem selecionar um ou mais recursos representativos da controvérsia e encaminhá-los ao Supremo Tribunal Federal, sobrestando os demais até o pronunciamento definitivo da Corte. (Incluído pela Lei $\mathrm{n}^{\circ} 11.418$, de 2006).

$\S 2$ o Negada a existência de repercussão geral, os recursos sobrestados considerar-se-ão automaticamente não admitidos. (Incluído pela Lei $\mathrm{n}^{\circ}$ 11.418, de 2006).

§ 3o Julgado o mérito do recurso extraordinário, os recursos sobrestados serão apreciados pelos Tribunais, Turmas de Uniformização ou Turmas Recursais, que poderão declará-los prejudicados ou retratar-se. (Incluído pela Lei no 11.418, de 2006).” 
$\S$ 4o Mantida a decisão e admitido o recurso, poderá o Supremo Tribunal Federal, nos termos do Regimento Interno, cassar ou reformar, liminarmente, o acórdão contrário à orientação firmada. (Incluído pela Lei $\mathrm{n}^{\mathrm{o}}$ 11.418, de 2006).

$\S 50$ O Regimento Interno do Supremo Tribunal Federal disporá sobre as atribuições dos Ministros, das Turmas e de outros órgãos, na análise da repercussão geral. (Incluído pela Lei $n^{\circ} 11.418$, de 2006).

Destaca-se, à primeira vista, que o $\S 1^{\circ}$ do art. 543-A limitou-se a considerar, como dotada de repercussão geral, a questão relevante do ponto de vista econômico, político, social ou jurídico, que venha a suplantar o interesse individual dos litigantes.

Deixou o legislador de detalhar essas conceituações de forma específica, mantendo o caráter de "conceito jurídico indeterminado", tal qual fez o constituinte derivado, que atribuiu ao julgador a incumbência de aplicá-lo a partir da análise das particularidades do caso concreto. ${ }^{362}$

$\mathrm{O} \S 2^{\circ}$ do art. 543-A estabelece que a demonstração da existência da repercussão geral há de constar de preliminar argüida pelo recorrente. No caso de a decisão impugnada afrontar Súmula ou jurisprudência dominante do E. STF, pressupõe-se, nos termos do $\S 3^{\circ}$ do art. 543-A, a existência de repercussão geral, devendo o recorrente demonstrar essa circunstância.

A apreciação da existência do requisito é de competência exclusiva do STF, nos termos do $\S 3^{\circ}$ do art. 102 da Constituição Federal, que preceitua que o recurso somente será recusado, em razão da ausência de repercussão geral, por dois terços dos Ministros.

$\mathrm{O}$ art. $3^{\circ}$ da Lei 11.418/06 previu que a necessária regulamentação do procedimento relativo à repercussão geral seria feito por meio do Regimento Interno do STF, o que se deu com as Emendas Regimentais 21 (de 30.04.2007), 22 (de 30.11.2007) e 23 (11.03.2008).

Entre as novidades da regulamentação prática, destaca-se a formação do "Pleno Virtual” para a apreciação da repercussão geral, que consiste na submissão, pelo Relator,

\footnotetext{
${ }^{362}$ BARBOSA MOREIRA, José Carlos. A redação da Emenda Constitucional n. 45 (reforma da justiça). In: Revista Forense 378/44, 2005 apud CRUZ E TUCCI, José Rogério. Anotações sobre a repercussão geral como pressuposto de admissibilidade do recurso extraordinário (Lei 11.418/2006), cit., p. 155.
} 
de cópia de sua manifestação aos demais Ministros, os quais terão 20 dias para fazer o mesmo. Se não houver manifestações suficientes para a recusa do recurso (repita-se 2/3), considera-se existente a repercussão geral.

No dia 30.04.2008, o E. STF julgou os primeiros casos em que apreciou a repercussão geral, a saber, RE 565.714 e RE 570.177. ${ }^{363}$

Quanto ao momento para apreciação da repercussão geral, a Lei 11.418/06 não o especificou, o que tem gerado algum dissenso doutrinário, e até, causa certa perplexidade em face da utilidade e aproveitamento dos atos processuais. Arruda Alvim, citado por José Rogério Cruz e Tucci, sustenta que :

o exame da repercussão geral deverá ser prévio à admissibilidade propriamente dita, ou à admissibilidade em sentido técnico, como assunto preliminar, já quando e dentro do âmbito do julgamento do recurso. (...) Mas essa deliberação preliminar é inconfundível com a admissibilidade propriamente dita (com a verificação do cabimento/enquadramento do recurso nas hipóteses do art. 102 da CF e legislação ordinária), a qual é juízo preambular já dentro do procedimento do julgamento do recurso. ${ }^{364}$

Já Élvio Ferreira Sartório e Flávio Cheim Jorge, também citados nesse mesmo artigo, defendem, em sentido oposto, que o requisito da repercussão geral deve ser analisado pelo STF só depois da prévia avaliação do relator a respeito da presença dos requisitos extrínsecos, intrínsecos e específicos de admissibilidade do recurso extraordinário. Num primeiro exame, será incontornável examinar, monocraticamente, se o recurso é admissível ou, não, para, em caso positivo, posteriormente, submeter (virtualmente) o debate acerca da existência da repercussão geral.

Em verdade, seria inútil e desgastante que o STF agisse de outra forma, pois correria o risco de reconhecer a existência da repercussão geral e, ao depois, não conhecer o recurso no mérito, por ausência de outro ou outros requisitos de admissibilidade. ${ }^{365}$

\footnotetext{
${ }^{363}$ THEODORO JUNIOR, Humberto; NUNES, Dierle; BAHIA, Alexandre. op. cit., p. 30-31.

${ }^{364}$ ARRUDA ALVIM, J.M. de. A EC n. 45 e o instituto da repercussão geral. Reforma do Judiciário (obra coletiva). São Paulo: RT, 2005, p. 64 apud CRUZ E TUCCI, José Rogério. Anotações sobre a repercussão geral como pressuposto de admissibilidade do recurso extraordinário (Lei 11.418/2006), cit., p. 157.

${ }^{365}$ SARTORIO, Élvio Ferreira e JORGE, Flávio Cheim. O recurso extraordinário e a demonstração da repercussão geral. In: Reforma do Judiciário (obra coletiva). São Paulo: RT. 2005, p. 186 apud CRUZ E TUCCI, José Rogério. Anotações sobre a repercussão geral como pressuposto de admissibilidade do recurso extraordinário (Lei 11.418/2006), cit., p. 157-158.
} 
Este entendimento, agora pacificamente aceito (em nome do princípio da utilidade/necessidade), não pôde ser extraído dos termos como veio posta a MP 2226/01, pois a regulamentação total da transcendência foi atribuída ao Tribunal Superior do Trabalho, o que contribuiu para a sua não-implantação, mormente pelas incertezas deixadas e pelos desafios abertos. ${ }^{366}$

Outra grande novidade que merece destaque é a possibilidade contida no art. 543-B do CPC, que permite ao juízo de origem pinçar um ou mais recursos, no caso de haver vários sobre causas idênticas, para que apenas sobre aqueles o STF venha a pronunciar-se, com referência à repercussão geral das matérias que trazem no seu bojo.

O intuito do legislador foi minimizar o impacto da multiplicidade de recursos extraordinários lastreados em uma idêntica questão constitucional controvertida.

Noutros termos, existindo repetição de recursos sobre o mesmo tema, atribui-se aos tribunais de origem a função de selecionar um ou mais desses apelos que tratem a matéria para, então, enviá-los ao STF; sobresta-se o processamento dos demais, até o pronunciamento definitivo da Corte (art. 543-B, $\S 1^{\text {o }}$ do CPC). ${ }^{367}$

Caso não haja repercussão geral, os recursos extraordinários serão automaticamente inadmitidos (art. 543-B, $\S 2^{\circ}$ do CPC); em sentido oposto, reconhecida a repercussão e julgado o mérito, os que foram sobrestados deverão ser decididos em obediência à orientação firmada pelo Supremo, vale dizer, com efeito vinculante. ${ }^{368}$

O $\S 3^{\circ}$ do art. 543-B do CPC prevê que, na primeira hipótese, os tribunais de origem poderão declarar os recursos prejudicados ou, na segunda situação, o que é uma novidade, poderão as Cortes exercitar juízo de retratação, situação esta, anteriormente, só encontrável nos agravos. Não ocorrendo qualquer uma das hipóteses, admitido o recurso extraordinário, o STF poderá “cassar ou reformar, liminarmente, o acórdão contrário à orientação firmada" (art. 543-B, $\S 4^{\circ}$ do CPC).

\footnotetext{
${ }^{366}$ Wagner D. Giglio (O requisito prévio da transcendência, cit., p. 17) viu dificuldade insuperável de acesso ao Supremo Tribunal Federal caso o prévio exame da transcendência fosse feito antes dos requisitos específicos, como, por exemplo, uma grave violação constitucional ou legal poderia acontecer e, no entanto, não teria sido analisada pelo TST, que, antes, limitou-se a analisar a transcendência, sequer prequestionando a matéria de fundo.

${ }^{367}$ CRUZ E TUCCI, José Rogério. Anotações sobre a repercussão geral como pressuposto de admissibilidade do recurso extraordinário (Lei 11.418/2006), cit., p. 159.

${ }^{368}$ THEODORO JUNIOR, Humberto; NUNES, Dierle; BAHIA, Alexandre. op. cit., p. 30.
} 
Esse tratamento dos casos como standarts é defendido pelo Ministro Gilmar Mendes, que vê resistência a esse tipo de procedimento por causa da tendência de se tratarem as relações jurídicas quase sempre pelo viés individual e, não, o coletivo ou de massa, aliás, próprio do século passado e deste.

Os norte-americanos, idealizadores do controle incidental de inconstitucionalidade, por outro lado, "há muito se libertaram desse paradigma subjetivo. Creio que desde 1925, pelo menos, eles descobriram que este processo era, somente na aparência, um processo de partes. (...) E isso porque sabiam os americanos que aquele caso (...) era um caso pretexto. A rigor, era sabido que, quando se discutia um caso, o importante não era o caso em si, mas o seu tema., 369

Humberto Theodoro Júnior, Dierle Nunes e Alexandre Bahia apontam, no entanto, os riscos desse procedimento:

O mecanismo de pinçamento é uma clara técnica de varejo para solucionar um problema do atacado, que somente poderia ser abordado adequadamente tematizando-se a utilização de procedimentos coletivos representativos, devidamente compreendidos e estruturados, e mediante técnicas de processo-modelo, que se afastam do julgamento dos processos-teste. Ademais, as demandas do sistema jurídico devem ser soluciondas de modo constitucionalmente adequado e não exterminadas como uma chaga. Nossa proposta, dessa forma, no que tange à repercussão geral, caso prevaleça a irreversibilidade do instituto, é no sentido de que o tribunal de origem deveria tomar as principais razões expostas pela partes (por exemplo dando prazo para estas fazerem um briefing de suas razões principais) para então enviá-las ao STF. Depois, quando da decisão do STF, esta não deveria ser aplicada cegamente, fazendo "tabula rasa" do conteúdo dos processos; ao contrário, o tribunal de origem deveria aplicá-la de acordo com cada caso concreto. ${ }^{370}$

Finalmente, há de ser feita breve alusão ao art. 543-C do CPC, que disciplina o processamento dos recursos dirigidos ao Superior Tribunal de Justiça, que estejam fundamentados em idênticas questões de direito, os chamados recursos repetitivos.

Não se trata, como nos casos da relevância, da transcendência e da repercussão geral, de um pressuposto recursal específico, mas de mera técnica procedimental de

\footnotetext{
${ }^{369}$ MENDES, Gilmar Ferreira. A eficácia das decisões de inconstitucionalidade: 15 anos de experiência. In: SAMPAIO, José Adércio Leite (coord.). Quinze anos de constituição. Belo Horizonte: Del Rey, 2004, p. 203-208 apud THEODORO JUNIOR, Humberto; NUNES, Dierle; BAHIA, Alexandre. op. cit., p. 36-37.

${ }^{370}$ THEODORO JUNIOR, Humberto; NUNES, Dierle; BAHIA, Alexandre. op. cit., p. 38-39.
} 
julgamento, buscando simplificação e agilidade, o que evidencia grande compatibilidade com o processo do trabalho e vem sugerida no anteprojeto de lei minutado pela última Comissão da Transcendência. ${ }^{371}$

Se houver múltiplos recursos a respeito da mesma matéria, cabe ao Presidente do Tribunal local admitir um ou mais dos que sejam representativos da controvérsia, os quais, então, serão encaminhados à análise do STJ; os outros ficam suspensos até que haja pronunciamento definitivo acerca daqueles encaminhados como representativos (art. 543C, $\S 1^{\circ}$ do CPC).

A propósito, faça-se um pequeno parêntese para se dar notícia a respeito de prática usada com sucesso: a adoção na Corte a quo dessa sistemática de seleção, agrupamento, contenção, balizamento e espera de uma solução uniforme por parte da Corte ad quem vem sendo feita pela Vice-Presidência do Tribunal Superior do Trabalho na análise dos recursos extraordinários que lhe são apresentados, como, é o exemplo do Processo RE-ED-AIRR 31540-88.2006.5.02.0062 no qual se discute a responsabilidade subsidiária da pessoa de direito público nas terceirizações, pela aplicação do item IV do Súmula 331/TST. ${ }^{372}$

Nos termos do $\S 2^{\circ}$ do art. 543-C do CPC, caso o Presidente do Tribunal de origem deixe de cumprir o quanto previsto pelo $\S 1^{\circ}$ do mesmo dispositivo legal, cabe ao relator identificar que sobre a controvérsia já existe jurisprudência dominante ou que já há, na Seção ou na Corte Especial, recurso especial selecionado para julgamento. Pode, assim, determinar a suspensão, nos tribunais de segundo grau de jurisdição, daqueles recursos nos quais a controvérsia esteja delimitada.

Julgado o recurso escolhido, são duas as hipóteses para aqueles cujo trâmite ficou suspenso: nega-se seguimento, caso o acórdão recorrido coincida com a decisão do STJ ou, se houver divergência com esta última, há novo exame, pelo Tribunal de origem (art. 543C, $\S 7^{\circ}$ do CPC).

\footnotetext{
${ }^{371}$ Vide, mais abaixo, o inteiro teor do anteprojeto de lei oferecido pela Comissão da Transcendência, precisamente no "art. 896-C".

${ }^{372}$ Acompanhamento e despachos da Vice-Presidência do TST podem ser obtidos no sítio TRIBUNAL SUPERIOR DO TRABALHO. $<$ http://ext02.tst.jus.br/pls/ap01/ap_red100.resumo?num_int=452928\&ano_int=2008\&qtd_acesso=5451125 >. Acesso em: 23 out. 2010 .
} 
Nessa segunda situação, se o acórdão divergente for mantido pelo Tribunal local, far-se-á o exame de admissibilidade do recurso especial e, se positivo, será encaminhado será para a Corte Superior (art. 543-C, $\S 8^{\circ}$ do CPC). ${ }^{373}$

Conforme ponderam Luiz Rodrigues Wambier e Rita de Cássia Corrêa de Vasconcelos, o grande problema que se apresenta ao intérprete diz respeito à identificação do que vem a ser questões substancialmente idênticas:

Pode ocorrer que se dê a suspensão indevida de recurso que não trata exatamente da mesma questão de direito. Em que pese essa possibilidade concreta, e de sua potencialidade para causar dano à parte, não prevê a lei qualquer mecanismo processual de impugnação às decisões dos presidentes dos tribunais de origem. Do mesmo modo, há omissão na Res. STJ 8, de 07.08.2008, que trata dos procedimentos relativos ao processamento e julgamento de recursos especiais repetitivos. ${ }^{374}$

A Resolução STJ 8/2008 prevê que "serão selecionados pelo menos um processo de cada Relator e, dentre esses, os que contiveram maior diversidade de fundamentos no acórdão e de argumentos no recurso especial", levando-se em consideração "a questão central discutida”. Esses últimos Autores citados, no entanto, afirmam que é possível, sem risco de erro, que a aplicação da nova disciplina legal deve ocorrer somente quando não houver dúvida de que se está tratando de questões de direito verdadeiramente idênticas, sob pena de desvirtuar o sentido da lei e de incorrer em inconstitucionalidade por violação ao princípio do acesso à justiça. ${ }^{375}$

Vê-se, portanto, que a sucinta análise aqui feita da antiga arguição de relevância, confrontada com a repercussão geral e com o sistema dos processos repetitivos, está a evidenciar a enorme gama de detalhes que faltou ser abordada na criação e implementação da transcendência do recurso de revista, cujo "processamento" (assim o diz o art. $2^{\circ}$ da MP 2226/01) não poderia ter ficado ao exclusivo descortino Tribunal Superior do Trabalho, sendo imprescindível o concurso dos representantes do povo.

\footnotetext{
${ }^{373}$ WAMBIER, Luiz Rodrigues; VASCONCELOS, Rita de Cássia Corrêa de. Sobre a repercussão geral e os recursos especiais repetitivos, e seus reflexos nos processos coletivos. Revista dos Tribunais, São Paulo, ano 98 , v. 882, p. 35, abr. 2009.

${ }^{374}$ Id. Ibid., p. 33-34.

${ }^{375}$ Id. Ibid., p. 43-44.
} 


\subsection{O Devido Processo Legal e Processo do Trabalho}

Neste momento, sempre com o propósito de analisar a transcendência do recurso de revista, cabe relembrar alguns traços essenciais do devido processo legal, cuja matriz constitucional irradia-se pelo processo em geral e, sobre o do trabalho, em particular, pois este visa a concretização dos direitos sociais, dentre outros, tratados no art. $7^{\circ}$ da Carta Política, cujo caput, ao enunciar o viés da melhoria da condição social do trabalhador, confirma, também, o caráter tuitivo do próprio Direito do Trabalho.

O processo do trabalho, portanto, há de ser visto como um instrumento peculiar destinado à concretização dos direitos e garantias fundamentais dos trabalhadores em geral, assim definidos no Título II da Constituição Federal.

Com efeito, é de todos consabido que o chamado direito ao processo ou direito à tutela jurisdicional do Estado não se restringe à mera possibilidade de o membro da sociedade (nacional ou estrangeiro) ter acesso aos órgãos do Poder Judiciário, mas pressupõe, necessariamente, que o aparelho estatal incumbido desse mister se paute dentro de prévias e determinadas regras, que assegurem igualdade de tratamento frente a parte contra quem se contende, que o julgamento seja justo e público, realizado por Tribunal independente e imparcial e dentro de prazo razoável de duração.

Estas características, em linhas gerais, foram afirmadas no Século XX e restaram consagradas, por exemplo, no art. 10 da Declaração Universal dos Direitos do Homem, no art. $6^{\circ}$ da Convenção Européia para a Salvaguarda dos Direitos do Homem e das Liberdades Fundamentais, no art. 14 do Pacto Internacional de Direitos Civis e Políticos e no art. $8^{\circ}$ da Convenção Americana Sobre Direitos Humanos (São José da Costa Rica), esta última, aliás, que alude, de forma explícita, à busca de direitos trabalhistas por parte da pessoa humana, escapando, um pouco, da tônica antes prevalente, que se preocupava mais com a questão criminal, tal como nos mostraram Rogério Lauria Tucci e José Rogério Cruz e Tucci. ${ }^{376}$

Na mesma linha de idéias é o que prelecionam Gilmar Ferreira Mendes, Inocêncio Mártires Coelho e Paulo Gustavo Gonet Branco, ao tratar dos direitos fundamentais de

${ }^{376}$ TUCCI, Rogério Lauria; CRUZ E TUCCI, José Rogério. op. cit., p. 11-12. 
caráter judicial e das garantias constitucionais do processo, dando relevo especial à Convenção Européia de Direitos Humanos, cujo art. $6^{\circ}$, I, consagra sete direitos de caráter judicial. $^{377}$

O exercício, portanto, da garantia constitucional prevista no inciso XXXV do art. $5^{\circ}$ da Carta Política Brasileira de 1988 há de se desenvolver no ambiente do também consagrado devido processo legal, reiterado no inciso LIV do mesmo preceito constitucional, de tal modo que, no Estado Democrático de Direito, segundo Rogério Lauria Tucci e José Rogério Cruz e Tucci, de forma imperiosa, o devido processo legal exige:

a) elaboração regular e correta da lei, bem como de sua razoabilidade, senso de justiça e enquadramento nas preceituações constitucionais (substantive due process of law, segundo o desdobramento da concepção americana) ;

b) aplicação judicial da lei através de instrumento hábil à sua interpretação e realização, que é o processo (judicial process); e

c) assecuração, neste, da paridade de armas entre as partes, visando à igualdade substancial. ${ }^{378}$

A expressão devido processo legal corresponde à tradução, para o português, da locução inglesa due process of law. Os portugueses optaram por denominá-la processo equitativo, os italianos, processo giusto. Aliás, na Europa, é comum o uso do termo fair trial. 379

A doutrina majoritária considera que o primeiro ordenamento que teria feito menção ao princípio do devido processo legal seria a Magna Carta, de João Sem-Terra, em 1215, ao referir-se à law of land. De forma expressa, no entanto, o termo due process of law foi utilizado somente no Statute of Westminster of the Liberties of London, lei inglesa de $1354^{380}$.

\footnotetext{
${ }^{377}$ MENDES, Gilmar Ferreira; COELHO, Inocêncio Mártires; BRANCO, Paulo Gustavo Gonet. op. cit., p. 491.

${ }^{378}$ TUCCI, Rogério Lauria; CRUZ E TUCCI, José Rogério. op. cit., p. 15-16.

${ }^{379}$ DIDIER JR., Fredie. Curso de direito processual civil. 12. ed. Salvador: Jus Podium, 2010. v. 1, p. 41.

${ }^{380}$ NERY JUNIOR, Nelson. Princípios do processo na Constituição Federal. 9. ed. São Paulo: Ed. Revista dos Tribunais, 2009. p. 78.
} 
Tenha-se presente, todavia, o alerta feito por José Manoel de Arruda Alvim Neto, segundo o qual "nos Estados Unidos, até hoje, não se definiu, exaurientemente, o que seja, e, muito menos, qual o efetivo alcance que tenha a expressão due process of law, conforme informa a literatura." 381

O conceito de devido processo, portanto, não é estático e sujeita-se aos influxos da sociedade e de seu tempo. Trata-se de cláusula geral, ou seja, de termo em relação ao qual há indeterminação legislativa e cuja concretude depende da atividade jurisdicional. Justamente por isso, o conteúdo da cláusula geral do devido processo legal modificou-se, ao longo da história.

Tercio Sampaio Ferraz Jr. assim esclarece, acerca da historicidade do direito:

Destarte, assim como o homem $f a z$ a história, cujo processo deve ser captado pelo cientista de modo objetivo, ao perceber-lhe as leis de formação, do mesmo modo o homem $f a z$ o direito historicamente. Entretanto, como esse processo é análogo ao de qualquer fabricação (a história como um fazer e não como um agir), ele também tem um começo, um meio e um fim. Ora, o direito feito, ao cabo do processo, é o direito vigente. ${ }^{382}$

Fredie Didier Jr., citando Vicenzo Vigoriti, destaca, especificamente, a historicidade do conceito de devido processo legal, salientando a impossibilidade de o instituto ser compreendido da mesma forma, seja à época do absolutismo monárquico (século XIV), seja à época da consolidação da igualdade formal e da separação entre Igreja e Estado (século XX) e, enfim, hodiernamente, quando do advento da globalização e da sociedade de massas. Veja-se o seguinte trecho:

Um bom exemplo para demonstrar essa historicidade é o direito ao juiz natural, atualmente conteúdo do devido processo legal. Trata-se de uma conquista moderna. Resultou de fato infrutífera a tentativa de remeter suas origens à Magna Carta, pois esta, em seus arts. 20, 21, 39, 52 e 56, limita-se a estabelecer que para a condenação de qualquer cidadão é necessário um 'legale iudicium parium suorum', em que a condição de que os jurados sejam pares, ou 'homens probos da vizinhança', indica apenas uma qualidade dos juízes, e, no máximo, um critério de competência territorial, mas não tem nada que ver com a proibição da

\footnotetext{
${ }^{381}$ ALVIM NETO, José Manoel Arruda. op. cit., p. 77, de onde também se extrai a conclusão segundo a qual as circunstâncias do caso concreto apresentado possibilitarão que a Corte Suprema Americana diga se foi ou, não, observada a cláusula do devido processo, cuja essência residiria "na oportunidade plena e justa" para audiência da parte.

${ }^{382}$ FERRAZ JR., Tercio Sampaio. Introdução ao estudo do direito. 3. ed. São Paulo: Atlas, 2001. p. 78.
} 
instituição do juiz post factum. Essa proibição se afirma só no sec. XVII, contemporaneamente às primeiras manifestações de independência e aos conflitos já mencionados entre juízes e soberanos. ${ }^{383}$

O devido processo legal pode ser compreendido sob duas dimensões, a formal (ou procedimental) e a substancial (ou material).

Sob a primeira perspectiva, no direito brasileiro, o instituto está previsto no inciso LIV do art. $5^{\circ}$ da Constituição Federal, segundo o qual "ninguém será privado da liberdade ou de seus bens sem o devido processo legal".

No ordenamento jurídico geral estão consignados os desdobramentos desse princípio capazes de compor seu conteúdo mínimo e concretizá-lo, sob o aspecto formal, como direito fundamental que é. Assim, é preciso observar o contraditório e a ampla defesa (art. $5^{\circ}, \mathrm{LV}$ da CFRB/88), dar tratamento paritário às partes do processo (art. $5^{\circ}, \mathrm{I}$ do $\mathrm{CPC}$ ); proíbem-se as provas ilícitas (art. 5, LVI da CFRB/88); garante-se a publicidade do processo (art. 93, IX da CFRB/88); as decisões hão de ser motivadas (art. 93, IX da CFRB/88); o processo deve ter duração razoável (art. 5, LXXVIII da CFRB/88).

Não se pode olvidar, ainda, dos chamados princípios implícitos, tais como a boa-fé processual, a efetividade, a adequação, a lealdade e a cooperação (art. 14, II e seu parágrafo único, e art. 339, ambos do CPC).

Nos EUA, desenvolveu-se, também, a concepção do aspecto substancial desse princípio, de modo que devido processo legal é aquele que, para além da observância de garantias formais, é capaz de gerar decisões jurídicas substancialmente justas e devidas. ${ }^{384}$

Nelson Nery Júnior fornece-nos exemplos da manifestação do devido processo legal, no sentido material:

O devido processo legal se manifesta em todos os campos do direito, em seu aspecto substancial. No direito administrativo, por exemplo, o princípio da legalidade nada mais é do que manifestação da cláusula substantive due process. Os administrativistas identificam o fenômeno do due process, muito embora sob outra roupagem, ora denominando-o de garantia da legalidade e dos administrados, ora vendo nele o postulado da

\footnotetext{
${ }^{383}$ VIGORITI, Vicenzo. Garanzie costituzionali del processo civile. Milão: Giuffrè, 1973, p. 35 e 38-39 apud DIDIER JR., Fredie. op. cit., v. 1, p. 43.

${ }^{384}$ DIDIER JR., Fredie. op. cit., v. 1, p. 43-82.
} 
legalidade. Já se identificou a garantia dos cidadãos contra os abusos do poder governamental, notadamente pelo exercício do poder de polícia, como sendo manifestação do devido processo legal.

\section{(...)}

Vamos encontrar outros exemplos de incidência do substantive due process no direito americano, o que nos dá a dimensão do alcance do preceito: a) a liberdade de contratar, consubstanciada na "cláusula de contrato", afirmada no caso Fletcher v. Peck (1810) em voto de Marshal; b) a garantia do direito adquirido (vested rights doctrine); c) a proibição da retroatividade da lei penal; d) a garantia do comércio exterior e interestadual (commerce clause), fiscalizados e regrados exclusivamente pela União (CF 22 VIII; art. $1^{\circ}$, Secção $8^{\mathrm{a}}$, n. III, da Constituição norteamericana); e) os princípios tributários da anualidade, da legalidade, da incidência única (non bis in idem) etc.; f) a proibição de preconceito racial; g) a garantia dos direitos fundamentais do cidadão. ${ }^{385}$

Ainda no sentido material, a jurisprudência do Supremo Tribunal Federal extrai da cláusula geral do devido processo legal os deveres de proporcionalidade ou razoabilidade. Há decisão paradigmática, proferida pelo Ministro Celso de Mello, nos autos do RE 374.981, que trata dessa temática:

Não se pode perder de perspectiva, neste ponto, em face do conteúdo evidentemente arbitrário da exigência estatal ora questionada na presente sede recursal, o fato de que, especialmente quando se tratar de matéria tributária, impõe-se, ao Estado, no processo de elaboração das leis, a observância do necessário coeficiente de razoabilidade, pois, como se sabe, todas as normas emanadas do Poder Público devem ajustar-se à cláusula que consagra, em sua dimensão material, o princípio do "substantive due process of law" (CF, art. $\left.5^{\circ}, \mathrm{LIV}\right)$, eis que, no tema em questão, o postulado da proporcionalidade qualifica-se como parâmetro de aferição da própria constitucionalidade material dos atos estatais, consoante tem proclamado a jurisprudência do Supremo Tribunal Federal (RTJ 160/140-141 - RTJ 178/22-24, v.g.):

"O Estado não pode legislar abusivamente. A atividade legislativa está necessariamente sujeita à rígida observância de diretriz fundamental, que, encontrando suporte teórico no princípio da proporcionalidade, veda os excessos normativos e as prescrições irrazoáveis do Poder Público. O princípio da proporcionalidade - que extrai a sua justificação dogmática de diversas cláusulas constitucionais, notadamente daquela que veicula a garantia do substantive due process of law - acha-se vocacionado a inibir e a neutralizar os abusos do Poder Público no exercício de suas funções, qualificando-se como parâmetro de aferição da própria constitucionalidade material dos atos estatais. A norma estatal, que não veicula qualquer conteúdo de irrazoabilidade, presta obséquio ao postulado da proporcionalidade, ajustando-se à cláusula que consagra, em

\footnotetext{
${ }^{385}$ NERY JUNIOR, Nelson. op. cit., p. 82-83.
} 
sua dimensão material, o princípio do substantive due process of law (CF, art. $5^{\circ}$, LIV).

Essa cláusula tutelar, ao inibir os efeitos prejudiciais decorrentes do abuso de poder legislativo, enfatiza a noção de que a prerrogativa de legislar outorgada ao Estado constitui atribuição jurídica essencialmente limitada, ainda que o momento de abstrata instauração normativa possa repousar em juízo meramente político ou discricionário do legislador."

(RTJ 176/578-580, Rel. Min. CELSO DE MELLO, Pleno)

Em suma: a prerrogativa institucional de tributar, que o ordenamento positivo reconhece ao Estado, não lhe outorga o poder de suprimir (ou de inviabilizar) direitos de caráter fundamental, constitucionalmente assegurados ao contribuinte, pois este dispõe, nos termos da própria Carta Política, de um sistema de proteção destinado a ampará-lo contra eventuais excessos cometidos pelo poder tributante ou, ainda, contra exigências irrazoáveis veiculadas em diplomas normativos por este editados. ${ }^{386}$

Conclui-se assim que, no Brasil, o devido processo legal existirá se for célere, adequado, isonômico, proporcional, leal, justo etc.

No âmbito do Processo do Trabalho, todavia, para além dos princípios genéricos que concretizam a noção de devido processo legal, há peculiaridades naturais e lógicas porque, nem lá nem aqui, o processo é um fim em si mesmo, servindo, em verdade, como instrumento para a realização do direito material que lhe é correlato, no caso, o Direito do Trabalho.

É nessa linha, a síntese que faz Manoel Carlos Toledo Filho, ao invocar farta doutrina nacional e estrangeira a propósito dos princípios que singularizam o direito processual do trabalho, em comparação com o processo civil, destacando o que denomina o ideário instrumental, o intercâmbio e assimilação recíproca, que ocorre entre esses dois ramos do processo (v.g. na busca da rapidez, simplicidade, gratuidade, impulso oficial, conciliação e no trato de direitos indisponíveis) e, ainda, a jurisdição especializada na coadjuvação para o consecução desse mister, com juízes mais céleres, mais acessíveis e

\footnotetext{
${ }^{386}$ SUPREMO TRIBUNAL FEDERAL. Disponível em: <http://www.stf.jus.br/portal/diarioJustica/verDiarioProcesso.asp?numDj=67\&dataPublicacaoDj=08/04/20

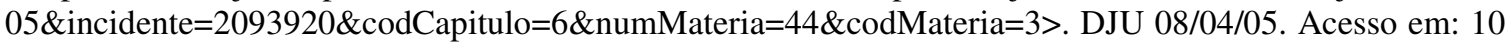
out. 2010. DJU 08/04/05.
} 
menos formalistas, como preconizava Juan Eduardo Couture, citado por esse Autor, o que há de valer para todos os graus da jurisdição trabalhista. ${ }^{387}$

Em apertada síntese, o processo do trabalho há de ser instrumento de realização dos direitos sociais porque eles estão jungidos e são indissociáveis da pessoa do trabalhador, constitucionalmente protegido sob todos os aspectos de sua condição humana e respectiva dignidade, vale dizer, credor da efetivação dos direitos e garantias fundamentais a ele inerentes.

Para Humberto Theodoro Júnior, citado por Carlos Henrique Bezerra Leite,

o primeiro e mais importante princípio que informa o processo trabalhista, distinguindo-o do processo civil comum, é o da finalidade social, de cuja observância decorre uma quebra do princípio da isonomia entre as partes, pelo menos em relação à sistemática tradicional do direito formal. $^{388}$

Ao lado da finalidade social do processo do trabalho, alinha-se o princípio da proteção, sendo que ambos se diferenciariam pelo fato de, em relação a este último, será a própria lei que ira conferir a desigualdade no plano processual, enquanto que o princípio da finalidade social permite uma atuação mais ativa por parte do juiz, no que tange à busca de uma solução justa , ${ }^{389}$ daí a importância da parte final do art. $8^{\circ}$ da CLT ("mas sempre de maneira que nenhum interesse de classe ou particular prevaleça sobre interesse público").

Além desses, tem especial relevo o princípio da busca da verdade real, extraído do princípio da primazia da realidade, explicitamente posto no art. 765 da CLT, concitando os Juízes a buscá-la, por isso que autorizados a determinar quaisquer diligências que sejam necessárias para a solução rápida, verdadeira e justa das causas.

\footnotetext{
${ }^{387}$ TOLEDO FILHO, Manoel Carlos, op. cit. p. 43-52. Este Autor alude à tendência contemporânea de unificação do processo civil e do trabalho: "De sorte que a separação entre o Direito Processual do Trabalho e o Direito Processual comum deve ser modernamente apreendida como de cunho exclusivamente procedimental; por conseguinte, admitida que seja a existência de uma autonomia entre eles, tal autonomia a esta dimensão deverá subsumir-se, a tal limite deverá restringir-se" (p.50), para, em seguida, concluir que "se é certo que o Processo trabalhista representou o "germe da renovação do Processo Civil comum" este, agora, é quem está contribuindo para a renovação do Processo obreiro..." (p.51)

${ }^{388}$ LEITE, Carlos Henrique Bezerra. op. cit., p. 87-88.

${ }^{389}$ Id. Ibid., p. 85-89.
} 
Cabem ser mencionados, por fim, os princípios da conciliação a qualquer tempo ou fase do processo (art. 764 da CLT) e o da oralidade/imediação (arts. 840, 847, 850 e 852-F da CLT). ${ }^{390}$

Poder-se-ia discutir como seria possível conciliar aquelas características que enformam a noção do devido processo legal com as peculiares do processo do trabalho, afastando eventuais conflitos.

É importante notar, todavia, que, tratando-se de harmonização de princípios, há de se buscar a maior efetividade dentro das possibilidades reais e jurídicas existentes.

São mandamentos de otimização, portanto, caracterizados pelo fato de poderem ser cumpridos em diferentes graus ${ }^{391}$, a partir de mecanismos de ponderação e, não, pela clássica subsunção do fato à norma, tal como ocorre na generalidade de aplicação das regras jurídicas.

A exigência de sopesamento dos princípios como maneira possível de aplicá-los pressupõe, num primeiro momento, que nenhum deles seja sacrificado em prol de outro. Ao contrário, o que se busca, como afirmado, é que cada um seja aplicado na maior medida ou intensidade possível.

O devido processo legal, no âmbito do Processo do Trabalho, há de reunir então, simultaneamente as qualidades de célere, adequado, isonômico, proporcional, leal, cooperativo, simples, protetivo, ferramenta de busca da verdade real e da finalidade social, ou seja, instrumento de concretização dos direitos sociais do ser humano que trabalha.

Feitas estas considerações de cunho geral sobre o devido processo legal do trabalho, voltando-se, então, para o novel instituto da transcendência, pressuposto específico de admissibilidade do recurso de revista, impõe-se questionar se com a sua introdução não estaria sendo desconsiderado algum desses princípios ou estaria sendo privilegiado um em detrimento de outro ou de outros, pois, iniludivelmente, como se extrai da mensagem que acompanhou a Medida Provisória 2226/01, esse novo pressuposto visa

\footnotetext{
${ }^{390}$ TOLEDO FILHO, Manoel Carlos, op. cit. p. 70.

${ }^{391}$ NERY JUNIOR, Nelson. op. cit., p. 25.
} 
criar mecanismo de limitação dos recursos a serem apreciados pelo Tribunal Superior do Trabalho.

De fato, ao lado do instituto da repercussão geral, criado pela EC 45/04 para os recursos extraordinários do STF, e o do mecanismo de trato dos processos repetitivos, aplicável aos recursos especiais do STJ, a transcendência, primordialmente, constitui busca de solução legislativa para diminuir a quantidade de recurso de revista e, também, o respectivo tempo de tramitação, exatamente nesta notória quadra de conflitos e de litigiosidade em massa.

Este, aliás, foi um ponderável motivo de sedução da maioria dos Ministros do STF, quando do julgamento da medida cautelar da ADI 2557, tal como se pode constatar dos fundamentos apresentados pela Relatora, Min. Ellen Gracie, redatora para o caso, naquele momento. ${ }^{392}$

Evidenciada está, portanto, a preocupação com a celeridade processual, ainda mais depois do advento do inciso LXXVIII do art. $5^{\circ}$ da Constituição Federal ${ }^{393}$, acrescentado pela EC 45/04, conquanto aquele inciso tenha surgido mais de três anos depois da MP 2226/01, o que, no entanto, só faz reforçar essa preocupação com a demora na solução dos conflitos trabalhistas.

$\mathrm{E}$, de fato, se o direito de acesso à jurisdição pressupõe uma razoável duração do instrumento jurídico destinado a concretizá-lo, qual seja, o processo, deverão o Estado e, de modo especial, o Poder Judiciário implementar medidas para atingir esse objetivo. E, como dizem Gilmar Ferreira Mendes, Inocêncio Mártires Coelho e Paulo Gustavo Gonet Branco:

$\mathrm{O}$ assunto envolve temas complexos e pretensões variadas, como a modernização e simplificação do sistema processual, a criação de órgãos judiciais em número adequado e a própria modernização e controle da prestação jurisdicional e de questões relacionadas à efetividade do acesso à Justiça. ${ }^{394}$

\footnotetext{
${ }^{392}$ SUPREMO TRIBUNAL FEDERAL. Disponível em: $<$ http://redir.stf.jus.br/paginador/paginador.jsp?docTP=AC\&docID=495496>. Acesso em: 11 out. 2010.

${ }^{393}$ Art. $5^{\circ}$, LXXVIII - a todos, no âmbito judicial e administrativo, são assegurados a razoável duração do processo e os meios que garantam a celeridade de sua tramitação. BRASIL. Constituição da República Federativa do Brasil de $1988 . \quad$ Disponível em: <http://www.planalto.gov.br/ccivil_03/Constituicao/Constituiçao.htm>. Acesso em: 10 out. 2010.

${ }^{394}$ MENDES, Gilmar Ferreira; COELHO, Inocêncio Mártires; BRANCO, Paulo Gustavo Gonet. op. cit., p. 501.
} 
Nessa perspectiva, por tudo o que se expôs no capítulo II a respeito da gênese da transcendência no processo do trabalho, há de se convir que o Poder Executivo, em boa hora (que já tardava), tomou a iniciativa de buscar um meio para por cobro ao grande acúmulo de processos em curso no Tribunal Superior do Trabalho, situação, todavia, que já era conhecida há longos anos e que vem comprometendo diretamente a celeridade do processo, conflitando com os postulados do due process of law.

E, como observou Estêvão Mallet, esse deplorável quadro de expectativa por uma solução dos processos, em geral, e os trabalhistas, em especial, dentro de uma razoável duração, só não foi pior graças ao surgimento no processo civil das tutelas de urgência (com sua aplicação ao trabalhista), a partir da EC 45/04, as quais ficaram, por assim dizer, imantadas de um caráter constitucional fundamental, ligado ao devido processo legal. ${ }^{395}$

Ora, caso seja posta em prática a transcendência, acredita-se que bom número de processos deixará de ter o respectivo mérito julgado, o que favoreceria a celeridade da causa em si e de outras, na medida em que "diminuiria a fila", com a licença da metáfora.

No entanto, por exemplo, numa hipótese, até corriqueira, de reclamação trabalhista na qual se discutem direitos de determinado trabalhador, advindos de condição contratual peculiar a determinada empresa e comum a outros tantos empregados, na mesma localidade ou região, em idêntica situação, mas que não se traduz em montante econômico considerável, tudo indica que a transcendência, sob esse critério isolado, deixaria de existir e, talvez, o aspecto social, também.

Assim, mirar, apenas, no princípio da celeridade e negar-se seguimento a recurso de revista desse empregado, implicaria incorrer no risco de se solaparem os princípios da proteção, da finalidade social, ou mesmo, da isonomia, repita-se, diretrizes muito caras e peculiares do processo do trabalho.

Não se ignora que, para a criação de regras restritivas de acesso a recursos, particularmente nos Tribunais Superiores, o Legislador tem em suas mãos a possibilidade de eleição de um critério objetivo, legalmente definido, ou de um critério amplo e difuso, a ser complementado ou colmatado pelo juiz.

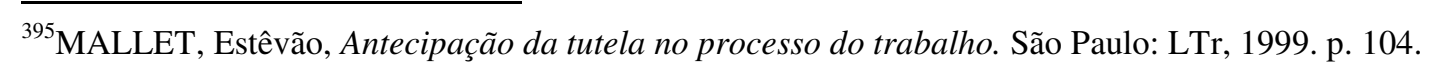


Ora, tanto um critério como o outro trazem riscos de se acobertarem grandes injustiças, como é o econômico ou o do valor da causa, já aplicáveis para obstar a revista nos processos de alçada (Lei 5584/70) ou naqueles submetidos ao rito sumaríssimo (art. $896, \S 6^{\circ}$ ), processos nos quais, todavia, pode estar em discussão matéria de alta relevância, por exemplo, ligada a dano moral, individual ou coletivo, ou, como antes analisado pelo Supremo Tribunal Federal, o detalhe de uma questão de legitimidade ativa, a substituição processual dos sindicatos, que até obrigou o TST a revogar sua Súmula 310.

Dificuldade semelhante se encontra, também, na restrição de acesso à revista nos processos de execução, quando se exige violação direta e literal de norma da Constituição Federal (art. 896, $\S 2^{\circ}$, da CLT), o que será difícil de ocorrer se levada à risca a jurisprudência do próprio Supremo Tribunal Federal sobre a contrariedade reflexa de preceito constitucional

A propósito, o Tribunal Superior do Trabalho, em várias situações em que se discutia pressuposto extrínseco recursal, à luz da lei vigente, (v. g. exigência de depósito), em nome do devido processo legal e do acesso à Justiça, formou jurisprudência abrandando o rigor da letra fria do $\S 2^{\circ}$ do art. 896 da CLT, como se vê na Súmula 128, II, o mesmo ocorrendo com o famoso código do DARF, preenchido errado pela parte, mas , por ter atingido sua finalidade fiscal, não poderia impedir o acesso ao julgamento, amparado em mero formalismo. ${ }^{396}$

\footnotetext{
${ }^{396}$ Nesse sentido, confira-se a seguinte e recente manifestação da SBDI-1 do TST: RECURSO ORDINÁRIO. DEPÓSITO RECURSAL. GUIA DE DEPÓSITO JUDICIAL. DESERÇÃO. NÃO OCORRÊNCIA. Afigura-se regular o depósito recursal para fins de recurso quando efetuado mediante guia de depósito judicial trabalhista, observados o prazo e valor legais e encontrando-se consignados na guia respectiva o nome do reclamante e do reclamado, a Vara do Trabalho em que tramitou o feito e o número do processo, além da autenticação do Banco recebedor da quantia. Não caracteriza a deserção do recurso o fato de o depósito ter sido efetuado em guia diversa da GFIP e fora da conta vinculada do FGTS. Recurso de embargos conhecido e provido. CUSTAS PROCESSUAIS. GUIA DARF. PREENCHIMENTO INCOMPLETO. AUSÊNCIA DO NOME DA PARTE RECORRIDA, DO NÚMERO DO PROCESSO A QUE SE REFERE E DA VARA DO TRABALHO EM QUE TRAMITOU O FEITO. Consoante a Instrução Normativa n. ${ }^{\circ}$ 20, com a redação dada pela Resolução Administrativa n. ${ }^{\circ}$ 902/2002 desta Corte superior, que dispõe sobre os procedimentos para o recolhimento de custas e emolumentos devidos à União no âmbito da Justiça do Trabalho (DJU de 13/11/2002), exige-se, tão somente, que o pagamento das custas seja efetuado no prazo recursal e no valor estipulado na sentença. Nas hipóteses em que incontroversamente verificado o efetivo recolhimento das custas em favor da União, não cabe perquirir a existência de irregularidades no preenchimento da guia DARF, sob pena de incorrer-se em ofensa ao disposto no artigo $5^{\circ}$, inciso LV, da Constituição da República. Recurso de embargos conhecido e provido. Processo: E-RR 119100-26.2005.5.07.0010 Data de Julgamento: 23/09/2010, Relator Ministro: Lelio Bentes Corrêa, Subseção I Especializada em Dissídios Individuais, Data de Publicação: DEJT 08/10/2010. Extraída do sítio do TRIBUNAL SUPERIOR DO TRABALHO. Disponível em: $<$ http://aplicacao2.tst.jus.br/consultaunificada2/>. Acesso em: 23 out. 2010.
} 
Como se vê, para que fosse possível a admissão do recurso de revista foi necessário analisar o que seria violação direta e literal da Constituição, fugindo-se da fria lei posta e partindo-se para os princípios constitucionais, mais abertos.

No caso da transcendência do recurso de revista, a passagem de critério legal estrito, definido no art. 896 da CLT, para a conjugação com um critério aberto, agora exposto no art. 896-A da CLT, a ser preenchido pelo Juiz, que não resultou de atuação do Congresso Nacional, mas de ato do Poder Executivo, quando editou a Medida Provisória 2226/01, tudo isso só realça a dificuldade de escolha de quais casos devem ser julgados.

A forte conotação política que impregna a edição dessa medida provisória, como vimos nos antecedentes históricos, assim como o critério de seleção engendrado, que não teve efeitos práticos, comprometem a eficácia e o desenvolvimento da criação.

Por isso, Ivo Dantas, valendo-se de Calmon de Passos, conquanto este abordasse o instituto da argüição de relevância, faz uma crítica incisiva à essa espécie de escolha política que ignora aqueles valores constitucionais acima indicados:

É, até certo ponto, a face sociológica do instituto, muito embora seja de enorme importância a lição que nos é dada por CALMON DE PASSOS: "na verdade, perquirir-se da relevância da questão para admitir-se o recurso é consequiência da irrelevância do indivíduo aos olhos do poder instituído. Considerar-se de pouca valia a lesão que se haja ilegitimamente infligido à honra, à vida, à liberdade ou o patrimônio de alguém, ou a outros bens que lhe sejam necessários ou essenciais é desqualificar-se a pessoa humana. Não há injustiça irrelevante! Salvo quando o sentimento de Justiça deixou de ser exigência fundamental na sociedade política. E quando isso ocorre, foi o Direito mesmo que deixou de ser importante para os homens. Ou quando nada para alguns homens os poderosos" - conclui o processualista.$^{397}$

É importante destacar que não se olvida a necessidade da criação de mecanismos capazes de amenizar o problema da multiplicação e da perpetuação dos conflitos, em confronto com a também crescente incapacidade do Poder Judiciário absorver e solucionar de forma justa e adequada (fair trail) as demandas que lhe são submetidas.

O que merece ser questionado é, afinal, se o instituto da transcendência seria a solução mais adequada e razoável para a superação desses óbices. Noutras palavras, se a

\footnotetext{
${ }^{397}$ DANTAS, Ivo. op. cit.
} 
sua adoção representa menor sacrifício às idéias motrizes do processo do trabalho e se outras iniciativas seriam mais adequadas e eficazes.

E, a propósito, vem novamente à baila o pensamento de Tercio Sampaio Ferraz Jr., segundo o qual, com a crescente complexidade das relações sociais, o Direito tornou-se uma técnica decisória. De fato, ao discorrer sobre a compreensão do fenômeno jurídico, observa que a dogmática, cuja evolução se deu desde o século XIX, acabou tornando-se não mais que um método de resolução de problemas. Confiram-se estas asserções:

O desenvolvimento da dogmática no século XIX, em termos de sua função social, passa a atribuir a seus conceitos um caráter abstrato que lhe permite uma emancipação das necessidades cotidianas dos interesses em jogo. Com isso tornou-se possível uma neutralização dos interesses concretos na formação do próprio direito, neutralização essa já exigida politicamente pela separação dos poderes e pela autonomia do poder judiciário. Além disso, no século XIX, a atividade dogmática não se vincula mais a nenhum direito sagrado, nem mesmo a um conteúdo ético teologicamente fundado, mas a formas abstratas, sobre as quais se dispõe com certa liberdade por meio de novas abstrações.

\section{(...)}

Nesse quadro, a ciência dogmática do direito, na tradição que nos vem do século XIX, prevalecentemente liberal, em sua ideologia, e encarando, por consequiência, o direito como regras dadas (pelo Estado, protetor e repressor), tende a assumir o papel de conservadora daquelas regras, que, então, são por ela sistematizadas e interpretadas. Essa postura teórica é denominada por Norberto Bobbio de teoria estrutural do direito. Nela prevalece um enfoque que tende a privilegiar as questões formais, como o problema mencionado da "natureza jurídica" dos institutos, da coerência do ordenamento jurídico, do estabelecimento de regras de interpretação, da conceituação analítica de noções básicas como obrigação, responsabilidade, relação jurídica, sanção como uma retribuição negativa (pena, castigo), sentido de ato lícito e ilícito, direito subjetivo etc. O enfoque estrutural, em suma, é um enfoque a posteriori, que toma o direito dado e procura as condições de sua aplicação.

Podemos dizer, nesse sentido, que a ciência dogmática do direito costuma encarar seu objeto, o direito posto e dado previamente, como um conjunto compacto de normas, instituições e decisões que lhe compete sistematizar, interpretar e direcionar, tendo em vista uma tarefa prática de solução de possíveis conflitos que ocorram socialmente. ${ }^{398}$

Nessa linha de considerações, portanto, a mera busca de redução ou eliminação dos conflitos trazidos a Juízo, se estiver desconectada dos princípios que compõem a noção do

\footnotetext{
${ }^{398}$ FERRAZ JR., Tercio Sampaio. Introdução ao estudo do direito. 3. ed., cit., p. 80-82.
} 
devido processo legal (formal e substancial), aplicáveis ao processo do trabalho, tudo isso pode comprometer e desvirtuar o sentido maior de Justiça e de Pacificação Social, inerentes ao Direito do Trabalho, ao Processo do Trabalho e à própria Justiça do Trabalho, singularmente concebida e estruturada com essa finalidade.

O recurso de revista, portanto, concebido e necessário para a busca da higidez da interpretação e da aplicação do direito federal do trabalho, não pode perder sua função instrumental de concretização de direitos humanos do trabalhador, daí não cabendo posição extremada no sentido de que ele não visa ou busca a realização de Justiça, o que, no âmbito do Direito Processual do Trabalho deve ser minorado e ponderado pelos motivos acima expostos (fair trail).

Afinal, insista-se, a própria existência do processo, em si, nada mais é do que o meio de concretizar o exercício do direito de ação, com vistas a obter do Estado uma prestação jurisdicional justa e pacificadora (e exemplar para os demais cidadãos e trabalhadores), atividade essencial no ambiente constitucional e democrático de direito, que em se prestigiam, protegem-se e se garantem os direitos fundamentais sociais.

Foi sob essa perspectiva de máxima proteção e garantia dos direitos fundamentais que José Guilherme Berman teceu crítica à fórmula adotada para a restrição ou contenção de processos no Supremo Tribunal Federal, através do mecanismo da repercussão geral. Partindo do fenômeno da constitucionalização do Direito e do chamado novo paradigma que vem tomando corpo com o neoconstitucionalismo, sustenta que

a proteção aos direitos fundamentais é trazida para o centro das preocupações do Direito Constitucional. Os Tribunais Constitucionais, como guardiões da Constituição, passam a ter, também, destacado papel de proteção aso direitos fundamentais consagrados naqueles textos. E, no exercício dessa relevante função, o modelo difuso-concreto de controle de constitucionalidade revela-se insubstituível. ${ }^{399}$

E arremata:

Em pouco tempo, o julgamento de recursos impetrados diretamente pelos cidadãos, justamente devido à amplitude de sua legitimidade ativa, tornou-se a principal atividade dos Tribunais Constitucionais, europeus. É o que acontece, por exemplo, na Alemanha, país no qual os recursos constitucionais (verfassungsberchwede) respondem por aproximadamente 97\% de todas as causas julgadas pela Corte. Como afirma uma expresidente do Tribunal Constitucional, "el recurso constitucional convierte a los ciudadanos y ciudadanas em guardianes de la Ley

${ }^{399}$ BERMAN, José Guilherme, op. cit., p. 127-128. 
Fundamental." No mesmo sentido, Peter Häberle considera que esta competência, que democratiza o acesso ao Tribunal Constitucional, o transforma em um "tribunal cidadão".

O exemplo espanhol é idêntico, com o recurso de amparo respondendo pela grande maioria das causas decididas pelo Tribunal Constitucional. No ano de 2003, por exemplo, de um total de 7.878 julgamentos, 7.721 referiam-se a tais recursos.

A trajetória do controle de constitucionalidade europeu, portanto, parece indicar que a presença de mecanismos que possibilitem o cidadão comum ter acesso ao Tribunal Constitucional é extremamente positiva no sentido de ampliar a proteção dos direitos fundamentais assegurados aos cidadãos pelo texto constitucional. ${ }^{400}$

Ora, mutatis mutandis, como sempre se invocam os exemplos estrangeiros e o que acontece com os Tribunais Constitucionais mundo afora, uma vez que o Tribunal Superior do Trabalho não está no vértice do Poder Judiciário, conquanto, na sua competência atual, como acontecia com o próprio Supremo Tribunal Federal, antes de 1988, acumule o controle de constitucionalidade e de legalidade, certo é que nesta precípua missão de resguardar a higidez de aplicação e de interpretação do direito federal trabalhista há de comportar-se como o Tribunal do Cidadão/Trabalhador, de sorte que as restrições de acesso devem ser muito bem sopesadas, para que não se sufoquem as mais legítimas aspirações de proteção e de garantia dos direitos fundamentais sociais.

Sob esse prisma é que se busca para o caso da transcendência uma compatibilização com o devido processo legal substancial.

Se, como diz José Guilherme Berman, o conceito de repercussão geral não se equipara ao de interesse público "porque não abrange, prima facie, a defesa dos direitos fundamentais dos cidadãos, como já salientava Evandro Lins e Silva na década de 70" 401 , na medida em que ignora "o papel do STF como protetor dos direitos fundamentais" ${ }^{402}$, invertidos os sinais, há de se repensar no efetivo papel constitucional do Tribunal Superior do Trabalho, cujo acesso, sem dúvida, não pode ser banalizado, mas merece reformulação mais abrangente do que aquela pensada quando da criação do pressuposto recursal da transcendência.

\footnotetext{
${ }^{400}$ BERMAN, José Guilherme, op. cit., p. 129.

${ }^{401}$ Id. p. 131

${ }^{402}$ Id. Ibid.
} 
E, aqui, para finalizar este capítulo, cabe ter presente o que Estêvão Mallet sintetizou a respeito da importância e da imprescindibilidade do recurso de revista, que não pode ser abolido

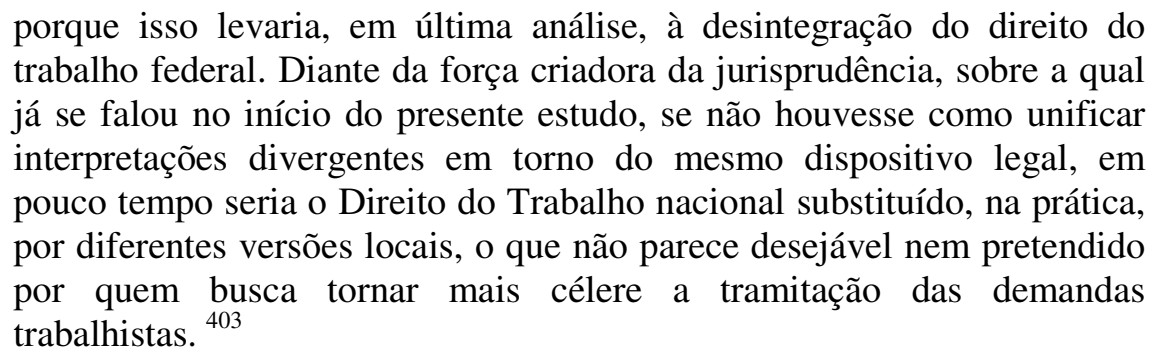

Esse mesmo Autor já alertava, porém, sobre a existência de alguns equívocos e desvios, ${ }^{404}$ alguns, por certo, já sanados com alteração da legislação e da jurisprudência, mas outros surgiram, como parece ter acontecido com o surgimento do pressuposto da transcendência através da Medida Provisória 2226/01, o que, ainda assim, não há de abalar a própria razão de existir do recurso de revista, por isso que se advogam soluções alternativas.

${ }^{403}$ MALLET, Estêvão, cit., p. 201.

${ }^{404}$ Id. Ibid., p. 203. 


\section{CAPÍTULO IV. A CRISE DA TRANSCENDÊNCIA}

\subsection{A constitucionalidade da Medida Provisória 2226/01}

Chegado é o momento de se tecerem mais comentários sobre a constitucionalidade da norma que criou a transcendência do recurso de revista, mas sob um prisma específico.

De fato, porque está em curso no Supremo Tribunal Federal, há mais de 9 anos, ação direta com essa finalidade, privilegia-se, agora, o exame desta ação, esquadrinhandose a respectiva inicial e a decisão da liminar proferida, confrontando-se esta última com a jurisprudência da própria Suprema Corte em torno da matéria discutida.

\section{Emprestar-se-á, portanto, à análise dessa constitucionalidade um enfoque} jurisprudencial praticamente exclusivo, invocada, também, a força vinculante dos motivos determinantes das decisões proferidas em ações diretas de inconstitucionalidade e ações declaratórias de constitucionalidade. ${ }^{405}$

De se relembrar, mais uma vez, que o pressuposto recursal específico da transcendência foi criado pela Medida Provisória $\mathrm{n}^{\mathrm{o}}$ 2.226, de 04 de setembro de 2001 (DOU 05.09.2001), cujos artigos $1^{\circ}$ e $2^{\circ}$ assim dispõem:

Art. $1^{\circ}$ A Consolidação das Leis do Trabalho, aprovada pelo Decreto-Lei $\mathrm{n}^{\circ}$ 5.452, de $1^{\circ}$ de maio de 1943 , passa a vigorar acrescida do seguinte dispositivo:

"Art. 896-A. O Tribunal Superior do Trabalho, no recurso de revista, examinará previamente se a causa oferece transcendência com relação aos reflexos gerais de natureza econômica, política, social ou jurídica." (NR)

Art. $2^{-} \mathrm{O}$ Tribunal Superior do Trabalho regulamentará, em seu regimento interno, o processamento da transcendência do recurso de

\footnotetext{
${ }^{405}$ No capítulo II (vide supra p. 84 ), ao ser apreciada a gênese da transcendência do recurso de revista por meio da MP 2226/01, já foram feitas algumas considerações doutrinárias a respeito das características fundamentais desse tipo normativo condicional, principalmente com a invocação dos ensinamento de José Afonso da Silva (Curso de direito constitucional positivo, cit., p. 532,) quando, para a legitimidade das medidas provisórias, alude à imprescindibilidade de serem atendidos os pressupostos formais (relevância e urgência), os de índole material (temas limitados pela própria estrutura constitucional) e, ainda, os de ordem procedimental (tramitação diferenciada), não havendo possibilidade de aprovação das medidas provisórias por decurso de prazo e sua convalidação pelo simples transcorrer do tempo, como, anteriormente, chegou a ocorrer com os decretos-leis.
} 
revista, assegurada a apreciação da transcendência em sessão pública, com direito a sustentação oral e fundamentação da decisão.

Em 14 de setembro de 2001, a Ordem dos Advogados do Brasil propôs a Ação Direta de Inconstitucionalidade $\mathrm{n}^{\mathrm{o}}$ 2.527, sustentando haver incompatibilidade constitucional daquela medida com os artigos $62,246,22,24, \S 3^{\circ}$ do art. 111 , arts. $1^{\circ}$ e $5^{\circ}$, II, XXXVI e LV e 37 da Carta Política.

Sobre a inexistência de relevância e urgência no que tange à questão da transcendência, sustentou a Ordem dos Advogados do Brasil, na petição inicial, o seguinte:

A Medida Provisória impugnada, todos os seus artigos, é inconstitucional por ofensa ao artigo 62 da Constituição. Medida Provisória só poder (sic) ser expedida em casos de relevância e urgência. Para haver relevância, necessário é que a matéria a ser objeto da deliberação governamental seja tal "que açambarque um interesse público fundamental, superior, inconfundível, inigualável, cuja regulação mereça prioridade." Já a urgência "é aquela que não pode esperar, que demanda solução imediata, sob pena de não acudir ou socorrer a situação de fato posta" (Da medida provisória, Livraria Del Rey Editora, 1994, pág. 142, Carlos Ramos).

A competência do Tribunal Superior do Trabalho resta prevista na legislação pátria há anos. Desnecessária era, pois, sua alteração pelo ato provisório. Não havia, evidentemente, urgência, situação que não pudesse esperar, até porque a matéria estava no Congresso Nacional, na sede legislativa própria, para apreciação (doc. 03). Por violência ao artigo 62, são inconstitucionais os artigos $1^{\circ}$ e $2^{\circ}$ da Medida Provisória 2226.

\section{(...)}

Por fim, quanto a esse ponto, assinala-se, as prescrições do ato provisório, todas elas (artigos 1], $2^{\circ}$ e $3^{\circ}$ ), tratam de matéria processual, tema que medidas provisórias não podem regrar, posto que a efemeridade de seus comandos é incompatível com a segurança que as ordens judiciais devem gozar, mormente quando revestidas da autoridade da coisa julgada ${ }^{406}$

Abordando a imprecisão normativa criada pela Medida Provisória e as consequiências do reconhecimento ou, não, da transcendência, a Ordem dos Advogados do

\footnotetext{
${ }^{406}$ SUPREMO TRIBUNAL FEDERAL. Disponível em: $<$ http://redir.stf.jus.br/estfvisualizadorpub/jsp/consultarprocessoeletronico/ConsultarProcessoEletronico.jsf? seqobjetoincidente=1970076> . Acesso em: 10 out. 2010 .
} 
Brasil fez específico destaque de fundamentação quanto à configuração de ofensa aos $\operatorname{artigos} 37,1^{\circ}, 5^{\circ}$, caput e inciso II, nos seguintes termos:

A esse propósito, atente-se para a lição de Gomes Canotilho, in Direito Constitucional e Teoria da Constituição $2^{\mathrm{a}}$ edição, Almedina, Coimbra, página 251, discorrendo acerca do princípio da seguranca jurídica como subprincípio concretizador do princípio do Estado de Direito, assevera:

"A segurança jurídica postula o princípio da precisão ou determinação dos actos normativos, ou seja, a conformação material e formal dos actos normativos em termos linguisticamente claros, compreensiveis e não contraditórios. Nesta perspectiva se fala de princípios jurídicos de normação jurídica concretizadores das exigências de determinabilidade, clareza e fiabilidade da ordem jurídica e, conseqüentemente, da segurança jurídica e do Estado de direito.

O princípio da determinabilidade das leis reconduz-se, sob o ponto de vista intrínseco, a duas idéias fundamentais. A primeira é a da exigência de clareza das normas legais, pois de uma lei obscura ou contraditória pode não ser possível, através da interpretação, obter um sentido inequívoco capaz de alicerçar uma solução jurídica para o problema concreto. A segunda aponta para a exigência de densidade suficiente na regulamentacão legal, pois um acto legislativo (ou um ato normativo em geral) que não contém uma disciplina suficientemente concreta (= densa, determinada) não oferece uma medida jurídica capaz de: (1) alicercar posições juridicamente protegidas dos cidadãos; (2) constituir uma norma de actuacãa para a administração; (3) possibilitar, como norma de controlo, a fiscalizacãa da legalidade e a defesa dos direitos $e$ interesses dos cidadãos.”

Exsurge, pois, pelos artigos $1^{\circ}$ e $2^{\circ}$ da Medida Provisória 2226, ofensa ao artigo $1^{\circ}$ (Princípio do Estado de Direito), ao artigo $5^{\circ}$, caput (Princípio da segurança, dentre ele a jurídica), com seu II e ao artigo 37 (Princípio da legalidade), todas da Constituição Federal, dos quais se extrai a necessidade de que as normas legais sejam suficientes para regrar a vida dos cidadãos e do Poder. ${ }^{407}$ (destaques do original)

Também foi alegado vício constitucional na delegação de competência para o C. TST regulamentar o processamento da transcendência em seu Regimento Interno, pois este não teria estatura de lei, tal como exigido pelo $\S 3^{\circ}$ do art. 111 da Constituição Federal (atual art. 113), o que conflitaria, ao mesmo tempo, com as regras dos artigos 22, I e 24, IX da Carta Política, quando alude à competência privativa da União para legislar sobre direito processual.

\footnotetext{
${ }^{407}$ SUPREMO TRIBUNAL FEDERAL. Disponível em: $<$ http://redir.stf.jus.br/estfvisualizadorpub/jsp/consultarprocessoeletronico/ConsultarProcessoEletronico.jsf? seqobjetoincidente=1970076>. Acesso em: 11 out. 2010 .
} 
Por fim, para justificar o requerimento da concessão de liminar suspensiva da eficácia da medida com força de lei, assim esclareceu a Ordem dos Advogados do Brasil:

Os artigos $1^{\circ}, 2^{\circ}$ e $3^{\circ}$ da Medida Provisória 2226 devem ter eficácia suspensa liminarmente, uma vez que presentes periculum in mora e conveniência da suspensão.

Os artigos $1^{\circ}$ e $2^{\circ}$ estão em vias de causar grandes prejuízos para o jurisdicionado.

A introdução da enigmática "transcendência" no processamento do recurso de revista, poderá acarretar o não conhecimento de recursos, conforme interpretar o TST essa lacônica norma, privando as partes do apelo a que têm direito. Até mesmo a jurisdição do Supremo Tribunal Federal poderá ser maculada, caso entenda a Suprema Corte Trabalhista que o obscuro e novel instituto permite-lhe deixar de apreciar recursos de revista. Isso porque, caso dela não conheça, o STF de recurso extraordinário que poderia ser deduzido na causa não poderá conhecer.

Mesmo que o Tribunal Superior do Trabalho, porém, não entenda que a "transcendência" é um requisito de admissibilidade, é certo que a sua inserção no processamento das revistas, seja para o fim que for,

ocasionará indevido e perigoso desvio do rumo próprio que os recursos de revista devem ter, podendo, por tais razões, mormente com a declaração de inconstitucionalidade ao final dos dispositivos que dela tratam na Medida Provisória (artigos $1^{\circ}$ e $2^{\circ}$ ), ensejar futuro questionamento da validade das causas que venham a ser julgadas, ou mesmo não julgadas, com apreciação da "transcendência". ${ }^{408}$

Só em 16 de agosto de 2007, vale dizer, quase completos seis anos após a edição da Medida Provisória, o Plenário do Supremo Tribunal Federal concluiu o julgamento da pretensão liminar de suspensão dos efeitos da medida com força de lei, deferindo-a, apenas em parte, exclusivamente com relação ao art. $3^{\circ}$, que trata de honorários advocatícios, os quais, pela proposta do Poder Executivo, haveriam de não ser devidos nas seguintes circunstâncias:

Art. $3^{\circ} \mathrm{O}$ art. $6^{\circ}$ da Lei $n^{\circ} 9.469$, de 10 de julho de 1997 , passa a vigorar acrescido do seguinte parágrafo, renumerando-se o atual parágrafo único para $\S 1^{\circ}$ :

"§ $2^{\circ} \mathrm{O}$ acordo ou a transação celebrada diretamente pela parte ou por intermédio de procurador para extinguir ou encerrar processo judicial, inclusive nos casos de extensão administrativa de pagamentos postulados

\footnotetext{
${ }^{408}$ SUPREMO TRIBUNAL FEDERAL. Disponível em: $<$ http://redir.stf.jus.br/estfvisualizadorpub/jsp/consultarprocessoeletronico/ConsultarProcessoEletronico.jsf? seqobjetoincidente=1970076>.Acesso em: 11 out. 2010 .
} 
em juízo, implicará sempre a responsabilidade de cada uma das partes pelo pagamento dos honorários de seus respectivos advogados, mesmo que tenham sido objeto de condenação transitada em julgado."

A maioria dos Membros da Suprema Corte, seguindo o voto da Ministra Ellen Gracie, optou pela manutenção dos dois primeiros artigos, exatamente os que tratam da transcendência, sendo conveniente, desde logo, apresentar a ementa do julgamento:

MEDIDA CAUTELAR EM AÇÃO DIRETA DE INCONSTITUCIONALIDADE. MEDIDA PROVISÓRIA 2.226, DE 04.09.2001. TRIBUNAL SUPERIOR DO TRABALHO. RECURSO DE REVISTA. REQUISITO DE ADMISSIBILIDADE. TRANSCENDÊNCIA. AUSÊNCIA DE PLAUSIBILIDADE JURÍDICA NA ALEGAÇÃO DE OFENSA AOS ARTIGOS $1^{\circ} ; 5^{\circ}$, CAPUT E II; 22, I; 24, XI; 37; 62, CAPUT E $\S 1^{\circ}$, I, B; 111, $\S 3^{\circ}$ E 246. LEI 9.469/97. ACORDO OU TRANSAÇÃO EM PROCESSOS JUDICIAIS EM QUE PRESENTE A FAZENDA PÚBLICA. PREVISÃO DE PAGAMENTO DE HONORÁRIOS, POR CADA UMA DAS PARTES, AOS SEUS RESPECTIVOS ADVOGADOS, AINDA QUE TENHAM SIDO OBJETO DE CONDENAÇÃO TRANSITADA EM JULGADO. RECONHECIMENTO, PELA MAIORIA DO PLENÁRIO, DA APARENTE VIOLAÇÃO AOS PRINCÍPIOS CONSTITUCIONAIS DA ISONOMIA E DA PROTEÇÃO À COISA JULGADA.

1. A medida provisória impugnada foi editada antes da publicação da Emenda Constitucional 32, de 11.09.2001, circunstância que afasta a vedação prevista no art. $62, \S 1^{\circ}$, I, b, da Constituição, conforme ressalva expressa contida no art. $2^{\circ}$ da própria EC 32/2001.

2. Esta Suprema Corte somente admite o exame jurisdicional do mérito dos requisitos de relevância e urgência na edição de medida provisória em casos excepcionalíssimos, em que a ausência desses pressupostos seja evidente. No presente caso, a sobrecarga causada pelos inúmeros recursos repetitivos em tramitação no TST e a imperiosa necessidade de uma célere e qualificada prestação jurisdicional aguardada por milhares de trabalhadores parecem afastar a plausibilidade da alegação de ofensa ao art. 62 da Constituição.

3. Diversamente do que sucede com outros Tribunais, o órgão de cúpula da Justiça do Trabalho não tem sua competência detalhadamente fixada pela norma constitucional. A definição dos respectivos contornos e dimensão é remetida à lei, na forma do art. $111, \S 3^{\circ}$, da Constituição Federal. As normas em questão, portanto, não alteram a competência constitucionalmente fixada para o Tribunal Superior do Trabalho.

4. Da mesma forma, parece não incidir, nesse exame inicial, a vedação imposta pelo art. 246 da Constituição, pois, as alterações introduzidas no art. 111 da Carta Magna pela EC 24/99 trataram, única e exclusivamente, sobre o tema da representação classista na Justiça do Trabalho. 
5. A introdução, no art. $6^{\circ}$ da Lei $n^{\circ} 9.469 / 97$, de dispositivo que afasta, no caso de transação ou acordo, a possibilidade do pagamento dos honorários devidos ao advogado da parte contrária, ainda que fruto de condenação transitada em julgado, choca-se, aparentemente, com a garantia insculpida no art. $5^{\circ}$, XXXVI, da Constituição, por desconsiderar a coisa julgada, além de afrontar a garantia de isonomia da parte obrigada a negociar despida de uma parcela significativa de seu poder de barganha, correspondente à verba honorária. 6. Pedido de medida liminar parcialmente deferido. ${ }^{409}$

Ao proferir seu voto, a Relatora, Min. Ellen Gracie, alegou não ter verificado "a presença de plausibilidade que enseje o deferimento da medida cautelar quanto aos artigos $1^{\circ}$ e $2^{\circ}$ da Medida Provisória n ${ }^{\circ} 2.226 / 01 " 410$.

Como se extrai da ementa acima transcrita, o primeiro e principal argumento de que se valeu a Ministra liga-se ao fato de a Medida Provisória em análise ser anterior à edição da Emenda Constitucional 32/01, de modo que ficaria afastada a vedação quanto à regulamentação de matérias relativas a direito penal, processual penal e processual civil. Além disso, enxergou a Ministra haver relevância e urgência na medida, particularmente em razão da sobrecarga de recursos repetitivos submetidos à análise do C. TST. Outro argumento utilizado residiria na inexistência de obstáculo constitucional para que o C. TST definisse o processamento do recurso de revista.

Nos longos debates que houve, em contraposição ao voto da Relatora, o Min. Nelson Jobim propugnou suspender o disposto nos artigos $1^{\circ}$ e $2^{\circ}$ da Medida Provisória 2226/01. Ele destacou, inicialmente, que essa Medida Provisória tinha por objetivo tratar de um assunto relevante, ou seja, "a necessidade de reexaminarmos a acessibilidade dos Tribunais Superiores e recuperarmos a memória da República”411.

Ponderou, contudo, sobre a efetiva urgência da questão, especialmente considerando tratar-se de um sistemática tal, cuja eficácia dependeria da manifestação de vontade, em data incerta, de um outro órgão colegiado, no caso, o C. TST; na prática, tudo

\footnotetext{
${ }^{409}$ SUPREMO TRIBUNAL FEDERAL. Disponível em: $<$ http://www.stf.jus.br/portal/jurisprudencia/listarJurisprudencia.asp?s1=\%28ADI\%24\%2ESCLA\%2E+E+2 $527 \% 2 \mathrm{ENUME} \% 2 \mathrm{E} \% 29+\mathrm{OU}+\% 28 \mathrm{ADI} \% 2 \mathrm{EACMS} \% 2 \mathrm{E}+\mathrm{ADJ} 2+2527 \% 2 \mathrm{EACMS} \% 2 \mathrm{E} \% 29 \&$ base=baseAc ordaos>. Acesso em: 11 out. 2010.

${ }^{410}$ SUPREMO TRIBUNAL FEDERAL. Disponível em: http://redir.stf.jus.br/paginador/paginador.jsp?docTP=AC\&docID=495496>. Acesso em: 11 out. 2010.

${ }^{411}$ SUPREMO TRIBUNAL $\quad$ FEDERAL. $\quad$ Disponível em: http://redir.stf.jus.br/paginador/paginador.jsp?docTP=AC\&docID=495496>. Acesso em: 11 out. 2010.
} 
isso desnaturaria a própria urgência constitucional necessária para a edição de medida provisória, tendo este Ministro se expressado nos seguintes termos:

Se a matéria tem urgência, o ato que cria um instrumento tem que solucionar, atender e atacar os problemas para os quais eles vigem, por meio de soluções; não se pode estabelecer um tempo. ${ }^{412}$

Após pedir vista, o Min. Maurício Corrêa propôs, também, viesse a ser suspensa a vigência dos artigos $1^{\circ}$ e $2^{\circ}$ da Medida Provisória 2226/01.

Salientou, em primeiro lugar, prevalecer certa tolerabilidade do E. STF quanto à faculdade subjetiva de o Presidente da República valer-se de medidas provisórias, partindo-se da perspectiva que somente a ele incumbe mensurar a existência de relevância e urgência da matéria disciplinada. No entanto, tal circunstância não seria capaz de impedir a contenção, pelo E. STF, de eventual abuso.

No caso em análise, a relevância da matéria seria indiscutível, no entendimento do Ministro. Urgência, por sua vez, não haveria, ainda que por fundamento diverso daquele usado pelo julgador antecedente, pois a ela é incompatível com a ausência de funcionalidade do instituto regulado. Tudo indicava que urgência houve só na circunstância de se editar a Medida Provisória antes da aprovação da EC 32/01, que vedou o uso dessa espécie normativa para regular matérias relativas a direito processual.

Isso não bastasse, destacou que a imposição de norma processual indefinida e imprecisa, no caso, o instituto da transcendência, acabava por comprometer o devido processo legal, seja por se inviabilizar o direito de defesa, seja por abrir-se a possibilidade de, idênticas as circunstâncias fáticas e a situação das partes, um recurso vir a ser admitido e outro, não.

Após novo pedido de vista, proferiu voto o Min. Sepúlveda Pertence, o qual salientou a inexistência do requisito urgência, mormente em razão de haver necessidade de regulamentação posterior pelo C. TST. Chamou a atenção, outrossim, para o fato de a EC 32/01, ao proibir o uso da medida provisória para regular matéria processual, ainda que não atingindo no ponto a norma em questão, dever servir de parâmetro interpretativo, a ser

\footnotetext{
${ }^{412}$ SUPREMO TRIBUNAL TEDERAL. Disponível em: http://redir.stf.jus.br/paginador/paginador.jsp?docTP=AC\&docID=495496>.Acesso em: 11 out. 2010.
} 
utilizado pelo E. STF. Acompanhou, assim, os votos dos Ministros Nelson Jobim e Maurício Corrêa, no que tange à suspensão dos dois primeiros artigos da Medida Provisória 2226/01.

Por fim, o Min. Marco Aurélio divergiu do voto da Relatora quanto à fixação de transcendência por medida provisória, opinando pelo deferimento da cautelar. Lembrou que a Corte já havia reiterado posicionamento no sentido de a EC 32/01 possuir contornos meramente pedagógicos, uma vez que, antes de sua edição, seria inadequado o trato de matéria processual por via de medida provisória, diante da sua natureza precária e efêmera.

Ao final, tendo sido vencidos os Ministros Nelson Jobim, Maurício Corrêa, Sepúlveda Pertence e Marco Aurélio, prevaleceu, em síntese, o entendimento de que não teria havido ofensa ao art. 62 da Constituição Federal, quanto à urgência e à relevância para a edição da medida, em razão da sobrecarga causada pelos inúmeros recursos repetitivos em tramitação no TST, assim como a imperiosa necessidade de uma célere e qualificada prestação jurisdicional, exatamente como constou da ementa antes transcrita.

Importa ressaltar que, inexplicavelmente, prevaleceu o argumento segundo o qual, embora tratasse de matéria processual, a Medida Provisória 2.226/01 havia sido editada em 05.09.2001, antes, portanto, do advento da Emenda Constitucional 32, de 11.09.2001, por isso que não teria a mácula de inconstitucionalidade, ou seja, dela teria escapado, por mera razão temporal.

Noutras palavras, malgrado quatro Ministros tenham feito menção à entendimento anterior no sentido da impossibilidade de se legislar matéria processual por Medida Provisória, superou-se esse entrave pela simples constatação do momento em que nasceu essa medida legal, ou seja, apenas seis dias antes da EC 32/01, argumento que se funda na mera legalidade, ignorando-se o viés constitucional da matéria discutida, que não era inédita na Suprema Corte.

De fato, dentre outros motivos que teve o Poder Constituinte Derivado, essa EC 32/01 veio luz para que fosse feita adequação do texto constitucional à jurisprudência antes já firmada pelo próprio E. Supremo Tribunal Federal, quando do julgamento da ADI 1910MC, em 22/04/99, não aceitando que medida provisória disciplinasse temas processuais. 
Relembre-se que o Conselho Federal da Ordem dos Advogados do Brasil, quase três anos antes (1999), bateu às portas da Suprema Corte para questionar a viabilidade constitucional das Medidas Provisórias 1703/98 e 1798-3/99, editadas e reeditadas várias vezes, que alteravam o art. 188, I do CPC, duplicando os prazos para ajuizamento de ação rescisória, quando proposta pela União, Estados, DF, Municípios ou o Ministério Público, bem como acrescentando novo inciso ao art. 485 do CPC, que trazia nova hipótese de rescindibilidade das decisões.

Pois bem, dentre outros argumentos, o E. Supremo Tribunal Federal concedeu a cautelar requerida, para suspender a eficácia dos artigos impugnados, exatamente porque a medida provisória não seria meio apto a regular matéria processual. Assim foi redigida a ementa do caso paradigma, ora invocado (ADI 1910-MC):

EMENTA: Ação rescisória: argüição de inconstitucionalidade de medidas provisórias (MPr 1.703/98 a MPr 1798-3/99) editadas e reeditadas para a) alterar o art. 188, I, CPC, a fim de duplicar o prazo para ajuizar ação rescisória, quando proposta pela União, os Estados, o DF, os Municípios ou o Ministério Público; b) acrescentar o inciso X no art. 485 CPC, de modo a tornar rescindível a sentença, quando "a indenização fixada em ação de desapropriação direta ou indireta for flagrantemente superior ou manifestamente inferior ao preço de mercado objeto da ação judicial": preceitos que adoçam a pílula do edito anterior sem lhe extrair, contudo, o veneno da essência: medida cautelar deferida. 1. Medida provisória: excepcionalidade da censura jurisdicional da ausência dos pressupostos de relevância e urgência à sua edição: raia, no entanto, pela irrisão a afirmação de urgência para as alterações questionadas à disciplina legal da ação rescisória, quando, segundo a doutrina e a jurisprudência, sua aplicação à rescisão de sentenças já transitadas em julgado, quanto a uma delas - a criação de novo caso de rescindibilidade - é pacificamente inadmissível e quanto à outra - a ampliação do prazo de decadência - é pelo menos duvidosa: razões da medida cautelar na ADIn 1753, que persistem na presente.

2. Plausibilidade, ademais, da impugnacãa da utilização de medidas provisórias para alterar a disciplina legal do processo, à vista da definitividade dos atos nele praticados, em particular, de sentença coberta pela coisa julgada. (g.n.)

3. A igualdade das partes é imanente ao procedural due process of law; quando uma das partes é o Estado, a jurisprudência tem transigido com alguns favores legais que, além da vetustez, tem sido reputados não arbitrários por visarem a compensar dificuldades da defesa em juízo das entidades públicas; se, ao contrário, desafiam a medida da razoabilidade ou da proporcionalidade, caracterizam privilégios inconstitucionais: parece ser esse o caso na parte em que a nova medida provisória insiste, quanto ao prazo de decadência da ação rescisória, no favorecimento 
unilateral das entidades estatais, aparentemente não explicável por diferenças reais entre as partes e que, somadas a outras vantagens processuais da Fazenda Pública, agravam a consequiência perversa de retardar sem limites a satisfação do direito do particular já reconhecido em juízo.

4. No caminho da efetivação do due process of law - que tem particular relevo na construção sempre inacabada do Estado de direito democrático - a tendência há de ser a da gradativa superação dos privilégios processuais do Estado, à custa da melhoria de suas instituições de defesa em juízo, e nunca a da ampliação deles ou a da criação de outros, como é preciso dizê-lo - se tem observado neste decênio no Brasil. ${ }^{413}$

O Relator, Min. Sepúlveda Pertence, no seu voto fez menção explícita à inadmissibilidade da medida provisória como meio de regular matéria processual, o que também está consignado no trecho destacado da ementa. Assim constou da fundamentação, ou seja, não se trata de mera alusão obiter dicta:

O caso mostra ademais a extrema dificuldade, em geral, da admissão da medida provisória para alterar a disciplina legal do processo. Impressiona-me a agudeza das observações a respeito do Prof. Marcos Bernardes de Mello, da Universidade Federal de Alagoas, evocadas na inicial:

"Como é indiscutível, não há atos processuais provisórios ou condicionados. A característica própria dos atos processuais é a sua definitividade. Por isso, as leis processuais têm vigência imediata, mas sempre ad futurum, jamais retroagindo para modificar atos processuais já praticados validamente.

Ora, em relação às medidas provisórias, a sua aprovação pelo Congresso Nacional dentro do trintídio constitucional opera uma condição resolutiva expressa quanto aos seus efeitos, pois, como já vimos, estes se resolvem ex tunc se não sobrevier a sua conversão em lei. Por isso, seus efeitos são sempre condicionados.

Como decorrência dessa condicionalidade e conseqüente provisoriedade dos seus efeitos, medida provisória não pode, logicamente, regular matéria processual em face de sua definitividade."

Não me comprometo de logo com a tese radical, de que não necessito, na espécie, para reafirmar o peso da argüição em mesa; mas são considerações que reclamarão reflexão detida em casos futuros. ${ }^{414}$

\footnotetext{
${ }^{413}$ SUPREMO TRIBUNAL FEDERAL. em: $<$ http://redir.stf.jus.br/paginador/paginador.jsp?docTP=AC\&docID=347324>. Acesso em: 12 out. 2010.

${ }^{414}$ Id. Ibid.
} 
Uma vez estabelecido este precedente pelo E. STF ${ }^{415}$, ainda em 1999 , causa estranheza que, mais de oito anos depois, a própria Corte, ao terminar o julgamento da medida cautelar da ADI n. ${ }^{\circ}$ 2.527, em 2007, dele não tenha se lembrado, mormente porque, quatro anos antes do término da apreciação da cautelar, em 01.10.2003, no julgamento da Reclamação $\mathrm{n}^{\circ} 1.987$, foi firmado entendimento no sentido de que o caráter vinculante das decisões do Supremo Tribunal estendia-se, inclusive, aos motivos determinantes e norteadores do julgamento. E, como se sabe, precedente firmado no Plenário do Supremo é coisa muito séria e sua observância é sempre perseguida, bastando mencioná-lo, evidentemente quando demonstrada sua pertinência ao caso (cfr. nota de rodapé 381).

Pois bem, na referida Reclamação no 1987, proposta pelo Governador do DF, discutiu-se o suposto desrespeito à decisão proferida nos autos da ADI 1662.

O Relator, Min. Maurício Corrêa, após deferir a liminar requerida pelo Distrito Federal, votou no sentido de conhecer da reclamação e julgá-la procedente, salientando o risco de incentivar-se o descumprimento sistemático das decisões da mais alta Corte do país, em especial as que detém eficácia vinculante. Dos argumentos de Sua Excelência extraem-se os seguintes:

Oportuna a lição da doutrina de José Frederico Marques: "O Supremo Tribunal, sob pena de se comprometerem as elevadas funções que a Constituição lhe conferiu, não pode ter seus julgados desobedecidos (por meios diretos ou oblíquos), ou vulnerada sua competência. Trata-se (...) de medida de Direito Processual Constitucional, porquanto tem como causa finalis assegurar os poderes e prerrogativas que ao Supremo Tribunal foram dados pela Constituição da República." (apud Celso de Mello, RCLQO 1.723-CE, DJ 06/0401 - grifei). Como visto, revela-se de fundamental importância o resguardo à eficácia das decisões tomadas pelo Supremo Tribunal Federal, sendo inadmissível a desobediência perpetrada contra a exegese constitucional consagrada em seus julgados, mesmo naquelas hipóteses em que a violação ocorre de forma oblíqua. ${ }^{416}$

\footnotetext{
${ }^{415}$ Tenha-se em conta fundamental diretriz adotada pelo Supremo Tribunal Federal: o precedente é fixado a partir do julgamento e, não, da publicação do acórdão, tanto assim que, em vários processos submetidos à Suprema Corte, não se faz alusão à data da publicação, mas, ao próprio boletim Informativo do STF, sendo nesse sentido, o que constou das ementas do $\mathrm{HC}^{\circ}$ 95969, DJE 12/06/09 (menciona o Informativo 457/STF) e $\mathrm{HC} \mathrm{n}^{\circ}$ 85877, DJE 16/04/09, (menciona o Informativo 534/STF), RE no 541627, DJE 21/11/08, (menciona o Informativo 450/STF) ADI 3615, DJ 09/03/07, (menciona o Informativo 316/STF).

${ }^{416}$ SUPREMO TRIBUNAL $\quad$ FEDERAL. $<$ http://redir.stf.jus.br/paginador/paginador.jsp?docTP=AC\&docID=87272>. Acesso em: 17 out. 2010.
} 
Observou ainda que a desobediência deve ser aferida em relação ao conteúdo essencial da decisão da Corte, independente de haver invocação ou, não, ao ato normativo originalmente invalidado pelo E. STF.

Seguiram-se à leitura do voto do Relator vigorosos debates, centrados, em especial, na possibilidade de extensão do efeito vinculante aos motivos da decisão.

O Min. Celso de Mello, na sua manifestação conhecendo da reclamação, enfatizou a integridade, a autoridade e a eficácia subordinante dos comandos que emergem dos atos decisórios do E. STF.

Em seguida, proferiu o Min. Gilmar Mendes voto paradigmático, no qual analisou detidamente por que as razões determinantes de uma decisão possuem efeito vinculante, posição que acabou prevalecendo, desde então, no âmbito da Corte.

Em verdade, o efeito vinculante decorre do particular papel políticoinstitucional desempenhado pela Corte ou pelo Tribunal Constitucional, que deve zelar pela observância estrita da Constituição nos processos especiais concebidos para solver determinadas e específicas controvérsias constitucionais. Esse foi o entendimento adotado pelo Supremo Tribunal na $\mathrm{ADC} 4$, ao reconhecer efeito vinculante à decisão proferida em sede de cautelar, a despeito do silêncio do texto constitucional. Não foi outro o entendimento do legislador infraconstitucional ao conferir efeito vinculante às decisões proferidas em ação direta de inconstitucionalidade.

\section{(...)}

Vale ressaltar que o alcance do efeito vinculante das decisões não pode estar limitado à sua parte dispositiva, devendo, também, considerar os chamados "fundamentos determinantes". Nesse sentido, trago à reflexão algumas observações sobre os limites objetivos do efeito vinculante:

“(...) Problema de inegável relevo diz respeito aos limites objetivos do efeito vinculante, isto é, à parte da decisão que tem efeito vinculante para os órgãos constitucionais, tribunais e autoridades administrativas. Em suma, indaga-se, tal como em relação à coisa julgada e à força de lei, se o efeito vinculante está adstrito à parte dispositiva da decisão ou se ele se estende também aos chamados fundamentos determinantes, ou, ainda, se o efeito vinculante abrange também as considerações marginais, as coisas ditas de passagem, isto é, os chamados obiter dicta (Cf. Maunz, in Maunz, et. al., BverfGG, cit., § 31, I, n. 16).

Enquanto em relação à coisa julgada e à força da lei domina a idéia de que elas hão de se limitar à parte dispositiva da decisão, sustenta o Tribunal Constitucional alemão que o efeito vinculante se estende, igualmente, aos fundamentos determinantes da decisão (...). 
Segundo esse entendimento, a eficácia da decisão do Tribunal transcende o caso singular, de modo que os princípios dimanados da parte dispositiva e dos fundamentos determinantes sobre a interpretação da Constituição devem ser observados por todos os tribunais e autoridades nos casos futuros (BverfGE 19, 377).

\section{(...)}

Assim, propõe Vogel que a coisa julgada ultrapasse os estritos limites da parte dispositiva, abrangendo também a "norma decisória concreta" (Klaus Vogel, Rechtskraft und Cesetzeskraft, in BverfG und GG, cit., v. 1, p. 568 (589). A norma decisória concreta seria aquela "idéia jurídica subjacente à formulação contida na parte dispositiva, que, concebida de forma geral, permite não só a decisão do caso concreto, mas também a decisão de casos semelhantes".

\section{(...)}

É certo, por outro lado, que a limitação do efeito vinculante à parte dispositiva da decisão tornaria de todo despiciendo esse instituto, uma vez que ele pouco acrescentaria aos institutos da coisa julgada a da força de lei. Ademais tal redução diminuiria significativamente a contribuição do Tribunal para a preservação e desenvolvimento da ordem constitucional (Brun-Otto Bryde, Verfassungsentwicklung, cit., p. 420)." (Controle Concentrado de Constitucionalidade, Martins, Ives Gandra da Silva e Mendes, Gilmar Ferreira. Ed. Saraiva, 2001, p. 338 a 341).

Assim, adotada a idéia de que o efeito vinculante alcança os fundamentos determinantes da decisão, afigura-se necessário, nesse primeiro exame, considerar o parâmetro interpretativo fixado por esta Corte na ADI 1.662.

\section{(...)}

Assinale-se que a aplicação dos fundamentos determinantes de um leading case em hipóteses semelhantes tem-se verificado, entre nós, até mesmo no controle de constitucionalidade das leis municipais.

Em um levantamento precário, pude constatar que muitos juízes desta Côrte têm, constantemente, aplicado em caso de declaração de inconstitucionalidade $\mathrm{o}$ precedente fixado a situações idênticas reproduzidas em leis de outros municípios. ${ }^{417}$

Ao final, o E. STF optou por conhecer da reclamação, vencidos, no particular, os Ministros Sepúlveda Pertence, Carlos Britto e Marco Aurélio. No mérito, vencido o Min. Marco Aurélio, julgou-se procedente a reclamação, cuja ementa é a seguinte:

\footnotetext{
${ }^{417}$ SUPREMO TRIBUNAL FEDERAL. Disponível em: <http://redir.stf.jus.br/paginador/paginador.jsp?docTP=AC\&docID=87272>. Acesso em: 17 out. 2010.
} 
EMENTA: RECLAMAÇÃO. CABIMENTO. AFRONTA À DECISÃO PROFERIDA NA ADI 1662-SP. SEQÜESTRO DE VERBAS PÚBLICAS. PRECATÓRIO. VENCIMENTO DO PRAZO PARA PAGAMENTO. EMENDA CONSTITUCIONAL 30/00. PARÁGRAFO $2^{\circ}$ DO ARTIGO 100 DA CONSTITUIÇÃO FEDERAL. 1. Preliminar. Cabimento. Admissibilidade da reclamação contra qualquer ato, administrativo ou judicial, que desafie a exegese constitucional consagrada pelo Supremo Tribunal Federal em sede de controle concentrado de constitucionalidade, ainda que a ofensa se dê de forma oblíqua.2. (...) ${ }^{418}$

Em suma, a partir do julgamento dessa Reclamação 1.987, em 2003, fixou-se no E. STF o entendimento de que os fundamentos determinantes da decisão de constitucionalidade ou de inconstitucionalidade, àquela altura, já possuíam eficácia contra todos e efeito vinculante, ou seja, adquirem o espírito e a forma de precedentes obrigatórios do Tribunal Máximo, o que, aliás, já estava previsto na EC 03/93 e foi confirmado pela EC 45/04.

Este entendimento da Suprema Corte foi reiterado no julgamento da Reclamação 2363, ocorrido em 23 de outubro de 2003, cuja ementa é a seguinte:

E M E N T A: RECLAMAÇÃO. 2. Seqüestro de recursos do Município de Capitão Poço. Débitos trabalhistas. 3. Afronta à autoridade da decisão proferida na ADI 1662. 4. Admissão de seqüestro de verbas públicas somente na hipótese de quebra da ordem cronológica. Não equiparação às situações de não-inclusão da despesa no Orçamento. 5. Efeito vinculante das decisões proferidas em ação direta de inconstitucionalidade. 6. Eficácia que transcende o caso singular. 7. Alcance do efeito vinculante que não se limita à parte dispositiva da decisão. 8. Aplicação das razões determinantes da decisão proferida na ADI 1662. 9. Reclamação que se julga procedente. ${ }^{419}$

Insista-se, portanto, que, tendo o julgamento da medida cautelar da ADI 2.527 só terminado em 2007, quando já em pleno vigor a EC 45/04, causa espécie haver a maioria dos Ministros desconsiderado a força normativa e vinculante do que decidido na ADI

\footnotetext{
${ }^{418}$ Citação parcial da ementa, naquilo que pertine à discussão da eficácia vinculante dos fundamentos das decisões tomadas pelo Plenário do Supremo Tribunal Federal, nos julgamentos de ADI, sítio do SUPREMO TRIBUNAL FEDERAL. Disponível em: <http://www.stf.jus.br/portal/jurisprudencia/listarJurisprudencia.asp?s1=\%28Rcl\%24\%2ESCLA\%2E+E+1 987\%2ENUME\%2E\%29+OU+\%28Rc1\%2EACMS\%2E+ADJ2+1987\%2EACMS\%2E\%29\&base=baseAc ordaos>. Acesso em: 27 out. 2010.

${ }^{419}$ Citação integral da ementa, encontrada no sítio do SUPREMO TRIBUNAL FEDERAL. Disponível em: $<$ http://www.stf.jus.br/portal/jurisprudencia/listarJurisprudencia.asp?s1=\%28Rc1\%24\%2ESCLA\%2E+E+2 $363 \% 2 \mathrm{ENUME} \% 2 \mathrm{E} \% 29+\mathrm{OU}+\% 28 \mathrm{Rcl} \% 2 \mathrm{EACMS} \% 2 \mathrm{E}+\mathrm{ADJ} 2+2363 \% 2 \mathrm{EACMS} \% 2 \mathrm{E} \% 29 \& \mathrm{base}=\mathrm{baseAc}$ ordaos>. Acesso em: 27 out. 2010.
} 
1.910-MC e nas Reclamações 1987 e 2363 e, doutro tanto, haver fechado os olhos para o que diz $\S 2^{\circ}$ do art. 102 da Carta Política, também deslembrando-se do entendimento cristalizado na questão de ordem da (antiga) ADC $\mathrm{n}^{\circ} 4$, sobre a possibilidade e a constitucionalidade da concessão de medida liminar nas ações de controle concentrado de constitucionalidade, vale dizer, liminar com eficácia erga omnes e efeito vinculante, antes da decisão final de mérito, ou seja, ainda que se trate de juízo preliminar. ${ }^{420}$

Nessas circunstâncias, torna-se difícil conceber como o Supremo Tribunal Federal, em 2007, tenha podido aceitar como adequado o uso de medida provisória para veicular alteração ou criação de norma processual.

Diga-se mais ainda: a jurisprudência do STF tem admitido efeito vinculante até mesmo em decisões proferidas em sede de controle difuso (julgamento de RE), fenômeno que Guilherme José Braz de Oliveira denomina tendência de objetivação do recurso extraordinário, pois a tese que foi definida e aceita "poderia ser aplicada a casos

${ }^{420}$ EMENTA: AÇÃO DIRETA DE CONSTITUCIONALIDADE DO ART. $1^{\circ}$ DA LEI N 9.494, DE 10.09.1997, QUE DISCIPLINA A APLICAÇÃO DA TUTELA ANTECIPADA CONTRA A FAZENDA PÚBLICA. MEDIDA CAUTELAR: CABIMENTO E ESPÉCIE, NA A.D.C. REQUISITOS PARA SUA CONCESSÃO. 1. Dispõe o art. $1^{\circ}$ da Lei n..$^{\circ} 9.494$, da 10.09.1997: "Art. $1^{\circ}$. Aplica-se à tutela antecipada prevista nos arts. 273 e 461 do Código de Processo Civil, o disposto nos arts $5^{\circ}$ e seu parágrafo único e art. $7^{\circ}$ da Lei n..$^{\circ} 4.348$, de 26 de junho de 1964 , no art. $1^{\circ}$ e seu $\S 4^{\circ}$ da Lei n. ${ }^{\circ} 5.021$, de 09 de junho de 1966 , e nos arts. $1^{\circ}, 3^{\circ}$ e $4^{\circ}$ da Lei n. ${ }^{\circ} 8.437$, de 30 de junho de 1992." 2. Algumas instâncias ordinárias da Justiça Federal têm deferido tutela antecipada contra a Fazenda Pública, argumentando com a inconstitucionalidade de tal norma. Outras instâncias igualmente ordinárias e até uma Superior - o S.T.J. - a têm indeferido, reputando constitucional o dispositivo em questão. 3. Diante desse quadro, é admissível Ação Direta de Constitucionalidade, de que trata a $2^{\mathrm{a}}$ parte do inciso I do art. 102 da C.F., para que o Supremo Tribunal Federal dirima a controvérsia sobre a questão prejudicial constitucional. Precedente: A.D.C. n 1. Art. 265, IV, do Código de Processo Civil. 4. As decisões definitivas de mérito, proferidas pelo Supremo Tribunal Federal, nas Ações Declaratórias de Constitucionalidade de lei ou ato normativo federal, produzem eficácia contra todos e até efeito vinculante, relativamente aos demais órgãos do Poder Judiciário e ao Poder Executivo, nos termos do art. 102, $\S 2^{\circ}$, da C.F. 5. Em Ação dessa natureza, pode a Corte conceder medida cautelar que assegure, temporariamente, tal força e eficácia à futura decisão de mérito. E assim é, mesmo sem expressa previsão constitucional de medida cautelar na A.D.C., pois o poder de acautelar é imanente ao de julgar. Precedente do S.T.F.: RTJ-76/342. 6. Há plausibilidade jurídica na argüição de constitucionalidade, constante da inicial ("fumus boni iuris"). Precedente: ADIMC 1.576-1. 7. Está igualmente atendido o requisito do "periculum in mora", em face da alta conveniência da Administração Pública, pressionada por liminares que, apesar do disposto na norma impugnada, determinam a incorporação imediata de acréscimos de vencimentos, na folha de pagamento de grande número de servidores e até o pagamento imediato de diferenças atrasadas. E tudo sem o precatório exigido pelo art. 100 da Constituição Federal, e, ainda, sob as ameaças noticiadas na inicial e demonstradas com os documentos que a instruíram. 8. Medida cautelar deferida, em parte, por maioria de votos, para se suspender, "ex nunc", e com efeito vinculante, até o julgamento final da ação, a concessão de tutela antecipada contra a Fazenda Pública, que tenha por pressuposto a constitucionalidade ou inconstitucionalidade do art. $1^{\circ}$ da Lei n. ${ }^{\circ} 9.494$, de 10.09.97, sustando-se, igualmente "ex nunc", os efeitos futuros das decisões já proferidas, nesse sentido. (g.n) Ementa extraída do sítio do SUPREMO TRIBUNAL FEDERAL.

Disponível

em: $<$ http://www.stf.jus.br/portal/jurisprudencia/listarJurisprudencia.asp?s1=\%28ADC\%24\%2ESCLA\%2E+E+ 4\%2ENUME $\% 2 \mathrm{E} \% 29+\mathrm{OU}+\% 28 \mathrm{ADC} \% 2 \mathrm{EACMS} \% 2 \mathrm{E}+\mathrm{ADJ} 2+4 \% 2 \mathrm{EACMS} \% 2 \mathrm{E} \% 29 \&$ base=baseAcorda os>. Acesso em: 29 out. 2010. 
semelhantes, ainda que esse julgamento não gere a edição de uma súmula (vinculante ou não) e mesmo sem a instauração de um incidente específico de arguição de inconstitucionalidade, cuja decisão é passível de produzir eficácia erga omnes (arts. 101 e 178 do Regimento Interno do Supremo Tribunal Federal, c.c. artigo 52,X, e artigo 481, parágrafo único do Código de Processo Civil)."421

A esse respeito (e porque interessa ao deslinde do julgamento final da ADI que trata da transcendência) cabe conferir a ementa da ADI 3345/DF, relatada pelo Min. Celso de Mello, julgada em 28 de maio de 2005:

$(\ldots$.

EFEITO TRANSCENDENTE DOS FUNDAMENTOS DETERMINANTES DO JULGAMENTO DO RE 197.917/SP INTERPRETAÇÃO DO INCISO IV DO ART. 29 DA CONSTITUIÇÃ̃O. - O Tribunal Superior Eleitoral, expondo-se à eficácia irradiante dos motivos determinantes que fundamentaram o julgamento plenário do RE 197.917/SP, submeteu-se, na elaboração da Resolução n. ${ }^{\circ}$ 21.702/2004, ao princípio da força normativa da Constituição, que representa diretriz relevante no processo de interpretação concretizante do texto constitucional. - O TSE, ao assim proceder, adotou solução, que, legitimada pelo postulado da força normativa da Constituição, destinavase a prevenir e a neutralizar situações que poderiam comprometer a correta composição das Câmaras Municipais brasileiras, considerada a existência, na matéria, de grave controvérsia jurídica resultante do ajuizamento, pelo Ministério Público, de inúmeras ações civis públicas em que se questionava a interpretação da cláusula de proporcionalidade inscrita no inciso IV do art. 29 da Lei Fundamental da República. A FORÇA NORMATIVA DA CONSTITUIÇÃO DA REPÚBLICA E O MONOPÓLIO DA ÚLTIMA PALAVRA, PELO SUPREMO TRIBUNAL FEDERAL, EM MATÉRIA DE INTERPRETAÇÃO CONSTITUCIONAL. - O exercício da jurisdição constitucional - que tem por objetivo preservar a supremacia da Constituição - põe em evidência a dimensão essencialmente política em que se projeta a atividade institucional do Supremo Tribunal Federal, pois, no processo de indagação constitucional, assenta-se a magna prerrogativa de decidir, em última análise, sobre a própria substância do poder. No poder de interpretar a Lei Fundamental, reside a prerrogativa extraordinária de (re)formulá-la, eis que a interpretação judicial acha-se compreendida entre os processos informais de mutação constitucional, a significar, portanto, que "A Constituição está em elaboração permanente nos

\footnotetext{
${ }^{421}$ OLIVEIRA, Guilherme José Braz de., op. cit. p. 71. Este Autor anota à fl. 81 que repercussão geral "fortalece de certa maneira essa tendência, no sentido de tornar os julgamentos do Supremo Tribunal Federal verdadeiros precedentes". Eis, de fato, uma maneira de se eliminarem casos e mais casos de recursos que discutem teses idênticas, de sorte que teria eficácia vinculante as decisões de controle abstrato e difuso. Também este sistema poderia ser útil nos Tribunais Superiores, o que seria viabilizado pelas Súmulas Vinculantes ou Impeditivas de recurso e pelos julgamentos Plenários ou de Órgão Especial, sempre definidas em lei. Sabe-se que na continuação da Reforma do Judiciário prevê-se a instituição de Súmulas Vinculantes para os Tribunais Superiores, mas não se sabe quando isso chegará a bom termo.
} 
Tribunais incumbidos de aplicá-la". Doutrina. Precedentes. A interpretação constitucional derivada das decisões proferidas pelo Supremo Tribunal Federal - a quem se atribuiu a função eminente de "guarda da Constituição" (CF, art. 102, "caput") - assume papel de essencial importância na organização institucional do Estado brasileiro, a justificar o reconhecimento de que o modelo político-jurídico vigente em nosso País confere, à Suprema Corte, a singular prerrogativa de dispor do monopólio da última palavra em tema de exegese das normas inscritas no texto da Lei Fundamental. ${ }^{422}$

Em síntese, é inconteste que a atuação do Supremo Tribunal Federal, na forma do caput do art. 102 da CF, exige que ele busque a preservação da força normativa da Constituição, "que resulta da indiscutível supremacia, formal e material, de que se revestem as normas constitucionais, cuja integridade, eficácia e aplicabilidade, por isso mesmo, hão de ser valorizadas, em face de sua precedência, autoridade e grau hierárquico", tal como observou Elainy Morais Gonçalves. ${ }^{423}$

Finalmente, não se ignora que o art. $2^{\circ}$ da EC 32, de 11 de setembro de 2001, estabeleceu que as "medidas provisórias editadas em data anterior à publicação desta emenda continuam em vigor até que medida provisória ulterior as revogue explicitamente ou até deliberação definitiva do Congresso Nacional”.

No entanto, à toda evidência, o que este excepcional preceito emanado do Poder Constituinte Derivado quis dizer não pode ultrapassar os limites maiores e incontrastáveis da Carta Constitucional, a saber, que se vive em Estado Democrático de Direito no qual o Executivo não exerce poder absoluto ou superior ao Legislativo e ao Judiciário. Por isso é que Luiz Manoel Gomes Júnior vislumbrou inconstitucionalidade da própria Emenda Constitucional n. ${ }^{\circ} 32 / 01$, pois, se o Constituinte originário não outorgou efeito por tempo indefinido às medidas provisórias, que são, "por essência de duração limitada.," ${ }^{424}$ esse efeito não poderia ser atribuído à MP 2226/01.

\footnotetext{
${ }^{422}$ Citação parcial da ementa da ADI 3345, naquilo que pertine aos efeitos vinculantes dos fundamentos de decisão proferida em julgamento de recurso extraordinário que trata de tema constitucional. SUPREMO TRIBUNAL FEDERAL. Disponível em: <http://www.stf.jus.br/portal/jurisprudencia/listarJurisprudencia.asp?s1=\%28ADI\%24\%2ESCLA\%2E+E+3 $345 \% 2 \mathrm{ENUME} \% 2 \mathrm{E} \% 29+\mathrm{OU}+\% 28 \mathrm{ADI} \% 2 \mathrm{EACMS} \% 2 \mathrm{E}+\mathrm{ADJ} 2+3345 \% 2 \mathrm{EACMS} \% 2 \mathrm{E} \% 29 \&$ base $=$ baseAc ordaos>. Acesso em: 27 out. 2010.

${ }^{423}$ GONÇALVES, Elainy Morais. A transcendência dos motivos determinantes e a força normativa da Constituição. BDJur, Brasília, DF, 15 abr. 2008. Disponível em: <http://bdjur.stj.gov.br/dspace/handle/2011/16869>. Acesso em: 29 out. 2010.

${ }^{424}$ GOMES JUNIOR, Luiz Manoel. op. cit., p. 1302.
} 
Destarte, malgrado o generoso elastecimento da vigência daquelas medidas provisórias anteriores à EC 32, quiçá em razão do quorum diferenciado próprio das emendas, maior, que foi atingido para a respectiva aprovação, não pode significar, todavia, que aquelas medidas escaparam de ser apreciadas pelo Congresso Nacional, locus primordial e essencial da gênese legislativa. ${ }^{425}$

As medidas provisórias têm força de lei, apenas, e hão se ser submetidas à análise do Legislativo, tal como sempre decorreu do art. 62 da Carta Constitucional (com qualquer redação, primitiva, anterior ou atual), haja vista a condição resolutiva que é da essência desse tipo normativo excepcional.

Outra não é a lição de Gilmar Ferreira Mendes, Inocêncio Mártires Coelho e Paulo Gustavo Gonet Branco, segundo os quais a EC 32/01 eliminou a necessidade de reedição das medidas provisórias anteriores à sua vigência "para permanecer em vigor e assim ficarão até que o Congresso Nacional se manifeste - rejeitando ou editando lei em sentido colidente com as suas normas - ou até que o Presidente da República edite outra medida provisória que as altere" ${ }^{426}$, ou seja, em princípio, ficou inalterado o mais elementar sistema de revogação de lei, na exata forma do que dispõe o art. $2^{\circ}$ da Lei de Introdução ao Código Civil, conquanto, insista-se, a medida provisória não seja lei em sentido técnico, pendente que é de condição, tendo apenas sua força.

Aqui, todavia, há um detalhe peculiar e importante: visto que MP 2226/01 cuida de matéria processual, evidentemente, que o Poder Executivo não poderá editar outra medida provisória!!!

\footnotetext{
${ }^{425}$ A propósito, confira-se o teor do voto proferido pelo Ministro Celso de Mello, no julgamento da MCADC11, TP 28.03.2007, a respeito da excepcional competência atribuída ao Presidente da República para editar Medida Provisória, que não pode ser abusiva. "Cabe advertir, por isso mesmo, que a utilização excessiva das medidas provisórias minimiza, perigosamente, a importância político-institucional do Poder Legislativo, pois suprime a possibilidade de prévia discussão parlamentar de matérias que, ordinariamente, estão sujeitas ao poder decisório do Congresso Nacional. Na realidade, a expansão do poder presidencial, em tema de desempenho da função normativa primária - além de viabilizar a possibilidade de uma preocupante ingerência do Chefe do Pode Executivo da União tratamento unilateral de questões, que, historicamente, sempre pertenceram à esfera de atuação institucional dos corpos legislativos - , introduz fator de desequilíbrio sistêmico que atinge, afeta e desconsidera a essência da ordem democrática, cujos fundamentos, apoiados em razões de garantia política e de segurança jurídica dos cidadãos, conferem justificação teórica ao princípio da reserva de Parlamento e ao postulado da separação de poderes. Cumpre não desconhecer, neste ponto, que é o Parlamento, no regime da separação de poderes, o único órgão estatal investido de legitimidade constitucional para elaborar democraticamente, as leis do Estado." (destaques do original) Extraído do sítio do STF. SUPREMO TRIBUNAL FEDERAL. Disponível em: $<$ http://redir.stf.jus.br/paginador/paginador.jsp?docTP=AC\&docID=469584>. Acesso em: 14 dez. 2010.

${ }^{426}$ MENDES, Gilmar Ferreira; COELHO, Inocêncio Mártires; BRANCO, Paulo Gustavo Gonet. op. cit., p. 900.
} 
Nessas circunstâncias, portanto, a EC 32/01 implicou distorção pior e manifesta com relação à própria MP 2226/01 (ou qualquer outra das 52, desde que tenha como objeto matéria processual e, pelo menos, há uma outra muito célebre ${ }^{427}$ ): ela vai ficar valendo indefinidamente, conquanto nascida provisória e sob condição e, ainda, só será revogável por lei superveniente. As outras medidas provisórias pendentes, que não tratem de processo, podem ser revogadas, seja por outra medida provisória, seja por uma lei .

\section{A MP 2226/01, especificamente, portanto, foi transformada numa verdadeira} super medida provisória, curiosa situação em que o Constituinte Derivado ultrapassou os limites traçados pelo Constituinte Originário, que havia criado as medidas provisórias, dando-lhe mais do que poderia ser dado, o que não é lógico.

Essa aparente singularidade corre o sério risco de ser considerada uma aberração, pois, decorridos mais de nove anos da própria promulgação da EC 32/01, o Congresso Nacional não apreciou nenhuma daquelas medidas provisórias anteriores a ela, incorrendo em injustificável e desarrazoada omissão, passível de censura constitucional.

Colocam-se no limbo normativo essas medidas com força de lei; causa-se prejuízo à democracia; permite-se que o poder não advenha do povo ou de seus representantes, mas

\footnotetext{
${ }^{427}$ Há, pelo menos, mais uma outra polêmica Medida Provisória, anterior à EC 32/01, que no seu bojo traz matéria processual: é a MP n. ${ }^{\circ}$ 2180-35, de 24 de agosto de 2001.Dentre outros assuntos, ela modificou o art. 884 da CLT, ampliando o prazo de embargos à execução pela Fazenda Pública, de cinco (5) para trinta (30) dias e, ainda, acrescentou o $\S 5^{\circ}$ ao art. 884 da CLT, considerando "inexigível o título judicial fundado em lei ou ato normativo declarados inconstitucionais pelo Supremo Tribunal Federal ou em aplicação ou interpretação tidas por incompatíveis com a Constituição Federal". Quanto à ampliação do prazo de embargos, o TST, no julgamento do incidente de inconstitucionalidade RR70/1992-011-04-00.7, encontrável no seu sítio, TRIBUNAL SUPERIOR DO TRABALHO. Disponível em: $<$ http://aplicacao2.tst.jus.br/consultaunificada2/inteiroTeor.do?action=printInteiroTeor\&highlight=true\&nu meroFormatado $=$ RR700066.1992.5.04.0011\&base $=$ acordao\&numProcInt $=117992 \&$ anoProcInt $=2003 \&$ dat aPublicacao=23/09/2005 00:00:00\&query=>. Acesso em: 14 dez. 2010. Rel. Min. Ives Gandra da Silva Martins Filho, declarou-se a inconstitucionalidade do art. $4^{\circ}$ dessa MP 2180-35/01.

No entanto, o Supremo Tribunal Federal, de modo totalmente diverso, não reputou ultrapassados os limites de urgência e relevância, deferindo liminar para que ficassem suspensos todos os processos em que se discutisse a constitucionalidade do art. $1^{\circ} \mathrm{B}$ da Medida Provisória . $^{\circ}$ 2180-35. Neste julgamento não foi enfrentada a questão da possibilidade de ser editada medida provisória, disciplinando processo nem foi abordada a (então nova) disciplina das medidas provisórias, ocorrida com a EC32/01, embora este tema tenha sido mencionado no relatório feito pelo Ministro Cezar Peluso. Inteiro teor do voto desta MC-ADC 11-8 DF, no sítio do SUPREMO TRIBUNAL FEDERAL. Disponível em: $<$ http://redir.stf.jus.br/paginador/paginador.jsp?docTP=AC\&docID=469584>. Acesso em: 14 dez. 2010. Inteiro teor da medida provisória, obtido no sítio BRASIL. Medida provisória n. 2.180-35, de 24 de agosto de 2001. Disponível em: <https://www.planalto.gov.br/ccivil_03/MPV/2180-35.htm>. Acesso em: 14 dez. 2010.
} 
da vontade exclusiva de uma só pessoa, o chefe temporário do Executivo, situação comparável à dos regimes de exceção mais drásticos, inédita na história do Brasil. ${ }^{428}$

À omissão do Congresso Nacional soma-se, infelizmente, a omissão do Supremo Tribunal Federal, pois, os autos da ADI 2527 encontram-se conclusos, com a atual Relatora, Min. Carmen Lúcia, desde 27 de novembro de 2008, há mais de dois anos, portanto, considerado o retorno dos autos do Ministério Público Federal, como pode ser constatado no sítio daquela Corte. ${ }^{429}$

E, retomando-se mais um pouco o moroso julgamento dessa ADI, convém deixar claro que a Procuradoria Geral da República, encaminhou seu parecer em 10 de setembro de 2008, o qual está vazado nos seguintes termos. ${ }^{430}$

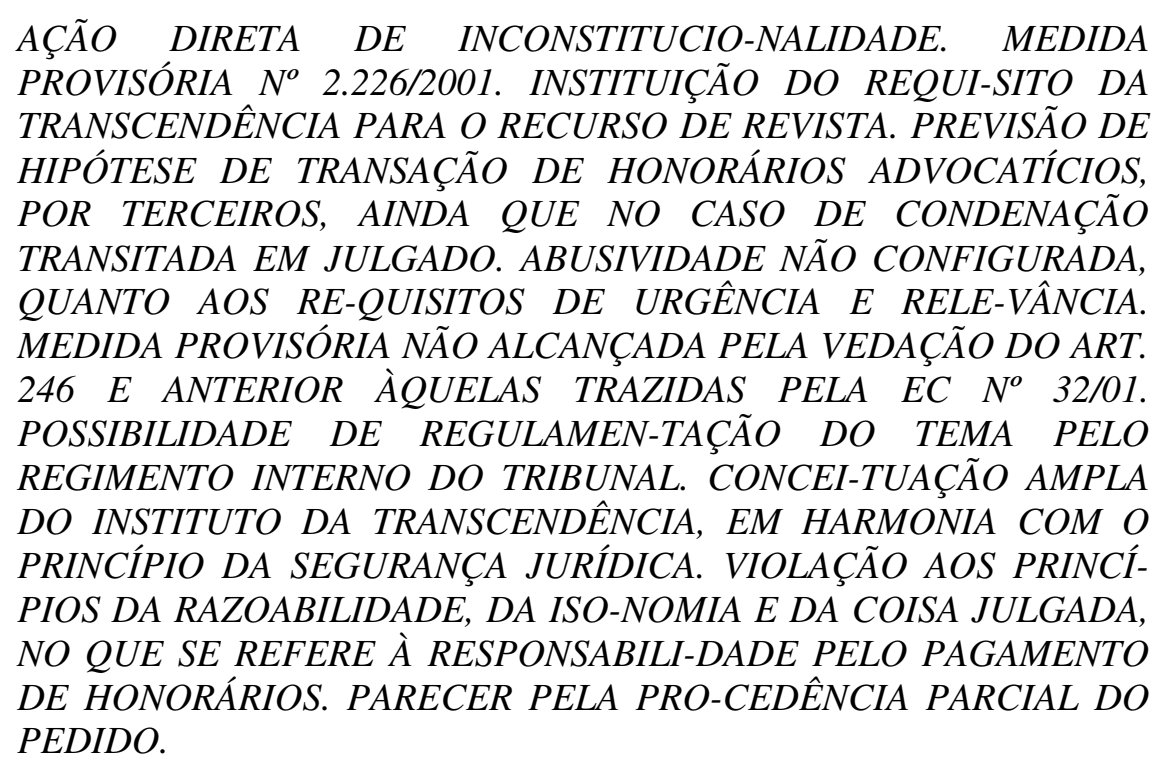

1. Trata-se de ação direta de inconstitucionalidade, com pedido de medida cautelar, ajuizada pelo Conselho Federal da Ordem dos Advogados do Brasil, tendo como objeto a Medida Provisória $n^{\circ} 2.226$, de 4 de setembro de 2001.

2. Eis o teor do texto impugnado:

“Art. $1^{\circ}$ A Consolidação das Leis do Trabalho, aprovada pelo DecretoLei ${ }^{\circ} 5.452$, de $1^{\circ}$ de maio de 1943 , passa a vigorar acrescida do seguinte dispositivo:

\footnotetext{
${ }^{428}$ Vide supra, p. $82-88$

${ }^{429}$ SUPREMO
TRIBUNAL FEDERAL. Disponível em: <http://www.stf.jus.br/portal/processo/verProcessoAndamento.asp?incidente=1970076>. Acesso em: 29 out. 2010.

${ }^{430}$ Obteve-se no Supremo Tribunal Federal, junto ao gabinete da Min. Carmen Lúcia, o inteiro teor do parecer do Ministério Público Federal.
} 
'Art. 896-A. O Tribunal Superior do Trabalho, no recurso de revista, examinará previamente se a causa oferece transcendência com relação aos reflexos gerais de natureza econômica, política, social ou jurídica.' (NR)

Art. $2^{\circ} \mathrm{O}$ Tribunal Superior do Trabalho regulamentará, em seu regimento interno, o processamento da transcendência do recurso de revista, assegurada a apreciação da transcendência em sessão pública, com direito a sustentação oral e fundamentação da decisão.

Art. $3^{\circ} \mathrm{O}$ art. $6^{\circ}$ da Lei $\mathrm{n}^{\circ} 9.469$, de 10 de julho de 1997, passa a vigorar acrescido do seguinte parágrafo, renumerando-se o atual parágrafo único para $\S 1^{\circ}$ :

$\S 2^{\circ} \mathrm{O}$ acordo ou a transação celebrada diretamente pela parte ou por intermédio de procurador para extinguir ou encerrar processo judicial, inclusive nos casos de extensão administrativa de pagamentos postulados em juízo, implicará sempre a responsabilidade de cada uma das partes pelo pagamento dos honorários de seus respectivos advogados, mesmo que tenham sido objeto de condenação transitada em julgado.' (NR)

Art. $4^{\circ}$ Esta Medida Provisória entra em vigor na data de sua publicação."

3. Sustenta o requerente que a norma em apreço ofende o art. 62 da Carta Magna, ante a ausência dos requisitos de urgência e relevância, bem como seu art. 246, por ter regulamentado artigo da Constituição cuja redação fora alterada por meio de emenda promulgada após 1995.

4. Diz, também, ter ocorrido violação ao antigo $\S 3^{\circ}$ do art. 111 da Lei Maior, ao argumento de que o regimento interno do TST não poderia regulamentar o processamento da transcendência do recurso de revista, diante da obrigatoriedade de que a competência do referido tribunal fosse estabelecida em lei.

5. Afirma, ainda, ser o processamento relativo ao recurso de revista matéria de direito processual e que por tal razão, em face do que determinam os arts. 22, I e 24, XI, da Lei Fundamental, não poderia ter sido tratada em sede de medida provisória.

6. Alega, ademais, que os arts. $1^{\circ}$ e $2^{\circ}$ da MP em questão carecem de densidade normativa, uma vez que seriam insuficientes para garantir segurança jurídica aos jurisdicionados, dada a fluidez dos conceitos deles constantes, razão pela qual entende haver vulneração ao Estado de direito e ao princípio da legalidade.

7. Por outro lado, defende ser atentatório ao princípio da razoabilidade o "intento do Estado de não pagar honorários, quando houver acordo em fase de execução, como o desejo de não os pagar, quando reconhece que não tem razão" (fls. 14), além de haver desrespeito ao princípio da isonomia, configurado por um tratamento não uniforme em desfavor do administrado.

8. Finalmente, indica haver ofensa à coisa julgada, no ponto em que se previu hipótese de não pagamento de honorários, a despeito de terem sido objeto de condenação judicial transitada em julgado. 
9. Em suas informações, o Presidente de República ressaltou a excepcionalidade do exame dos requisitos de urgência e relevância pelo Poder Judiciário e defendeu a presença de ambos no caso em apreço. Afastou, da mesma forma, a vedação constante do art. 246 do Texto Constitucional, pela impossibilidade de sua interpretação literal.

10.S alientou haver autorização constitucional para que tribunais disponham acerca da competência de seus órgãos nos respectivos regimentos internos e rechaçou a tese de que a reserva legal existente nos arts. 22 e 24 representaria óbice à edição de medida provisória acerca do tema objeto do ato impugnado.

11. Defendeu que a transcendência prevista no ato impugnado assemelhase a qualquer outro requisito de admissibilidade recursal e que dessa maneira não configuraria qualquer violação a preceito constitucional, especialmente direitos e garantias fundamentais.

12. Observou, no que tange à apontada afronta ao princípio da razoabilidade, ser a restrição à verba honorária adequada e necessária e, por fim, negou qualquer desrespeito à coisa julgada.

13. A medida cautelar foi parcialmente deferida por esse Excelso Pretório, em 16/8/2007, ficando o acórdão assim ementado:

"MEDIDA CAUTELAR EM AÇÃO DIRETA DE INCONSTITUCIONALIDADE. MEDIDA PROVISÓRIA 2.226, DE 04.09.2001. TRIBUNAL SUPERIOR DO TRABALHO. RECURSO DE REVISTA. REQUISITO DE ADMISSIBILIDADE. TRANSCENDÊNCIA. AUSÊNCIA DE PLAUSIBILIDADE JURÍDICA NA ALEGAÇÃO DE OFENSA AOS ARTIGOS $1^{\circ} ; 5^{\circ}$, CAPUT E II; 22, I; 24, XI; 37; 62, CAPUT E $\S 1^{\circ}$, I, B; 111, $\S 3^{\circ}$ E 246. LEI 9.469/97. ACORDO OU TRANSAÇÃO EM PROCESSOS JUDICIAIS EM QUE PRESENTE A FAZENDA PÚBLICA. PREVISÃO DE PAGAMENTO DE HONORÁRIOS, POR CADA UMA DAS PARTES, AOS SEUS RESPECTIVOS ADVOGADOS, AINDA QUE TENHAM SIDO OBJETO DE CONDENAÇÃO TRANSITADA EM JULGADO. RECONHECIMENTO, PELA MAIORIA DO PLENÁRIO, DA APARENTE VIOLAÇÃO AOS PRINCÍPIOS CONSTITUCIONAIS DA ISONOMIA E DA PROTEÇÃO À COISA JULGADA. 1. A medida provisória impugnada foi editada antes da publicação da Emenda Constitucional 32, de 11.09.2001, circunstância que afasta a vedação prevista no art. $62, \S 1^{\circ}, \mathrm{I}, \mathrm{b}$, da Constituição, conforme ressalva expressa contida no art. $2^{\circ}$ da própria EC 32/2001. 2. Esta Suprema Corte somente admite o exame jurisdicional do mérito dos requisitos de relevância e urgência na edição de medida provisória em casos excepcionalíssimos, em que a ausência desses pressupostos seja evidente. No presente caso, a sobrecarga causada pelos inúmeros recursos repetitivos em tramitação no TST e a imperiosa necessidade de uma célere e qualificada prestação jurisdicional aguardada por milhares de trabalhadores parecem afastar a plausibilidade da alegação de ofensa ao art. 62 da Constituição. 3. Diversamente do que sucede com outros Tribunais, o órgão de cúpula da Justiça do Trabalho não tem sua competência detalhadamente fixada pela norma constitucional. A definição dos respectivos contornos e dimensão é remetida à lei, na forma do art. $111, \S 3^{\circ}$, da Constituição Federal. As normas em questão, portanto, não alteram a competência constitucional- 
mente fixada para o Tribunal Superior do Trabalho. 4. Da mesma forma, parece não incidir, nesse exame inicial, a vedação imposta pelo art. 246 da Constituição, pois, as alterações introduzidas no art. 111 da Carta Magna pela EC 24/99 trataram, única e exclusivamente, sobre o tema da representação classista na Justiça do Trabalho. 5. A introdução, no art. $6^{\circ}$ da Lei $n^{\circ}$ 9.469/97, de dispositivo que afasta, no caso de transação ou acordo, a possibilidade do pagamento dos honorários devidos ao advogado da parte contrária, ainda que fruto de condenação transitada em julgado, choca-se, aparentemente, com a garantia insculpida no art. $5^{\circ}$, XXXVI, da Constituição, por desconsiderar a coisa julgada, além de afrontar a garantia de isonomia da parte obrigada a negociar despida de uma parcela significativa de seu poder de barganha, correspondente à verba honorária. 6 . Pedido de medida liminar parcialmente deferido."

16. Ouvida, a Advocacia Geral da União pronunciou-se pela improcedência do pedido, corroborando os fundamentos deduzidos nas informações prestadas pelo requerido.

17. A respeito da presença de relevância e urgência, é preciso reconhecer a possibilidade de o Poder Judiciário exercer o controle jurisdicional de tais requisitos, a fim de evitar eventuais abusos na edição dessa excepcional espécie normativa.

18. Com efeito, configuram-se os pressupostos em questão como elementos inerentes à própria regra constitucional que confere competência ao Chefe do Poder Executivo para editar as medidas provisórias, o que autoriza sua submissão ao controle jurisdicional. A respeito, ponderou o Ministro Celso de Mello no voto proferido no julgamento do pedido de liminar formulado nos autos da $\mathrm{ADC}^{\circ} 11$ :

“(...)Os pressupostos em questão - urgência da prestação legislativa $\underline{\mathbf{e}}$ relevância da matéria a ser disciplinada - configuram elementos que compõem a própria estrutura constitucional da regra que habilita o Chefe do Executivo, excepcionalmente, a editar medidas provisórias.

Tais pressupostos, precisamente porque são requisitos de índole constitucional, expõem-se, enquanto categorias de natureza jurídica, à possibilidade de controle jurisdicional.

É que a carga de discricionariedade política, subjacente à formulação inicial, pelo Chefe do Executivo, do juízo concernente aos requisitos da urgência e da relevância, não pode legitimar o exercício abusivo da prerrogativa extraordinária de legislar.

Vê-se, pois, que a relevância e a urgência - que se revelam noções redutíveis à categoria de conceitos relativamente indeterminados - qualificam-se como pressupostos constitucionais legitimadores da edição das medidas provisórias. Constituem requisitos condicionantes do exercício desse poder extraordinário de legislar que a Carta Política outorgou ao Presidente da República.

Tratando-se de requisitos de índole constitucional, cabe, ao Supremo Tribunal Federal, em cada caso ocorrente, analisar a configuração desses pressupostos, cuja existência se revela essencial ao processo de 
legitimação do exercício, pelo Presidente da República, do seu poder de editar medidas provisórias.

(...) “ (ADC 11-MC, Ministro Cezar Peluso, DJ de 29/6/2007, p. 20).

19. No caso dos autos, não há como se concluir pelo abuso por parte do Chefe do Poder Executivo, porquanto bem delineadas, nas informações prestadas pelo requerido, as razões de urgência e relevância que levaram à edição da Medida Provisória. Conforme lembrado às fls. 54, norma de igual teor foi submetida ao Congresso Nacional por meio de projeto de lei que - em razão da situação de colapso enfrentado pelo TST - por três vezes contou com pedido de urgência constitucional, sem contudo ser examinada por aquela Casa. Assim, ainda que se possa admitir críticas quanto ao grau de efetividade levado a efeito por meio da medida adotada, não há com qualificá-la de abusiva.

20. Igualmente descabida é a alegação de ofensa ao disposto no art. 246 da Constituição da República. Afinal, a EC no 24/99, apesar de ter promovido modificações no art. 111 (novamente modificado pela $\mathrm{EC} \mathrm{n}^{\circ}$ $45 / 2004$, posterior ao presente ajuizamento) não trouxe qualquer inovação atinente à competência do Tribunal Superior do Trabalho. Não há espaço para a análise literal feita pelo requerente acerca do comando contido no citado art. 246.

21. A esse respeito, tem prevalecido junto à Corte Suprema o entendimento bem sintetizado pela Ministra ELLEN GRACIE, em voto proferido na ADI-MC 3.090 (Ministro GILMAR MENDES, DJ de 26/10/2007, p. 27) segundo o qual "apenas se mostra razoável $e$ sistemática uma interpretação restritiva do art. 246 da Constituição Federal, que proíba a edição de medida provisória, unicamente, para o disciplinamento infraconstitucional das alterações efetivamente promovidas pelo legislador constituinte derivado, sendo, portanto, inadequado entender vedada tal regulamentação, do momento da promulgação da Emenda em diante, de todo e qualquer quesito do campo temático-normativo abordado no dispositivo constitucional reformado".

22. Do mesmo modo, é de se reconhecer que não havia, ao tempo da edição da MP em questão, limitação quanto ao uso deste instrumento no campo do direito processual, dado que a restrição trazida pela $\mathrm{EC} \mathrm{n}^{\circ}$ 32/2001 (art. 62, I, "b") veio acompanhada de ressalva expressa quanto às medidas provisórias até então editadas, como é o caso da MP 2.226, de 4 de setembro de 2001.

23. Quanto à alegação de que somente a lei em sentido estrito poderia dispor acerca da competência do TST, mais uma vez o requerente apela para um rigor literal, ao interpretar isoladamente o antigo $\S 3^{\circ}$ do art. 111. Como já destacado nos autos, a própria Constituição, em seu art. 96, I, "a", confere aos tribunais a prerrogativa de dispor sobre a competência e o funcionamento dos respectivos órgãos jurisdicionais, por meio de seus regimentos internos.

24. No que concerne aos suscitados vícios de ordem material, não merece acolhida a tese de insuficiência normativa tendente a provocar insegurança jurídica. 
25. A prevalecer este entendimento, estariam os tribunais superiores impedidos de aplicar outros requisitos de admissibilidade recursais igualmente subjetivos tais como o prequestionamento (como bem lembrado nas informações oriundas da Presidência da República), ou - no caso específico do Supremo Tribunal Federal - do próprio instituto da repercussão geral $\left(\mathrm{CF}\right.$, art. $\left.102, \S 3^{\circ}\right)$, cuja exegese afigura-se tão ampla quanto à da transcendência, apesar de estabelecidos certos balizamentos pela Lei $\mathrm{n}^{\circ} 11.418$, de 19 de novembro de 2006.

26. O mesmo raciocínio pode ser aplicado no que se refere ao parâmetro de controle da argüição de descumprimento de preceito fundamental - até hoje sem uma delimitação completa de seu alcance - , ou à construção jurisprudencial cristalizada por meio da Súmula $\mathrm{n}^{\circ} 288$ do STF, segundo a qual "nega-se provimento a agravo para subida de recurso extraordinário, quando faltar no traslado o despacho agravado, a decisão recorrida, a petição de recurso extraordinário ou qualquer peça essencial à compreensão da controvérsia" (grifado) .

27. Esta flexibilidade concedida ao julgador, por meio de conceitos passíveis de uma interpretação ampla, em verdade, está a prestigiar a segurança jurídica, na medida em que evita o engessamento do Judiciário e, por conseguinte, a prolação de decisões cartesianas, diante da complexidade e da peculiaridade das controvérsias jurídicas que lhe são apresentadas.

28. Por outro lado, no que tange à impugnação deduzida contra $o$ art. $3^{\circ}$ da MP 2.226/2001, assiste razão ao requerente. Na esteira das considerações tecidas pelo Ministro MAURÍCIO CORRÊA, sendo os honorários de sucumbência devidos aos advogados da parte vencedora, não há fundamento em se permitir que tal direito seja transacionado por terceiros (no caso as partes).

29. Ademais, conforme destacado pela relatora, a retirada préestabelecida da verba honorária de uma das partes, configura ofensa ao princípio da isonomia, uma vez que não se verifica qualquer justificativa plausível para tal desequilíbrio.

30. Cumpre ressaltar, finalmente, que é, de fato, latente a violação ao princípio da coisa julgada, na medida em que se está a permitir a alteração de condenações já transitadas em julgado.

Ante o exposto, o parecer é pela procedência parcial do pedido, para que a declaração de inconstitucionalidade seja restrita ao art. $3^{\circ}$ da Medida Provisória $\mathrm{n}^{\circ}$ 2.226/2001.

Brasília, 14 de agosto de 2008.

ANTONIO FERNANDO BARROS E SILVA DE SOUZA

PROCURADOR-GERAL DA REPÚBLICA 
Como se vê, especificamente no item 22 do Parecer, o Ministério Público Federal chega a dizer, de forma peremptória, "que não havia, ao tempo da edição da MP em questão, limitação quanto ao uso deste instrumento no campo do direito processual, dado que a restrição trazida pela EC n 32/2001 (art. 62, I, "b") veio acompanhada de ressalva expressa quanto às medidas provisórias até então editadas, como é o caso da MP 2.226, de 4 de setembro de 2001 ”.

Incompreensivelmente, porém, o Parquet Federal, que atua junto à Suprema Corte, está em aberto e flagrante contraste com jurisprudência ali firmada no julgamento da ADI 1910-MC, desde 1999, cujos fundamentos determinantes (ratio decidendi) hão de ser aplicados porque vinculantes, sistemática implantada desde a EC 03/93 (reiterada e ampliada pela EC45/04) e, ainda, tese consagrada pelo Plenário do STF nas Reclamações 1987 e 2263.

\subsection{A Difícil Regulamentação}

Conforme visto no capítulo 2, item 2.4, depois que o Supremo Tribunal Federal completou o julgamento da medida liminar da ADI 2527, aparentemente não havia mais motivo para que o Tribunal Superior do Trabalho deixasse de dar cumprimento ao art. $2^{\circ}$ da Medida Provisória 2226/01, daí por que houve uma primeira tentativa de se regulamentar a transcendência, à época em que presidia o TST o Ministro Rider Nogueira de Brito. A comissão dissolveu-se sem apresentar um resultado, até que, em 13 de outubro de 2009, já sob a presidência do Ministro Milton de Moura França, foi editada a Resolução Administrativa $\mathrm{n}^{\circ}$ 1360/2009, cujo art. $1^{\circ}$ assim instituiu:

Art. $1^{\circ}$ Fica constituída Comissão Temporária, integrada pelos Exmos. Srs. Ministros João Oreste Dalazen (Presidente), Ives Gandra Martins Filho, Brito Pereira, Maria Cristina Irigoyen Peduzzi e Lélio Bentes Corrêa, destinada a estudar a viabilidade da regulamentação interna do disposto no art. 896-A da CLT, que instituiu o critério de transcendência para o exame prévio no Recurso de Revista. ${ }^{431}$

\footnotetext{
${ }^{431}$ TRIBUNAL SUPERIOR DO TRABALHO. Resolução Administrativa n. 1360, de 13 de outubro de 2009. Disponível em: <http://www.tst.jus.br/DGCJ/IndiceResolucoes/ResAdm/1360.pdf>. Acesso em: 17 out. 2010.
} 
Os trabalhos da Comissão encerraram-se em 30.06.2010, tendo o Min. João Oreste Dalazen ${ }^{432}$, em nome dela, encaminhado ao Presidente do Tribunal Superior do Trabalho o ofício JODGVP n ${ }^{\circ} 55 / 2010$, apresentando as seguintes justificativas e conclusões:

Senhor Ministro Presidente,

Honra-me comunicar a V. Exa. que a Comissão instituída mediante a Resolução Administrativa $n^{\circ} 1360 / 2009$, após sucessivas reuniões e estudos concluiu:

1.por maioria, pela inviabilidade técnica de regulamentar o critério da transcendência no âmbito do Tribunal Superior do Trabalho, para adoção no recurso de revista, em virtude das razões expostas no voto em anexo do ora subscritor e Presidente da Comissão; vencido o Exmo. Ministro Ives Gandra da Silva Martins Filho;

2. igualmente por maioria, vencido o Exmo. Ministro Ives Gandra da Silva Martins Filho, a Comissão decidiu aprovar o anteprojeto de lei alternativo em anexo.

O aludido anteprojeto, entre várias outras propostas visando a inibir novos recursos no TST, incorpora as seguintes:

a) obriga os Regionais a uniformizar a respectiva jurisprudência interna e a adotar o novo incidente de resolução de demandas repetitivas previsto no projeto de CPC, ora em exame no Senado Federal, em que caberá reclamacão para o TRT competente, caso não observada a tese adotada pela decisão proferida no incidente;

b) retira definitivamente do TST o papel de uniformização da jurisprudência interna dos Regionais ao declarar que, após o julgamento do incidente referido no item "a", unicamente a súmula regional ou a tese jurídica prevalecendo no Tribunal Regional do Trabalho e não conflitante com Súmula ou Orientação Jurisprudencial do TST serve como paradigma para viabilizar o conhecimento do RR, por divergência;

c) determina a aplicação ao recurso de revista, no que couberem, das normas previstas no projeto de novo Código Processo Civil que passarão a reger o julgamento dos recursos extraordinário e especial repetitivos, $o$ que ensejará ao TST: c1) selecionar um ou mais recursos representativos da controvérsia; c2) ordenar a suspensão dos processos em primeiro e segundo graus sobre a questão jurídica controvertida, até o julgamento da tese no TST, sob pena de anulação da decisão e acolhimento da reclamação, tudo como dispuser o Regimento Interno do TST, que poderá disciplinar a questão em face dos temas múltiplos versados no RR;

\footnotetext{
${ }^{432}$ Sua Excelência o Ministro João Oreste Dalazen, Vice Presidente do Tribunal Superior do Trabalho e Presidente da Comissão Temporária encarregada da análise da transcendência, autorizou o uso e a divulgação dos documentos transcritos neste trabalho acadêmico. Deixa-se claro, todavia, que as deliberações e o anteprojeto de lei apresentados pela Comissão ainda não foram submetidos à apreciação do Plenário daquela Corte, o que, segundo informações, só ocorrerá sob a nova gestão que se iniciará em março de 2011.
} 
d) adiciona outras exigências formais para o conhecimento do RR, tal como a demonstração analítica de cada dispositivo de lei cuja violação seja apontada e a indicação da ata de audiência que configure o eventual mandato tácito;

e) majora substancialmente a multa para embargos de declaração protelatórios e agravo manifestamente infundado;

f) legitima a competência do Tribunal Superior do Trabalho para processar e julgar reclamação para a preservação de sua competência e a autoridade de suas decisões;

g) valoriza o papel de uniformizador de jurisprudência do TST e de predominância da substância sobre a forma ao prever que, quando o recurso tempestivo for inadmissível por defeito formal que não se repute grave, o Tribunal Superior do Trabalho poderá desconsiderar o vício e julgar o mérito de casos repetitivos ou sempre que a decisão da questão de mérito contribua para o aperfeiçoamento do sistema jurídico.

Finalmente, Senhor Presidente, a Comissão sugere a V. Exa. que, após consulta aos demais Ministros da Corte, haja encaminhamento do anteprojeto ao Poder Executivo com vistas à encaminhá-lo ao Congresso Nacional.

A tese vencedora na Comissão está sistematizada no voto de seu Presidente, Ministro João Oreste Dalazen, cujo inédito inteiro teor é o seguinte:

\section{REGULAMENTAÇÃO DA TRANSCENDËNCIA NO TST}

\section{TRANSCENDËNCIA APENAS NO AGRAVO DE INSTRUMENTO}

Absolutamente inviável disciplinar apenas para o agravo de instrumento porque se exigiria da parte fundamentar, em preliminar do RR, a transcendência. Logo, SE ADMITIDO $\mathbf{O} \underline{\mathbf{R R}}$ pela Presidência do Regional, por divergência ou violação, necessariamente a Turma ou o Relator no TST haveria de emitir juízo de delibação sobre a transcendência ou não da matéria versada no RR.

\section{TRANSCENDËNCIA NO RR}

Afiguram-se-me inquestionáveis os bons e louváveis propósitos em que se inspira o propósito de regulamentar a transcendência para o RR no TST, sobretudo na busca de maior celeridade e racionalidade no julgamento desse recurso de natureza extraordinária.

Por isso, nunca me posicionei refratário a que envidemos esforços em prol do disciplinamento normativo da transcendência.

Concluí, todavia, após profunda e detida reflexão sobre os desdobramentos e implicações daí derivantes, que, na prática, sobretudo ante as especificidades do processo trabalhista, a disciplina da 
transcendência para o RR, além de inconveniente, apresenta-se inexequíivel, pois remarcada de obstáculos técnicos intransponíveis, de índole diversa.

\subsection{NATUREZA JURÍDICA}

Uma primeira e delicada questão técnica repousa na natureza jurídica do instituto e nas implicações processuais dela decorrentes.

Penso que se cuida de um juízo de delibação sobre a natureza da causa, mais precisamente um mecanismo de seleção dos processos "não transcendentes" para efeito de o Tribunal abster-se de julgamento no mérito. Sob esse prisma, nenhuma questão subseqüente adviria da declaração de intranscendência do RR.

O problema que inevitavelmente emerge resulta da hipótese inversa: declarada a transcendência, o recurso de revista está automaticamente admitido? O bom senso pareceria indicar que sim.

A Medida Provisória 2226/01 que incorporou a transcendência à CLT, no entanto, como se sabe, não revogou os pressupostos extrínsecos e intrínsecos do RR.

Forçoso convir, assim, que o critério de transcendência deveria coexistir com a exigência de atendimento aos pressupostos extrínsecos e intrínsecos do RR.

Resultado: declarada a transcendência, o RR poderia não ser conhecido, em continuidade do julgamento, pela ausência de pressuposto extrínseco ou intrínseco

Já aí se descortinaria um desfecho manifestamente ilógico... Afinal, indaga-se: faz sentido uma questão declarada transcendente não ser, a seguir, apreciada pelo TST?

Parece inarredável concluir-se, todavia, que, em face do teor sucinto da Medida Provisória 2226/01, declarada a transcendência, o recurso de revista NÃO ESTÁ automaticamente admitido, até porque, do contrário, também haveria sério problema: ampliar-se-ia contra legem o âmbito de conhecimento do RR em procedimento sumaríssimo...

Se assim é, esse panorama sinalizaria que o exame dos pressupostos extrínsecos e intrínsecos deveria preceder ao juízo de delibação sobre a transcendência.

De outro lado, a necessidade de exame também dos pressupostos extrínsecos e intrínsecos de admissibilidade, ao menos nos casos em que seja declarada a transcendência, por si só denota que o juízo de delibação sobre a transcendência pode conduzir a resultados ilógicos e insatisfatórios (não se conhecer de um recurso declarado transcendente por ausência de pressuposto de admissibilidade), além de não oferecer proveito algum para a dinamização dos julgamentos.

A aparente solução para se afastar a apontada falta de lógica seria, em tese, a inversão na ordem de apreciação das questões processuais em 
apreço: primeiro, o exame dos pressupostos extrínsecos e intrínsecos de admissibilidade do RR; depois, o juízo de delibação sobre a transcendência.

Diga-se de passagem, esta última é a diretriz por que se pauta o STF na apreciação da questão análoga da repercussão geral, consoante se extrai do art. 323 do Regimento Interno do STF:

"Art. 323. Quando não for o caso de inadmissibilidade do recurso por outra razão, o(a) Relator (a) submeterá, por meio eletrônico, aos demais ministros, cópia de manifestação sobre a existência, ou não, de repercussão geral".

No tocante ao RR, contudo, a acenada diretriz de o exame dos pressupostos extrínsecos e intrínsecos de admissibilidade do RR preceder ao exame da transcendência, por óbvio também não se revelaria uma solução adequada porque meramente aumentaria o trabalho do Relator ou da Turma.

Importa dizer que, também sob esse ângulo, a norma sobre transcendência traduziria, em última análise, uma das "Leis de Murphy": solução que cria novos problemas.

Nesta perspectiva, penso que o ideal é que a Medida Provisória que incorporou a transcendência à CLT houvesse erigido a transcendência como critério único de seleção de causas para julgamento.

\subsection{REGULAMENTAÇÃO: CONTRAPRODUCENTE}

Outras razões robusteceram-me a convicção de que regulamentar a transcendência para o RR certamente irá revelar-se contraproducente, gerando mais problemas que solução.

Para tanto concorrem, sobretudo, a multiplicidade de temas normalmente versados no $R R$ e a natural e quase intransponível dificuldade conceitual do que seja transcendência com relação aos reflexos gerais de natureza econômica, política, social ou jurídica.

Trata-se de questões imbricadas, a meu juízo.

Obviamente a implantação do sistema exigiria da parte demonstrar a transcendência em relação a cada tema e, por conseguinte, obviamente também exigiria da Turma do TST, em contrapartida, um pronunciamento específico sobre a transcendência em relação a cada tema, para se dar cumprimento ao dever de fundamentar a decisão.

Aqui surge um dos grandes problemas da regulamentação e, notadamente, da aplicação do instituto: é impossível definir, de forma exaustiva, o que se considera cada uma dessas espécies de transcendência. A própria definição proposta pelo Ministro Ives não pôde deixar de expor, a propósito, alguns "indicadores, entre outros". Ou seja, não deixaria de ser, neste passo, norma jurídica praticamente em aberto. 
Nada conceituar, por outro lado, implicaria abrir um largo campo à indesejável discricionariedade e à falta de uniformidade, paradoxalmente de um órgão cuja missão precípua é uniformizar.

Certo, no STF, em relação à situação análoga da repercussão geral, sabemos que a própria lei não ministra critério para precisar o que seja repercussão geral sob o ponto de vista econômico, jurídico, social ou político. Há norma jurídica em branco dispondo sobre essa questão.

A despeito disso, o sistema tem produzido resultados proveitosos no STF porque lá, não se pode olvidar, há diferenças fundamentais em relação ao TST:

a) quase sempre tema único;

b) deliberação sobre existência, ou não, de repercussão tomada quase sempre em plenário, ainda que virtual;

c) irrecorribilidade da decisão.

No caso do TST, em que o panorama é exatamente o oposto, é fácil antever as gigantescas dificuldades que se apresentam para o Relator ou para a Turma, ou para o próprio Tribunal como um todo, advindas da implantação da transcendência.

Primeiro, a dificuldade imensa de o Relator fundamentar a intranscendência. Sim, poderia fazê-lo de forma sucinta, mas necessariamente com os olhos fitos no caso concreto, do tema específico abordado no RR, sob pena de nulidade da decisão.

Tome-se o caso da transcendência econômica: o valor da causa na JT, tomado por estimativa, é quase sempre irreal e retrata o conjunto dos múltiplos pedidos em geral formulados pelo Reclamante.

Questiona-se, então: como considerar que um pedido em que se insiste no RR ostente transcendência econômica em face do valor da causa?

Também o valor da condenação, como sabemos, é provisoriamente arbitrado para um elenco de condenações em pecúnia e muitas vezes irreal. Como, então, fiar-se no valor arbitrado para uma condenação em bloco e daí extrair transcendência econômica relativamente a uma das pretensões jurídicas de direito material acolhidas pelo Regional e impugnadas no RR?

Nota-se, portanto, que é extremamente difícil, senão impossível, em semelhante quadro, divisar-se um critério mínimo seguro sobre o que seja transcendência econômica para nortear o Relator ou a Turma.

Resultado: subjetivismo inafastável de critérios entre oito órgãos fracionários do TST.

Diga-se o mesmo da transcendência social e da transcendência jurídica.

A segunda dificuldade ou inconveniência repousa em se abrir o leque do recurso de embargos para a SDI-1, com mais uma hipótese de divergência entre Turmas para viabilizá-lo: agora sobre o juízo de 
delibação acerca da transcendência, NEGADA OU RECONHECIDA!!!!

Está claro que, como é natural, máxime em virtude da inviabilidade de erigir-se critério rígido de transcendência, logo as Turmas estariam rendendo ensejo a um vasto campo de cabimento de embargos para a SDI por discrepância no juízo de delibação sobre transcendência em situações absolutamente específicas ou pretensamente específicas, envolvendo a mesma empresa e o mesmo tema.

Mais ainda: em muitas situações, até mesmo para retardar, a parte poderá interpor embargos por suposta divergência, quer da decisão que não reconheceu transcendência, quer da decisão que reconheceu transcendência.

De fato, pode configurar-se perfeitamente esta situação complexa e até insólita no caso de a Turma admitir a transcendência em relação a um dos temas versados no RR e negá-la em relação aos demais: recurso de embargos por divergência quanto ao juízo de delibação sobre transcendência, de ambas as partes.

Por outro lado, se a SDI prover os embargos para reconhecer a transcendência, não seria viável julgar imediatamente "o mérito do recurso", como propõe o projeto do Min Ives (art. $2^{\circ}$. fine).

Ora, se a Turma cingiu-se a emitir juízo de delibação sobre a transcendência, obviamente não há como a parte impugnar o que não se decidiu e, em particular, apontar divergência sobre o que não se decidiu acerca dos pressupostos extrínsecos e intrínsecos de admissibilidade do RR. Logo, inconcebível a SDI prosseguir no julgamento, de pronto, após afastar a declaração turmária de intranscendência. Em semelhante circunstância, portanto, necessariamente a SDI haveria de determinar o retorno à Turma para prosseguimento.

Percebe-se, assim, que são numerosos os desdobramentos práticos reveladores de que a transcendência, em relação ao TST, pode constituirse, em derradeira análise, num fator também de maior retardamento na outorga da prestação jurisdicional trabalhista.

\subsection{ESVAZIAMENTO DA FUNÇÃO UNIFORMIZADORA DO TST}

O terceiro e relevante motivo que milita contra a adoção da transcendência no TST é de ordem político-institucional: implicaria um esvaziamento, por renúncia tácita, às duas missões básicas da Corte em sede de recurso de revista: uniformização de jurisprudência e primado da lei federal violada na esfera de sua competência.

Com efeito. Temas sobre os quais não se reconhecesse transcendência, mesmo que caracterizada divergência jurisprudencial idônea e específica no RR, conduziriam a Corte a não uniformizar ou a não restabelecer o primado da lei violada.

Tomemos alguns exemplos concretos, a título de ilustração do que se vem de afirmar: 
a) o RR 2230/2004-122-15-00.9, em que se discutia a incidência de contribuição previdenciária sobre aviso prévio indenizado, foi conhecido por divergência jurisprudencial e provido pela $1^{\text {a }}$ Turma; se adotada a transcendência, não haveria como capitular o tema nos conceitos propostos de transcendência econômica, jurídica, política ou social; a matéria, assim, escaparia à atuação uniformizadora do TST, a despeito da disceptação jurisprudencial presente;

b) o RR 1001/2006-108-03-00.8, em que se discutia se entidade de fiscalização profissional (CRM) beneficia-se dos privilégios processuais do Decreto-lei $\mathrm{n}^{\mathrm{o}} 779 / 69$, a $4^{\mathrm{a}}$ Turma conheceu, por violação, e deu-lhe provimento para afastar deserção de recurso ordinário; se adotada a transcendência, também não haveria como capitular o tema nos conceitos propostos de transcendência econômica, jurídica, política ou social; o TST, assim, abster-se-ia de proclamar a autoridade da lei federal regente da matéria;

c) idem num RR em que se pretenda discutir, por divergência, reflexos do d.s.r. em adicional de periculosidade;

d) idem num RR cujo objeto seja afronta à coisa julgada material perpetrada na execução trabalhista, seja em detrimento do exeqüente, seja em detrimento do executado.

\section{CONCLUSÃO}

Eis as razões pelas quais concluo pela inviabilidade técnica e inconveniência política de regulamentação da transcendência no âmbito do Tribunal Superior do Trabalho.

A tese vencida foi enunciada pelo Min. Ives Gandra da Silva Martins Filho, cujos termos são os seguintes: ${ }^{433}$

\section{JUSTIFICATIVA DE VOTO VENCIDO}

\section{1) NECESSIDADE, CONVENIÊNCIA E VIABILIDADE DA ADOÇÃO DO CRITÉRIO DE TRANSCENDÊNCIA PARA O RECURSO DE REVISTA NO ÂMBITO DO TST - INCONVENIÊNCIA DE APLICAÇÃO SUBSIDIÁRIA DA LEI DOS RECURSOS REPETITIVOS AO RECURSO DE REVISTA}

O art. 896-A da CLT, introduzido pela Medida Provisória 2.226/01, passou a integrar definitivamente nosso ordenamento jurídicoprocessual trabalhista, após a promulgação da Emenda Constitucional $32 / 01$, nos termos do art. $2^{\circ}$ da emenda, que apenas admite sua revogação por deliberação definitiva do Congresso Nacional rejeitando-a, já que não precisa ser reeditada, nem pode ser revogada por medida provisória expressa em sentido contrário, uma vez que, por se tratar de matéria processual, não comporta revogação por outra medida provisória, a teor

\footnotetext{
${ }^{433}$ Sua Excelência o Ministro Ives Gandra da Silva Martins Filho autorizou o uso e a divulgação de seu voto vencido neste trabalho acadêmico, conquanto, tal como ocorre com o voto prevalente, ainda não tenham sido analisados pelo Plenário do Tribunal Superior do Trabalho
} 
do art. $62, \S 1^{\circ}, \mathrm{I}, \mathrm{b}$.

O referido dispositivo consolidado foi reputado constitucional pelo Supremo Tribunal Federal, quer quanto à sua introdução no ordenamento jurídico brasileiro pela via da medida provisória, quer sob o prisma de sua conformidade material e formal com a Carta Política de 1988 (cfr. MCADI-2.527-9-DF, Rel. Min. ELLEN GRACIE, publicado no DJ de 23/11/07).

Nesses termos, tendo o art. $2^{\mathbf{0}}$ da MP 2.226/01 cometido ao TST o poder-dever de regulamentar o art. 896-A da CLT, e sendo este preceito vigente e constitucional de nosso ordenamento jurídico, peca esta Corte por omissão regulamentar.

A opção política pela adoção do critério de transcendência competia ao Legislador e foi feita, e o controle de constitucionalidade cabia ao Supremo Tribunal Federal e foi realizado. Não havendo inconstitucionalidade e estando vigente a norma consolidada, não cabe ao TST deixar de regulamentar a norma legal.

Rejeitar a inovação por ter sido veiculada mediante medida provisória é olvidar que a própria CLT foi instituída mediante decreto-lei, ato também oriundo de atividade legiferante do Poder Executivo, e nem por isso deixa de ter seu mérito, relevância e caráter vinculante para o Poder Judiciário, como norma a ser respeitada e implementada.

A opção da maioria da Comissão Temporária pela negativa de regulamentação e de envio de projeto de lei alterando normas relativas aos pressupostos de admissibilidade do recurso de revista, propondo a aplicação subsidiária da Lei dos Recursos Repetitivos própria do recurso especial que tramita no STJ, a par de ser ilegal, trilha caminho mais complexo e ineficaz do que a pecha de inconveniente e inexeqüível que atribui ao critério de transcendência.

Com efeito, uma das características do Processo do Trabalho é a da generalização da cumulação objetiva de pedidos nas reclamatórias trabalhistas, o que faz com que um processo não seja um, mas vários, conforme o número de pedidos diferentes. E cada pedido deve ser analisado segundo sua normativa própria, formando-se jurisprudência específica.

Nesse sentido, se cada recurso trabalhista alberga várias matérias diferentes, é praticamente impossível utilizar subsidiariamente sistemática de racionalização judicial focada em recursos de tema único, que podem ser julgados por lote e voto-padrão, além de sobrestados até que seja fixado o entendimento do Tribunal quanto à matéria e aplicado pelas Cortes inferiores, com juízo de retratação em caso de decisão proferida em sentido contrário à jurisprudência pacificada.

Imagine-se, por exemplo, recurso de revista com 10 temas, encontradiço no TST, em que haja apenas 5 temas com jurisprudência pacificada. Ficará ele sobrestado, até formalizado o juízo de retratação, prosseguindo pelos temas remanescentes. $\mathrm{E}$ mais: A 
cada fase, pararia o processo, aguardando a pacificação de algum tema, com notório comprometimento do princípio da celeridade processual (CF, art. $5^{\circ}$, LXXVIII).

Já com o critério de transcendência, concebido justamente tendo em conta as características do Processo do Trabalho, o recurso de revista seria analisado no seu todo, para ver se a causa justificaria uma nova revisão, em $3^{a}$ instância, pela sua transcendência jurídica, política, econômica ou social.

Da mesma forma que, na $1^{\mathrm{a}}$ instância, a vocação conciliadora própria da Justiça do Trabalho, consegue solucionar boa parte das causas - repita-se, com muitos pedidos simultâneos - pela obtenção de acordo entre as partes que englobe a ação como um todo, assim também, na $3^{\mathrm{a}}$ instância da Justiça do Trabalho, a ação seria apreciada globalmente, para verificar se, no todo (sob o prisma econômico e social), em algum de seus temas - e só nesse (sob o prisma jurídico e político), justificaria um reexame pelo TST.

O TST, como Tribunal Superior, deve julgar teses e não casos. Sua missão constitucional é apenas - e não é pouco - dar o conteúdo normativo das leis federais trabalhistas, uniformizando a jurisprudência dos Tribunais Regionais na interpretação do ordenamento jurídico-trabalhista pátrio. Pretender continuar apreciando pormenorizadamente todas as causas que chegam à Corte (ou sumariamente, pela mera remissão ou reprodução dos fundamentos da decisão recorrida), mormente com o volume avassalador e crescente de recursos que chegam diariamente - mais de mil -, é persistir em paradigma exaurido, contrariando o esforço moderno de racionalização judicial.

O novo paradigma da transcendência permitirá simplificar a forma de apreciação dos recursos de revista e agravos de instrumento, como fator de seleção das causas que justifiquem uma $3^{\text {a }}$ instância de revisão do processo, para fixação de teses, o que terá como corolário a obtenção de tempo e condições de exame detido e profundo, com debate amplo e tranqüilo das questões efetivamente relevantes de Direito e Processo do Trabalho.

Ademais, não se vislumbra qualquer inexequibilidade da adoção do critério de transcendência, e muito menos limitada, inicialmente, aos agravos de instrumento, que representam $\mathbf{7 5 \%}$ dos processos que tramitam no TST. As próprias resoluções desta Corte, que foram delegando paulatinamente ao Presidente do TST o exame de agravos de instrumento e recurso de revista, mostram como é perfeitamente possível a regulamentação, já que na referida delegação, a norma celetista, que afeta às Turmas o exame dos recursos de revista e dos agravos de instrumento neles interpostos, apresenta menor margem de flexibilidade. E, no entanto, as resoluções foram adotadas.

Assim, não há como deixar de regulamentar o art. 896-A da CLT, sob pena de desrespeito a nosso ordenamento jurídico e de precarização da prestação jurisdicional no âmbito do TST, com o crescimento constante da demanda processual. 


\section{2) PROPOSTA DE REGULAMENTAÇÃO DO ART. 896-A DA CLT, LIMITADA AO AGRAVO DE INSTRUMENTO EM RECURSO DE REVISTA}

Art. $1^{\circ}$ - Antes de apreciar o mérito de agravo de instrumento que vise a destrancar recurso de revista, caberá ao Relator verificar se o recurso trancado oferece transcendência com relação aos reflexos gerais de natureza econômica, política, social ou jurídica.

$\S 1^{\circ}$ - São indicadores, entre outros, de transcendência:

I - econômica, o elevado valor da causa, da condenação ou sua possível repercussão econômica, especialmente nas hipóteses de:

a) ação civil pública;

b) reclamação trabalhista com substituição processual;

c) reclamação individual cujo montante global da condenação arbitrada ou liquidada ultrapasse $\mathrm{R} \$ 500.000,00$ (quinhentos mil reais).

II - política, o possível desrespeito da instância recorrida à jurisprudência sumulada do Tribunal Superior do Trabalho ou do Supremo Tribunal Federal, ou a verbete da Orientação Jurisprudencial das Subseções Especializadas em Dissídios Individuais do Tribunal Superior do Trabalho;

III - social, a postulação, por reclamante-recorrente, de direito constitucionalmente assegurado no rol dos direitos sociais, com plausibilidade da sustentação de ofensa a inciso do art. $7^{\circ}$ da Constituição Federal;

IV - jurídica, a existência de questão nova em torno da interpretação da legislação trabalhista, ainda não submetida ao crivo de julgamento da Subseção I Especializada em Dissídios Individuais do Tribunal Superior do Trabalho.

$\S 2^{\circ}$ - Admitida a transcendência do recurso de revista, o agravo de instrumento será provido, caso preenchidos os demais pressupostos genéricos e específicos de admissibilidade do recurso de revista trancado.

$\S 3^{\circ}$ - Mantido o voto do Relator quanto à não transcendência do recurso de revista, será lavrado acórdão de desprovimento do agravo de instrumento com fundamentação sucinta.

$\S 4^{\circ}$ - Poderá o Relator denegar seguimento, monocraticamente, ao agravo de instrumento quando não atendido o pressuposto de admissibilidade do recurso de revista relativo à transcendência, cabendo agravo da decisão para a Turma.

$\S 5^{\circ}$ - A transcendência jurídica, política e social poderá ser reconhecida exclusivamente quanto a determinado tema do recurso, enquanto a transcendência econômica refere-se ao recurso no seu todo.

$\S 6^{\circ}$ - Reconhecida a transcendência parcial do recurso, será este analisado em seus pressupostos específicos de admissibilidade apenas 
quanto ao tema reputado transcendente.

Art. $2^{\circ}$ - A decisão da Turma que nega provimento a agravo de instrumento em recurso de revista ou ao agravo interposto contra decisão monocrática do Relator que denegou seguimento ao agravo de instrumento é irrecorrível no âmbito do Tribunal Superior do Trabalho.

Art. $3^{\circ}$ - O critério de transcendência somente será aplicável aos agravos de instrumento em recurso de revista interpostos após a entrada em vigor da presente Resolução.

Art. $4^{\circ}$ - O juízo de admissibilidade exercido pela Presidência dos Tribunais Regionais do Trabalho é amplo quanto aos pressupostos genéricos e específicos do recurso de revista, ficando, quanto ao critério de transcendência, limitado à verificação da existência de argüição da transcendência no recurso e da sua fundamentação, não podendo adentrar no mérito da transcendência.

Art. $5^{\circ}$ - Esta Resolução entrará em vigor 30 (trinta) dias após a sua publicação.

Brasília, 02 de agosto de 2010.

Como se vê, a Comissão da Transcendência, desta vez pelo menos, chegou a um resultado concreto e propôs o encaminhamento de anteprojeto de lei, diferentemente do que se deu com a primeira comissão incumbida de propor a regulamentação da transcendência.

E o tempo vai passando...

A conclusão a que chegou a Comissão ainda não foi submetida ao Plenário do Tribunal Superior do Trabalho, o que confirma que não é iminente uma solução para o imbróglio causado pela Medida Provisória 2226/01, inclusive porque criou aberto dissenso no seio da Corte, conquanto, reconheça-se, os Ministros do TST estejam empenhados na busca de uma solução alternativa.

E, a propósito, cabe aqui relembrar e sintetizar, ao fim deste tópico, os pontos mais importantes dos depoimentos colhidos às páginas 92 usque 124.

O Ministro Ives Gandra da Silva Martins Filho tem plena convicção de que o critério seletivo de processos, via transcendência, está em sintonia com o que acontece no resto do mundo com as Cortes Supremas e Constitucionais, o que foi reforçado em seu voto vencido. O exemplo estrangeiro, todavia, que não seria de todo aplicável ao TST, pois 
ele não está no vértice do Poder Judiciário e isso já foi destacado pela então Deputada Zulaê Cobra (p.76 supra), ao tratar do PL 3267/2000, cuja exposição de motivos não mencionava, uma única vez, sequer, o TST, que estava exclusivamente envolvido na discussão.

De outro lado, o Ministro Ives justificou o uso de medida provisória porque o Congresso Nacional havia rejeitado a urgência constitucional apresentada com o Projeto de Lei 3267/2000. Isto, no entanto, não constitui um fundamento plausível para a edição da MP 2226/01, pois conspiraria contra a independência dos poderes.

É elementar que o Parlamento não está obrigado a aceitar a urgência invocada pelo Poder Executivo no oferecimento de algum projeto de lei. E, basta ver que nas próprias medidas provisórias, até mesmo a urgência e a relevância podem não ser reconhecidas e daí cair por terra, liminarmente, a iniciativa isolada do Executivo.

Num ponto, todavia, tem muita perspicácia a observação do Ministro Ives quando constata que um bom número de advogados não tem interesse na diminuição dos recursos que tramitam em Brasília, haja vista a reserva do respectivo mercado de trabalho; também é contundente a alusão a uma "transcendência branca" porque, da maneira como é o afluxo de 1000 processos por mês no TST, "é o assessor que está decidindo" (p.95), aberração que ocorre na prática, com indevida delegação de jurisdição.

Finalmente, tocou noutro ponto crucial: a displicência do despacho-padrão de admissibilidade dos recursos de revista por parte dos Tribunais Regionais do Trabalho, que não cumprem a jurisprudência do TST e jogam "para cima" o processo (p. 96) e tem ocorrido que, na prática, tais despachos são confirmados nos julgamentos dos agravos de instrumento, sem qualquer acréscimo.

A Ministra Cristina Peduzzi, conquanto se manifeste abertamente contra a transcendência, está preocupada com a demanda processual do TST e busca soluções.

Começa por dizer que a experiência da Suprema Corte Americana não é aplicável no Brasil, pois nossa Constituição exige fundamentação de todas as decisões do Poder Judiciário e, de qualquer forma, o TST não se confunde com o STF.

Acredita que o critério da transcendência conspira contra a celeridade, primeiro porque não se sabe qual órgão fracionário do TST irá dizer qual é ou, não, o processo 
dotado desse requisito (SDI ou Turma?) e, segundo, porque a subjetividade da respectiva conceituação, sob os prismas econômico, social, político e jurídico, traria mais dificuldades do que soluções (p. 97). Vê, também, incompatibilidade da transcendência com a Constituição Federal, pois esse pressuposto precederia a análise dos demais requisitos legais compromissados com o sistema federativo, ou seja, a higidez do ordenamento jurídico federal e sua interpretação.

A Ministra Peduzzi vê comprometimento da integridade da jurisdição e do devido processo legal na medida em que a transcendência permitiria o subjetivismo dos Juízes na escolha do que seria ou não seria julgado. Entre as idéias de Dworkin, a respeito da constante adaptação dos precedentes à realidade e as de Alexy, que prestigiam uma atuação quase legiferante do Tribunal Constitucional Alemão (o que, v.g., no Brasil teve influência para as soluções dos casos das algemas e do direito de greve no setor público), parecem mais adequadas as primeiras. Não pode ser desfeito o compromisso do Juiz com o ordenamento jurídico na sua integridade, sendo arriscado que ele se transforme no senhor do processo e no senhor do recurso (p.102)

Já o Ministro Renato Lacerda Paiva destacou que razões de ordem prática impedem que se compatibilizem os quatro aspectos da transcendência (econômico, político, social e jurídico), pela evidente dificuldade de serem conceituados (p.102). Regulamentar exige objetividade e não há como se atingir um consenso a respeito da transcendência, problema concreto que mais se torna agudo no julgamento do agravo de instrumento (que nada mais é do que o reexame pelo TST do conhecimento do recurso de revista), podendo chegar-se a situações embaraçosas e inúteis nas quais se provê o agravo (inclusive para o chamado melhor exame) e, depois, não se julga a revista porque desprovida de transcendência (fl.104). Afinal, este requisito só vem posto para a revista e, não, para o agravo, daí a necessidade de construir uma solução para um problema que não foi visto pela Medida Provisória.

Por sua vez, o Ministro Lélio Bentes principia ponderando que não seria correto buscar soluções que implicassem tornar o processo de entrega da prestação jurisdicional menos humano. A missão do julgador não é exterminar processos (p.105). A crise por que passa o TST não está só nesta ponta da corda, mas, também, no seu outro lado, ou seja, a alta litigância em primeiro grau, que é consequência da falta de vigilância e fiscalização do cumprimento da legislação trabalhista por parte do 
Estado. A cultura de sonegar direitos deve ser combatida, além do que é inconcebível que o empregador tenha lucro com a demora da solução judicial. As comissões de conciliação prévia não deram certo pela ganância de quem as controla, cobrando (20\%) do empregado e do empregador, como ocorreu em caso concreto julgado no TST. E o sistema trabalhista como um todo não pode conviver com 13.000 sindicatos (p.106). Por isso é que seria imprescindível atribuir aos sindicatos a missão de supervisionar as conciliações de uma maneira minimamente séria.

No entender do Ministro Lélio, o Estado Brasileiro não ataca as causas dos conflitos e, por isso, a Justiça do Trabalho só fica com as consequências más. De outro lado, deixar nas mãos dos Juízes a seleção do que deve ser julgado comprometeria a credibilidade da própria função da Justiça do Trabalho (p.106), bastando lembrar a dificuldade do critério de transcendência econômica, que, em situações pontuais, poderia alijar de julgamentos casos envolvendo empregados domésticos, rurais, trabalho infantil e escravo.

Se é quase impossível construir um critério positivo de transcendência, propugna o Ministro Lélio, talvez, pela adoção de um critério de instranscendência, mais transparente para as partes e advogados se, por exemplo, partir-se da jurisprudência sumulada ou iterativa. Se o recurso está em sintonia com a jurisprudência do TST não é transcendente. E isso poderia começar com os agravos, que não tem sustentação oral. E, no entender do Ministro, um ponto que mereceria atenção maior é o da uniformização interna da jurisprudência do Regionais, o que não acontece e, de uma forma ou de outra, acaba sendo feito pelo TST, desnecessariamente (p.112).

O Ministro Pedro Paulo Manus observou, de início, que a transcendência foi estigmatizada porque teve origem em medida provisória. A situação dos processos do TST é diversa daquela do STF e do STJ em razão da multiplicidade de matérias recursais trazidas pelas partes; "quando tem pouco, tem três ou quatro temas" (p. 112). De outro lado, sobressai a grande dificuldade de operacionalizar o julgamento da própria transcendência, não se sabendo se será incumbência do Relator, sozinho (se negar cabe agravo?), se da Turma (com agravo para a SDI?), enfim, não se vê como a adoção desse critério irá agilizar os processos. 
O Ministro Pedro Paulo Manus toca em ponto já conhecido e que exige providências: a cultura recursal das partes e dos advogados, o primeiro aspecto referente às pessoas de direito público, que mais figuram como recorrentes, e os advogados, que manejam recursos, embargos e agravos com a nítida intenção de protelar a solução do litígio. O "eixo da recorribilidade" haveria de mudar (p.114), não sendo suficiente insistir no efeito meramente devolutivo da revista, pois aí sobrevêm as ações cautelares. A grande iniciativa para diminuir os processos na Justiça do Trabalho e, de consequência, no TST estaria na busca de medidas extrajudiciais, onde a quitação tenha mais respeito e eficácia.

O Ministro Luiz Philippe, tal como fez o colega Lélio Bentes, insiste em que se deve fazer um correto diagnóstico do acúmulo de processos no TST; hão de ser atacadas as causas, não as consequências, daí por que lhe parece que o problema não está no TST, mas nos Tribunais Regionais do Trabalho, “que se tornaram tribunais de passagem" (p.118). Eles não uniformizam sua jurisprudência interna e, com isso, comprometem a segurança jurídica e desestimulam a conciliação. Só tem algum valor a sentença e a última decisão do TST, daí recaindo nas costas deste o custo da demora na prestação jurisdicional.

Assim, a primeira providência que deve ser tomada pelo TST, no entender do Ministro Luiz Philippe, é o encaminhamento de anteprojeto de lei que obrigue o Tribunal Regional a uniformizar a interpretação da lei.

Contra a decisão do Regional em recurso ordinário não caberia, de plano, a revista, como é hoje, mas embargos de divergência para uma sessão especializada “e essa sessão deverá dizer, desde que comprovada a divergência, que a posição do Tribunal, quanto àquele dispositivo de lei federal, naquela hipótese submetida a exame, é em tal ou qual sentido, razão pela qual eu vou eliminar todas as múltiplas decisões sobre o mesmo caso, criando insegurança regional e fazendo do Tribunal Superior um órgão de revisão e, não, um órgão de uniformização” (p.119/120).

É preciso que se busque a segurança jurídica no âmbito do Regional, de modo a que o Juiz de primeiro grau e as partes comecem a prestigiar a jurisprudência local.

O que acontece hoje é que o TST está uniformizando a jurisprudência interna dos Regionais a partir de divergência de outro Tribunal, o que não tem sentido e refoge dos propósitos de ser do Tribunal Superior. 
E, quanto à transcendência em si, o Ministro Luiz Philippe lembra a circunstância de que nenhum Tribunal "estabeleceu requisito de admissibilidade por si próprio" (p.121); seria atribuir ao TST a possibilidade de legislar sobre processo (requisito de admissibilidade de recurso), o que a OAB dificilmente aceitaria. "Regulamentar critérios da transcendência não significa criar pressupostos subjetivos". E, no julgamento da liminar da ADI 2527, "a inconstitucionalidade rejeitada foi formal, mas a material ainda não foi excluída.”(p.121).

A notória dificuldade de conceituação do que é transcendente talvez possa ensejar a aceitação do critério de intranscendência, o qual, escapando dos subjetivismos, seria evidente às partes e aos advogados quando partisse da jurisprudência fixada pelo STF e pelo TST, ou seja, se a matéria já está uniformemente julgada ou sumulada ela jamais alcançaria transcendência. "Se decidiu de acordo com a súmula, acabou. Acabou em primeiro grau. Não precisa entrar com recurso. Se recorrer é litigância de má-fé. Então, é possível que se faça uma série de conformações de ordem legislativa e aqui, internamente, apenas como juízo objetivo-negativo, mas nunca um juízo positivosubjetivo"(p.123).

Por fim, o Ministro Walmir Oliveira da Costa, em síntese, entende que "a transcendência, tal como idealizada, não atenderia a finalidade para a qual foi dirigida e proposta;" "ela criaria mais conflitos do que solucionaria o processo". A transcendência é por demais subjetiva, daí sugerir um critério objetivo da seguinte forma: "Nós diríamos que possui transcendência econômica, social, política e jurídica todas as decisões, ou melhor dizendo, todos os recursos nos quais as decisões dos tribunais regionais fossem contrárias a súmula de direito material e orientação jurisprudencial do TST, ou seja, quando a decisão regional negar aplicabilidade a súmula de direito material ou orientação jurisprudencial de direito material caberia recurso de revista. Ao contrário, o recurso não seria transcendente do ponto de vista econômico, jurídico, político e social." (p.124).

Entende Sua Excelência que poderia ser aproveitada a oportunidade de regulamentação da transcendência para a criação de mecanismos objetivos da admissibilidade do recurso de revista, exigindo da parte, por exemplo, tal como está na Súmula 337/TST, que ela demonstre aonde está nas ementas colecionadas o conflito de teses, não bastando sua mera transcrição, o que "poderia ser considerado como um 
critério técnico-jurídico de não admissibilidade, por falta de transcendência também"(p.124).

A síntese dos depoimentos colhidos revela a preocupação de todos os Ministros do Tribunal Superior do Trabalho com a relevante função que lhes é exigida pela sociedade. A regulamentação da transcendência, ainda que não aconteça, abre uma oportunidade para que aqueles que vivem o dia a dia dos julgamentos (e que não estão de acordo com a situação atual) possam prestar sua contribuição, principalmente para alertar sobre desvios mais encontradiços nos dias de hoje (destacam-se no mínimo dois) e que muito contribuem para o acréscimo dos recursos de revista: a prática recursal inconsequente e a falta de segurança jurídica nos Tribunais Regionais do Trabalho, que não unificam sua jurisprudência, com isso desestimulando a conciliação.

\subsection{A Alternativa}

Neste último tópico impõe-se considerar se, afinal, a transcendência, concebida como filtro processual (verdadeira barreira de contenção) dos recursos de revista, mereceria subsistir como tal, desde que superado o problema da inconstitucionalidade de sua criação por meio de medida provisória.

E, para tanto, não se pode fugir de um dado incontornável: o avassalador número de processos recebidos pela Justiça do Trabalho, desde o primeiro grau de jurisdição, que nunca diminui, e, particularmente, o número de recursos de revista interpostos para o Tribunal Superior do Trabalho, tendo igual significação os agravos de instrumentos oferecidos contra a denegação dos recursos de revista pelos Tribunais Regionais do Trabalho.

Conforme informações obtidas junto ao próprio Tribunal Superior do Trabalho, encontráveis no Relatório Geral da Justiça do Trabalho para o ano 2009, a carga de trabalho por magistrado, nesta Justiça Especializada, foi de 2.263 processos, isto significando um aumento de $0,17 \%$ em relação a 2008 . 
No Tribunal Superior do Trabalho, a carga para cada Ministro foi de 15.271 processos; foram solucionados 265.802 processos, 19,0\% a mais do que em 2008 e 64,5\% do total que restava para julgar.

Cada Ministro solucionou, em média, 1.108 processos por mês.

Do total de processos solucionados, 146.664, correspondente a 55,2\%, referem-se a Agravos de Instrumento em Recurso de Revista e 61.876, correspondente a 23,3\%, dizem respeito, propriamente, aos Recursos de Revista. Foram solucionados 5 Dissídios Coletivos, sendo 2 por acordo em audiência de conciliação. Os Órgãos Judicantes do TST realizaram 403 sessões de julgamento no ano, ou 40 sessões por mês, aproximadamente. A média de processos julgados por sessão foi de 660 .

No TST, $11,89 \%$ das decisões monocráticas foram agravadas, $43,25 \%$ a mais que em 2008.

Houve oposição de Embargos Declaratórios em 9,55\% dos acórdãos e despachos publicados, $8,40 \%$ a mais que no ano anterior.

A interposição dos recurso de Embargos (de divergência entre as Turmas e a SDI) ocorreu em 5,76\% dos acórdãos e despachos publicados, 10,08\% a mais que em 2008. ${ }^{434}$

As tabelas abaixo, também retiradas da página mantida pelo TST na internet, demonstram a evolução da movimentação processual na referida Corte, ao longo dos anos. Há ainda dados específicos relativos aos recursos de revista e agravos de instrumento em recursos de revista autuados e julgados entre os anos de 1999 e 2008.

MOVIMENTAÇÃo TOTAL DE PROCESSOS, POR ANO, NO TST ${ }^{435}$

\begin{tabular}{|l|l|l|l|}
\hline Desde 1941 \\
\hline \multirow{2}{*}{ Ano } & \multicolumn{3}{l|}{ Processos } \\
\cline { 2 - 5 } & Recebidos & Julgados & Resíduo \\
\hline $\begin{array}{l}2010- \\
\text { outubro }\end{array}$ & 164.486 & 178.606 & 170.835 \\
\hline 2009 & 206.236 & 265.802 & 172.732 \\
\hline
\end{tabular}

\footnotetext{
${ }^{434}$ TRIBUNAL SUPERIOR DO TRABALHO. Relatório Geral da Justiça do Trabalho - 2009. Disponível em: <http://www.tst.gov.br/Sseest/RGJT/Rel2009/JT2009/rel2009.pdf>. Acesso em: 19 out. 2010.

${ }^{435}$ TRIBUNAL SUPERIOR DO TRABALHO. Processos. Disponível em: <http://www.tst.jus.br/Sseest/JT1941/TST1941/TST1941.htm>. Acesso em: 19 out. 2010.
} 


\begin{tabular}{|l|l|l|l|}
\hline 2008 & 183.235 & 223.430 & 206.089 \\
\hline 2007 & 165.466 & 153.592 & 249.316 \\
\hline 2006 & 145.053 & 135.718 & 244.331 \\
\hline 2005 & 117.203 & 134.269 & 227.424 \\
\hline 2004 & 133.107 & 116.653 & 246.743 \\
\hline 2003 & 121.921 & 97.455 & 224.495 \\
\hline 2002 & 115.694 & 87.635 & 195.912 \\
\hline 2001 & 114.615 & 102.788 & 159.400 \\
\hline 2000 & 125.484 & 98.808 & 153.906 \\
\hline 1999 & 115.870 & 121.181 & 135.933 \\
\hline 1998 & 131.415 & 111.814 & 143.618 \\
\hline 1997 & 91.853 & 87.607 & $\ldots$ \\
\hline 1996 & 106.730 & 57.863 & $\ldots$ \\
\hline 1995 & 93.484 & 56.033 & $\ldots$ \\
\hline 1994 & 65.792 & 44.695 & $\ldots$ \\
\hline 1993 & 34.408 & 35.938 & $\ldots$ \\
\hline 1992 & 24.758 & 28.447 & $\ldots$ \\
\hline 1991 & 22.039 & 24.713 & $\ldots$ \\
\hline 1990 & 20.276 & 20.473 & $\ldots$ \\
\hline 1989 & 19.201 & 23.812 & $\ldots$ \\
\hline 1988 & 17.607 & 17.600 & $\ldots$ \\
\hline 1987 & 16.157 & 21.178 & $\ldots$ \\
\hline 1986 & 18.822 & 21.304 & $\ldots$ \\
\hline 1985 & 19.541 & 23.010 & $\ldots$ \\
\hline 1984 & 15.958 & 16.726 & $\ldots$ \\
\hline 1983 & 14.884 & 16.085 & $\ldots$ \\
\hline 1982 & 14.483 & 14.474 & $\ldots$ \\
\hline 1981 & 13.060 & 15.372 & $\ldots$ \\
\hline 1980 & 14.466 & 13.915 & $\ldots$ \\
\hline 1979 & 17.058 & 11.706 & $\ldots$ \\
\hline 1978 & 15.509 & 12.265 & $\ldots$ \\
\hline 1977 & 15.647 & 13.387 & $\ldots$ \\
\hline 1976 & 13.871 & 11.723 & $\ldots$ \\
\hline 1975 & 11.371 & 9.248 & $\ldots$ \\
\hline 1974 & 9.887 & 8.261 & $\ldots$ \\
\hline 1973 & 9.522 & 8.994 & $\ldots$ \\
\hline 1972 & 9.434 & 7.845 & $\ldots$ \\
\hline 1971 & 8.029 & 6.586 & $\ldots$ \\
\hline 1970 & 8.813 & 7.803 & $\ldots$ \\
\hline 1969 & 7.083 & 5.872 & $\ldots$ \\
\hline & & & \\
\hline
\end{tabular}




\begin{tabular}{|c|c|c|c|}
\hline 1968 & 7.219 & 6.855 & $\ldots$ \\
\hline 1967 & 7.813 & 8.442 & $\ldots$ \\
\hline 1966 & 9.626 & 9.053 & $\ldots$ \\
\hline 1965 & 9.372 & 9.868 & $\ldots$ \\
\hline 1964 & 10.400 & 9.561 & $\ldots$ \\
\hline 1963 & 9.047 & 7.930 & $\ldots$ \\
\hline 1962 & 8.368 & 7.779 & $\ldots$ \\
\hline 1961 & 8.364 & 8.450 & $\ldots$ \\
\hline 1960 & 7.962 & 7.190 & $\ldots$ \\
\hline 1959 & 6.565 & 6.450 & $\ldots$ \\
\hline 1958 & 5.895 & 5.490 & $\ldots$ \\
\hline 1957 & 5.035 & 4.492 & $\ldots$ \\
\hline 1956 & 3.877 & 3.743 & $\ldots$ \\
\hline 1955 & 3.154 & 6.229 & $\ldots$ \\
\hline 1954 & 2.875 & 3.694 & $\ldots$ \\
\hline 1953 & 2.884 & 2.286 & $\ldots$ \\
\hline 1952 & 2.970 & 1.886 & $\ldots$ \\
\hline 1951 & 2.770 & 2.368 & $\ldots$ \\
\hline 1950 & 2.755 & 2.403 & $\ldots$ \\
\hline 1949 & 3.154 & 2.013 & $\ldots$ \\
\hline 1948 & 2.700 & 2.137 & $\ldots$ \\
\hline 1947 & 2.392 & 1.850 & $\ldots$ \\
\hline 1946 & 1.934 & 1.869 & $\ldots$ \\
\hline 1945 & 1.169 & 1.137 & $\ldots$ \\
\hline 1944 & 885 & 867 & $\ldots$ \\
\hline 1943 & 570 & 546 & $\ldots$ \\
\hline 1942 & 408 & 400 & $\ldots$ \\
\hline 1941 & 160 & 148 & $\ldots$ \\
\hline Total & 2.697 .402 & 2.577 .053 & $\ldots$ \\
\hline
\end{tabular}

AGRA VO DE INSTRUMENTO EM RECURSO DE REVISTA ${ }^{436}$

\begin{tabular}{|l|l|l|}
\hline \multicolumn{1}{|c|}{ Anos } & Autuados & Julgados \\
\hline 1999 & 45.605 & 72.392 \\
\hline 2000 & 54.103 & 41.126 \\
\hline 2001 & 59.676 & 29.053 \\
\hline 2002 & 64.324 & 23.780 \\
\hline 2003 & 71.285 & 40.184 \\
\hline
\end{tabular}

${ }^{436}$ TRIBUNAL SUPERIOR DO TRABALHO. Dados Demonstrativos. Disponível em: <http://www.tst.jus.br/Sseest/RGJT/Rel2009/TST2009/TST2008.pdf>. Acesso em: 19 out. 2010. 


\begin{tabular}{|l|l|l|}
\hline 2004 & 71.758 & 53.691 \\
\hline 2005 & 61.233 & 68.023 \\
\hline 2006 & 92.661 & 71.533 \\
\hline 2007 & 66.908 & 78.382 \\
\hline 2008 & 139.718 & 135.382 \\
\hline
\end{tabular}

\section{AGRAVO DE INSTRUMENTO EM RECURSO DE REVISTA E RECURSO DE REVISTA $^{437}$}

\begin{tabular}{|l|l|l|}
\hline \multicolumn{1}{|c|}{ Anos } & Autuados & Julgados \\
\hline 1999 & 8 & - \\
\hline 2000 & 1.378 & 1 \\
\hline 2001 & 2.105 & 102 \\
\hline 2002 & 2.224 & 311 \\
\hline 2003 & 2.880 & 574 \\
\hline 2004 & 95 & 628 \\
\hline 2005 & 6 & 690 \\
\hline 2006 & 103 & 1.140 \\
\hline 2007 & 192 & 910 \\
\hline 2008 & 237 & 1.790 \\
\hline
\end{tabular}

\section{RECURSO DE REVISTA ${ }^{438}$}

\begin{tabular}{|l|l|l|}
\hline \multicolumn{1}{|c|}{ Anos } & Autuados & Julgados \\
\hline 1999 & 43.008 & 19.889 \\
\hline 2000 & 38.406 & 18.409 \\
\hline 2001 & 27.493 & 30.500 \\
\hline 2002 & 24.107 & 28.743 \\
\hline 2003 & 23.673 & 27.992 \\
\hline 2004 & 28.762 & 27.677 \\
\hline 2005 & 27.422 & 29.820 \\
\hline 2006 & 32.362 & 27.222 \\
\hline 2007 & 25.636 & 39.181 \\
\hline 2008 & 46.922 & 43.651 \\
\hline
\end{tabular}

Dentro desse quadro numérico assustador, pelo menos mais recentemente, não se pode dizer que o Tribunal Superior do Trabalho tenha-se mantido alheio ao problema.

\footnotetext{
${ }^{437}$ TRIBUNAL SUPERIOR DO TRABALHO. Disponível em: <http://www.tst.jus.br/Sseest/RGJT/Rel2009/TST2009/TST2008.pdf>. Acesso em: 19 out. 2010.

${ }^{438}$ Id. Ibid.
} 
Vê-se, de um lado, a tenacidade e a fidelidade de propósitos do Ministro Ives Gandra da Silva Martins Filho, como se sabe, um dos idealizadores da transcendência, ainda quando atuava como assessor na Subchefia da Casa Civil da Presidência da República $^{439}$, ao lado do Ministro Gilmar Ferreira Mendes, que também exibe seu DNA na paternidade da repercussão geral e da disciplina das ações declaratórias de constitucionalidade e das declaratórias de inconstitucionalidade, com destaque para o efeito erga omnes e a ratio decidendi vinculante.

De outro lado, tal como se extraiu dos depoimentos prestados nas entrevistas, os Ministros do Tribunal Superior do Trabalho estão na busca de uma solução para o crescente número de processos que para lá afluem, constituindo a mais recente proposta concreta para tratar desse problema, ainda inédita, o anteprojeto de lei abaixo apresentado, que não se limita ao recurso de revista, mas, cuida de quase a totalidade do sistema recursal trabalhista. Este anteprojeto foi oferecido pela última Comissão da Transcendência (RA 1360/09) criada para regulamentá-la, mas, sustentando sua impossibilidade prática, propõe uma alternativa . Veja-se o seu teor: 440

\section{ANTEPROJETO DE LEI N ${ }^{\circ}$}

Dispõe sobre o processamento de recursos no âmbito da Justiça do Trabalho e dá outras providências.

Art. $1^{\circ}$. Os arts. 894, 896, 897-A e 899 do Decreto-Lei n. ${ }^{\circ} 5.452$, de $1^{\circ}$ de maio de 1943 - Consolidação das Leis do Trabalho, passam a vigorar com a seguinte redação:

“Art. 894. (...)

II - das decisões das Turmas que divergirem entre si ou das decisões proferidas pela Seção de Dissídios Individuais, ou contrárias a Súmula ou orientação jurisprudencial do Tribunal Superior do Trabalho ou Súmula Vinculante do Supremo Tribunal Federal.

III - (omite-se)

$\S 1^{\circ}$. A divergência apta a ensejar os Embargos deve ser atual, não se considerando tal a ultrapassada por súmula do Tribunal Superior do Trabalho ou do Supremo Tribunal Federal, ou superada por iterativa e notória jurisprudência do Tribunal Superior do Trabalho.

\footnotetext{
${ }^{439}$ Dado confirmado no sítio do TRIBUNAL SUPERIOR DO TRABALHO. Ministros do TST. Disponível em: <http://www.tst.jus.br/ASCS/ministro.html>. Acesso em: 19 out. 2010.

${ }^{440} \mathrm{O}$ Ministro João Oreste Dalazen, Vice-Presidente do Tribunal Superior do Trabalho e Presidente da Comissão encarregada de regulamentar a transcendência, autora do anteprojeto de lei, permitiu o uso deste material para fins acadêmicos.
} 
$\S 2^{\circ} \mathrm{O}$ Ministro Relator denegará seguimento aos embargos e imporá à parte multa de até $10(\mathrm{dez})$ por cento sobre o valor da causa corrigido, em proveito da parte contrária:

I - se a decisão recorrida estiver em consonância com Súmula da Jurisprudência do Tribunal Superior do Trabalho ou do Supremo Tribunal Federal, ou com iterativa, notória e atual jurisprudência do Tribunal Superior do Trabalho, cumprindo-lhe indicá-la;

II - nas hipóteses de intempestividade, deserção, irregularidade de representação ou de ausência de qualquer outro pressuposto extrínseco de admissibilidade;

$\S 3^{\circ}$. Da decisão denegatória cabe agravo, no prazo de 8 (oito) dias.

$\S 4^{\circ}$. Quando manifestamente inadmissível ou infundado o agravo, a Seção de Dissídios Individuais condenará o agravante a pagar ao agravado multa entre 10 (dez) e 15 (quinze) por cento do valor da causa corrigido, ficando a interposição de qualquer outro recurso condicionada ao depósito do respectivo valor.

“Art. 896. (...)

a) derem ao mesmo dispositivo de lei federal interpretação diversa da que lhe houver dado outro Tribunal Regional do Trabalho, no seu Pleno ou Turma, ou a Seção de Dissídios Individuais do Tribunal Superior do Trabalho, ou que contrariarem Súmula de Jurisprudência Uniforme dessa Corte ou Súmula Vinculante do Supremo Tribunal Federal;

$\S 1^{\circ} \mathrm{O}$ Recurso de Revista, dotado de efeito apenas devolutivo, será interposto perante o Presidente do Tribunal Regional do Trabalho, que, por decisão fundamentada, poderá recebê-lo ou denegá-lo.

$\S 1^{\circ}$-A. Sob pena de não conhecimento, é ônus da parte:

I - indicar o trecho da decisão recorrida que consubstancia o prequestionamento da controvérsia objeto do recurso de revista;

II - indicar, de forma explícita e fundamentada, contrariedade a dispositivo de lei, súmula ou orientação jurisprudencial do TST que conflite com a decisão regional;

III - expor as razões do pedido de reforma, impugnando todos os fundamentos jurídicos da decisão recorrida, inclusive mediante demonstração analítica de cada dispositivo de lei, da Constituição Federal, de súmula ou de orientação jurisprudencial cuja contrariedade aponte;

$\S 2^{\circ}$. (omite-se)

$\S 3^{\circ}$ Os Tribunais Regionais do Trabalho procederão, obrigatoriamente, à uniformização de sua jurisprudência e aplicarão nas causas da competência da Justiça do Trabalho, no que couber, o incidente de resolução de demandas repetitivas previsto no $\mathrm{CPC}$, não servindo a eventual súmula ou a tese aprovada sobre a questão jurídica controvertida, no julgamento do incidente, para ensejar a 
admissibilidade do Recurso de Revista quando contrariar Súmula ou Orientação Jurisprudencial do TST.

$\S 4^{\circ}$. Ao constatar o Tribunal Superior do Trabalho, de ofício ou mediante provocação de qualquer das partes ou do Ministério Público do Trabalho, a existência de decisões conflitantes no âmbito do mesmo Tribunal Regional do Trabalho, sobre o tema objeto do recurso de revista, determinará o retorno dos autos à Corte de origem, a fim de que proceda à uniformização da jurisprudência.

$\S 5^{\circ}$. A providência a que se refere o parágrafo anterior poderá ser determinada monocraticamente pelo Relator ou pelo Presidente do Tribunal Regional do Trabalho, mediante decisão irrecorrível, ao emitir juízo de admissibilidade sobre o recurso de revista.

$\S 6^{\circ}$. Após o julgamento do incidente a que se refere $\mathrm{o} \S \mathbf{3}^{\circ}$, unicamente a súmula regional ou a tese jurídica prevalecente no Tribunal Regional do Trabalho e não conflitante com Súmula ou Orientação Jurisprudencial do TST serve como paradigma para viabilizar o conhecimento do $\mathbf{R R}$, por divergência.

$\S 7^{\mathbf{0}}$ A divergência apta a ensejar o Recurso de Revista deve ser atual, não se considerando tal a ultrapassada por súmula do Tribunal Superior do Trabalho ou do Supremo Tribunal Federal, ou superada por iterativa e notória jurisprudência do Tribunal Superior do Trabalho.

$\S 8^{\circ}$ Quando o recurso fundar-se em dissenso de julgados, incumbe ao recorrente o ônus de produzir prova da divergência jurisprudencial, mediante certidão, cópia ou citação do repositório de jurisprudência, oficial ou credenciado, inclusive em mídia eletrônica, em que houver sido publicada a decisão divergente, ou ainda pela reprodução de julgado disponível na Internet, com indicação da respectiva fonte, mencionando, em qualquer caso, as circunstâncias que identifiquem ou assemelhem os casos confrontados.

$\S 9^{\mathbf{0}}$ Nas causas sujeitas ao procedimento sumaríssimo, somente será admitido recurso de revista por contrariedade a súmula de jurisprudência uniforme do Tribunal Superior do Trabalho e violação direta da Constituição da República.

Art. 896-B. O Ministro Relator denegará seguimento ao recurso de revista ou ao agravo de instrumento:

I - se a decisão recorrida estiver em consonância com a iterativa, notória e atual jurisprudência do Tribunal Superior do Trabalho, ou com Súmula ou Orientação Jurisprudencial do Tribunal Superior do Trabalho, ou Súmula do Supremo Tribunal Federal, cumprindo ao Relator indicá-la;

II - nas hipóteses de intempestividade, deserção, irregularidade de representação, ou de ausência de qualquer outro pressuposto extrínseco de admissibilidade;

$\S 1^{\circ}$. Da decisão denegatória cabe agravo, no prazo de 8 (oito) dias. 
$\S 2^{\circ}$. Quando manifestamente inadmissível ou infundado o agravo, assim declarado em votação unânime, a Turma condenará o agravante a pagar ao agravado multa entre 1 (um) e 10 (dez) por cento do valor corrigido da causa, em proveito da parte contrária, fixando-a desde logo, condicionada a interposição de qualquer outro recurso ao depósito do respectivo valor.

Art. 896-C. Aplicam-se ao recurso de revista, no que couberem, as normas do Código de Processo Civil que regem o julgamento dos recursos extraordinário e especial repetitivos.

“Art. 897-A. (...)

$\S \mathbf{1}^{\circ}$ Os erros materiais poderão ser corrigidos de ofício ou a requerimento de qualquer das partes.

$\S 2^{\circ}$. Eventual efeito modificativo dos Embargos de Declaração somente poderá ocorrer em virtude da correção de vício na decisão embargada e desde que ouvida a parte contrária, no prazo de cinco dias.

$\S 3^{\circ}$ Salvo quando intempestivos, os Embargos de Declaração interrompem o prazo para interposição de outros recursos, por qualquer das partes.

$\S 4^{\circ}$ Quando manifestamente protelatórios os embargos, o juiz ou o tribunal condenará o embargante a pagar ao embargado multa, em montante líquido desde logo fixado, não excedente a cinco por cento sobre o valor corrigido da causa.

$\S 5^{\circ}$ Não serão admitidos novos Embargos de Declaração, se os anteriores interpostos contra a mesma decisão houverem sido considerados protelatórios, sujeitando-se a parte à multa de até 10 (dez) sobre o valor corrigido da causa, em montante líquido desde logo fixado.

$\S 6^{\circ} \mathrm{A}$ interposição de qualquer outro recurso fica condicionada ao depósito do valor de cada multa, ressalvados a Fazenda Pública e os beneficiários de justiça gratuita.

Art. 899. Os recursos serão interpostos no prazo de 8 (oito) dias, em petição fundamentada, e terão efeito devolutivo, salvo as exceções previstas neste Título, permitida a execução provisória até a penhora.

\section{$(\ldots)$}

$\S 7^{\circ}$ - Sob pena de não conhecimento do recurso, na hipótese de mandato tácito o recorrente indicará a ata de audiência que o configura."

Art. $2^{\circ}$. O Tribunal Superior do Trabalho é competente para processar e julgar reclamação para a preservação de sua competência e a autoridade de suas decisões.

Parágrafo único. O processamento e julgamento da reclamação serão regulados pelo regimento interno do Tribunal Superior do Trabalho. 
Art. $3^{\circ}$. Quando o recurso tempestivo for inadmissível por defeito formal que não se repute grave, o Tribunal Superior do Trabalho poderá desconsiderar o vício e julgar o mérito de casos repetitivos ou sempre que a decisão da questão de mérito contribua para o aperfeiçoamento do sistema jurídico.

Art. $4^{\circ}$. Esta Lei entra em vigor 60 (sessenta) dias após a sua publicação.

Art. 5ํ. Revogam-se as disposições em contrário.

Brasília, 30 de junho de $2010^{441}$

Como se vê, está abandonada a idéia de adoção de um novo critério prevalente ou pressuposto específico para o recurso de revista, nos moldes da transcendência do art. 896A da CLT, ou, ainda, sob o prisma da antiga relevância ou da vigente repercussão geral. Só o art. $3^{\circ}$ que traz alguma lembrança do instituto pretendido.

De fato, tal como asseverou o Ministro João Oreste Dalazen no voto que prevaleceu na Comissão da Transcendência, ela não se viabiliza como pressuposto específico porque não se harmoniza com os outros requisitos há muito existentes no art. 896 da CLT (divergência e violação de lei, basicamente).

Ou a transcendência transforma-se em critério único de admissão do recurso de revista ou haverá necessidade de conviver com os históricos pressupostos intrínsecos de cabimento do recurso de revista. A transcendência é vista, portanto, como quebra muito grave do padrão legal que vem sendo perfilado há tantos anos.

Paralelamente, embora o art. 896-A da CLT aluda a exame prévio da transcendência da causa, não faz o menor sentido e conspira contra a celeridade e a utilidade, que norteiam o processo em geral e o trabalhista em particular, repita-se, é perda de tempo debruçar-se sobre a transcendência em si mesma quando, sequer, antes, não tenham sido analisados os pressupostos extrínsecos e os intrínsecos já legalmente definidos (divergência e violação de lei). E, como muito bem lembrado no voto prevalente, o STF, ao tratar da repercussão geral, precisamente no art. 323 do seu Regimento Interno,

\footnotetext{
${ }^{441} \mathrm{O}$ negrito, que consta do original do anteprojeto, destaca a nova redação ou acréscimos ocorridos nos artigos da CLT que tratam do recurso de revista (art. 896), do recurso de embargos (art. 894), dos embargos de declaração(art. 897-A) e dos recursos, em geral, (art.899). Este anteprojeto de lei ainda não foi submetido ao Plenário do Tribunal Superior do Trabalho.
} 
pressupõe que os requisitos extrínsecos já tenham sido analisados pelo relator, para só depois submeter o exame da repercussão aos demais Ministros.

Sua Excelência o Ministro João Oreste Dalazen, todavia, vê mais encargos do Relator e da Turma na análise prévia dos pressupostos extrínsecos e intrínsecos, com o que não se pode concordar, pois, afinal, esse exame prévio de admissibilidade é feito desde que existe o próprio recurso de revista e não representa trabalho a mais.

E, como antes assinalado, caso erigida a transcendência como pressuposto específico, conhecido o recurso, ela constituirá prejudicial da totalidade ou do restante do mérito, semelhantemente como se dá com a prescrição. E esta decisão prejudicial haveria de ser irrecorrível.

O grande obstáculo da transcendência, todavia, reside no seu conceito exageradamente indefinido e amplo, mormente quando agregado "aos reflexos gerais de natureza econômica, política, social ou jurídica”.

De fato, haveria uma forte e imponderável dose de subjetivismo na fixação do sentido e do alcance daquilo que seria transcendente sob os prismas postos na parte final do art. 896-A da CLT, isso tudo por parte das Oito Turmas que compõem o TST, daí abrindo inédita oportunidade de recurso de embargos para a SBDI-1, na hipótese de haver divergência de entendimento entre esses órgãos fracionários. Noutras palavras: poderiam diminuir os processos nas Turmas, mas, até que se construísse consenso sobre o critério da transcendência, haveria sobrecarga de recursos para a seção de dissídios individuais, sem contar nos quase compulsórios embargos de declaração que seriam opostos no caso de não ser aceita a transcendência.

E, isso não bastasse, é consabido que os recursos de revista, rara vez, exibem tema único, situação que torna muito difícil transpor a experiência que o Supremo Tribunal Federal tem vivenciado no exame da repercussão geral; aqui, quase sempre, o debate circunscreve-se a um tema só, cuja repercussão é aceita ou, não, em julgamento do Plenário (ainda que virtual) e, por certo, com número menor de julgadores.

Os vários desdobramentos práticos da questão foram minudentemente expostos no referido voto vencedor da não regulamentação da transcendência (cfr. supra fls.216-218. 
$\mathrm{O}$ argumento maior, todavia, para a rejeição desse pressuposto específico residiria na abdicação ou no esvaziamento da função precípua do Tribunal Superior do Trabalho, exatamente a uniformização da jurisprudência e a afirmação do "primado da lei federal violada na esfera de sua competência," que poderiam ser desconsiderados em casos muito frequentes e numericamente significativos, mas nos quais difícil seria vislumbrar transcendência econômica, política, social ou jurídica, tal como apontado no voto prevalente (vide supra fls. 218 e 219).

De outro lado, porém, há fundamentos ponderáveis no voto vencido do Ministro Ives Gandra da Silva Martins Filho, pelo menos no que tange à preocupação com a qualidade dos julgamentos do Tribunal Superior do Trabalho e a experiência similar vivenciada por outras tantas e respeitáveis Cortes, mundo afora, que se valem de critérios de escolha daquilo que há de ser decidido.

Antes, todavia, de se rememorarem esses fundamentos verdadeiramente importantes que expostos por Sua Excelência, hão de ser rechaçados os que pertinem à alegada constitucionalidade da Medida Provisória 2226/01, que instituiu a transcendência.

Em primeiro lugar, se a Medida Provisória 2226/01 é, de fato, Medida Provisória, só exibindo força de lei, pois lei não é, carece de sustentação constitucional dizer que ela passou a integrar, definitivamente, o ordenamento jurídico; o máximo que se pode dizer é que o respectivo prazo de vigência transformou-se, ficando indefinido no tempo. A própria EC 32/01 não pode ser entendida de outra forma, como se fora um "ato constitucional", subvertendo todo o processo legislativo constitucional.

Permitida uma irreverente metáfora, "gato que nasce em forno não é nem vira biscoito"! Ou seja, aquilo que nasce sob condição resolutiva, não pode consolidar-se sem que a condição seja realizada.

E, ainda: é incompatível com o Estado Democrático a criação de norma jurídica que deixe de ser submetida ao Poder Legislativo; a reserva de Parlamento, a que aludiu o Ministro Celso de Mello, é incontornável, sob pena de se admitir a criação de lei por ato unipessoal do Presidente da República, o que é absurdo supor. 
Em segundo lugar, é prematuro dizer que o Supremo Tribunal Federal tenha reputado constitucional o art. 896-A da CLT. Tem-se, até agora, apenas o julgamento da medida cautelar da MC-ADI 2257-9; não há decisão definitiva.

Além disso, esse julgamento da medida cautelar da ADI foi tão confuso e tão demorado (levou mais de seis anos para ser ultimado) que, se houver coerência com os precedentes da própria Suprema Corte, fartamente antes invocados, se for aplicada a ratio decidendi da ADI 1910, acredita-se que poderá haver a reversão do entendimento majoritário a que chegou o STF em sede preliminar.

Em terceiro lugar, com todo o respeito devido ao prolator do voto vencido, causa surpresa o argumento segundo o qual não se deveria rejeitar a inovação da transcendência só porque veiculada por medida provisória, pois a própria Consolidação das Leis do Trabalho teria sido "instituída mediante decreto-lei, ato também oriundo de atividade legiferante do Poder Executivo" (..., fl. 220).

A alegação não convence e, até, constrange porque, em maio de 1943, o Brasil não vivia democracia e o Congresso Nacional estava fechado, situação que difere, radicalmente, daquela que acontecia em 2001.

Bem por isso é que não se consegue admitir a existência de poder legiferante, de forma incondicionada e irrestrita, ao Presidente da República, como tal veio praticada na MP 2226/01 e, ainda, como se disse à fl.200, do mesmo modo que se deu com a MP218035, que ampliou prazo para a Fazenda Pública embargar execução e relativizou a coisa julgada (art. 884 da CLT), o que tanta celeuma, incerteza e confusões tem trazido nos milhares processos em curso, muitos deles paralisados, aguardando a decisão final do STF, que já tarda mais de três anos.

O Ministro Ives Gandra da Silva Martins Filho, porém, tem boas razões ao dizer que o sistema dos processos repetitivos, usado no STJ (e no STF), não tem condições de ser transposto para o TST, pois, (isso é reconhecido no voto prevalente), a múltipla temática recursal da revista difere da maioria dos casos do STJ, nos quais prevalece matéria única, igual e repetida, que deve ser julgada (v. g. casos do INSS, de impostos, de direito do consumidor etc.). 
De fato, a comuníssima pluralidade de temas recursais impede que no âmbito do Tribunal Superior do Trabalho se faça a seleção de processos/casos padrão, com sobrestamento no próprio Tribunal ou na instância a quo, com posterior julgamento único por órgão majoritário e, não, Turma, possibilitada, depois, retratação da origem e, caso não ocorrida, reclamação a ser decidida monocraticamente.

Inegavelmente, também, o modelo recursal trabalhista está exaurido e isso se reflete no último grau de jurisdição trabalhista, sendo certo que o TST haveria de julgar mais teses do que casos singulares, sendo, inegavelmente, esta a função das Cortes de Cúpula, tal como tem insistido Ives Gandra da Silva Martins Filho, ${ }^{442}$ o que, todavia, já disse no capítulo anterior, há de ser visto cum granno salis, considerando-se as sérias objeções e informações que prestou José Guilherme Berman, ao se referir à tendência atual do papel das Cortes Constitucionais Européias na defesa das garantias dos direitos fundamentais dos cidadãos. $^{443}$

E, repita-se, o Tribunal Superior do Trabalho não está na cúpula do Judiciário Nacional, não tendo as funções do Supremo Tribunal Federal.

Embora não explícita na Carta Política, a história e a ininterrupta legislação federal evidenciam que a função primordial do TST (assim como a do TSE e a do STM) é definir o sentido e alcance da legislação trabalhista federal e, por isso, unificar a respectiva jurisprudência.

O modelo de transcendência do recurso de revista sugerido no voto vencido, que haveria de ser analisado em seu aspecto global, como é feito pelo Juiz no primeiro grau de jurisdição, ao propor a conciliação, dificilmente lograria êxito no TST porque as verdadeiras partes interessadas não estão presentes (às vezes nem os advogados); bem ou mal, dois graus de jurisdição já definiram a situação jurídica daquilo que é devido ou indevido e, sob o aspecto econômico e social, é extremamente subjetivo, fluido e perigoso o raciocínio do perde, ganha ou compensa.

\footnotetext{
${ }^{442}$ Esta função primordial do Tribunal Superior do Trabalho tem sido ressaltada pelo Ministro Ives Gandra da Silva Martins Filho, o que se pode constatar, por exemplo, nos seguinte artigos: $O$ critério de transcendência do recurso de revista na Justiça do Trabalho: constitucionalidade da MP no 2226/0, cit., p. 380-415 e $O$ critério de transcendência no recurso de revista. Disponível em: $<$ http://www.planalto.gov.br/ccivil_03/revista/Rev_20/artigos/IvesGandra_rev20.htm>. Acesso em: 23 out. 2010.

${ }^{443}$ BERMAN, José Guilherme, op. cit., p. 131.
} 
Noutro ponto tem razão o Ministro Ives Gandra da Silva Martins Filho: a qualidade dos julgamentos, o aprimoramento das teses, a resposta pronta e segura da Corte para os problemas mais candentes e numerosos, assim como a celeridade hão de ser buscados, não sendo razoável subsistir um sistema tal que, simulando Justiça, proceda a milhares de julgamentos em uma sessão, como se fosse a coisa mais normal do mundo.

Também há de ficar bem delineada a questão da delegação de jurisdição, em princípio totalmente vedada, mormente de maneira camuflada.

Em sã consciência, mormente no Supremo Tribunal Federal e nos Tribunais Superiores, é inimaginável que os Julgadores ali atuantes com a máxima responsabilidade, possam ter plena ciência de todo o conteúdo dos processos que lhes são submetidos, daí por que tem pertinência a invocação da sistemática aplicada na Suprema Corte dos Estados Unidos, na qual os Justices se valem de assessores (temporários), altamente experientes e gabaritados, os chamados judicial clerks, que ficam diretamente envolvidos na triagem do certiorari, tal como explicou Adhemar Ferreira Maciel, já anteriormente citado. ${ }^{444}$

Não resta a menor dúvida de que a implantação da transcendência significa uma ruptura drástica em face do modelo tradicional (e, diga-se, centenário) de preservação da unidade da aplicação e interpretação da legislação nacional, feito através do recurso de revista, em grau extraordinário de jurisdição, ainda mais considerando-se que nos dois primeiros graus anteriores não há qualquer critério discricionário de escolha de casos para julgamento.

A discricionariedade que envolve o critério da transcendência é o que mais assusta a sociedade, disse-o Maria Cristina Mattioli ${ }^{445}$, mas como

\begin{abstract}
se trata de uma ato de decisão e como toda decisão é fruto de um processo de escolha, não fica difícil concluir que a transcendência está afeta a um ato político. Político porque estaremos confiando aos Ministros dessa Corte Trabalhista dizer o que é transcendente para a sociedade. Nesse sentido, a decisão jurídica ocorrerá em situações onde não existe simetria entre alternativas e consequiências, daí porque a decisão funciona como opção pela alternativa que satisfaça requisitos mínimos de aceitabilidade (relevância política, econômica e social). Esta escolha se fará, necessariamente, em função de elementos reais de valor $\mathrm{e}$, por isso, em certo sentido, externos às normas legais. Todavia, não se
\end{abstract}

\footnotetext{
${ }^{444}$ MACIEL, Adhemar Ferreira. op. cit., p. 8-9. Vide notas de rodapé 334 e 335.

${ }^{445}$ MATIOLLI, Maria Cristina. Transcendência: uma resposta política à morosidade da Justiça. Revista do

Tribunal Superior do Trabalho, Porto Alegre, v. 67, n. 4, p. 129-141, out./dez. 2001.
} 
poderá dizer que esta transcendência é absoluta, na medida em que o Pode Judiciário, deve observar aos fins sociais e ao bem comum, nos termos do art. $5^{\circ}$ da Lei de Introdução ao Código Civil. Este, pois, um excelente mecanismo de controle e ao mesmo tempo um freio para a análise de conceito tão indeterminado. O rompimento com esta concepção tradicional e limitada do ato de decidir é o ponto de partida para se permitir uma concepção mais flexível e aberta deste ato jurisdicional, trazendo-lhe um significado transcendental. Esta forma de pensar - holisticamente - é uma fase adiantada da evolução de posicionamentos críticos do direito na história americana.

E conclui:

Evidentemente, a aceitação da transcendência como critério que rompe o padrão tradicional do ato de decidir, compreende uma mudança radical. Não se trata, simplesmente, de adotar um critério com o objetivo de melhorar a instituição ou diagnosticar seus erros e desacertos. Trata-se, isto sim, de assumir uma postura nova e de se ter coragem de enfrentar os mitos e criar um novo paradigma, em que o conflito é visto e tratado globalmente, no seu ser, no seu protagonismo, em que as soluções a serem encontradas tenham em conta não apenas um átomo de vida, mas a própria existência da sociedade.

Nada obstante estas asserções, a quebra da vigente estrutura jurídica recursal, de tradição legal, pela qual fixam-se as hipóteses de cabimento, com pouca flexibilidade para o Juiz, e na qual a jurisprudência vai se construindo desde a primeira manifestação dos mais variados e distantes magistrados, pode causar grande celeuma na medida em que surge só no último estágio de julgamento, deixando-se de lado o raciocínio indutivo ou dedutivo e, agora, surgindo o raciocínio tópico ou de problematização, com vistas à solução de casos escolhidos.

Por isso que Gerson Lacerda Pistori fez restrições à transcendência, advogando que seria "menos traumático, ou polêmico, mais adequado à tradição jurídica brasileira, parte de nossa cultura"446 aprimorar o uso das súmulas e das orientações jurisprudenciais na função de filtro recursal, quiçá eliminando as hipóteses de divergência decorrentes de aplicação de lei estadual, acordo, convenção coletiva, regulamento de empresa ou de sentença normativa que ultrapasse a aplicação territorial de dois tribunais regionais (letra "b" do art. 896 da CLT), o que, todavia enfrentaria, de cara, um problema, pois haveria de

\footnotetext{
${ }^{446}$ PISTORI, Gerson Lacerda. Recurso de revista: transcendência ou imanência. In. Direito do trabalho: reflexões críticas: estudos em homenagem à Dra. Moema Baptista. São Paulo: LTr, 2003.
} 
existir uma solução específica para o Estado de São Paulo, dividido que está em dois Tribunais Regionais.

Analisados, portanto, os prós e os contra, o anteprojeto de lei apresentado pela última Comissão da Transcendência caminha nessa trilha de uma reforma mais abrangente dos recursos trabalhistas em geral.

Principiando pelo recurso de embargos (art. 894 da CLT), propugna-se dar maior prevalência para a jurisprudência sumulada ou iterativa e notória, impondo multa ao recorrente de má-fé que insista em desconhecê-la ou contrariá-la, seja no próprio recurso de embargos, seja no subsequente agravo que vier a ser oferecido no caso de trancamento pelo Ministro Relator. Quando o recurso for inviável por falta de pressuposto extrínseco, passa a ser exigido o depósito da multa para recursos subsequentes $\left(\S 4^{\circ}\right)$, o que há muito é praticado para os embargos de declaração abusivos.

Já o recurso de revista (art. 896 da CLT) mereceu aperfeiçoamentos dignos de nota no anteprojeto de lei, particularmente incorporando as diretrizes da (em certo momento controversa) Instrução Normativa n. 23 do TST, de 5 de agosto de 2003 (que recomenda como haveriam de ser feitas as petições de recurso de revista) e da Súmula 297/TST, sugerindo, por exemplo, que a parte deve indicar $\left(\S 1^{\circ}\right)$ os trechos do acórdão recorrido que demonstram o prequestionamento da controvérsia e, também, apontar, "de forma explícita e fundamentada, a contrariedade a dispositivo de lei, súmula ou orientação jurisprudencial do TST que conflite com a decisão regional.”

$O$ anteprojeto de lei também toca num ponto muito sensível, já antes referido, que é o da necessidade de os relutantes Tribunais Regionais do Trabalho procedam à uniformização de sua jurisprudência, aplicando, no que couber, a sistemática dos recursos repetitivos prevista no $\mathrm{CPC}$, o que há muito já preconizava o art. 14 da Lei 7701/88 e passou a ser exigido pelo $§ 3^{\circ}$ do art. 896 da CLT (redação da lei 9756/98: “os Tribunais Regionais do Trabalho procederão, obrigatoriamente, à uniformização de sua jurisprudência"...)

Aqui, talvez, devesse ser inserida uma proposta legislativa para conciliar a existência de dois tribunais regionais do trabalho no Estado de São Paulo, sendo comum haver dissenso interpretativo de legislação estadual ou de normas coletivas de aplicação nas duas jurisdições, criando-se um incidente de uniformização especial entre a $2^{\mathrm{a}}$ e a $15^{\mathrm{a}}$ 
Regiões, inclusive por meios eletrônicos modernos, como acontece no Supremo ao ser feita a proposta de repercussão geral por um dos Ministros.

Ainda na questão da uniformização jurisprudencial interna, é contundente (e espera-se eficaz) a imposição pelo Ministro Relator do retorno dos autos ao Regional $\left(\S 4^{\circ}\right)$ ou a determinação nesse sentido a ser feita, desde logo, por seu Presidente, antes da remessa dos autos ao TST $\left(\S 5^{\circ}\right)$, de sorte que não haverá mais escapatória para a falta de cumprimento dessa já vetusta obrigação dos Tribunais Regionais.

Quando a revista vier por dissenso, incumbirá ao recorrente produzir a prova da divergência, agora incorporando-se na lei as diretrizes da Súmula 337/TST, inclusive no tema das citações ou invocações de julgados extraídos da internet.

Tal como no recurso de embargos, o Ministro Relator dispõe de poderes para denegar, monocraticamente, a revista e o agravo de instrumento contrários à jurisprudência iterativa, notória e atual do TST, bem como às súmulas e às orientações jurisprudenciais, inclusive súmulas do STF, vinculantes ou, não, e, evidentemente, nos casos de ausência dos pressupostos extrínsecos.

Se a parte oferecer agravo manifestamente inadmissível ou infundado, haverá multa entre um e dez por cento do valor da causa corrigido, condicionado o oferecimento de recurso subsequente ao respectivo depósito. Os valores das multas sempre haverão de ser líquidos.

Já o art. 896-C propõe a aplicação ao recurso de revista, no que couber, as normas do CPC que regem o julgamento dos recursos extraordinários e especial repetitivos, o que só a prática poderá confirmar a boa intenção.

Os embargos de declaração do art. 897-A da CLT também não escapam de aperfeiçoamentos, mormente no que se refere à imposição de multa no caso de protelação, tendo havido parcimônia no percentual, que ficou limitado a cinco por cento. Também foi previsto o depósito dessa multa e de outra de até dez por cento, em caso de embargos sucessivos a anteriores que já foram considerados protelatórios.

Houve, porém, uma pecadilho no $\S 3^{\circ}$ do art. 896-A da CLT, pois não só os embargos intempestivos deixam de interromper o prazo para a interposição de outros recursos posteriores: também o apelo inexistente, ou seja, aquele que é apresentado sem 
mandato há de sofrer a mesma cominação, sob pena de consagrarem-se chicanas e simulações.

Nesse sentido, por exemplo, o entendimento da SBDI-1 do TST, como se vê no processo E-ED-RR - 66074/2002-900-02-00 PUBLICAÇÃO: DEJT - 03/10/2008, de Relatoria do Ministro Horácio Senna Pires, acolhido por unanimidade, em cuja fundamentação há citação de vários precedentes da própria seção, não se limitando à questão da intempestividade dos declaratórios como fator determinante da não interrupção do prazo dos apelos subsequentes. ${ }^{447}$

Também peca o anteprojeto ao não definir melhor a questão do efeito devolutivo dos recursos e a da execução provisória (art. 899, caput, da CLT), mantendo o marco final desta na penhora.

Aqui poderiam ter sido incorporados as mais recentes disposições do CPC sobre a matéria, ou, pelo menos, que se avançasse um pouco mais além da penhora, ou seja, permitidas a penhora em dinheiro (o item III da Súmula 417/TST é irreal, pois, muitas vezes logra-se penhorar dinheiro do devedor na execução provisória, devolvem-se porque contrariariam (?) o art. 620 do CPC, mas, na execução definitiva, nada mais se encontra), autorizada a remoção do bem (isto porque o depositário infiel, hoje em dia, não tem mais sobre si a ameaça da prisão civil e desvirtua o encargo), possibilitada a realização de praça ou leilão, apenas ficando suspensa a entrega ao credor, seja do bem, seja do dinheiro.

Oportuno, também, o esclarecimento em torno do mandato tácito, devendo a parte indicar "a ata da audiência que o configura", tal como vem proposto no $\S 7^{\circ}$ do art. 899 da CLT.

O anteprojeto de lei também poderia ter avançado na questão do depósito recursal, passando a exigi-los também nas execuções, pois se trata de pressuposto de admissibilidade dos apelos trabalhistas em si mesmos, o que é diferente da garantia da execução, que se dá com a penhora.

Ao menos que houvesse o depósito na hipótese de recurso de revista ou de recurso extraordinário, o que, inclusive, não discreparia de centenária tradição lusitana, como

\footnotetext{
${ }^{447}$ Acórdão extraído do sítio de jurisprudência do TRIBUNAL SUPERIOR DO TRABALHO. Disponível em: <http://ext02.tst.jus.br/pls/ap01/ap_red100.resumo?num_int=89539\&ano_int=2002\&qtd_acesso=1266137>. Acesso em: 23 out. 2010.
} 
vimos, já preocupada com a efetividade da justiça, razão maior da instituição desse requisito.

No mínimo, a parte incontroversa da execução haveria de ser depositada em dinheiro, ficando indisponível até o julgamento do agravo de petição ou seria permitida apresentação de fiança bancária. Em situações de empresa familiar ou de micro empresário, o Juiz da execução poderia flexibilizar o depósito da execução.

O anteprojeto não toca no recurso ordinário, todavia.

E, sem dúvida, seria uma boa oportunidade para ampliar os processos de alçada, irrealisticamente, desde a década de 1970, fixados em dois salários mínimos, o que poderia ser ampliado para 5, pelo menos. Também o teto do procedimento sumaríssimo poderia ser ampliado até 60 salários mínimos, o que, aliás, corresponde àquele adotado nos Juizados Federais, inclusive servindo de parâmetro federal para a inexigibilidade de precatórios (arts. $3^{\circ}$ e $17, \S 1^{\circ}$, da Lei 10.259/01).

Finalmente, o anteprojeto consagra em lei o julgamento de reclamações (art. $2^{\circ}$ ) para a preservação da competência e da autoridade das decisões proferidas pelo TST, o que mais efeitos surtirá, caso o resto da Reforma do Judiciário, ainda em trâmite no Congresso Nacional, venha a consagrar as súmulas vinculantes dos Tribunais Superiores ou as impeditivas de recurso.

A maior novidade do anteprojeto de lei ficou reservada para o art. $3^{\circ}$ : "quando o recurso tempestivo for inadmissível por defeito formal que não se repute grave, o Tribunal Superior do Trabalho poderá desconsiderar o vício e julgar o mérito de casos repetitivos ou sempre que a decisão da questão de mérito contribua (sic) para o aperfeiçoamento do sistema jurídico".

A proposta é ousada porque permite que o Tribunal releve defeito formal do recurso, o que representa mudança de paradigma daquilo que até hoje vinha sendo adotado pelo TST.

Basta lembrar aquela jurisprudência (por alguns chamada defensiva) que se consolidou no TST para (inegavelmente) desvencilhar-se de grande número de processos, como, por exemplo, a OJ. 140 (diferença ínfima, de centavos, no pagamento das custas ou do depósito recursal, não impede deserção); a OJT 21 (que não reconhece validade de 
certidão do Regional dizendo que o instrumento do agravo havia sido feito em conformidade com a IN 06/96 do TST); a OJ 287 (exigência de autenticação de frente e verso do documento); a OJ 373 (sobre mandato outorgado por pessoa jurídica, cujo rigor foi amenizado com a nova redação ocorrida em 23/11/2010); a OJ 110 (não reconhecendo mandato nos autos principais, quando, todavia, no agravo apensado ele está comprovado), a Súmula 415 (que exige autenticação de documento essencial no mandado de segurança, em pleno vigor, malgrado a nova redação dada ao art. 830 da CLT, feita pela Lei 11925/09).

A propósito, rememore-se das já canceladas Súmula 270 (que exigia reconhecimento de firma na procuração) e a famosa OJ 320 (sobre o protocolo regional integrado, que não era aceito pelo TST).

Voltando ao anteprojeto de lei, se for feita a escolha de um caso representativo de processo repetitivo, que a triagem seja bem feita, ou seja, que se encontre um exemplar no qual estejam preenchidos todos os pressupostos extrínsecos, intrínsecos e específicos. E o mesmo vale para aquele caso em que a decisão de mérito contribua para o aperfeiçoamento do sistema jurídico. Aliás, nesse particular, está sendo adotado o sistema recursal alemão, antes mencionado, adotando-se um critério de relevância ou transcendência jurídica (grundsätzlichen bedeutung)

Em razão de tudo o quanto acima foi dito, a criação de barreira de contenção de recursos, propósito mais evidente que se extrai da transcendência (e que foi placitado no voto da ADI 2527 pela Ministra Ellen Gracie e pela maioria que a acompanhou), não pode constituir, apenas, uma solução para o fardo dos julgadores ${ }^{448}$, mas deve servir ao insubstituível propósito de unificação da aplicação e de interpretação do direito do trabalho, razão de ser do recurso de revista, assim como a busca de verdadeira justiça substancial. $^{449}$

\footnotetext{
${ }^{448}$ Confira-se o artigo de Wagner D. Giglio (O requisito prévio da transcendência, cit., p. 16) que a criticou como meio de diminuição dos processos a cargo dos Ministros do TST, nisso existindo "um desvio axiológico, pois a reforma legislativa, em lugar de considerar o direito e os interesses dos jurisdicionados, aprimorando a administração da justiça, cuidou de resolver problema dos juízes, de superar as dificuldades de atuação do Tribunal Superior do Trabalho." Este mesmo autor viu também possibilidade desse requisito contribuir para a insegurança jurídica.

${ }^{449}$ Tal como a visão histórica revelou, aquilo que era excepcional tornou-se ordinário com o passar do tempo (appelatio, supplicatio, retractatio, sopricação, suplicação, revista de graça, agravo ordinário, revista de graça especialíssima, revista de justiça). Não se ignora a natureza extraordinária do recurso de revista, vale dizer, excepcional e condicionada, na exata dição de Alcides de Mendonça Lima, autor de antiga e respeitada obra Recursos Trabalhistas, citado por SILVA, Carlos Alberto Barata. Recurso de revista na justiça do trabalho. São Paulo: LTr, 1972. p. 7.
} 
Toda a trajetória desse apelo de natureza extraordinária vai em busca da construção de certeza e de segurança nas relações jurídicas entre trabalhadores e empregadores, que não pode ficar à mercê de manifestações isoladas e, às vezes, distorcidas, ainda que provenientes de ilustres julgadores ou doutrinadores (freio ao arbítrio e busca de mais justiça nas decisões colegiadas, nota comum dos recursos, em geral).

Nisso tudo há de se considerar, também, importante detalhe da realidade dos processos que tramitam na Justiça Comum e na do Trabalho: na primeira, via de regra, discutem-se direitos individuais, que não ultrapassam a esfera de seus respectivos interesses pessoais, o que justificaria, por exceção, a seleção de processos mais relevantes e com repercussão geral.

No processo do trabalho, todavia, embora prevaleçam os dissídios individuais, na sua quase totalidade estão em jogo interesses de grupo de trabalhadores ou de categorias inteiras, como são ilustrativos os casos, por exemplo, da extinção ou, não, do contrato de trabalho pela aposentadoria, o direito ao FGTS nos contratos nulos, a responsabilidade subsidiária da pessoa de direito público nos casos de terceirização, a questão da hora noturna reduzida nos turnos ininterruptos, a interpretação da confiança bancária ou do trabalho externo dos motoristas etc., sem falar nos casos em que o sindicato atua como substituto processual nas ações de cumprimento (art. 872 da CLT) ou nas que busca a caracterização de insalubridade ou de periculosidade ( $§ 2^{\circ}$ do art. 195 da CLT)

Não é atoa que as Súmulas e os seus embriões, as Orientações Jurisprudenciais (inclusive - e até mais - as orientações chamadas transitórias) são fruto de inúmeros casos individuais que têm repercussão categorial ou grupal no âmbito das relações de trabalho, por exemplo, envolvendo grandes empresas nacionais, como Banco do Brasil, Petrobrás, Conab, Usiminas, Banrisul, BNCC, CSN, ENERGIPE, CEEE, INTERBRAS, SPTRANS etc. 


\section{CONCLUSÕES}

A História do Direito revela que é imprescindível para a afirmação, consolidação e manutenção do poder que haja contínua e preponderante uniformidade de aplicação da lei e de sua interpretação, com vistas a atingir segurança e estabilidade nas relações sociais e, ainda, lograr um desejado grau Justiça nas decisões.

Para atingir esse desiderato, ao longo dos tempos, dentro da tradição romana e ibérica, dentro da evolução da recorribilidade, a parte prejudicada passou a dispor de um recurso excepcional, exatamente porque dirigido ao Imperador ou ao Rei, e desde que se apresentassem situações de tal importância que ultrapassassem o interesse imediato das pessoas envolvidas, como nos casos de manifesta violação de lei, desconformidade com entendimento anterior já consagrado (jurisprudência) e na ocorrência de vícios processuais graves (falta de citação e suborno dos julgadores).

Exemplo desse tipo de recurso era a supplicatio romana, que deu origem à sopricação ou suplicação, depois denominada agravo ordinário, revista de graça especial e revista de graça especialíssima, posteriormente, recurso de revista. O Tribunal competente para apreciar esse apelo era aquele que funcionava junto ao Imperador ou Rei (Curia Regia), através de dignitários que agiram em seu nome, paulatinamente especializando-se nesse mister judicial e passando a gozar dalguma autonomia, constituindo, em Portugal, a Casa de Justiça e, depois, Casa da Suplicação (por metonímia, tomou-se o nome dos recursos que estava incumbida de julgar); esta denominação chegou ao Brasil Colônia e, depois da Independência, a mais elevada Corte do País passa-se a chamar Supremo Tribunal de Justiça e, com a República, Supremo Tribunal Federal.

Os recursos de natureza extraordinária têm essa origem comum romana e ibérica e, com o passar dos anos, subdividiram-se de acordo com a competências que se distribuíram constitucionalmente aos vários órgãos judicantes, daí chegando-se ao recurso de revista no âmbito da Justiça do Trabalho.

A crise por que passa a Jurisdição em geral, primordialmente porque não consegue solucionar todas as lides que lhe são apresentadas de forma justa, segura, coerente e dentro de razoável e útil espaço de tempo, gera descrédito do Judiciário e do próprio Estado, daí 
por que hão de ser buscadas formas que solucionem os conflitos de massa com novas técnicas, que não se originem, exclusivamente, no já tradicional modo de solução dos dissídios individuais, o que há se influir nos procedimentos recursais e, particularmente, na atuação dos Tribunais Regionais do Trabalho e na do Tribunal Superior do Trabalho.

Na Corte Suprema dos Estados Unidos, os Juízes selecionam os casos que irão julgar através do petition for writ of certiorari, tratando-se da mais conhecida e discricionária técnica de filtragem de processos, que deitou influência em vários países, não estando, porém, imune a críticas atuais sobre o excessivo papel político que adquirem as decisões dos Justices. Na Europa também se encontram exemplos de escolha dos casos que merecerão análise por parte das Cortes Constitucionais, havendo, todavia, alguma reabertura de acesso generalizado dos cidadãos a esses tribunais, em nome da preservação dos direitos fundamentais.

No Brasil, a arguição de relevância, criada e autorizada por Emenda Constitucional à Carta de 1969, com regulamentação a cargo do Supremo Tribunal Federal, desempenhou esse papel de triagem das causas mais importantes que haveriam se merecer sua análise, tendo, no entanto, funcionado mais como forma de inclusão do que de exclusão, alargando, portanto, a admissibilidade do recurso extraordinário, para além das hipóteses definidas na Constituição.

A transcendência do recurso de revista representa a primeira tentativa brasileira no século XXI com vistas à triagem de processos para julgamento no âmbito de Tribunal Superior do Trabalho. Ela notoriamente valeu-se da experiência norte-americana e da argentina, assim como de países europeus e, ainda, tem raízes na antiga arguição de relevância do Supremo Tribunal Federal.

Uma vez que o pressuposto recursal específico da transcendência veio a ser criado por Medida Provisória, que confiou a disciplina de seu processamento ao Regimento Interno do Tribunal Superior do Trabalho, o que não aconteceu, faz quase 10 anos completos, esse requisito não surtiu nenhum efeito prático para os inúmeros recursos de revista interpostos desde setembro de 2001. Resultou, todavia, um fruto inesperado: permitiu fosse repensado e reafirmado o papel do Tribunal Superior do Trabalho (essencial para a aplicação da lei e sua interpretação uniforme no país). Também possibilitou rediscutir os recursos de índole extraordinária, em geral, abrindo as portas para a 
introdução da repercussão geral da questão constitucional, como requisito do recurso extraordinário.

A repercussão geral, regulamentada por lei para a admissão do recurso extraordinário, veio autorizada no bojo da Reforma do Judiciário, cristalizada na Emenda Constitucional 45/04, que, também, reafirmou e consagrou o efeito vinculante dos julgamentos do Supremo Tribunal Federal nas ações diretas de inconstitucionalidade e nas ações declaratórias de constitucionalidade. Permitiu, ainda, que a Corte Suprema edite Súmulas Vinculantes, o que demonstra esforço para se atingir o pleno respeito e eficácia das suas decisões, o que, todavia, não se espraiou para os Tribunais Superiores da Federação, particularmente o STJ e TST, ambos às voltas com número excessivo de recursos, com todas as maléficas consequências aos jurisdicionados advindas desse fato.

A redescoberta da aplicação do efeito vinculante dos julgamentos reiterados e consolidados pela última instância da Jurisdição revela-se técnica exitosa para a solução de causas idênticas. E, guardadas as devidas proporções e feitas as adaptações ao regime constitucional vigente, não é possível ignorar a centenária experiência lusitana dos Assentos da Casa da Suplicação, e, ainda, a brasileira dos Prejulgados do Tribunal Superior do Trabalho, previstos no antigo art. 902 da CLT, na redação que lhe deu o Decreto-lei 8737, de 19 de janeiro de 1946, cujo $\S 1^{\circ}$ dizia que "os Tribunais Regionais do Trabalho, as Juntas de Conciliação e Julgamento e os Juízes de Direito investidos da jurisdição da Justiça do Trabalho ficarão obrigados a respeitá-lo", malgrado, posteriormente, este artigo tenha sido reputado inconstitucional, assim como em Portugal tenham sido abolidos os assentos.

Há sérias dúvidas sobre a constitucionalidade da Medida Provisória 2226/01, pois, seguindo jurisprudência firme do Supremo Tribunal Federal, consolidada desde 1999, as medidas provisórias não poderiam veicular tema processual, como foi o caso do requisito específico da transcendência do recurso de revista. De outro lado, a Emenda Constitucional 32/01, que proibiu edição de medida provisória sobre matéria processual, amoldando-se à jurisprudência da Suprema Corte, criou aberração maior ao permitir que a medida provisória da transcendência ficasse valendo por tempo indeterminado, o que contraria a essência desse tipo normativo, editado sob condição, apenas com força de lei e que não pode deixar de ser apreciado pelo Poder Legislativo, implicando hipertrofia antidemocrática do Poder Executivo. 
A transcendência econômica, política, social e jurídica, erigido como pressuposto específico do recurso de revista, de dificílima conceituação, haverá de se encaixar dentro dos propósitos do devido processo legal, formal e substancial. No particular, há coincidência com os objetivos mais conhecidos do processo do trabalho, comprometido com a celeridade, a adequação, a isonomia de tratamento das partes, a simplicidade, a índole protetiva. $\mathrm{O}$ processo do trabalho não pode deixar de ser uma ferramenta de busca da verdade real e de concretização dos direitos sociais, indissociáveis da pessoa do trabalhador, constitucionalmente protegido sob todos os aspectos de sua condição humana e respectiva dignidade, vale dizer, credor da efetivação dos direitos e garantias fundamentais a ele inerentes.

Nesse quadro, a materialização do pressuposto da transcendência do recurso de revista encontra sérios obstáculos concernentes à necessidade e à utilidade, inclusive de ordem prática.

A sucinta análise da antiga arguição de relevância, confrontada com a repercussão geral e com o sistema dos processos repetitivos, está a evidenciar a enorme gama de detalhes que faltou ser abordada na criação e implementação da transcendência do recurso de revista, cujo processamento não poderia ter ficado ao exclusivo descortino Tribunal Superior do Trabalho, sendo imprescindível a atuação do Parlamento.

Muito do descrédito que se atribui à criação da transcendência reside na quebra do padrão constitucional e legislativo que sempre foi adotado no trato de temas processuais, em face da necessária observância do devido processo legal. Difícil aceitar delegação de competência de modo a que a definição de pontos essenciais do recurso fique atribuída ao próprio órgão judicante. Uma mudança tão drástica na sistemática recursal trabalhista, haveria de sobrevir de maneira semelhante àquela que se deu com a repercussão geral, ou seja, com prévia autorização constitucional, ou, dadas as peculiaridades da Justiça do Trabalho, que decorresse de processo legislativo normal. E, afinal, que se guarde similitude de tratamento com o Superior Tribunal de Justiça, em idêntica posição hierárquica, no quadro constitucional do Poder Judiciário, que, até agora, não tem critério de escolha de recursos, mas, apenas, técnica de seleção ou modus operandi recursal peculiar.

A Comissão que o Tribunal Superior do Trabalho formou para a regulamentação da transcendência, cônscia de suas responsabilidades e não vendo condições práticas e 
jurídicas para disciplinar esse pressuposto, oferece anteprojeto de lei que descarta a transcendência, mas oferece outras alternativas para a melhoria do recurso de revista e, também, de outros apelos peculiares ao processo do trabalho. Merece destaque essa iniciativa no ponto que exige dos Tribunais Regionais a uniformização da respectiva jurisprudência interna.

Conquanto não tenha havido possibilidade e intenção de dar maior profundidade a todos os temas abordados, mas tentativa de costura dos vários ângulos pelos quais se pode ver o fenômeno recursal trabalhista e o recurso de revista, aproveita-se este derradeiro momento de conclusões para sugerirem-se alterações adicionais àquelas já delineadas no anteprojeto de lei da Comissão da Transcendência, além daquelas que já foram espargidas no próprio texto deste estudo.

Com efeito, seria o caso de se aproveitar o ensejo do anteprojeto de lei para, de vez, consagrar no âmbito do processo do trabalho o ônus do vencido pelo pagamento de honorários advocatícios, quiçá em percentual menor do que aquele previsto no $\S 3^{\circ}$ do art. 20 do CPC, não excluída, por certo, a gratuidade da Justiça. A experiência demonstra (infelizmente) grande irresponsabilidade no exercício do direito de ação e, ipso facto, na recorribilidade inconseqüente, pois não há qualquer prejuízo para o litigante desleal ou para o procurador que o defende, que também finge ignorar um padrão ético profissional.

Acrescente-se, também, proposta de ampliação o teto do dissídio de alçada, seja para 10 salários mínimos, seja para 5, tal como propôs, em 1999, o então Deputado Federal Jacques Wagner (PL 168/1999, mencionado neste trabalho). Paralelamente, que o teto do procedimento sumaríssimo atinja o patamar de 60 salários mínimos, em sintonia com o que estabelecido para os Juizados Federais, inclusive porque é o mesmo padrão de inexigibilidade de expedição de precatório. Na mesma linha de raciocínio, que os depósitos recursais voltem a ter parâmetro no salário mínimo, fixado por lei, afastando-se a prática de se aguardar a atualização por ato da Presidência do TST.

Outra providência legal seria modificar, completamente, o tratamento dos juros moratórios do processo trabalhista, unificando-os pela incidência do art. 406 do Código Civil, ante a irrisória compensação hoje decorrente dos índices da caderneta de poupança, verdadeiro estímulo para o inadimplemento das obrigações impostas na decisão judicial. 
A par destas providências que dependem de lei, outras há que o Tribunal Superior do Trabalho poderia implementar, desde logo, por exemplo, ampliando (criteriosamente, por certo) o número de Súmulas, elevando a esse nível já vetustas e sedimentadas Orientações Jurisprudenciais, o que obstaria interposição de recursos desnecessários ou impediria protelações. E, porque não ultimada a Reforma do Judiciário, que o Tribunal Superior do Trabalho atue com seu prestígio político e institucional para a retomada (pelo menos) da discussão sobre a implantação das Súmulas Vinculantes ou Impeditivas no âmbito da Justiça do Trabalho.

Todas estas conclusões e propostas, mais práticas e eficientes do que a transcendência, inserem-se na linha de idéias visando adequar aos novos tempos os recursos trabalhistas, em geral, e o de revista, em especial, pois não podem ser banalizados os julgamentos do Tribunal Superior do Trabalho, incumbido de preservar a unidade de aplicação e de interpretação da legislação trabalhista e da questão constitucional correlata.

A previsibilidade e a regularidade das relações de trabalho (não a sua imutabilidade) vão ao encontro dos fundamentos do Estado Democrático de Direito, particularmente aqueles de tratam da cidadania, da dignidade da pessoa humana e dos valores sociais do trabalho e da livre iniciativa (art. $1^{\circ}$, II, III e IV, da Constituição Federal). A unidade de aplicação do direito é essencial para a busca da isonomia entre os cidadãos trabalhadores, seus grupos e categorias, porquanto, geralmente, ela ocorre a partir dos centros de mão de obra mais evoluídos para os menos desenvolvidos e mais distantes.

A uniformidade de aplicação e de entendimento da lei e das normas do trabalho se espalha, concita à negociação e à solução extrajudicial de possíveis conflitos, gera harmonia, cria estabilidade e segurança (social e jurídica), e, mais do que isso, empurra e impede o arbítrio particular ou estatal.

Com tudo isso, não se foge do rumo norte traçado no caput do art. $7^{\circ}$ da Carta Política, pois se busca a melhoria da condição social do trabalhador e, ainda, adequa-se aos princípios que norteiam a atividade econômica, mormente a busca do pleno emprego (art. 170,VIII, da CF) e aos objetivos da ordem social (art. 193 da CF). 


\section{REFERÊNCIAS BIBLIOGRÁFICAS}

ALVIM NETO, José Manoel Arruda. A arguição de relevância no recurso extraordinário. São Paulo: Ed. Revista dos Tribunais, 1988.

ARAUJO, Luiz Alberto David; NUNES JÚNIOR, Vidal Serrano. Curso de direito constitucional. São Paulo: Saraiva, 1998.

ASSIS, Machado de. Obras completas. Rio de Janeiro: Ed. Nova Aguilar, 1992.

AZEVEDO, Luiz Carlos de. Introdução à história do direito. São Paulo: Ed. Revista dos Tribunais, 2005.

BAPTISTA, Newton Doreste. Da arguição de relevância no recurso extraordinário. Rio de Janeiro: Forense, 1976.

BARBOSA MOREIRA, José Carlos. Comentários ao Código de Processo Civil. 4. ed. Rio de Janeiro: Forense, 1981. v. 4.

BATAlHA, Wilson de Souza Campos. Tratado de direito judiciário do trabalho. São Paulo: LTr, 1977.

BERMAN, José Guilherme. Repercussão geral no recurso extraordinário: origens e perspectivas. Curitiba: Juruá, 2009.

BRUGGER, Walter. Dicionário de filosofia. São Paulo: Ed. Herder, 1962.

CAETANO, Marcello. História do direito português, Lisboa: Editorial Verbo, 1985.

COMTE-SPONVILLE, André. Dicionário filosófico. Tradução de Eduardo Brandão. São Paulo: Martins Fontes, 2003.

COSTA, Mário Júlio de Almeida. História do direito português. Coimbra: Almedina, 1992.

COSTA, Moacyr Lobo da. A revogação da sentença. São Paulo: Ícone, 1995.

CRUZ E TUCCI, José Rogério. Anotações sobre a repercussão geral como pressuposto de admissibilidade do recurso extraordinário (Lei 11.418/2006). Revista de Processo, São Paulo, ano 32, n. 145, mar. 2007.

Jurisdição e poder. São Paulo: Saraiva, 1987. 
CRUZ E TUCCI, José Rogério. Perspectiva histórica do precedente judicial. 2003. Tese (Titular) - Faculdade de Direito da Universidade, São Paulo. São Paulo, 2003.

; AZEVEDO, Luiz Carlos de. Lições de história do processo civil canônico. São Paulo: Ed. Revista dos Tribunais, 2001.

Tribunais, 2009. . Lições de história do processo civil lusitano. São Paulo: Ed. Revista dos ; L Lições de história do processo civil romano. São Paulo: Ed. Revista dos Tribunais, 2001.

DANTAS, Ivo. Da repercussão geral como pressuposto específico e como filtro ou barreira de qualificação do recurso extraordinário. Disponível em: <http://jusvi.com/artigos/40811>. Acesso em: 22 nov. 2010.

DIDIER JR., Fredie. Curso de direito processual civil. 12. ed. Salvador: Jus Podium, 2010. v. 1.

DINIZ, José Janguiê Bezzera. Recursos no processo do trabalho. São Paulo: LTr. 2005.

DINIZ, Maria Helena. Compêndio de introdução à ciência do direito. 19. ed. São Paulo: Saraiva, 2008.

ENGISH, Karl. Introdução ao pensamento jurídico. 6. ed. Lisboa: Fundação Calouste Gulbenkian, 1988.

FERRAZ JR., Tercio Sampaio. Introdução ao estudo do direito. 3. ed. São Paulo: Atlas, 2001.

Introdução ao estudo do direito: técnica, decisão, dominação. 4. ed. São Paulo: Atlas, 2003.

FERREIRA, Luís Pinto. Princípios gerais do direito constitucional moderno. 6. ed. São Paulo: Saraiva, 1983. v. 1.

GIGLIO, Wagner D. Direito processual do trabalho. 14. ed. São Paulo: Saraiva, 2005. jan. 2002.

O requisito prévio da transcendência. Revista LTr, São Paulo, v. 66, n. 1, p. 16-18,

GONÇALVES, Elainy Morais. A transcendência dos motivos determinantes e a força normativa da Constituição. BDJur, Brasília, DF, 15 abr. 2008. Disponível em: <http://bdjur.stj.gov.br/dspace/handle/2011/16869>. Acesso em: 29 out. 2010.

GRANDE Dicionário Enciclopédico Verbo. Lisboa; São Paulo: Editorial Verbo, 1997. v. 3. 
GRECO FILHO. Vicente. Direito processual civil brasileiro. São Paulo: Saraiva, 1996.

HOUAISS, Antônio; VILlAR, Mauro de Salles. Dicionário Houaiss da língua portuguesa. Rio de Janeiro: Objetiva, 2001.

KELSEN, Hans. Teoria pura do direito. 6. ed. São Paulo: Martins Fontes, 1998.

LEITE, Carlos Henrique Bezerra. Curso de direito processual do trabalho. 8. ed. São Paulo: LTr, 2010.

LINDOSO, Alexandre Simões. Técnica dos recursos trabalhistas extraordinários. São Paulo: LTr, 2010.

MACIEL, Adhemar Ferreira. Restrição à admissibilidade de recursos na Suprema Corte dos Estados Unidos e no Supremo Tribunal Federal do Brasil. Revista de Informação Legislativa, Brasília, ano 43, n. 170, abr./jun. 2006.

MAGAlHÃES, Álvaro et al. Dicionário enciclopédico brasileiro. Porto Alegre: Editora Globo, 1954.

MALLET, Estêvão, Antecipação da tutela no processo do trabalho. São Paulo: LTr, 1999.

Celeridade da prestação jurisdicional e seleção das causas a serem julgadas pelos Tribunais Superiores. In: Direito e processo do trabalho em transformação. Rio de Janeiro: Elsevier, 2007.

Do recurso de revista no processo do trabalho. São Paulo: LTr, 1995.

Prática de direito do trabalho. São Paulo: LTr, 2008.

MARINONI, Luiz Guilherme. O filtro processual do STF. RT Informa, São Paulo, ano 9, ed. espec. n. 52, nov. 2007/abr. 2008.

MARTINS FILHO, Ives Gandra da Silva. O critério de transcendência no recurso de revista. Disponível em: <http://www.planalto.gov.br/ccivil_03/revista/Rev_20/artigos/IvesGandra_rev20.htm>. Acesso em: 23 out. 2010.

O critério de transcendência do recurso de revista na Justiça do Trabalho: constitucionalidade da MP $\mathrm{n}^{\circ}$ 2226/0. In: As vertentes do direito constitucional contemporâneo. Rio de Janeiro: América Jurídica, 2002.

MATIOLLI, Maria Cristina. Transcendência: uma resposta política à morosidade da Justiça. Revista do Tribunal Superior do Trabalho, Porto Alegre, v. 67, n. 4, p. 129-141, out./dez. 2001. 
MENDES, Gilmar Ferreira; COELHO, Inocêncio Mártires; BRANCO, Paulo Gustavo Gonet. Curso de direito constitucional. 3. ed. São Paulo: Saraiva, 2008.

MORAES, Alexandre de. Direito constitucional. 24. ed. São Paulo: Atlas, 2009.

NERY JUNIOR, Nelson. Princípios do processo na Constituição Federal. 9. ed. São Paulo: Ed. Revista dos Tribunais, 2009.

OLIVEIRA, Guilherme José Braz de. Repercussão geral das questões constitucionais e suas consequências para o julgamento do recurso extraordinário. 2009. Dissertação (Mestrado) - Faculdade de Direito, Universidade de São Paulo, 2009. 383p. Disponível em: $\quad<$ http://www.teses.usp.br/teses/disponiveis/2/2137/tde-16042010124802/publico/Guilherme_Jose_Braz_de_Oliveira_Dissertacao.pdf $>$ Acesso em: 20 out. 2010 .

ORDENAÇÕES Afonsinas. Lisboa: Ed. Fundação Calouste Gulbenkian, 1984. Livro 3.

ORDENAÇÕES Filipinas. Lisboa: Ed. Fundação Calouste Gulbenkian, 1985. Livro 3.

ORDENAÇÕES Manuelinas. Lisboa: Ed. Fundação Calouste Gulbenkian, 1984, Livro 1.

PISTORI, Gerson Lacerda. Recurso de revista: transcendência ou imanência. In. Direito do trabalho: reflexões críticas: estudos em homenagem à Dra. Moema Baptista. São Paulo: LTr, 2003.

REZENDE FILHO, Gabriel José Rodrigues de. Curso de direito processual civil. 5. ed., São Paulo: Saraiva, 1957.

RUSSOMANO, Mozart Victor. Comentários à Consolidação das Leis do Trabalho. 5. ed. Rio de Janeiro: José Konfino Editor, 1960. v. 5.

Direito processual do trabalho. São Paulo: LTr, 1977.

SANTOS, Moacyr Amaral. Primeiras linhas de direito processual civil. São Paulo: Saraiva, 1990.

SILVA, Antônio Álvares. O novo recurso de revista na justiça do trabalho. São Paulo: LTr, 1999.

SILVA, Carlos Alberto Barata. Recurso de revista na justiça do trabalho. São Paulo: LTr, 1972.

SILVA, De Plácido e. Vocabulário jurídico. Rio de Janeiro: Forense, 1963. . Vocabulário jurídico. 27. ed. Rio de Janeiro: Forense, 2007. 
SILVA, José Afonso da. Curso de direito constitucional positivo. 31. ed. São Pauyulo: Malheiros Ed., 2008.

SOUZA, José Pedro de Camargo Rodrigues de. Omissões. In: BOUCINHAS FILHO, Jorge Cavalcanti; PEREIRA, José Luciano de Castilho; FAVA, Marcos (Orgs.). O direito material e processual do trabalho dos novos tempos: estudos em Homenagem ao Professor Estêvão Mallet. São Paulo: LTr, 2009.p. 359-365.

TARDIF, Adolphe. La procédure civile et Ccriminelle aux XIII ème et XIV ème siècles ou procédure de transition. Paris: Alphonse Picard, 1885. Disponível em: http://gallica.bnf.fr/ark:/12148/bpt6k716934.r=Adolphe+Tardif.langPT. Acesso em: 25 out. 2010.

TEIXEIRA FILHO, Manoel Antonio. Sistema dos recursos trabalhistas. São Paulo: LTr, 1989.

TEMER, Michel. Elementos de direito constitucional. 22. ed. São Paulo: Malheiros Ed., 2007.

THEODORO JUNIOR, Humberto; NUNES, Dierle; BAHIA, Alexandre. Litigiosidade em massa e repercussão geral no recurso extraordinário. Revista de Processo, São Paulo, ano 34 , n. 177 , nov. 2009.

TOLEDO FILHO, Manoel Carlos. Fundamentos e perspectivas do processo trabalhista brasileiro. São Paulo: LTr, 2006.

TUCCI, Rogério Lauria; CRUZ E TUCCI, José Rogério. Constituição de 1988 e processo. São Paulo: Saraiva, 1989.

VIOLLET, Paul. Les établissements de Saint Louis. Paris: Librairie Renouard, 1881, t. 1, p. 218-219. Disponível em: $<$ http://gallica.bnf.fr/ark:/12148/bpt6k5493358m.r=Les+\%C3\%A9tablissements+Saint+Lo uis.langPT>. Acesso em: 25 out. 2001.

WAMBIER, Luiz Rodrigues; VASCONCELOS, Rita de Cássia Corrêa de. Sobre a repercussão geral e os recursos especiais repetitivos, e seus reflexos nos processos coletivos. Revista dos Tribunais, São Paulo, ano 98, v. 882, abr. 2009.

\section{LEGISLAÇÃo}

BRASIL. Constituição da República dos Estados Unidos do Brasil (de 16 de julho de 1934). Disponível em: <http://www.planalto.gov.br/ccivil_03/Constituicao/Constituicao34.htm>. Acesso em: $1^{\text {o }}$ set. 2010. 
BRASIL. Constituição da República dos Estados Unidos do Brasil (de 24 de fevereiro de 1891). Disponível em: <http://www.planalto.gov.br/ccivil_03/Constituicao/Constituicao91.htm>. Acesso em: 25 ago. 2010.

Constituição da República Federativa do Brasil de 1967. Disponível em: $<$ http://www.planalto.gov.br/ccivil_03/Constituicao/Constituicao67.htm>. Acesso em: 13 out. 2010.

- Constituição da República Federativa do Brasil de 1988. Disponível em: <http://www.planalto.gov.br/ccivil_03/Constituicao/Constituiçao.htm>. Acesso em: 10 out. 2010.

- Constituição dos Estados Unidos do Brasil (de 10 de novembro de 1937). Disponível em: <http://www.planalto.gov.br/ccivil_03/Constituicao/Constituicao37.htm>. Acesso em: $1^{\circ}$ set. 2010.

- Constituição dos Estados Unidos do Brasil (de 18 de setembro de 1946). Disponível em: <http://www.planalto.gov.br/ccivil_03/Constituicao/Constituicao46.htm>. Acesso em: 08 set. 2010.

. Constituição Política do Império do Brazil (de 25 de março de 1824). Disponível em: <http://www.planalto.gov.br/ccivil_03/Constituicao/Constituicao24.htm>. Acesso em: 25 de ago. 2010.

- Decreto n. 737, de 25 de novembro de 1950. Disponível em: <http://www.planalto.gov.br/ccivil_03/decreto/Historicos/DIM/DIM737.htm>. Acesso em: 25 ago. 2010.

. Decreto-Lei n. 5.452, de $1^{\circ}$ de maio de 1943. Disponível em: $<$ http://www.planalto.gov.br/ccivil_03/Decreto-Lei/Del5452.htm>. Acesso em: $1^{\text {o }}$ set. 2010.

- Decreto-Lei n. 8.737, de 19 de janeiro de 1946. Disponível em: <http://www.planalto.gov.br/ccivil_03/Decreto-Lei/Del8737.htm>. Acesso em: $1^{\text {o }}$ set. 2010.

Emenda Constitucional n. 1, de 17 de outubro de 1969. Disponível em: $<$ http://www.planalto.gov.br/ccivil_03/Constituicao/Emendas/Emc_anterior1988/emc0169.htm>. Acesso em: 13 out. 2010.

- Lei n. 861, de outubro de 1949. Disponível em: <http://www.planalto.gov.br/ccivil_03/Leis/L0861.htm>. Acesso em: 8 set. 2010.

Medida provisória n. 2.180-35, de 24 de agosto de 2001. Disponível em: <https://www.planalto.gov.br/ccivil_03/MPV/2180-35.htm>. Acesso em: 14 dez. 2010. 
CÂMARA DOS DEPUTADOS. Comissão de Justiça e Cidadania. Projeto de Lei n. 6.648, de 2006. Disponível em: <http://www.camara.gov.br/sileg/integras/399380.pdf>. Acesso em: 01 dez. 2010.

. Projeto de Lei e Outras Proposições. PL-168/1999. Disponível em: <http://www.camara.gov.br/sileg/Prop_Detalhe.asp?id=15118>. Acesso em: 23 set. 2010.

. Projeto de Lei e Outras Proposições. PL-3267/2000. Disponível em: <http://www.camara.gov.br/sileg/Prop_Detalhe.asp?id=19377>. Acesso em: 23 set. 2010.

DE JURE. Disponível em: <http://dejure.org/gesetze/ZPO/543.html>. Acesso em: 13 out. 2010.

MINISTÉRIO DA EDUCAÇÃO. Disponível $<$ http://machado.mec.gov.br/index.php?option=com_content\&task=view\&id=166\&Itemid $=173>$. Acesso em: 23 set. 2010 .

MINISTÉRIO DA JUSTIÇA. Reforma do Judiciário. Pacto Republicano. Disponível em: <http://portal.mj.gov.br/data/Pages/MJ8E452D90ITEMID87257F2711D34EE1930A4DC3 3A8DF216PTBRIE.htm>. Acesso em: $01 \mathrm{dez} 2010$.

SENADO FEDERAL. Decreto n. 1637, de 5 de janeiro de 1907. Disponível em: $<$ http://www6.senado.gov.br/legislacao/ListaPublicacoes.action?id=55323\&tipoDocument $\mathrm{o}=$ DEC\&tipoTexto $=$ PUB $>$.

SENADO FEDERAL. Disponível em: <http://www.senado.gov.br>.

Decreto n. 510, de 22 de junho de 1890. Disponível em: <http://www6.senado.gov.br/legislacao/ListaPublicacoes.action?id=91702>. Acesso em: 20 ago. 2010.

Decreto n. 848, de 11 de outubro de 1890. Disponível em: <http://www6.senado.gov.br/legislacao/ListaPublicacoes.action?id=66054>. Acesso em: $1^{\circ}$ set. 2010.

- Decreto-Lei n. 1.237, de 02 de maio de 1939. Disponível em: $<$ http://www6.senado.gov.br/legislacao/ListaPublicacoes.action?id=8115>. Acesso em: $1^{\circ}$ set. 2010.

Lei de 20 de outubro de 1823. Disponível em: <http://www6.senado.gov.br/legislacao/ListaPublicacoes.action?id=84601>. Acesso em: 25 de ago. 2010.

- Parecer n. 75, de 2006. Disponível em: $<$ http://www.senado.gov.br/atividade/materia/getPDF.asp?t=40132>. Acesso em: $01 \mathrm{dez}$. 2010. 
SENADO FEDERAL. Portal Atividade Legislativa. Comissões Mistas. Disponível em: $<$ http://www.senado.gov.br/atividade/comissoes/default.asp?origem $=\mathrm{CN}>$. Acesso em: 23 set. 2010.

- Projetos e Matérias Legislativas. Disponível em: $<$ http://www.senado.gov.br/sf/atividade/materia/detalhes.asp?p_cod_mate=48280 $>$.. Acesso em: 27 dez. 2010.

SUPREME COURT OF THE U.S. - RULES. Disponível em: $<$ http://www.law.cornell.edu/rules/supct/10.html>. Acesso em: 20 out. 2010.

SUPREMO TRIBUNAL FEDERAL. Diário da Justiça. Disponível em: $<$ http://www.stf.jus.br/arquivo/biblioteca/PastasMinistros/CarlosVelloso/Discursos/Proferi dos/042.pdf>. Acesso em: $1^{\text {o }}$ set. 2010.

. Disponível em: <http://redir.stf.jus.br>. Acesso em: 10 out. 2010.

TRIBUNAL REGIONAL DO TRABALHO 1a REGIÃO. Decreto n. 6.596 - de 12 de dezembro de $1940 . \quad$ Disponível em: $<$ http://portal2.trtrio.gov.br:7777/portal/page?_pageid=73,5714538\&_dad=portal\&_schem $\mathrm{a}=$ PORTAL $>$. Acesso em: $1^{\mathrm{o}}$ set. 2010.

TRIBUNAL SUPERIOR DO TRABALHO. Dados Demonstrativos. Disponível em: <http://www.tst.jus.br/Sseest/RGJT/Rel2009/TST2009/TST2008.pdf>. Acesso em: 19 out. 2010.

. Disponível em: <http://www.tst.jus.br>.

Ministros do TST. Disponível em: <http://www.tst.jus.br/ASCS/ministro.html>. Acesso em: 19 out. 2010.

Municípios Jurisdicionados. Disponível em: <http://www.tst.jus.br/tst/iframe.php?url=http://www.tst.jus.br/Sseest/VT/Munic2005.htm >. Acesso em: 08 set. 2010.

Processos.

Disponível

em:

<http://www.tst.jus.br/Sseest/JT1941/TST1941/TST1941.htm>. Acesso em: 19 out. 2010.

. Relatório Geral da Justiça do Trabalho - 2009. Disponível em: <http://www.tst.gov.br/Sseest/RGJT/Rel2009/JT2009/rel2009.pdf>. Acesso em: 19 out. 2010.

\footnotetext{
Resolução Administrativa n. 1272. .Disponível em: <http://www.tst.jus.br/DGCJ/IndiceResolucoes/ResAdm/1272.html>. Acesso em: 23 set. 2010 .
} 
TRIBUNAL SUPERIOR DO TRABALHO. Resolução Administrativa n. 1360, de 13 de outubro de $2009 . \quad$ Disponível em: <http://www.tst.jus.br/DGCJ/IndiceResolucoes/ResAdm/1360.pdf>. Acesso em: 17 out. 2010.

Resolução Administrativa n. 1360, de 13 de outubro de 2009. Disponível em: <http://www.tst.jus.br/DGCJ/IndiceResolucoes/ResAdm/1360.pdf>. Acesso em: 10 jan. 2010 .

Súmulas da Jurisprudência Uniforme do Tribunal Superior do Trabalho. Disponível em: <http://www.tst.jus.br/jurisprudencia/Livro_Jurisprud/livro_html_atual.html\#Sumulas>. Acesso em: 08 set. 2010.

- Temas não Convertidos em Orientação Jurisprudencial. Disponível em: $<$ http://www.tst.gov.br/jurisprudencia/n_temas_nao_convertidos_oj.html>. Acesso em: 08 set. 2010. 